\title{
OKLAHOMA, A SUMMARY OF ACTIVITIES \\ OF THE U.S. GEOLOGICAL SURVEY, WATER RESOURCES DIVISION, IN FISCAL YEARS 1988-90
}

\author{
Compiled by \\ John S. Havens
}

U.S. GEOLOGICAL SURVEY

Open-File Report 91-492

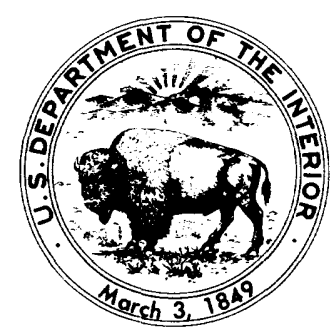

Oklahoma City, Oklahoma

1991 


\section{U.S. DEPARTMENT OF THE INTERIOR MANUEL LUJAN, JR., Secretary U.S. GEOLOGICAL SURVEY}

Dallas L. Peck, Director

For additional information write to:

District Chief

U.S. Geological Survey

Water Resources Division 202 NW $66^{t h}$ St., Bldg. 7

Oklahoma City, OK 73116
Copies of this report can be purchased from:

Books and Open-File Reports

U.S. Geological Survey

Federal Center

Box 25425

Denver, Colorado 80225 


\section{CONTENTS}

Page

Abstract . . . . . . . . . . . . . . . . . . . . . . . . . . 1

A message from the District Chief . . . . . . . . . . . . . . . . . . . . . . . 1

U.S. Geological Survey origin . . . . . . . . . . . . . . . . . . . . . . . . . 2

Water resources mission of the U.S. Geological Survey . . . . . . . . . . . . . . 3

Oklahoma District organization chart . . . . . . . . . . . . . . . . . . . 4

Types of investigations and sources of funding for Oklahoma in 1988-90 . . . . . . . 5

List of cooperators . . . . . . . . . . . . . . . . . . . . . . . . . . . . . 6

Water conditions in Oklahoma . . . . . . . . . . . . . . . . . . . . . . . 7

Summary of projects (short titles) . . . . . . . . . . . . . . . . . . . . . . . 9

OK001-Surface-water stations . . . . . . . . . . . . . . . . . . . . . . 9

OK002--Ground-water stations . . . . . . . . . . . . . . . . . . . . . . 9

OK003-Water-quality stations . . . . . . . . . . . . . . . . . . 10

OK004-Sediment stations . . . . . . . . . . . . . . . . . . 10

OK005-National trends network . . . . . . . . . . . . . . . . . . . . . 11

OK006-FEMA flood insurance studies . . . . . . . . . . . . . . . . . . 11

OK007-Oklahoma water-use data system . . . . . . . . . . . . . . . . . 11

OK044-Water-resources monitoring, eastern Oklahoma coal field . . . . . . . 12

OK049-Coal Creek Basin . . . . . . . . . . . . . . . . . . . . . . . 12

OK057-Digital model, Antlers aquifer . . . . . . . . . . . . . . . . . . 13

OK058-Geohydrology, Roubidoux aquifer . . . . . . . . . . . . . . . 13

OK062-Central Midwest Regional Aquifer System Analysis . . . . . . . . . 14

OK065--Geohydrology, North Canadian River, Oklahoma City to Eufaula Lake . 1.4

OK068-Geochemistry, Tar Creek lead-zinc area . . . . . . . . . . . . . . 15

OK069-Inventory of Oklahoma springs . . . . . . . . . . . . . . . . . . 15

OK070-Digital model, Roubidoux aquifer . . . . . . . . . . . . . . 16

OK072-Geohydrology, Cimarron River, Kansas State line to Guthrie, Oklahoma 16

OK073-Rush Springs aquifer . . . . . . . . . . . . . . . . . 17

OK074-Roubidoux aquifer, vicinity of Picher mining field . . . . . . . . . . 18

OK075-Limnology, coal-mine ponds, eastern Oklahoma . . . . . . . . . . . 18 
OK076-Projected water use, Antlers aquifer . . . . . . . . . . . . . . . . 19

OK079-Streamflow statistics, Oklahoma streams . . . . . . . . . . . . . . 20

OK080-Hydrogeologic characteristics, shaley formations . . . . . . . . . . . 20

OK081-Hydrogeology, Blaine aquifer . . . . . . . . . . . . . . . . . . . 21

OK082-Hydrogeology, water quality, Garber-Wellington, central Oklahoma 22

OK084-Hydrogeology, Chickasaw National Recreation Area . . . . . . . . . 23

OK085-Analysis, ground-water systems using geographic information system $\quad 23$

OK086-Altus AFB IRP study: RI/FS Stage 1 . . . . . . . . . . . . . . . 24

OK089-Curriculum development, computer sciences, Langston University . . . 25

OK090-Water-level monitoring, High Plains aquifer . . . . . . . . . . . . . 25

OK091-Naturally occurring toxic substances, Central Oklahoma aquifer . . . . 26

OK092-Impact of oil refinery products and wastes, Cyril _ . . . . . . . . . 26

OK093-Automated quality assurance . . . . . . . . . . . . . . . . 27

OK094-Ground-water recharge demonstration projects . . . . . . . . . . . 28

OK095-Ground water, Wellston, Oklahoma . . . . . . . . . . . . . . . . 29

OK096-Hydrology, Byrds Mill Spring . . . . . . . . . . . . . . . . 29

OK097-Sac and Fox ground-water study . . . . . . . . . . . . . . . . . 30

Other District activities in support of the State's water programs . . . . . . . . . 31

Bibliography of Oklahoma hydrology . . . . . . . . . . . . . . . . . . 32

Sources of U.S. Geological Survey publications and books . . . . . . . . . . . . 67

\section{TABLES}

Table 1. Ground-water sites included in the mass measurement network . . . . 69

2. Continuous and partial-record ground-water sites . . . . . . . . . . 92 


\section{FIGURES}

Page

Figure 1-8. Maps showing:

1. Areas for which reconnaissance hydrologic studies have been made . . 94

2. Average annual runoff in Oklahoma for 1970-79 . . . . . . . . . . . 95

3. Location of principal aquifers in Oklahoma . . . . . . . . . . . . . 96

4. Location of continuous-record surface-water stations, water year $1990 \quad$ • 97

5. Location of partial-record surface-water stations, water year 1990 . . . 98

6. Location of water-quality stations, water year 1990 . . . . . . . . . . 99

7. Locations of sediment sampling sites . . . . . . . . . . . . . . . 100

8. Locations of water wells measured continuously, monthly, or quarterly . 101 


\title{
OKLAHOMA, A SUMMARY OF ACTIVITIES OF THE U.S. GEOLOGICAL SURVEY, WATER RESOURCES DIVISION, IN FISCAL YEARS 1988-90
}

\author{
Compiled by \\ John S. Havens
}

\begin{abstract}
This report summarizes the activities of the Oklahoma District, Water Resources Division, U.S. Geological Survey, for fiscal years 1988-90. Included are summary statements of current and recently completed projects, an updated bibliography of reports dealing with Oklahoma hydrology, a table of ground-water sites included in the mass-measurement network, and a listing of continuous and partial-record ground-water sites.
\end{abstract}

\section{A MESSAGE FROM THE DISTRICT CHIEF}

The U.S. Geological Survey historically has worked to fulfill its principal mission of appraising the nation's water resources through scientifically designed data-collection and investigative programs managed at the District level. This provides ready access by State and local governments to valuable information on national water issues, but also allows Districts to concentrate on relevant State and local needs.

Past reports on topics such as ground water in the High Plains, flood frequency of Oklahoma streams, water quality of the Garber-Wellington aquifer, and potential water supplies from the alluvial and terrace aquifers of the North Canadian River have provided information beneficial both to the Nation and residents of Oklahoma. The focus of water-resources studies has changed as awareness of the vulnerability of water resources to contamination has joined long-standing concerns,such as long-term water supplies for all needs and prediction of and protection from catastrophic flooding.

Data-collection activities and investigative projects will enable the Oklahoma District of the U.S. Geological Survey to meet the challenge and opportunity of providing needed water-resources information in the future.

\author{
Kathy D. Peter \\ District Chief \\ U.S. Geological Survey \\ Oklahoma City, Okla.
}




\section{U.S. GEOLOGICAL SURVEY ORIGIN}

The U.S. Geological Survey was established by an act of Congress on March 3, 1879 to provide a permanent Federal agency to conduct the systematic and scientific "classification of the public land, and examination of the geological structure, mineral resources, and products of national domain." An integral part of that original mission includes publishing and dissemination the earth-science information needed to understand, to plan the use of, and to manage the Nation's energy, land, mineral, and water resources.

Since 1879, the research and fact-finding role of the USGS has grown and been modified to meet the changing needs of the Nation it serves. As part of that evolution, the USGS has become the Federal Government's largest earth-science research agency, the Nation's largest civilian map-making agency, the primary source of data on the Nation's surfaceand ground-water resources, and the employer of the largest number of professional earth scientists. Today's programs serve a diversity of needs and users. Programs include:

- Conducting detailed assessments of the energy and mineral potential of the $\mathrm{Na}$ tion's land and offshore areas.

- Investigating and issuing warning of earthquakes, volcanic eruptions, landslides, and other geologic and hydrologic hazards.

- Conducting research on the geologic structure of the Nation.

- Studying the geologic features, structure, processes, and history of the other planets of our solar system.

- Conducting topographic surveys of the Nation and preparing topographic and thematic maps and related cartographic products.

- Developing and producing digital cartographic data bases and products.

- Collecting data on a routine basis to determining the quantity, quality, and use of surface and ground water.

- Conducting water-resource appraisals in order to describe the consequences of alternative plans for developing land and water resources.

- Conducting research in hydraulics and hydrology, and coordinating all Federal water-data acquisition.

- Using remotely sensed data to develop new cartographic, geologic, and hydrologic research techniques for natural resources planning and management.

- Providing earth-science information through an extensive publications program and a network of public access points.

Along with its continuing commitment to meet the growing and changing earth-science needs of the Nation, the USGS remains dedicated to its original mission to collect, analyze, interpret, publish, and disseminate information about the natural resources of the Nationproviding "Earth Science in the Public Service." 


\section{WATER RESOURCES MISSION OF THE U.S. GEOLOGICAL SURVEY}

The water resources mission of the U.S. Geological Survey is to provide the hydrologic information needed by others to help manage the Nation's water resources. To accomplish its mission, the Survey, in cooperation with State and local governments and other Federal agencies:

- Collects data on a systematic basis to determine the quantity, quality, and use of surface and ground water, and the quality of precipitation.

- Conducts water-resources investigations and assessments at national, State, and local scales, characterizes water-resources conditions, and provides the capability to predict the impact on the resource of managerial actions, proposed development plans, and natural phenomena.

- Conducts basic and problem-oriented hydrologic and water-related research that is likely to produce knowledge useful for the resolution of water-resources problems facing the State, regions, and Nation.

- Acquires information useful in predicting and delineating water-related natural hazards from flooding, volcanoes, mudflows, and land subsidence.

- Coordinates the activities of all Federal agencies in the acquisition of water data, and operates water information centers.

- Disseminates data and the results of investigations through reports, maps, and other forms of public release.

- Provides scientific and technical assistance in hydrology to other Federal agencies, to State and local agencies, to licensees of the Federal Energy Regulatory Commission, and, on behalf of the U.S. Department of State, to international agencies.

- Administers the provisions of the Water Resources Research Act of 1984, which include the State Water Resources Research Institute Program (Section 104) and the Water Resources Research Grant Program (Section 105). 


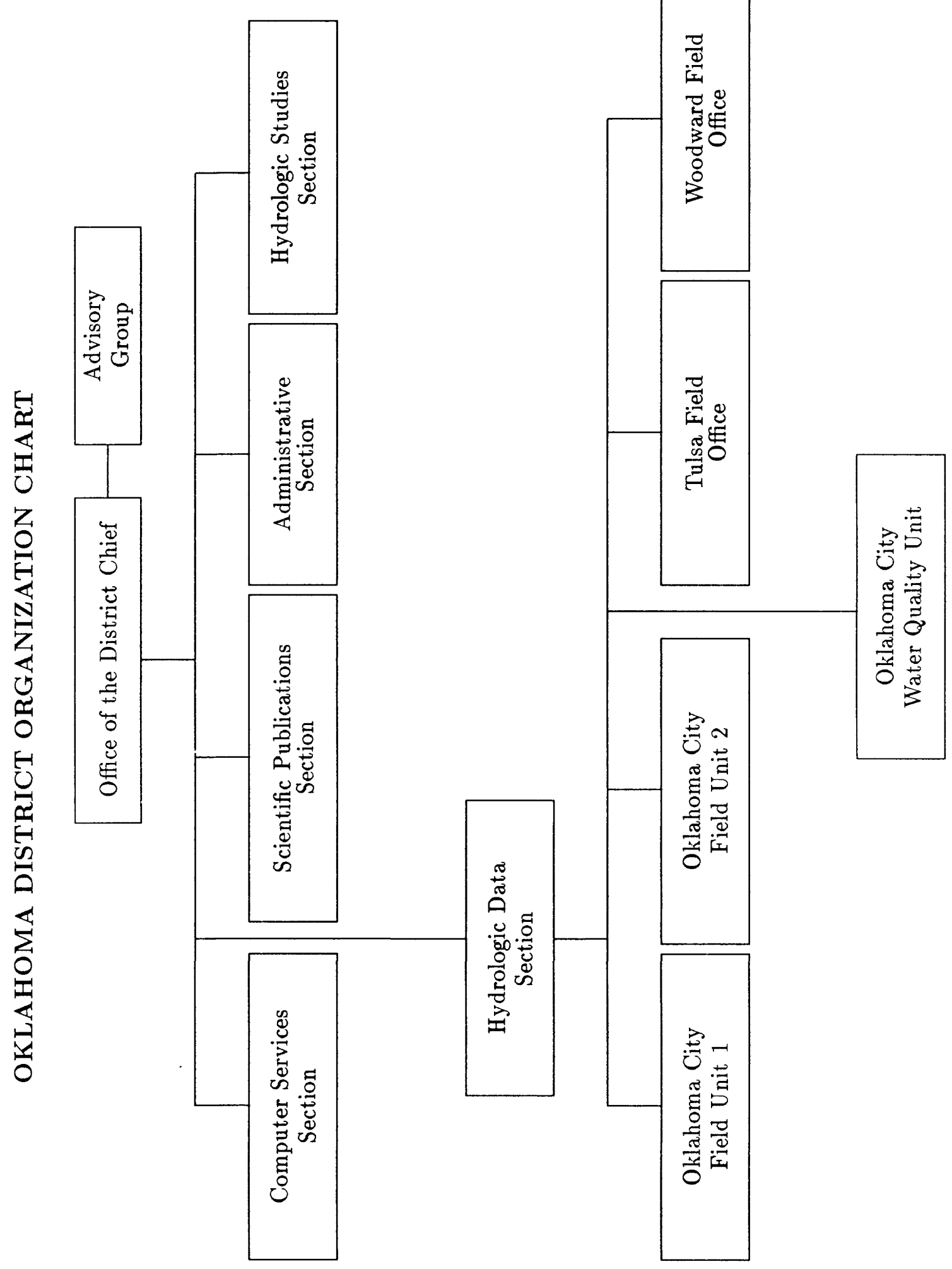




\section{TYPES OF INVESTIGATIONS AND SOURCES OF FUNDING FOR OKLAHOMA IN 1988-90}

Four broad categories of investigations are conducted in Oklahoma to obtain the information needed by managers and planners for the solution or alleviation of water problems in the State. These categories are: (1) Areal studies involving the appraisal of groundwater resources and river basins, (2) hydrologic data collection involving the statewide surface-water, ground-water, and quality-of-water monitoring programs, (3) research involving special studies that improve our understanding of hydrology, and (4) administration of programs involving the collection of data for national programs. The diagrams below show these investigations, expressed as a percentage of the District's total work for fiscal years 1988-90.

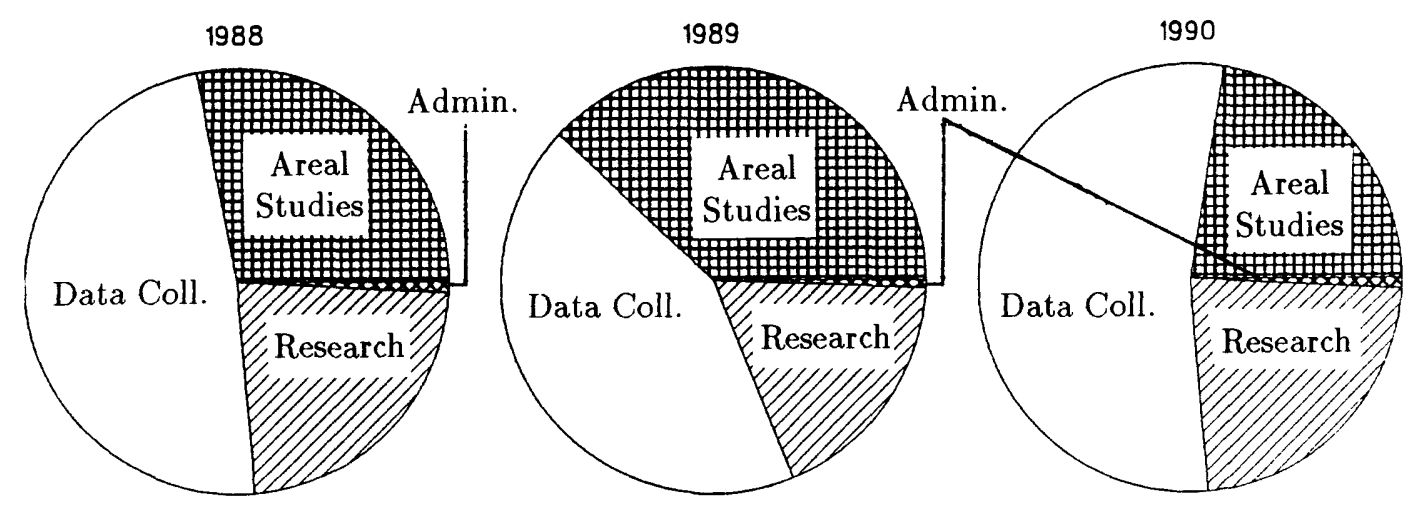

The investigations shown above are supported by services and funds from three basic programs: (1) Cooperative programs with 50 percent of the funds provided by State and local agencies and the remaining 50 percent by Federal funds, (2) Federal programs with funds appropriated directly to the U.S. Geological Survey, and (3) other Federal agency programs (OFA) supported entirely by other Federal agencies. In fiscal year 1988, the financial support for these three programs in Oklahoma was about $\$ 4,141,000$; in 1989 , about $\$ 4,917,000$; and in 1990 , about $\$ 4,220,000$. The distribution is shown below.
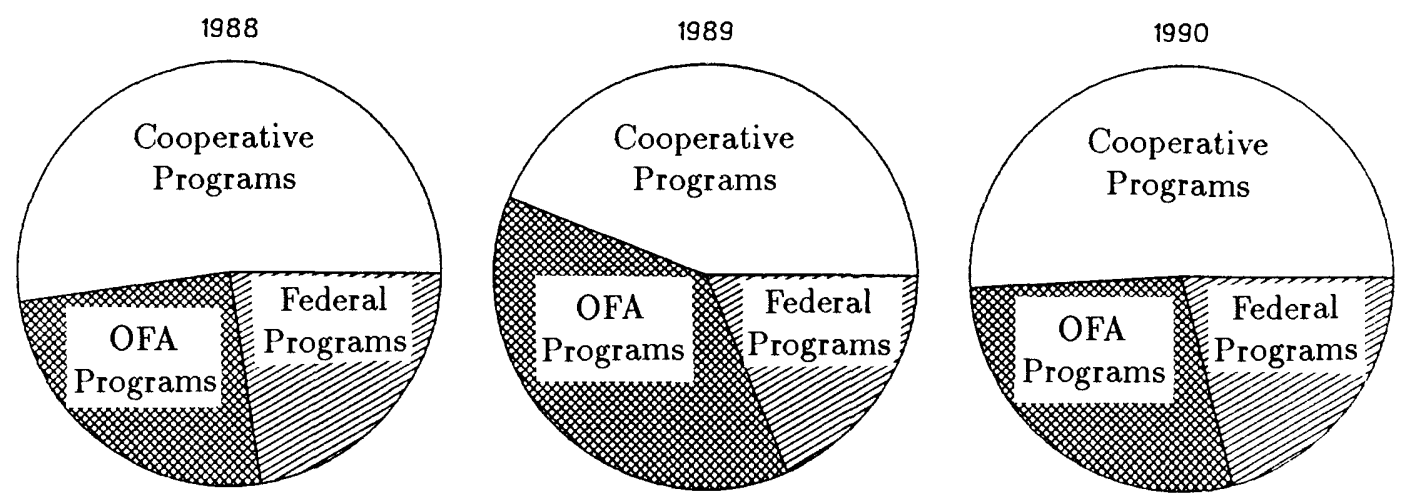


\section{LIST OF COOPERATORS}

The following table lists State, local, and other Federal agencies that supported waterresources investigations in cooperation with the U.S. Geological Survey during fiscal years 1988-90:

State Agencies

Oklahoma Conservation Commission

Oklahoma Department of Transportation

Oklahoma Geological Survey

Oklahoma Pollution Control Coordinating Board

Oklahoma State Department of Health

Oklahoma Water Resources Board

\section{Local Agencies}

Association of Central Oklahoma Governments

City of Ada

City of Altus

City of Edmond

City of Lawton

City of Norman

City of Oklahoma City

City of Tulsa

Central Oklahoma Master Conservancy District

Ft. Cobb Reservoir Master Conservancy District

Foss Reservoir Master Conservancy District

Grand River Dam Authority

Lugert-Altus Irrigation District

Mountain Park Master Conservancy District

Oklahoma Gas and Electric Company

Town of Wellston

\section{Federal Agencies}

Bureau of Indian Affairs

Federal Emergency Management Agency

National Park Service

U.S. Air Force

U.S. Army Corps of Engineers

U.S. Bureau of Reclamation 


\section{WATER CONDITIONS IN OKLAHOMA}

Large variations in streamflow characterize hydrologic conditions in Oklahoma. In the extreme southeastern part of the State, mean annual precipitation exceeds 52 inches and mean annual runoff exceeds 20 inches. In the southeast, stream channels are deeply incised in mountainous terrain and streamflow generally is perennial. In the extreme northwestern part of the Panhandle, mean annual precipitation is less than 16 inches and mean annual runoff is less than 0.1 inch. In northwestern Oklahoma, streams generally have shallow, ill-defined channels and ephemeral flow.

\section{Water Year 1988}

Precipitation data from monthly reports of the National Weather Service, averaged over the State, indicate that monthly precipitation was greater-than-normal during November, December, January, March, April, July, and September of water year 1988. Precipitation was less than normal during February, May, June, and August

In spite of the greater-than-normal streamflow for the year, drought conditions existed during some months. Streamflow was much less than normal in all streams during May and June, except in south-central Oklahoma. Streamflow continued to be below normal during July and August, with near-normal flow in September in the north-central and northeast; in the southwest September stream flow was much greater than normal. In the southeast, streamflow was less than normal in July and September but greater than normal in August. In the far southeast, stream flow was greater than normal in July and August, and less than normal in September.

\section{Water Year 1989}

Precipitation data from monthly reports of the National Weather Service, averaged over the State, indicate that monthly precipitation was above normal during November, January, February, March, May, June, August, and September of water year 1989. Precipitation for June was much greater than normal; total rainfall in Oklahoma City for June was 14.47 inches, the most since record keeping began in Oklahoma City in 1890. Monthly precipitation was well below normal during October and April; April was the driest in 98 years. Precipitation in December and July was about average.

Streamflow in eastern Oklahoma was far below normal in all streams during October and April. Streamflow was above normal the remainder of the year. In central Oklahoma, streamflow was below normal during mid-April through mid-May and normal in February, March, and June through September. In western Oklahoma, streamflow generally was above normal from mid-May through September. Selected sites statewide show above normal streamflow from June through September. In spite of the month-to-month variation, streamflow on an annual basis was about normal, with all annual peak flow in the medium flow range. However, some flooding occurred during June in central Oklahoma.

\section{Water Year 1990}

Precipitation data from monthly reports of the Oklahoma Climatological Servey, averaged over the State, indicate that monthly precipitation was below normal during October through December, June, and August, normal during July, and above normal during 
September of water year 1990. However, precipitation for January through May was much greater than normal; since record keeping began throughout the State in 1892, the statewide average accumulation of 25.75 inches for January through May 1990 was exceeded only by 25.94 inches in 1957. In some parts of the southeast, the total accumulation was 34 inches above the long-term mean. It was the wettest January-April on record. The extremely wet late winter and early spring made it the seventh wettest year on record.

Streamflow in central, eastern, southcentral, and southeastern Oklahoma was above normal in all streams during January, February, and September. During March, April, and May, streamflow was far above normal, with many streams attaining record or nearrecord peak flows at the end of April and beginning of May. Severe flooding in these areas equalled or exceeded the serious flooding of April-June 1957. Streamflow was about normal the remainder of the water year except in the southeast and east, where it was below normal from October through December. Annual streamflow was far above normal in these areas of Oklahoma, setting a record for annual flow at many sites.

In southwestern Oklahoma streamflow was above normal in January through May and in September, and normal the rest of the year. In northcentral Oklahoma, streamflow was above normal in October, January, March, and April; normal during November, December, and February; and below normal the rest of the year. In northwestern Oklahoma, streamflow generally was above normal from October through May and below normal the remainder of the year. Annual streamflow was about normal in these areas of Oklahoma.

Storage in all major reservoirs in the State, with a combined conservation storage capacity of over 13 million acre-feet, averaged over 99 percent at the end of May. The flood-crest elevation was at or above the elevation of the 100 percent flood-control pool in many reservoirs. 


\section{SUMMARY OF PROJECTS}

Title: SURFACE-WATER STATIONS

Leader: Blazs, Robert L.

Number: OK001

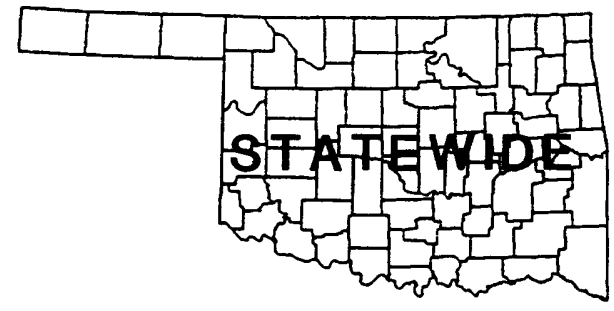

Problem: Surface-water information is needed for purposes of surveillance, planning, design, hazard warning, operation, and management, in water-related fields such as water supply, hydroelectric power, flood control, irrigation, bridge and culvert design, wildlife management, pollution abatement, flood-plain management, and water resources development. To provide this information an appropriate data base is necessary.

Objective: A. To collect surface-water data for: 1) Assessment of water resources, 2) operation of reservoirs or industries, 3) forecasting, 4) disposal of wastes and pollution controls, 5) discharge data to accompany water-quality measurements, 6) compact and legal requirements, and 7) research or special studies. B. To collect data for analytical studies of the statistical properties of, and trends in, the occurrence of surface water.

Progress: Surface-water data were collected at 188 active sites (fig. 4 and 5): 139 streamgaging stations (continuous-discharge records), 32 lake and reservoir gages, 6 dual-digital gages (synchronous stage-rainfall with discharge hydrograph data only), 5 continuous stageonly gages, 2 continuous stage with high-flow discharge data only, and 1 miscellaneous discharge data site. In addition, continuous records of discharge were computed and published from 3 gaging stations operated and maintained by the U.S. Army Corps of Engineers.

Cooperating Agencies: Local, State, and Federal agencies in Oklahoma.

Title: GROUND-WATER STATIONS

Leader: Goemaat, Robert L.

Number: OK002

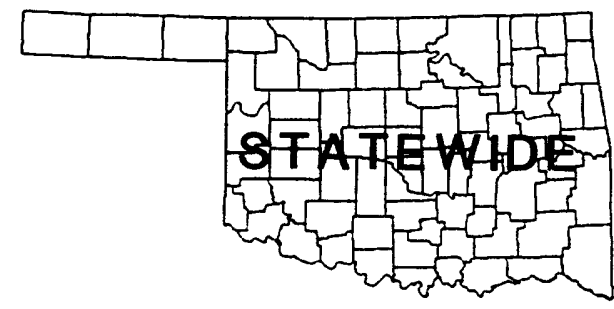

Problem: Long-term water-level records are needed to evaluate the effects of climatic variations on the recharge to and discharge from the ground-water systems, to provide a data base from which to measure the effects of development, and to provide data for management of the resource.

Objective: A. To collect water-level data to provide long-term records of the general response of the hydrologic system to natural climatic variations and induced stresses. B. To provide a data base against which the short-term records acquired in areal studies can be analyzed.

Progress: During the 1988-89 fiscal years, water levels were measured in 1,058 wells; continuous water levels were monitored at 29 sites; and yearly, monthly, or quarterly measurements were made at 1,029 other sites. During the 1990 fiscal year, water levels were 
measured in 33 wells; continuous water levels were monitored at 29 sites and yearly, monthly, or quarterly measurements were made at 4 other sites (fig. 8).

Cooperating Agency: Oklahoma Water Resources Board

Title: WATER-QUALITY STATIONS

Leader: Kurklin, Joanne K.

Number: OK003

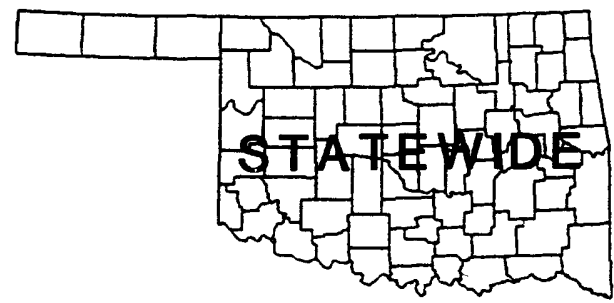

Problem: Water-resource planning and water-quality assessment require a nationwide base level of relatively standardized information. For intelligent planning and realistic assessment of the water resource, the chemical and physical quality of the rivers and streams must be defined and monitored.

Objective: To provide a national bank of water-quality data for broad federal planning and action programs and to provide data for federal management of interstate waters.

Progress: Water-quality data were collected at 46 active sites; of these, 12 were equipped with minimonitors for collection of continuous data. The sites locations are shown on figure 6 .

Cooperating Agencies: Oklahoma Water Resources Board, Oklahoma State Department of Health.

Title: SEDIMENT STATIONS

Leader: Kurklin, Joanne K.

Number: OK004

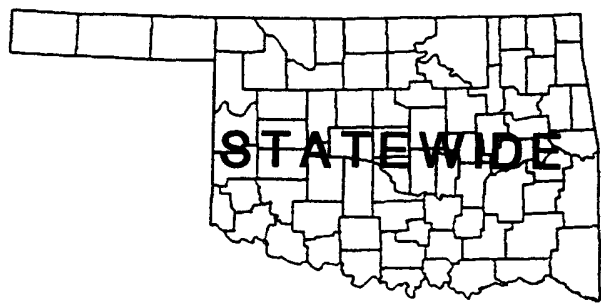

Problem: Water-resource planning and water-quality assessment require a nationwide base level of relatively standardized information. For intelligent planning and realistic assessment of water resources, sediment concentrations and discharges in rivers and streams must be defined and monitored.

Objective: To provide a national bank of sediment data for use in broad federal and state planning and action programs and to provide data for federal management of interstate and international waters.

Progress: Sediment data are collected presently at 34 sites. Figure 7 shows the location of each site. 
Cooperating Agencies: Local, State, and Federal agencies in Oklahoma.

Title: NATIONAL TRENDS NETWORK FOR MONITORING

Leader: Kurklin, Joanne K.

Number: OK005

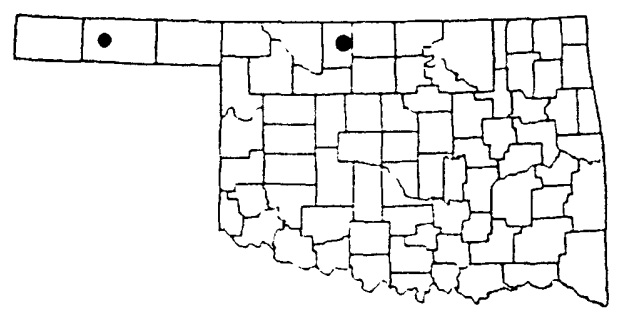

Problem: To establish long-term monitoring stations to detect and measure levels of atmospheric deposition.

Objective: To determine variations in atmospheric depositions that occur on a weekto-week basis. To collect wet and dry deposition products for analysis of elements and compounds that can contribute to chemical composition of surface waters.

Progress: Two active continuous sites are maintained.

Title: FEMA FLOOD INSURANCE STUDIES BY LIMITED DETAIL METHODOLOGIES

Leader: Tortorelli, Robert L

Number: OK006

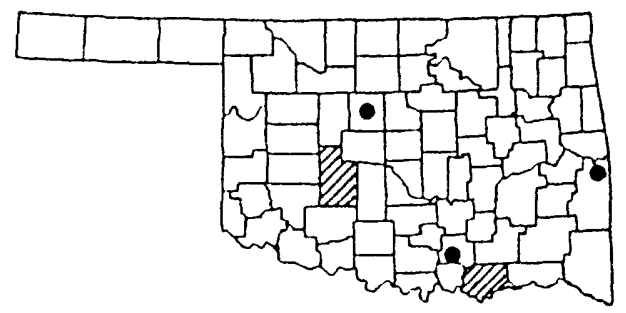

Problem: The 100-year recurrence-interval flood potential needs to be determined for the purposes of the National Flood Insurance Program in many populated areas. Because of limited funding, alternative ways of determining the 100-year profile and boundaries are being used-limited detail methodologies.

Objective: The 100-year recurrence-interval flood will be published as inundation maps and flood profiles for: Bryan and Caddo Counties, and the towns of Dover, Pocola, and Tishomingo, Okla., by use of limited detail study (LDS) methods.

Progress: The Less Detailed Study/Flood Insurance Study (LDS/FIS) for Dover and Caddo County has been completed. Project is Completed.

Title: OKLAHOMA WATER-USE DATA SYSTEM

Leader: May, Jayne E.

Number: OK007

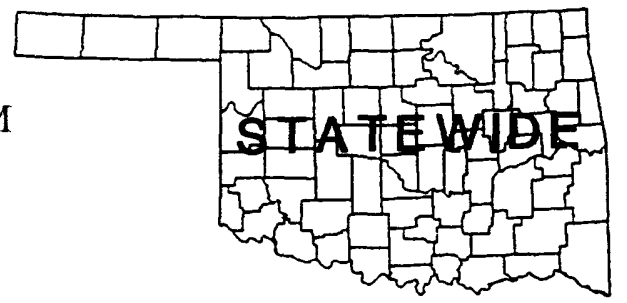

Problem: Water-use data that have been collected for the State of Oklahoma are presently distributed throughout many Federal, State, and local agencies. The data are in different formats and contain different bits of information that may make the data from one agency unusable by another agency. Future data collection is presently based on various agency 
needs that can render the data to be collected by one agency incompatible with another agency's needs.

Objective: To develop a comprehensive point-source water-use collection and management system for the State of Oklahoma.

Progress: We have begun populating the New Site-Specific Water-Use Data System with data collected from public suppliers. A paper was presented at the American Water Resources Association meeting in Tampa, Fla., entitled "Development of a withdrawal-point water-use data base in Oklahoma." We will continue to try to find funding for a full interpretive study using this information. Water-use data were collected and analyzed for two other District projects.

Cooperating Agency: Oklahoma Water Resources Board

Title: WATER-RESOURCES MONITORING IN THE EASTERN OKLAHOMA COAL FIELD

Leader: Blumer, Stephen $P$.

Number: OK044

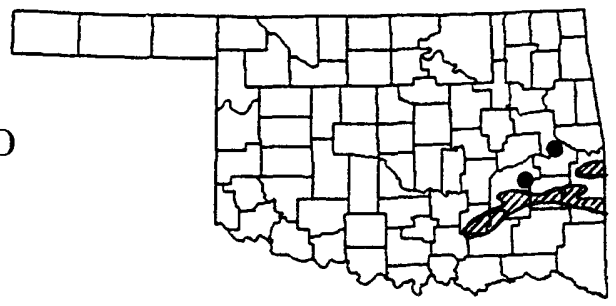

Problem: Strip mining coal in eastern Oklahoma may have adverse effects on the area's water resources. The principal adverse effect may be degradation by solution of minerals exposed by mining and increased sediment loads of streams. Mine dewatering, changes in land use, disposal of wastes, stream-channel realignment, and increased water use may significantly alter the existing hydrologic system on a regional basis, limit available supplies, and cause local and overall deterioration of the available water.

Objective: The objective of the program is to determine the characteristics of the regional hydrologic system and to detect and document changes in the system that may occur as the result of coal mining.

Progress: The project is completed. A data report containing all project data has been approved for release as Open-File Report (OFR 86-319). Interpretive report (Water-Resources Investigations Report) is in review.

Title: COAL CREEK BASIN, OK

Leader: Blumer, Stephen P.

Number: OK049

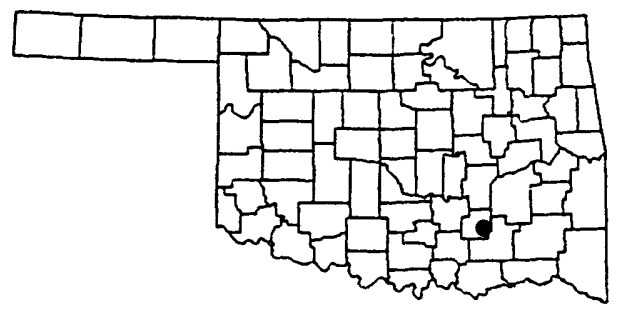

Problem: Coal underlying about 375,000 acres in the eastern Oklahoma coal field is Federally owned. The Bureau of Land Management is charged with the responsibility of assessing probable water-resource effects and reclamation capabilities of any area under Federal jurisdiction in which surface mining for coal might occur. None of the studies so far underway in Oklahoma's coal fields specifically addresses the problem of predicting effects on water 
resources of extracting coal by surface mining techniques. A study by the U.S. Geological Survey, in cooperation with the Bureau of Land Management, is underway.

Objective: The study's primary objective is to collect and interpret sufficient hydrologic data to predict and assess the effects of surface mining for coal and subsequent reclamation efforts on hydrologic characteristics. A secondary objective is collection of sufficient hydrologic data so that baseline hydrologic conditions can be defined and possible changes occurring after mining takes place can be documented.

Progress: Project is complete except report.

Title: DIGITAL MODEL OF THE ANTLERS AQUIFER, SOUTHEASTERN OKLAHOMA

Leader: Morton, Robert B.

Number: OK057

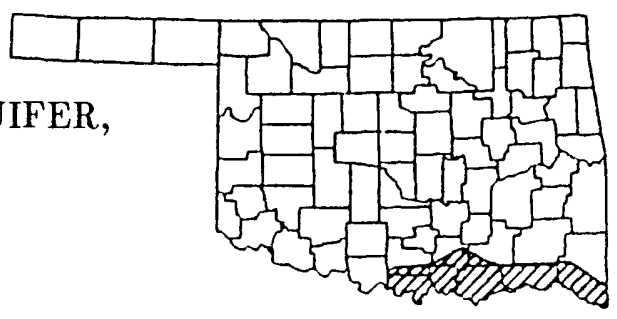

Problem: The future economy of southeastern Oklahoma is dependent largely upon wise utilization and management of the regions's water resources. A major source of water in this area is the Antlers aquifer, which underlies 4,400 square miles and contains about $31,600,000$ acre-feet of water having less than $1,000 \mathrm{mg} / \mathrm{l}$ dissolved solids. However, proper utilization and management of this resource cannot be achieved with the present knowledge of the hydrologic system.

Objective: To develop a more complete understanding of the hydrologic system than is presently known, to predict the effect of future withdrawals from the aquifer, and to aid in the management and utilization of the aquifer. These objectives will be achieved by the use of a digital flow model of the aquifer.

Progress: Final report has been written and is awaiting final approval.

Cooperating Agency: Oklahoma Geological Survey

Title: GEOHYDROLOGY OF THE ROUBIDOUX AQUIFER, NORTHEASTERN OKLAHOMA

Leader: Christenson, Scott C.

Number: OK058

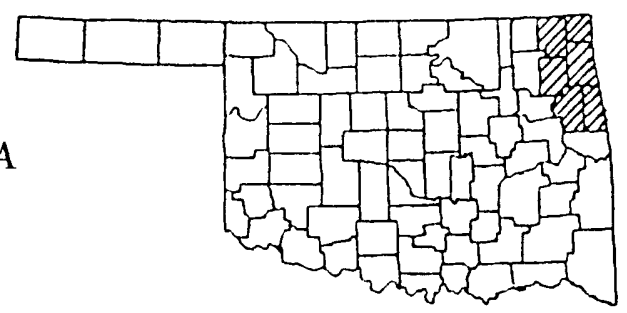

Problem: Maximum and orderly development of ground water from the Roubidoux aquifer requires an accurate knowledge of the quantity and quality of water available and the functioning of the hydrologic system; such information is not available now. Specific problems include: (1) Potential over-development of the aquifer in the vicinity of the City of Miami, (2) potential contamination of the aquifer by toxic waters from the abandoned zinc mines a few hundred feet above the aquifer, and (3) excessive amounts of naturally-occurring radium in water from the aquifer in some areas. 
Objective: To provide information on: (1) Availability of water from the aquifer and its suitability for municipal, domestic, and industrial supply, (2) extent of over-development and project the possible consequences of increasing stresses on the aquifer, (3) the hydrologic relationship between water in the aquifer and toxic waters in the abandoned zinc mines, and (4) extent and amount of radium in the water and its probable source.

Progress: The project is completed. A final report combining this project and project OK070 has been approved and released as Open-File Report $90-570$ pending publication by the cooperator.

Cooperating Agency: Oklahoma Geological Survey

Title: CENTRAL MIDWEST REGIONAL AQUIFER SYSTEM ANALYSIS IN OKLAHOMA

Leader: Christenson, Scott C.

Number: OK062

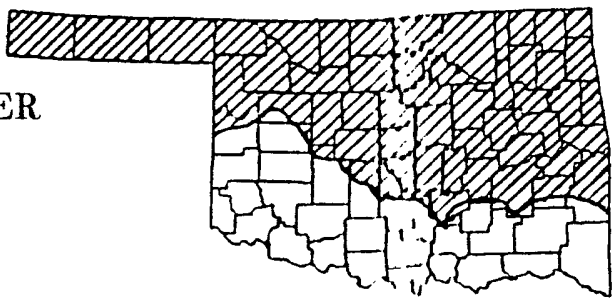

Problem: Mesozoic and Paleozoic formations are major sources of water supplies in some parts of Oklahoma. In other parts of the State these formations contain slightly saline to saturated brines. Some of those formations are oil and gas reservoirs and, at other locations, are storage reservoirs for industrial waste. A knowledge of the geohydrologic system is essential to determine the availability of ground water and to plan maximum and orderly development of this vital resource.

Objective: (1) Describe the hydrologic system, including aquifer designation, hydraulic characteristics, and quality of the water within the regional aquifers. (2) Create a data base including water use, water levels, lithologic logs, geophysical logs, and chemical analyses of water samples. (3) Describe historic, present, and future problems associated with use of water. (4) Evaluate aquifer system responses to future conditions.

Progress: No progress has been made on this project during the current fiscal year.

Title: GEOHYDROLOGY OF THE ALLUVIAL AND

TERRACE DEPOSITS OF THE NORTH

CANADIAN RIVER FROM OKLAHOMA CITY

TO EUFAULA LAKE, CENTRAL OKLAHOMA

Leader: Havens, John S.

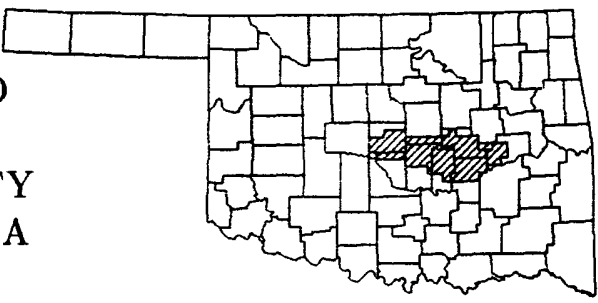

Number: OK065

Problem: Ground water in the alluvial and terrace deposits of the North Canadian River is used extensively for irrigation, municipal, stock, and domestic supplies. Increasing demand has made it necessary for the State to formulate a plan to manage this resource. Quantitative knowledge of the hydrologic system is necessary for proper management. 
Objective: The project is an investigation designed to provide quantitative knowledge of the hydrologic system necessary to manage the aquifer effectively. The specific objectives of the project are: (1) To describe the geologic setting of the alluvial and terrace deposits of the North Canadian River, (2) to provide a quantitative description of the hydrologic system, and (3) to compute the maximum annual yield from the aquifer based on a minimum twenty-year life span.

Progress: The final report has been published. The project is complete.

Cooperating Agency: Oklahoma Water Resources Board

\section{Title: GEOCHEMISTRY OF THE TAR CREEK LEAD-ZINC AREA IN OKLAHOMA \\ Leader: Parkhurst, David L. \\ Number: OK068}

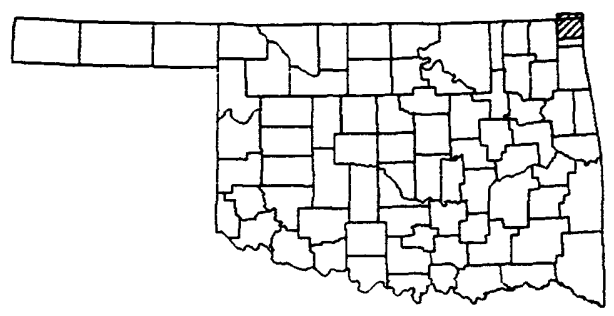

Problem: High concentrations of zinc, lead, and cadmium are found in the water filling abandoned zinc mines of northeastern Oklahoma. The water is draining into Tar Creek and the Grand Lake $O$ ' the Cherokees. The potential exists for downward migration of contaminants from the mines to the Roubidoux aquifer, the important water source for the area.

Objective: (1) To critically evaluate the thermodynamic data necessary to apply geochemical models to the zinc-cadmium-lead system, (2) to determine the geochemical reactions occurring with these metals in the abandoned mines and in the surface water, and (3) to model the chemical reaction of mine water mixing with ground water of the Roubidoux aquifer.

Progress: Data collection and field work on the project are complete. The final report is being written.

Title: AN INVENTORY OF OKLAHOMA SPRINGS

Leader: Funkhouser, Ron A.

Number: OK069

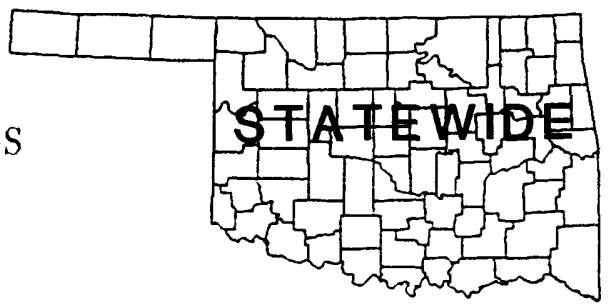

Problem: The flow in many of Oklahoma's streams is augmented in part by springflow. State agencies, and the public, interested in water rights, ground-water contribution to base flow, or streamflow accountability require knowledge of the location, quality, and quantity of flow-particularly in areas where large springflows occur. An annotated state-wide springs report does not exist.

Objective: (1) Review historical data for known springs; (2) do a physical inventory of Oklahoma springs; measure the discharge, $\mathrm{pH}$, temperature, and specific conductance; and (3) collect water samples for laboratory analyses. 
Progress: The project was reactivated in the 1990 fiscal year.

Cooperating Agency: Oklahoma Geological Survey

Title: DIGITAL MODEL ANALYSIS OF THE ROUBIDOUX AQUIFER IN NORTHEASTERN OKLAHOMA

Leader: Christenson, Scott C.

Number: OK070

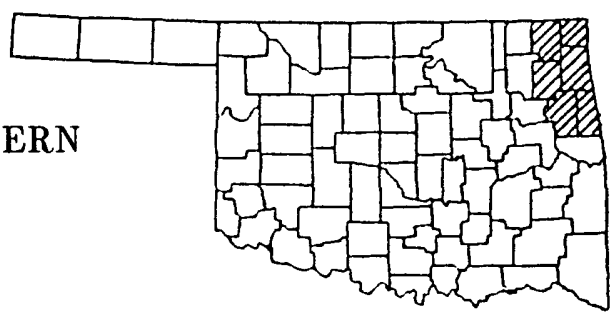

Problem: Water from the Roubidoux aquifer is used for public supplies and industrial purposes. Water users in the area are concerned about declining water levels as a result of withdrawal of water from the aquifer and the possibility of contamination of the water supply from abandoned lead and zinc mines in the northern part of the area. The possibility exists for downward migration of toxic mine water through existing or abandoned leaky well casings or through fractures in rocks that overlie the Roubidoux aquifer.

Objective: The hydraulic properties of the formations above and below the Roubidoux aquifer are unknown. Information about the hydraulic properties of the rocks in the deep formations is needed for a better understanding of the direction and rates of ground-water flow in the Roubidoux aquifer and overlying geologic units.

Progress: The project is completed. A final report combining this project and project OK058 has been approved and released as an Open-File Report 90-570 pending publication by the cooperator.

Cooperating Agency: Oklahoma Geological Survey

Title: GEOHYDROLOGY OF ALLUVIAL AND TERRACE DEPOSITS OF THE CIMARRON RIVER FROM NEAR THE KANSAS STATE LINE TO GUTHRIE, OKLAHOMA

Leader: Adams, Gregory $P$.

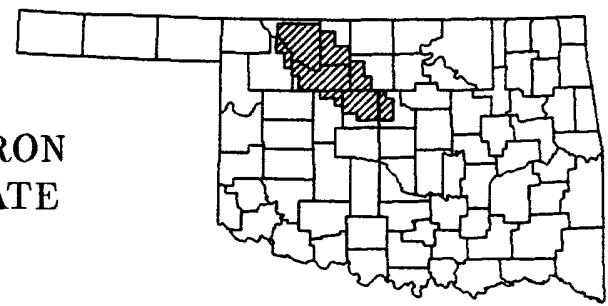

Number: OK072

Problem: Ground water in the alluvial and terrace deposits along the Cimarron River in northwestern Oklahoma is used extensively for irrigation, municipal, stock, and domestic supplies. Increasing demands for water within the State makes it necessary to have a quantitative knowledge of the hydrologic system for formulation of effective management plans. The area of study extends about 115 miles from near Freedom, Okla., to Guthrie, Okla.. This area includes the Cimarron Terrace and associated aquifers.

Objective: (1) To describe the geologic setting of the alluvial and terrace deposits along the Cimarron River from Freedom, Okla. to Guthrie, Okla.; (2) to estimate the approximate 
quantity of water in storage and the approximate annual recharge and discharge from the alluvium and terrace deposits to the Cimarron River; (3) to provide estimates of the effects of future withdrawals from the aquifer by means of a digital model of the aquifer-river system; and (4) to identify sources of existing and potential natural saline pollution.

Progress: A data report, "Hydrologic data for the terrace and alluvial aquifer of the Cimarron River from Freedom to Guthrie, Okla.," has been completed and is in review. Steady-state and transient modeling of the aquifer is in progress. The final report, "Geohydrology of the terrace and alluvial deposits of the Cimarron river from Freedon to Guthrie, Okla.," is being prepared.

Cooperating Agency: Oklahoma Geological Survey

Title: NUMERICAL SIMULATION AND WATERQUALITY ASSESSMENT OF THE RUSH SPRINGS AQUIFER, SOUTHWESTERN OKLAHOMA

Leader: Becker, Mark F.

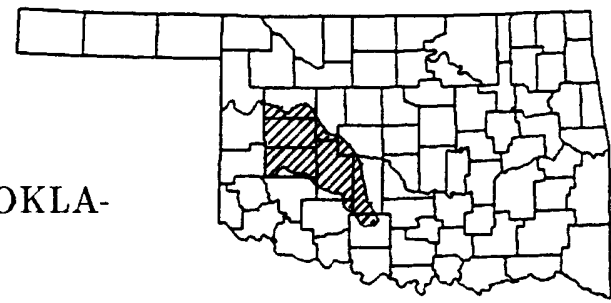

Number: OK073

Problem: Communities, along with agriculture and industry, within and surrounding the study area are dependent upon the Rush Springs aquifer to sustain the current and future economy of the region. Current agricultural and industrial use of irrigation and supply wells could stress the aquifer significantly, reducing the amount of water in storage. Agricultural, industrial, and petroleum exploration activities may have contributed to a decline in water quality.

Objective: The study will obtain water-quality information that will represent current water quality with the study area. By use of the modular ground-water flow model, stresses and changes within aquifer may be simulated, leading to a better understanding of the hydrology of the aquifer.

Progress: In 1989, 34 ground-water samples were collected for water-quality analysis, including 20 pesticide/herbicide samples. During the winter of 1989 , base-flow measurements were made at 36 sites. A network of observation wells has been established and monthly measurements have been made from 1988 through the present. Measurements are made by the Oklahoma Water Resources Board. Starting in the fall of 1989 and ending in the fall of 1990,11 additional wells were drilled. Of the 11 wells, 6 were cored continuously from land surface to the bottom of the well. All 11 wells were completed as observation wells and added to the observation-well network. 
Cooperating Agency: Oklahoma Geological Survey, Oklahoma Water Resources Board

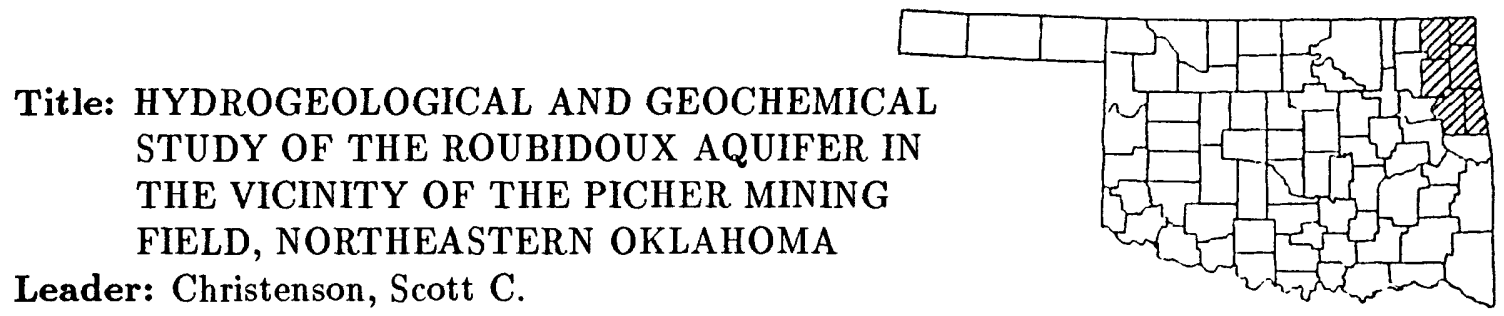
Number: OK074

Problem: Most of the water supply for extreme northeastern Oklahoma is obtained from fractured sandstone and dolomite units in the Roubidoux and associated formations of Cambrian and Ordovician ages. It is anticipated that the demand for water from the principal aquifer, the Roubidoux, will increase in proportion to the population growth of the area. There is concern that the Roubidoux, which averages 150 feet thick and lies between 800 and 1,000 feet below land surface, may be subject to contamination from abandoned mines of the Picher field. Water in the underground lead-zinc mines contains high concentrations of iron, zinc, cadmium, and lead. The contaminated water may migrate from the mines to the Roubidoux via abandoned water wells. A multi-agency effort to locate and plug all such wells began in late 1984. Participation in this effort will provide information in support of other ongoing investigations of the hydrogeology of the Roubidoux aquifer and of the geochemical mechanisms involved in the contamination of surface and ground waters in the vicinity of the Picher mining field.

Objective: To determine the geologic, hydraulic, and chemical characteristics of the Roubidoux Formation and of the overlying formations that separate the Roubidoux from the mined interval. Specific objectives are to: (1) Obtain a suite of geophysical logs for each well prior to plugging; (2) Construct a production well and several observation wells within the abandoned wells; (3) Perform aquifer tests to determine the hydraulic properties and leakage characteristics of the Roubidoux; and (4) Collect chemical and isotope samples to determine the geochemical evolution and age of water in the Roubidoux.

Progress: The project is completed. The final data report is in review.

Cooperating Agency: Oklahoma Water Resources Board

Title: LIMNOLOGY OF SELECTED COAL-MINE PONDS IN THE COAL-MINING REGION OF EASTERN OKLAHOMA

Leader: Parkhurst, Renee $S$.

Number: OK075

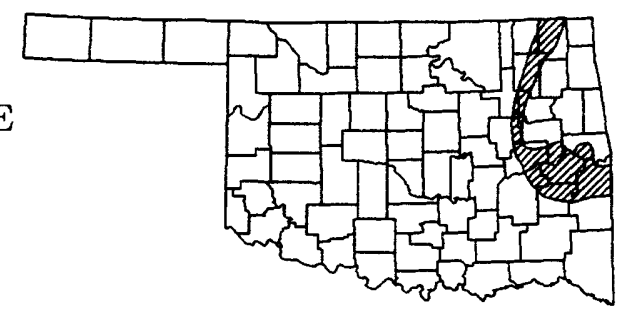

Problem: There is no information on the limnological characteristics of mine ponds and non-mine ponds in the coal-mining region of eastern Oklahoma. Limnological information 
is needed to manage this water resource created by strip mining, and to further understand the limnological processes occurring in mine ponds.

Objective: (1) Describe the limnological characteristics of the strip-mine ponds and other ponds in the area not associated with coal mining, (2) determine if the limnological characteristics of strip-mine ponds are significantly different from those of other ponds, (3) determine if the limnological characteristics of strip-mine ponds are significantly different among (a) those associated with different coal seams, (b) those associated with different mining and reclamation practices and (c) those of different ages and (4) intensively study selected stripmine ponds and non strip-mine ponds to develop an understanding of hydrologic, chemical, and biological processes occurring within the ponds as well as the interrelationships among these processes.

Progress: Data collection and fieldwork on the project are complete. A data report is in review. The final report is being written.

Cooperating Agency: Oklahoma Geological Survey

Title: SIMULATED EFFECTS OF PROJECTED WATER USE ON THE ANTLERS AQUIFER, SOUTHEASTERN OKLAHOMA

Leader: Morton, Robert B.

Number: OK076

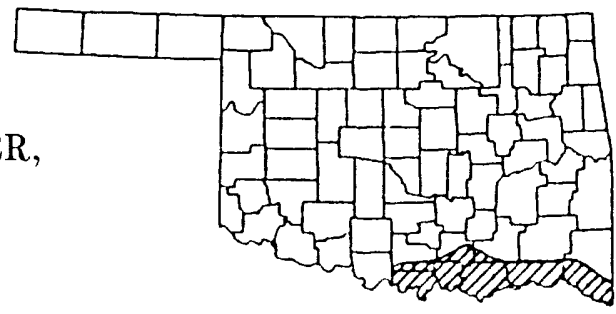

Problem: The Antlers Sandstone of Lower Cretaceous age underlies an area of about 4,400 square miles in southeastern Oklahoma. In terms of volume of water in storage, the Antlers is one of the State's most important sources of fresh water. Current pumpage from the aquifer is relatively minor, but withdrawals are expected to increase as population and industrial growth occur. As ground-water supplies in other parts of the State become fully appropriated or become unsuitable for use, the impetus for interbasin transfer of Antlers water will mount. The U.S. Army Corps of Engineers has made water-use projections for the area spanning several decades. As the next step in the process of areal water-resource planning, the Corps has asked the U.S. Geological Survey to simulate the effects of projected water use on the Antlers aquifer.

Objective: Simulate the effects of projected water use on the Antlers aquifer and present the results for use by water-management agencies. The specific objectives are to: (1) Complete the data base from earlier studies by incorporating new stratigraphic and hydrologic data; (2) adapt previous data matrices, with appropriate changes in boundary conditions and parameters for use with the modular ground-water model; (3) perform model simulations using projected withdrawal rates provided by the Corps; and (4) present the results of the simulations as maps and tables that depict hydrologic information for each decennial year from 1990 to 2040 .

Progress: The final report has been approved and is awaiting final drafting and publication. 
Cooperating Agency: U.S. Army Corps of Engineers

Title: STREAMFLOW STATISTICS

FOR OKLAHOMA STREAMS

Leader: Tortorelli, Robert L.

Number: OK079

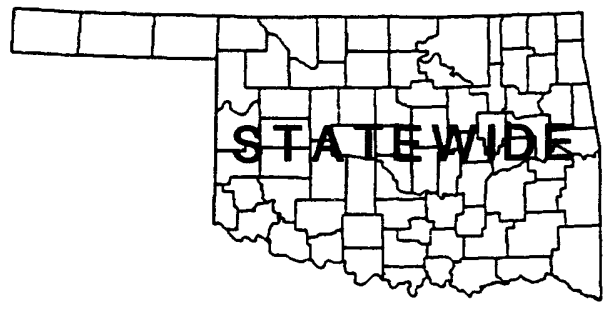

Problem: Most statistical data on streams in Oklahoma have not been published using the common period of record. For some statistics, there has been 10 years of additional data collected since last publication. There is a need to use more current information in statistics needed in design problems.

Objective: Compute streamflow statistics using most current data and publish in one publication.

Progress: Project is completed and final report published.

Cooperating Agency: Oklahoma Water Resources Board

Title: HYDROGEOLOGIC CHARACTERISTICS

OF SHALEY FORMATIONS IN OKLAHOMA, AND THEIR SUITABILITY FOR

HAZARDOUS WASTE CONTAINMENT

Leader: Hanson, Ronald L.

Number: OK080

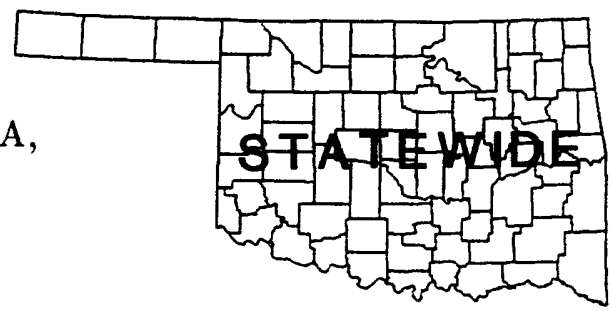

Problem: American industry produces millions of tons of potentially hazardous waste each year. In Oklahoma, industrial wastes are disposed of by near-surface burial and subsurface injection. Only one burial site currently is licensed in Oklahoma, but pressure is mounting for the selection and approval of other sites. A reconnaissance of geologic formations in Oklahoma suitable for the disposal of hazardous wastes indicates that thick shales would be most favorable for near-surface burial of wastes. Few data are available, however, on the hydraulic properties and ground-water flow systems of shales.

Objective: (1) Conduct a literature search on the hydrology of shales; (2) determine which physical properties of shale may be used as an index of permeability and fracture tendency; (3) select four representative shales for study, map the outcrop areas, drill test holes, and describe the detailed geology at the test sites; (4) evaluate the hydraulic and selected physical properties of the shales; (5) Evaluate the fracture tendency of shales and the resulting effect on ground-water flow; and (6) suggest hydrogeologic and physical criteria or guidelines for use in evaluating the suitability of shales for waste disposal. 
Progress: All field data collection has been completed and selected core samples have been evaluated. Resignation of the project chief early in 1990 necessitated putting the project temporarily on hold. Preparation of a report describing the results of the field testing is scheduled to start again during 1991.

Cooperating Agency: Oklahoma Geological Survey

Title: HYDROGEOLOGY OF THE BLAINE AQUIFER AND ASSOCIATED UNITS IN SOUTHWESTERN OKLAHOMA

Leader: Runkle, Donna L.

Number: OK081

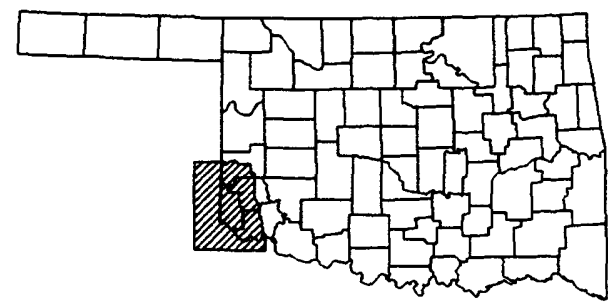

Problem: The Blaine aquifer consists of cavernous gypsum and dolomite beds interlayered with shales in the Permian Blaine Formation in Harmon, Jackson, and Greer Counties in southwestern Oklahoma. Ground water from the Blaine supports a local agriculture based mainly on irrigated cotton, corn, and wheat. Declining water levels in parts of the Blaine aquifer are evidence that water is being withdrawn at rates greater than it is being replenished. Although the aquifer has been artificially recharged since about 1961, much of the effort was abandoned after 1975. Water in the Blaine aquifer is not used for human consumption because of the large dissolved-solids concentrations. The calcium sulfate-type water in the Blaine is acceptable for irrigation of salt-tolerant crops.

Objective: (1) Evaluate and map the stratigraphy and structure of all geologic units in the study area adjacent to the Blaine Formation; (2) evaluate the hydrology of the Blaine and adjacent units; (3) determine the distribution of major and selected trace and organic (agriculturally applied) chemical constituents in the aquifers; (4) analyze the effects that extensive irrigation and artificial recharge have had on the aquifers to determine what effect they have had on the quantity and quality of water in the aquifer; and (5) determine if opportunities exist for additional artificial recharge.

Progress: A data report has been completed and is in review. An analytical report is in preparation and will be completed following development and application of a ground-water digital flow model of the aquifer scheduled for 1991.

Cooperating Agency: Oklahoma Water Resources Board, Oklahoma Geological Survey 
Title: HYDROGEOLOGY AND WATER QUALITY

OF THE GARBER-WELLINGTON AND

ASSOCIATED AQUIFERS, CENTRAL

OKLAHOMA

Leader: Christenson, Scott C.

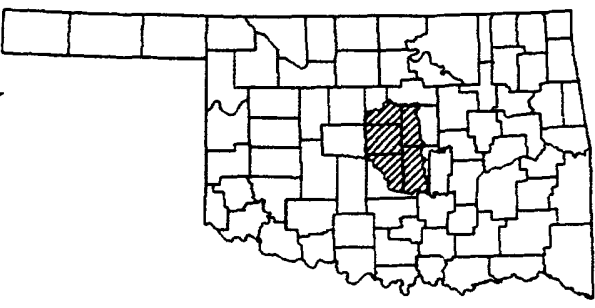

Number: OK082

Problem: The Central Oklahoma aquifer, which includes in descending order the Garber Sandstone and Wellington Formation, the Chase Group, the Council Grove Group, the Admire Group, and overlying alluvium and terrace deposits, underlies about 3,000 square miles of central Oklahoma and is used extensively for municipal, industrial, commercial, and domestic water supplies. The aquifer was selected for study by the National Water Quality Assessment (NAWQA) program because it is a major source for water supplies in central Oklahoma and because it has several known or suspected water-quality problems. Known problems include concentrations of sulfate, chloride, selenium, chromium, and gross-alpha activity that exceed drinking-water standards. Suspected problems include possible contamination of the aquifer by oil-field brines and drilling fluids, pesticides, industrial chemicals, septic-tank effuent, fertilizers, and leakage from sewage systems and underground tanks used for storage of hydrocarbons.

Objective: There are four major objectives of the Central Oklahoma aquifer project. The first objective is the collection and analysis of existing information, including chemical, hydrologic, and land-use data. The second objective is the geohydrologic and geochemical investigations of the aquifer flow system. The third objective is the sampling for a wide variety of inorganic, organic, and radioactive constituents as part of a regional survey that will produce a consistent set of data among all ground-water pilot projects. These data can be used to: (1) Define regional ground-water quality within the Central Oklahoma aquifer, and (2) compare water quality in the Central Oklahoma aquifer to the water quality in the other ground-water study units of the NAWQA program. The fourth objective is topical studies that will address, in more detail, some of the major water-quality issues pertaining to the aquifer.

Progress: Work is continuing on the project. A total of six reports have been published, including "Hydrogelogic maps of the Central Oklahoma aquifer, Oklahoma," by S.C. Christenson, R.B. Morton, and B.A. Mesander. Numerous other reports are in progress and have been planned. Water-quality sampling is complete. 
Title: PRELIMINARY INVESTIGATION OF THE HYDROGEOLOGY OF THE CHICKASAW NATIONAL RECREATION AREA

Leader: Hanson, Ronald L.

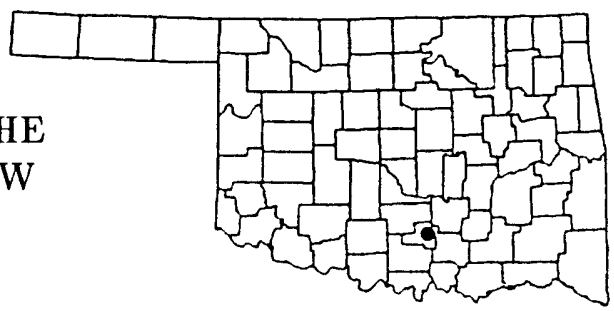

Number: OK084

Problem: The Chickasaw National Recreational Area (CNRA) is located in south-central Oklahoma in Murray County near Sulphur, Okla.. Initially, the CNRA (originally established as Platt National Park in 1902) contained about 33 flowing freshwater and mineralized springs. Numerous flowing wells were drilled in the general vicinity of the CNRA during the 1920's and 1930's. Over the years, the mineral springs have dried up and discharge from some of the freshwater springs and flowing wells has significantly declined. At present, only about five springs flow intermittently.

Objective: To review the hydrologic and geologic data presently available in the general region of the CNRA and evaluate all hydrologic data collected to date. A detailed study plan will be prepared outlining the study approach necessary to obtain a full understanding of the hydrologic system and the analysis required to explain the depletion of flow from the springs and flowing wells.

Progress: All published reports related to the study area have been reviewed. The existing climatic, geologic, and hydrologic data, including precipitation, wells logs, streamflow data, ground-water levels, flowing well discharges, ground-water pumpage, and water-quality data have been entered into computer data files. A report describing the relation of this information to historic spring and well discharge has been prepared and is in review. Four project proposals-each outlining different levels of work to obtain a better understanding of the hydrologic system-have been prepared.

Cooperating Agency: National Park Service

\section{Title: FACILITATING THE ANALYSIS OF GROUND- WATER SYSTEMS USING A GEOGRAPHIC INFORMATION SYSTEM}

Leader: Scott, Jonathon C.

Number: OK085

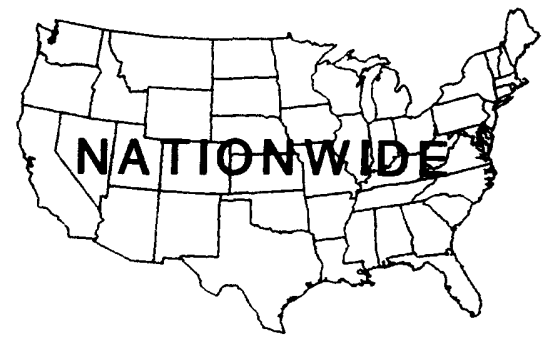

Problem: Ground-water hydrologists need sophisticated computer software to aid them in the analysis of ground-water systems. Geographic Information Systems (GIS) provide powerful map making and analysis capability, however, system integration programming is needed to transform this software into a productive tool. 
Objective: (1) Develop software to transport water-quality and ground-water site inventory data into the Geographic Information System (GIS), (2) develop software to randomly choose a set of areally distributed sampling locations from a stratified set of polygons describing the study area, (3) develop software to assist with visualizing the results of finitedifference numerical simulations performed with the Modular Ground-water Flow Model, and (4) develop software to aid in the establishment of relationships between land use and ground-water quality using statistical methods.

Progress: The software has been written and tested. Four reports have been published in the Water-Resources Investigations Reports series. Project is completed.

Title: ALTUS AFB IRP STUDY: RI/FS STAGE 1

Leader: Stoner, Jerry D.

Number: OK086

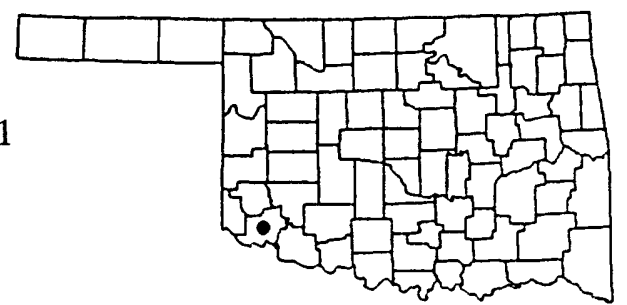

Problem: Altus Air Force Base (AFB) was established as a flight training facility in 1942. An investigation of historical waste-disposal practices on the 2,525-acre Base identified nine former disposal sites that may pose a continued hazard to humans and the environment. The sites include fire protection training areas, landfills, and washracks. A gas station presumed to have a leaking tank is the tenth site that will be investigated as part of the Altus Installation Restoration Program (IRP) Study. No major aquifers underlie the area.

Objective: For each of the ten sites the study objectives are: (1) Determine the public health and environmental requirements to develop data quality objectives and evaluate the threat of the contaminants to the public health and welfare; $(2)$ collect sufficient hydrologic and chemical data to support the needs of this phase of the IRP study; (3) using these data, determine the potential risk to human health and welfare or to the environment from the contaminants identified at each site; and (4) develop preliminary alternative remedial actions for each site except for those sites for which no significant effect is found and a No Further Action Decision Document can be prepared.

Progress: All field work has been completed. A total of 44 monitoring wells and 26 boreholes were installed on Altus Air Force Base. Soil samples were collected from the boreholes and from selected monitoring wells during the installation phase. One round of water samples was collected from the monitoring wells and the surface drainages on Altus Air Force Base. The Informal Technical Information Report containing the basic analytical data was prepared and delivered to the U.S. Air Force. The technical report for this RI/FS Stage 1 study was completed and is under review by the U.S. Air Force.

Cooperating Agency: U.S. Air Force 
Title: CURRICULUM DEVELOPMENT IN THE COMPUTER SCIENCES AT LANGSTON UNIVERSITY

Leader: Scott, Jonathon C.

Number: OK089

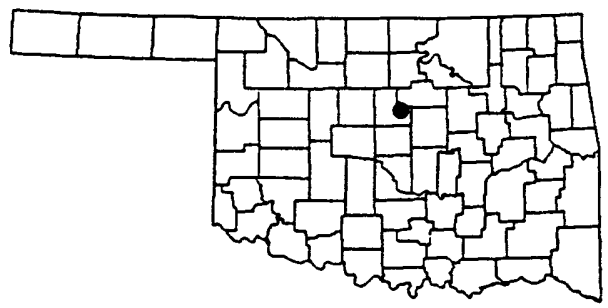

Problem: Langston University, a Historically Black University located in central Oklahoma, is trying to develop a curriculum in the computer sciences. The University already has a good curriculum for business applications of computer technology, and is expanding its curriculum in the use of computing technology in scientific investigations.

Objectives: To help expand the computer science curriculum at Langston University. Secondary objectives are to improve employment opportunities in the sciences for Blacks, and to provide the U.S. Geological Survey with well trained, employable computer scientists.

Progress: Preliminary plans were made for a visiting-guest-lecture series. One guest lecture by Jonathon Scott was presented on the history of computing technology. A workstation was installed in the Earth Sciences Computer Laboratory. The workstation is connected to 11 terminals, a laser printer, an optical disk drive, 2 magnetic disk drives, and a localarea network. An Open-File Report describing cooperative activities of the U.S. Geological Survey with Historically Black Colleges and Universities has been published.

Title: WATER-LEVEL MONITORING IN THE HIGH PLAINS AQUIFER

Leader: May, Jayne E.

Number: OK090

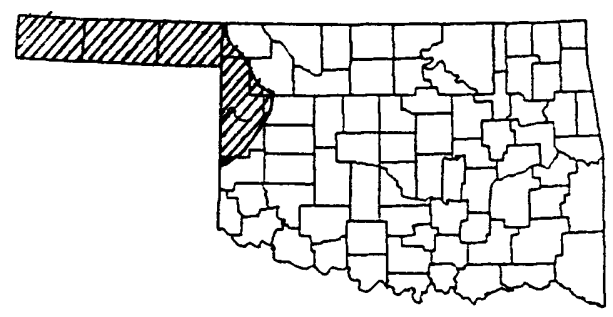

Problem: Most of the land surface overlying the High Plains aquifer is intensively developed for agriculture. Because the High Plains region is semiarid and subject to frequent droughts, the water demands are met largely with irrigation water drawn from the High Plains aquifer. Extensive long-term pumpage from the aquifer has resulted in large waterlevel declines and depletion of storage in many areas.

Objective: To evaluate the current water-level monitoring network and to make additions and deletions of annually measured observation wells and recorder wells as needed to improve its cost and informational effectiveness.

Progress: The location of all existing wells has been reviewed; these sites have been plotted on 1:100,000 planimetric maps. Two reports, "Water-level changes in the High 
Plains aquifer underlying parts of South Dakota, Wyoming, Nebraska, Colorado, Kansas, New Mexico, Oklahoma, and Texas-Predevelopment through nonirrigation season 198788 ," and for the following year, 1988-90, have been published as U.S. Geological Survey Water-Resources Investigations Report 89-4073 and 90-4153.

Cooperating Agency: Oklahoma Water Resources Board

Title: SOURCE AND MOVEMENT OF NATURALLY OCCURRING TOXIC SUBSTANCES IN THE CENTRAL OKLAHOMA AQUIFER

Leader: Schlottmann, Jamie L. Number: OK091

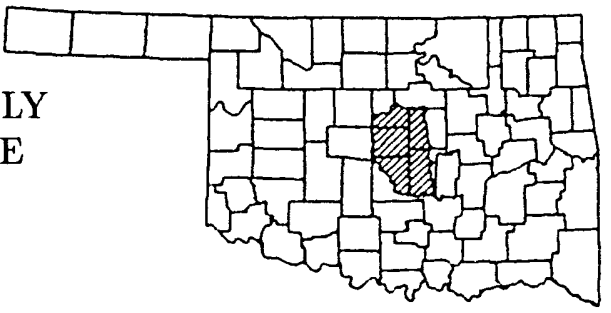

Problem: Ground water in some wells in the Central Oklahoma aquifer contains arsenic, chromium, residual alpha-particle activities, and selenium in amounts that exceed the U.S. Environmental Protection Agency's primary drinking-water standards. Uranium concentrations are commonly greater that $10 \mathrm{pCi} / \mathrm{L}$.

Objective: Determine (1) The distribution of the substances in ground water of the aquifer; (2) the solid phase sources of the substances; and (3) the processes mobilizing the substances into the ground water.

Progress: Two deep test holes were drilled and sampled. Three data reports were written containing the results of (1) Rock chemical analyses, (2) mineralogic and petrographic analyses, and (3) chemical analyses of water and geophysical logs. The first report is published and the other two are in review. A report describing the results of the project is in progress. Two abstracts on the project were published.

Cooperating Agency: Association of Central Oklahoma Governments

Title: EVALUATION OF THE IMPACT OF OIL REFINERY PRODUCTS AND WASTES ON THE GROUND- AND SURFACE-WATER RESOURCES NEAR CYRIL IN SOUTHEASTERN CADDO COUNTY, OKLAHOMA

Leader: Stoner, Jerry D.

Number: OK092

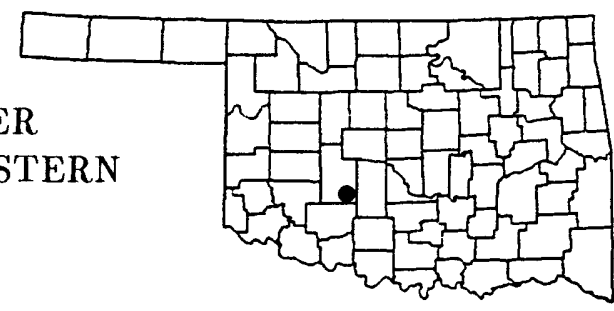

Problem: Water from the Rush Springs Sandstone, a major aquifer in southwestern Oklahoma, is used for irrigation, public, domestic, and livestock supplies. Since the early 1920's, crude oil has refined in this area near Cyril, Okla. in Caddo County. Even though refinery operations have now been suspended, the past operations are potential sources of contamination of the water in the Rush Springs aquifer and in the local surface-water drainages. 
Four potential sources of contamination of the water resources of the area, resulting from past refinery operations at Cyril have been identified and are: (1) Spillage and leakage of crude petroleum and finished products, (2) acid sludges buried on site, (3) buried lime and caustic waste sites, (4) the API Separator and soil farm.

Objective: To evaluate the effects of oil-refinery products and wastes on the ground- and surface-water quality in southeastern Caddo County near Cyril, Okla.

Progress: A surface-water gaging station has been located on Gladys Creek downstream from the old refinery. Water-quality samples have been collected at this site and at a site on Gladys Creek upstream from the refinery. A review of the literature was made and the available data from any past investigations in the area have been obtained. A Superfund $\mathrm{RI} / \mathrm{FS}$ investigation by another agency is in progress at the refinery and the data resulting from that investigation are being obtained as they become available. A ground-water well inventory was made and water levels were measured in selected wells. Preparation of a water-level map using all available data is under way.

Cooperating Agency: Oklahoma Geological Survey

Title: AUTOMATED QUALITY ASSURANCE (AQUA)

Leader: Scott, Jonathon C.

Number: OK093

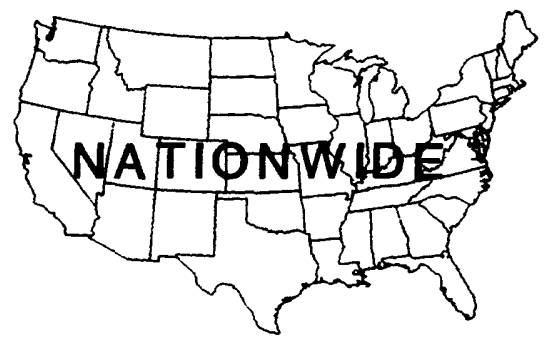

Problem: Errors have been incorporated into computerized data bases from a number of sources. Some errors are simple typographic mistakes that occurred when data were transcribed from paper into digital form. Other errors occurred because the personnel preparing the data for entry into the computer lacked proper training (map-reading skills or hydrologic expertise). Because the Survey's hydrologic data have been migrated through several data-management systems some subtle, systematic errors have been introduced into the computerized data bases. For example, ground-water data have been moved from the ABC system, to System 2000 Ground-Water Site Inventory (GWSI), to the National Water Information System (NWIS) GWSI. Errors have resulted from unforeseen or undetected modifications that were made to data during the conversion process from one data management system to another. When Survey hydrologists begin new projects, one of the initial phases is to compile and analyze existing data for the study area. Normally, a significant amount of time and expertise is needed to correct errors in the data. When new projects require the use of data from other organizations, the time needed for quality-control is increased. Data quality control commonly is the largest single task, in terms of manpower expense, that must be performed for ground-water projects.

Objective: The Survey needs to develop automated methods for detecting errors in hydrologic data. The purpose of the project is to develop computer software to assist hydrologists with the problem of detecting these errors. By developing the computer software, the Survey will have a system which can be employed by any of its offices for the detection of errors in hydrologic data. 
Progress: Development of the software is partially complete.

Title: BLAINE GYPSUM AQUIFER AND WOODWARD GROUND-WATER RECHARGE DEMONSTRATION PROJECTS

Leader: Hanson, Ronald L. Number: OK094

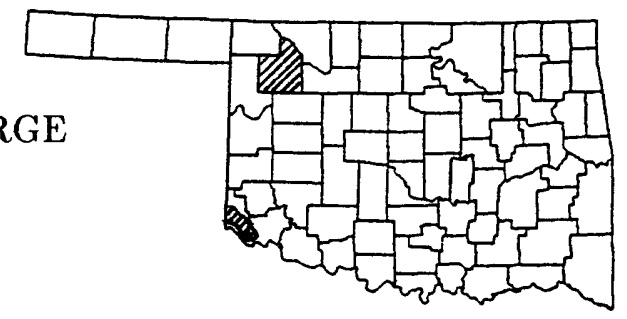

Problem: The Blaine Gypsum aquifer and Woodward ground-water recharge projects are two of several U.S. Bureau of Reclamation projects selected for study under the High Plains States Groundwater Demonstration Program Act of 1983. The purpose of these studies is to advance the state of the art of artificial ground-water recharge.

Objective: The Blaine Gypsum project objectives are to evaluate the recharge potential of the Blaine aquifer. The project area presently diverts surface runoff from precipitation and irrigation tailwater to recharge wells completed in fracture or solution zones of the aquifer. The surface water will be impounded by two diversion structures and additional recharge and monitoring wells will be established within the impoundment area. The Woodward Ground-Water Project objectives are to evaluate ground-water flow characteristics resulting from placement of a subsurface dam in the ground-water flow path between a Woodward municipal water-supply well and the North Canadian River and to determine the potential effects that this dam may have on the river and spring discharge at nearby Boiling Springs State Park. The Woodward study will be conducted in two phases, a feasibility study and (assuming feasibility) an actual implementation of the project by installing a grout dam in the terrace deposits down gradient from the well. The U.S. Geological Survey will provide technical support and review of these projects as they relate to planning, surfaceand ground-water monitoring, and report preparation.

Progress: The sponsoring agency for these studies is the Oklahoma Water Resources Board. They have completed development, monitoring, and mitigation plans for the Blaine project, and these plans have been reviewed and approved by the U.S. Environmental Protection Agency, U.S. Fish and Wildlife Service, and U.S. Geological Survey. The Woodward feasibility study is being conducted by the Oklahoma Water Resources Board, utilizing a three-dimensional finite-difference ground-water flow model to simulate ground-water conditions at the study site with selected subsurface dam configurations placed in the flow path.

Cooperating Agencies: Oklahoma Water Resources Board, U.S. Bureau of Reclamation, U.S. Environmental Protection Agency, U.S. Fish and Wildlife Service, and U.S. Geological Survey 
Title: GROUND WATER, WELLSTON, OKLAHOMA

Leader: Schlottmann, Jamie L.

Number: OK095

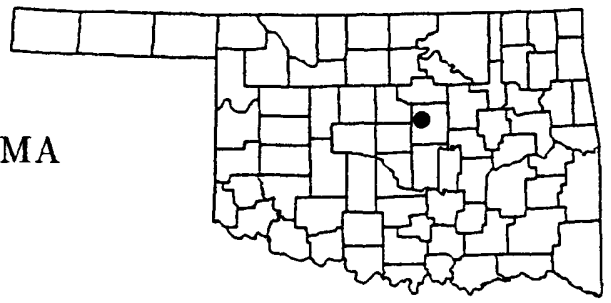

Problem: Ground water in some wells in the Wellston area contain residual alpha-particle activities that exceed the U.S. Environmental Protection Agency's primary drinking-water standards. Uranium concentrations are commonly greater than $10 \mathrm{pCi} / \mathrm{L}$.

Objective: (1) Test theories developed as part of the Naturally Occurring Toxic Substances (NOTS) project pertaining to water chemistry associated with the substances, (2) determine vertical distribution of radioactive substances in the ground water, and (3) determine whether a test hole drilled in the area could intercept sand layers that would produce adequate quantities of water for a production well containing acceptable drinking water.

Progress: The well inventory was completed and test hole was drilled. Water samples were collected and aquifer tests were completed. Sandstone layers were found that would supply adequate quantities of water for a production well, but the water produced from the sands contained large amounts of radioactivity. The water chemistry associated with the radioactivity agreed with that found by the NOTS project. An oral report of the results of the study was presented to the Town of Wellston. Project was completed.

Cooperating Agency: Association of Central Oklahoma Governments

Title: HYDROLOGY OF BYRDS MILL SPRING

Leader: Savoca, Mark E.

Number: OK096

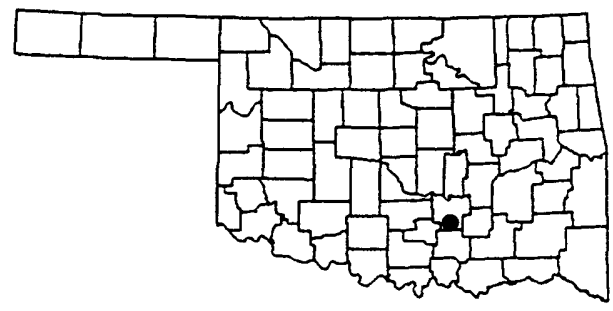

Problem: A 1987 Oklahoma Supreme Court ruling threatens to change a management policy that allowed Oklahoma communities to legally transfer appropriated water from one stream basin to another. The City of Ada may lose its right to withdraw water from Byrds Mill Spring and three nearby city wells, particularly if it can be shown that withdrawals from the Arbuckle aquifer significantly affect local ground-water levels or spring flows.

Objective: (1) Establish a monitoring program to measure the water diverted from Byrds Mill Spring to the City of Ada; (2) measure the amount of water pumped by the city from the three city wells; and (3) evaluate the effect of these withdrawals on local ground-water levels and spring flow.

Progress: Monitoring equipment has been installed on Byrds Mill Spring to measure the spring flow and water diverted to Ada; a monitoring system has been installed to measure the amount of water pumped from the city wells. A report containing available data is in preparation. 
Cooperating Agency: Oklahoma Water Resources Board

Title: SAC AND FOX GROUND-WATER STUDY

Leader: Abbott, Marvin $M$.

Number: OK097

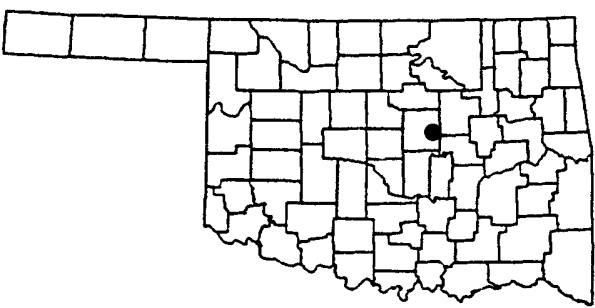

Problem: Tribal Reserve Lands of the Sac and Fox Nation of Oklahoma are located in Lincoln County, Okla.. Oil production began in this area in the 1930's and water injection for secondary recovery and salt-water disposal began in the 1950's. Studies indicate that extensive degradation of surface and ground water in the area may exist as a result of these oil-production activities.

Objective: (1) Determine the water-table surface and gradient, and ground-water quality and quantity in the 960 -acre Tribal Reserve; (2) locate a source of water capable of supplying present and future needs of the Tribe; and (3) assess the potential for contamination of the water supply.

Progress: A field survey of regional ground-water levels and ground-water quality has been completed and surface resistivity measurements have been obtained describing the thickness of fresh water underlying the Tribal lands. Full funding for this study did not materialize and work required to meet all objectives was not accomplished. A letter describing the results of the investigation to date has been submitted to the Bureau of Indian Affairs.

Cooperating Agencies: Bureau of Indian Affairs 


\section{OTHER DISTRICT ACTIVITIES IN SUPPORT OF THE STATE'S WATER PROGRAMS}

As part of the Geological Survey's responsibility to provide hydrologic information to all water users, the Survey participates in numerous other activities in addition to the regular Federal and State cooperative programs of hydrologic data collection and analysis. These other activities include involvement in various water-related committees and task forces, the review of technical reports on hydrology prepared by other agencies and universities, answering requests for hydrologic data and related information, and presenting information to schools, civic groups, and other interested groups on the water resources of Oklahoma and the Nation. Some of the current special activities are:

Committee Activities - Members of the Oklahoma District staff participate in various technical committees and task forces dealing with water problems. Included are: (1) The Governor's Coordinating Committee on Water Resources Research; (2) a ground-water committee to develop water-quality standards for Oklahoma's major aquifers; (3) a water-quality advisory board that reviews the State's ambient surface-water quality monitoring network, and selects stream- and lake-sampling frequency; (4) four interstate river compact commissions; (5) a Rural Abandoned Mine Programs (RAMP) committee, which selects for reclamation abandoned surface mines based on their hazard to life and health; and (6) an American Society of Civil Engineers' task committee on water requirements of native vegetation.

Special Activities-Beginning in 1984, the Geological Survey published the first of an annual series of Water-Supply Papers, "National Water Summary", describing the conditions, trends, availability, quality, and use of the Nations's water resources. Each of these reports contains chapter devoted to Oklahoma. In addition to yearly hydrologic events, the reports address: Water issues (1983), selected water-quality trends and ground-water resources (1984), surface-water resources (1985), ground-water quality (1986), water supply and demand (1987), hydrologic events and floods and droughts (1988-89, unpublished), stream water quality (1990-91, unpublished).

The Oklahoma Data Section completed the renovation of 17 gaging stations in Oklahoma and one in Texas. The work was requested by the Corps of Engineers and consisted of replacing gaging stations and installing multiple orifice systems to insure continuous gage operation above the Maximum Probable Flood.

The Corps also asked the District to assume the operation and maintenance responsibilities of 15 Corps-operated lake, reservoir, river, stage, DCP, and precipitation sites due to a reorganization after a reduction in personnel. 


\section{BIBLIOGRAPHY OF OKLAHOMA HYDROLOGY- REPORTS PREPARED BY THE U.S. GEOLOGICAL SURVEY AND PRINCIPAL COOPERATING AGENCIES, 1901-90}

Compiled by John S. Havens

[Revision of U.S. Geological Survey Open-File Report 89-33, with the addition of reports printed since publication of that report. Reports published or added from 1988 through September 1990 are marked with a pointing hand in the left margin.]

\section{U.S. GEOLOGICAL SURVEY Professional Papers}

Bedinger, M.S., and Sneigocki, R.T., 1976, Summary appraisals of the Nation's groundwater resources-Arkansas-White-Red Region: U.S. Geological Survey Professional Paper 813-H, 31 p.

Bergman, D.L., and Sullivan, C.W., 1963, Channel changes on Sandstone Creek near Cheyenne, Oklahoma, in Geological Survey Research 1963: U.S. Geological Survey Professional Paper 475-C, p. C145-C148.

Clark, W.E., 1963, Evapotranspiration and relation of ground water to surface water in the Pond Creek basin, Oklahoma, in Geological Survey Research 1962: U.S. Geological Survey Professional Paper 450-E, p. E142-E145.

Leonard, A.R., and Ward, P.E., 1962, Use of $\mathrm{Na} / \mathrm{Cl}$ ratios to distinguish oil field from salt springs brines in western Oklahoma, in Geological Survey Research 1962: U.S. Geological Survey Professional Paper 450-B, p. B126-B127.

U.S. Geological Survey, 1954, Water-loss investigations; Lake Hefner studies, technical report: U.S. Geological Survey Professional Paper 269, 158 p.

Ward, P.E., 1962, Shallow halite deposits in the Flowerpot Shale in southwestern Oklahoma: U.S. Geological Survey Professional Paper 450-E, p. E40-E42.

Ward, P.E., and Leonard, A.R., 1961, Hypothetical circulation of ground water around salt springs in western Oklahoma, Texas, and Kansas, in Geological Survey Research 1961: U.S. Geological Survey, Professional Paper 424-D, p. D150-D151. 


\section{Water-Supply Papers}

Bedinger, M.S., Reed, J.E., Wells, C.V., and Swafford, B.F., 1970, Methods and applications of electrical simulation in ground-water studies in the lower Arkansas and Verdigris River valleys, Arkansas and Oklahoma: U.S. Geological Survey Water-Supply Paper 1971, $71 \mathrm{p}$.

Blumer, S.P., 1986, Oklahoma, Surface-water resources, in U.S. Geological Survey, 1986, National Water Summary, 1985: U.S. Geological Survey Water-Supply Paper 2300, p. $375-382$.

Dover, T.B., Leonard, A.R., and Laine, L.L., 1968, Water for Oklahoma: U.S. Geological Survey Water-Supply Paper 1890, 107 p.

Gould, C.N., 1905, Geology and water resources of Oklahoma: U.S. Geological Survey Water-Supply Paper 148, 178 p.

Havens, J.S., Marcher, M.V., and Schuelein, J.W., 1985, Oklahoma-Ground-water resources, in U.S. Geological Survey, 1985, National Water Summary 1984: U.S. Geological Survey Water-Supply Paper 2275, 467 p.

Heimann, D.C., Stoner, J.D., McTernan, E.W., and Schuelein, J.W., 1990, OklahomaWater supply and use, in U.S. Geological Survey, 1990, National Water Summary 1987: U.S. Geological Survey Water-Supply Paper 2350, 553 p.

Horak, W.F., and Stoner, J.D., 1988, Oklahoma-Ground-water quality, in U.S. Geological Survey, 1988, National Water Summary 1986: U.S. Geological Survey Water-Supply Paper 2325, 560 p.

Kennon, F.W., 1966, Hydrologic effects of small reservoirs in Sandstone Creek watershed, Beckham and Roger Mills Counties, western Oklahoma: U.S. Geological Survey WaterSupply Paper 1839-C, 39 p.

Leonard, A.R., 1963, Oklahoma, in The role of ground water in the Nation's water situation: U.S. Geological Survey Water-Supply Paper 1800, p. 671-698.

Marine, I.W., 1963, Correlation of water-level fluctuations with climatic cycles in the Oklahoma Panhandle: U.S. Geological Survey Water-Supply Paper 1669-K, 10 p.

Renick, B.C., 1925, Additional water supplies for the city of Enid, Oklahoma: U.S. Geological Survey Water-Supply Paper 520-B, p. 15-26.

Schwenneson, A.T., 1915a, Ground water for irrigation in the vicinity of Enid, Oklahoma: U.S. Geological Survey Water-Supply Paper 345-B, p. 11-23. 
— 1915b, Ground water for irrigation in the valley of North Fork of Canadian River near Oklahoma City, Oklahoma: U.S. Geological Survey Water-Supply Paper 345-D, p. 41-51.

Stoner, J.D., 1985, Dissolved solids in the Arkansas River Basin, in U.S. Geological Survey, 1985, National Water Summary 1984: U.S. Geological Survey Water-Supply Paper 2275,467 p.

Tanaka, H.H., 1972, Geohydrology of the lower Verdigris River valley between Muskogee, and Catoosa, Oklahoma: U.S. Geological Survey Water-Supply Paper 1999-A, 23 p.

Tanaka, H.H., Hollowell, J.R., and Murphy, J.J., 1966, Hydrology of the alluvium of the Arkansas River, Muskogee, Oklahoma, to Fort Smith, Arkansas, with a section on Chemical quality of the water, by J.J. Murphy: U.S. Geological Survey Water-Supply Paper 1809-T, $42 \mathrm{p}$.

Thompson, D.C., 1922, Ground water for irrigation near Gage, Ellis County, Oklahoma: U.S. Geological Survey Water-Supply Paper 500-B, p. 33-53.

U.S. Geological Survey, 1954, Floods of May 1951 in western Oklahoma and northwestern Texas: U.S. Geological Survey Water-Supply Paper 1227-B, p. 135-199.

1984, Oklahoma water issues, in U.S. Geological Survey, 1984, National Water Summary 1983-Hydrologic events and issues, U.S. Geological Survey Water-Supply Paper $2250,243 \mathrm{p}$.

Water-Supply Papers containing ground-water level data for Oklahoma

\begin{tabular}{cccc}
\hline $\begin{array}{c}\text { Calendar } \\
\text { Year }\end{array}$ & $\begin{array}{c}\text { Water-Supply } \\
\text { Paper }\end{array}$ & $\begin{array}{c}\text { Calendar } \\
\text { Year }\end{array}$ & $\begin{array}{c}\text { Water-Supply } \\
\text { Paper }\end{array}$ \\
\hline 1935 & 777 & 1948 & 1129 \\
1936 & 817 & 1949 & 1159 \\
1937 & 840 & 1950 & 1168 \\
1938 & 845 & 1951 & 1194 \\
1939 & 886 & 1952 & 1244 \\
1940 & 909 & 1953 & 1268 \\
1941 & 939 & 1954 & 1324 \\
1942 & 947 & 1955 & 1407 \\
1943 & 989 & $1956-59$ & 1549 \\
1944 & 1019 & $1960-64$ & 1824 \\
1945 & 1026 & $1965-69$ & 1979 \\
1946 & 1074 & $1970-74$ & 2172 \\
1947 & 1099 & & \\
\hline
\end{tabular}


Water-Supply Papers containing surface-water data for Oklahoma

\begin{tabular}{|c|c|c|c|}
\hline $\begin{array}{l}\text { Water } \\
\text { Year }\end{array}$ & $\begin{array}{c}\text { Water-Supply } \\
\text { Paper }\end{array}$ & $\begin{array}{l}\text { Water } \\
\text { Year }\end{array}$ & $\begin{array}{c}\text { Water-Supply } \\
\text { Paper }\end{array}$ \\
\hline 1899 & 37 & 1932 & 732 \\
\hline 1900 & 50 & 1933 & 747 \\
\hline 1901 & $65,66,75$ & 1934 & 762 \\
\hline 1902 & 83,84 & 1935 & 787 \\
\hline 1903 & 98,99 & 1936 & 807 \\
\hline 1904 & 128,131 & 1937 & 827 \\
\hline 1905 & 169,173 & 1938 & 857 \\
\hline 1906 & 205,209 & 1939 & 877 \\
\hline $1907-08$ & 247 & 1940 & 897 \\
\hline 1909 & 267 & 1941 & 927 \\
\hline 1910 & 287 & 1942 & 957 \\
\hline 1911 & 307 & 1943 & 977 \\
\hline 1912 & 327 & 1944 & 1077 \\
\hline 1913 & 357 & 1945 & 1037 \\
\hline 1914 & 387 & 1946 & 1057 \\
\hline 1915 & 407 & 1947 & 1087 \\
\hline 1916 & 437 & 1948 & 1117 \\
\hline 1917 & 457 & 1949 & 1147 \\
\hline 1918 & 477 & 1950 & 1177 \\
\hline $1919-20$ & 507 & 1951 & 1211 \\
\hline 1921 & 527 & 1952 & 1241 \\
\hline 1922 & 547 & 1953 & 1281 \\
\hline 1923 & 567 & 1954 & 1341 \\
\hline 1924 & 587 & 1955 & 1391 \\
\hline 1925 & 607 & 1956 & 1441 \\
\hline 1926 & 627 & 1957 & 1511 \\
\hline 1927 & 647 & 1958 & 1561 \\
\hline 1928 & 667 & 1959 & 1631 \\
\hline 1929 & 687 & 1960 & 1711 \\
\hline 1930 & 702 & $1961-65$ & 1921 \\
\hline 1931 & 717 & $1966-70$ & 2121 \\
\hline
\end{tabular}


Water-Supply Papers containing surface-waterquality data for Oklahoma

\begin{tabular}{cccc}
\hline $\begin{array}{c}\text { Water } \\
\text { Year }\end{array}$ & $\begin{array}{c}\text { Water-Supply } \\
\text { Paper }\end{array}$ & $\begin{array}{c}\text { Water } \\
\text { Year }\end{array}$ & $\begin{array}{c}\text { Water-Supply } \\
\text { Paper }\end{array}$ \\
\hline 1941 & 942 & 1957 & 1522 \\
1942 & 950 & 1958 & 1573 \\
1943 & 970 & 1959 & 1644 \\
1944 & 1022 & 1960 & 1744 \\
1945 & 1030 & 1961 & 1884 \\
1946 & 1050 & 1962 & 1944 \\
1947 & 1102 & 1963 & 1950 \\
1948 & 1133 & 1964 & 1957 \\
1949 & 1163 & 1965 & 1964 \\
1950 & 1188 & 1966 & 1994 \\
1951 & 1199 & 1967 & 2014 \\
1952 & 1252 & 1968 & 2096 \\
1953 & 1292 & 1969 & 2146 \\
1954 & 1352 & 1970 & 2156 \\
1955 & 1402 & 1971 & 2166 \\
1956 & 1452 & & \\
\hline
\end{tabular}

\section{Hydrologic Atlases}

Bergman, D.L., and Tortorelli, R.L., 1988, Flood of May 26-27, 1984 in Tulsa, Oklahoma: U.S. Geological Survey Hydrologic Investigations Atlas HA-707, 1 sheet.

Hart, D.L., Jr., 1966, Base of fresh ground water in southern Oklahoma: U.S. Geological Survey Hydrologic Investigations Atlas HA-223, scale 1:250,000, 2 sheets.

Krothe, N.C., Oliver, J.W., and Weeks, J.B., 1982, Dissolved solids and sodium in water from the High Plains aquifer in parts of Colorado, Kansas, Nebraska, New Mexico, Oklahoma, South Dakota, Texas, and Wyoming: U.S. Geological Survey Hydrologic Investigations Atlas HA-658, scale 1:2,500,000, 2 sheets.

Lohman, S.W., Burtis, V.M., and others, 1953a, Areas of principal ground-water investigations in the Arkansas, White, and Red River basins: U.S. Geological Survey Hydrologic Investigations Atlas $\mathrm{HA}-2$, scale 1:2,500,000, 2 sheets.

- 1953b, General availability of ground water and depth to water level in the Arkansas, White, and Red River basins: U.S. Geological Survey Hydrologic Investigations Atlas HA-3, scale 1:2,500,000.

Luckey, R.R., Gutentag, E.D., and Weeks, J.B., 1981, Water-level and saturated-thickness changes, predevelopment to 1980 , in the High Plains aquifer in parts of Colorado, 
Kansas, Nebraska, New Mexico, Oklahoma, South Dakota, Texas, and Wyoming: U.S. Geological Survey Hydrologic Investigations Atlas HA-652, scale 1:2,500,000, 2 sheets.

Morton, R.B., and Goemaat, R.L., 1972, Reconnaissance of the water resources of Beaver County, Oklahoma: U.S. Geological Survey Hydrologic Investigations Atlas HA-450, scale $1: 125,000,3$ sheets.

Sapik, D.B., and Goemaat, R.L., 1972, Reconnaissance of the ground-water resources of Cimarron County, Oklahoma: U.S. Geological Survey Hydrologic Investigations Atlas HA-373, scale 1:125,000, 3 sheets.

Weeks, J.B., and Gutentag, E.D., 1981, Bedrock geology, altitude of base, and 1980 saturated thickness of the High Plains aquifer in parts of Colorado, Kansas, Nebraska, New Mexico, Oklahoma, South Dakota, Texas, and Wyoming: U.S. Geological Survey Hydrologic Investigations Atlas HA-648, scale 1:2,500,000, 2 sheets.

Wood, P.R., and Hart, D.L., Jr., 1967, Availability of ground water in Texas County, Oklahoma: U.S. Geological Survey Hydrologic Investigations Atlas HA-250, scale 1:125,000, 3 sheets.

\section{Miscellaneous Geologic Investigations}

Morton, R.B., 1973, Preliminary investigations of the hydrogeology of the Middle Permian to Tertiary rocks of the Oklahoma Panhandle: U.S. Geological Survey Miscellaneous Geologic Investigations Map I-738, scale approximately 1:250,000, 2 sheets.

\section{Open-File Reports}

Andreasen, G.E., and Bromery, R.W., 1963, Total intensity aeromagnetic profiles over northeastern Oklahoma: U.S. Geological Survey Open-File Report 63-3, 1 map, in 2 parts.

Barclay, J.E., 1951, Ground-water levels in Oklahoma: U.S. Geological Survey Open-File Report 51-200, 3 p.

Bednar, G.A., and Waldrep, T.E., 1973, Fluvial sediment in Double Creek sub-watershed no. 5, Washington County, Oklahoma: U.S. Geological Survey Open-File Report 73-22, $38 \mathrm{p}$.

Bergman, D.L., and Huntzinger, T.L., 1981, Rainfall-runoff hydrographs and basin characteristics data for small streams in Oklahoma: U.S. Geological Survey Open-File Report $81-824,320$ p. 
Bingham, R.H., 1969, Ground-water levels in observation wells in Oklahoma, 1967-68: U.S. Geological Survey Open-File Report 69-335, 92 p.

Blumer, S.P., 1983, Sediment data for Mid-Arkansas and Upper Red River basins through 1980: U.S. Geological Survey Open-File Report 83-692, 799 p.

Blumer, S.P., and Alf, L.A., 1986, Hydrologic data for selected streams in the coal area of southeastern Oklahoma, July 1978 to September 1982: U.S. Geological Survey OpenFile Report 86-319, 337 p.

Blumer, S.P., and Hauth, L.D., 1984, Use and availability of continuous streamflow records in Oklahoma: U.S. Geological Survey Open-File Report 84-747, 23 p.

Blumer, S.P., and Scott, J.C., 1984, Hydrologic data for the Lehigh area, southeastern Oklahoma, May 1977 to January 1982: U.S. Geological Survey Open-File Report 84599,212 p.

Bohn, J.D., and Hoffman, G.L., 1970, A proposed streamflow data program for Oklahoma: U.S. Geological Survey Open-File Report 70-32, 44 p.

Breit, G.N, Mosier, E.L., Schlottmann, J.L., and Papp, C.S.E., 1990, Rock/water interactions and ground-water contamination in Permian rocks, Central Oklahoma aquifer: in Gough, L.P., ed., 1990, Environmental forum 1990: Geoscience investigations that emphasize chemical, physical, and biological ecosystem processes: U.S. Geological Survey Open-File report $90-288,21 \mathrm{p}$.

Breit, G.N., Rice, Cyndi, Esposito, Ken, and Schlottmann, J.L., 1990, Mineralogy and petrography of Permian rocks in the Central Oklahoma aquifer: U.S. Geological Survey Open-File Report 90-678, 50 p.

Buckner, H.D., and Kurklin, J.K., 1984, Floods in south-central Oklahoma and northcentral Texas: U.S. Geological Survey Open-File Report 84-065, 112 p.

Cady, R.C., 1937 (?), Ground water in Creek County, Oklahoma: U.S. Geological Survey Open-File Report 37-2, 12 p.

Carr, J.E., and Havens, J.S., 1976, Records of wells and water quality for the GarberWellington aquifer, northern Oklahoma and southern Logan Counties, Oklahoma: U.S. Geological Survey Open-File Report 76-619, 32 p.

Carr, J.E., and Marcher, M.V., 1977, A preliminary appraisal of the Garber-Wellington aquifer, southern Logan and northern Oklahoma Counties, Oklahoma: U.S. Geological Survey Open-File Report 77-278, 23 p. 
Christenson, S.C., Morton, R.B., Havens, J.S., and Fairchild, R.W., 1988, Geologic logs for selected deep wells in parts of Oklahoma, Texas, and New Mexico: U.S. Geological Survey Open-File Report 86-541, 161 p.

Christenson, S.C., and Parkhurst, D.L., 1987, Ground-water quality assessment of the Central Oklahoma Aquifer, Oklahoma: Project Description: U.S. Geological Survey OpenFile Report 87-235, $30 \mathrm{p}$.

Corley, R.K., and Huntzinger, T.L., 1979, Flood of August 27-28, 1977, West Cache Creek and Blue Beaver Creek, southwestern Oklahoma: U.S. Geological Survey Open-File Report 79-256, scale 1:24,000, 1 sheet.

D'Lugosz, J.J., and McClaflin, R.G., 1977, Hydrologic data for the Vamoosa aquifer, eastcentral Oklahoma: U.S. Geological Survey Open-File Report 77-487, 38 p.

- 1978, Geohydrology of the Vamoosa aquifer, east-central Oklahoma: U.S. Geological Survey Open-File Report 78-781,63 p.

Davis, L.V., 1955, Ground-water investigations in Oklahoma: U.S. Geological Survey OpenFile Report 55-36, 4 p.

Davis, L.V., and Schoff, S.L., 1948, Ground water in the Blanchard area, McClain County, Oklahoma: U.S. Geological Survey Open-File Report 48-80, 11 p.

Davis, R.E., and Christenson, S.C., 1981, Geohydrology and numerical simulation of the alluvium and terrace aquifer along the Beaver-North Canadian River from the Panhandle to Canton Lake, northwestern Oklahoma: U.S. Geological Survey Open-File Report 81-483, $42 \mathrm{p}$.

Davis, R.E., Christenson, S.C., and Blumer, S.P., 1980, Hydrologic data for the alluvium and terrace aquifer along the Beaver-North Canadian River from the Panhandle to Canton Lake, northwestern Oklahoma: U.S. Geological Survey Open-File Report 80-159, $77 \mathrm{p}$.

Davis, R.E., and Hart, D.L., Jr., 1978, Hydrologic data for the Antlers aquifer, southeastern Oklahoma: U.S. Geological Survey Open-File Report 78-1038, 24 p.

Dennis, P.E., 1950, Geology and ground-water hydrology of the Lake Hefner area in Oklahoma County, Oklahoma: U.S. Geological Survey Open-File Report 50-68, 19 p.

Dover, T.B., 1950, Mineral constituents in water and their significance: U.S. Geological Survey Open-File Report 50-69,6 p.

- 1957, Chemical quality of surface waters in the Arkansas River basin of Oklahoma: U.S. Geological Survey Open-File Report 57-40, 13 p. 
Dover, T.B., and Geurin, J.W., 1953(?), Changes in chemical quality of the Arkansas River in Oklahoma and Texas [1946-52]: U.S. Geological Survey Open-File Report 53-289, $33 \mathrm{p}$.

Ellis, A.J., 1918, Sources of water supply for the military establishments at Fort Sill, Oklahoma: U.S. Geological Survey Open-File Report 18-1, 11 p.

Fader, S.W., and Morton, R.B., 1975, Ground water in the Verdigris River basin, Kansas and Oklahoma: U.S. Geological Survey Open-File Report 75-365, 26 p.

- 1975, Ground water in the middle Arkansas River basin, Kansas and Oklahoma: U.S. Geological Survey Open-File Report 75-367, 44 p.

Fairchild, R.W., 1983, Hydrologic data for Arbuckle Mountain area, south-central Oklahoma: U.S. Geological Survey Open-File Report 83-28, 74 p.

Fairchild, R.W., Hanson, R.L., and Davis, R.E., 1982, Hydrology of the Arbuckle Mountain area: U.S. Geological Survey Open-File Report 82-775, 153 p.

Ferree, D.M., 1983, Ground-water quality data for Oklahoma, 1981: U.S. Geological Survey Open-File Report 83-686, 78 p.

— 1985, Ground-water quality data for Oklahoma-1982-84: U.S. Geological Survey Open-File Report 85-417, 43 p.

Goemaat, R.L., 1976, Ground-water levels in observation wells in Oklahoma, 1971-74: U.S. Geological Survey Open-File Report 76-664, 142 p.

— 1977a, Selected water-level records for western Oklahoma, 1950-75: U.S. Geological Survey Open-File Report 77-73, 94 p.

— 1977b, Ground-water levels in observation wells in Oklahoma, 1975: U.S. Geological Survey Open-File Report 77-238, 35 p.

— 1977c, Selected water-level records for western Oklahoma, 1975-76: U.S. Geological Survey Open-File Report 77-239, 50 p.

Goemaat, R.L., Mize, L.D., Madaj, A.J., and Spiser, D.E., 1986, Ground-water levels in observation wells in Oklahoma, period of record to March 1985: U.S. Geological Survey Open-File Report 86-314, 461 p.

Goemaat, R.L., Mize, D.L., and Spiser, D.E., 1983, Ground-water levels in observation wells in Oklahoma, 1980-82: U.S. Geological Survey Open-File Report 83-760, 604 p.

- 1984, Ground-water levels in observation wells in Oklahoma, 1982-83 climatic years: U.S. Geological Survey Open-File Report 84-472, 583 p. 
1985, Ground-water levels in observation wells in Oklahoma, 1983-84 climatic years: U.S. Geological Survey Open-File Report 85-87, 588 p.

Goemaat, R.L., and Spiser, D.E., 1978, Selected water-level records for Oklahoma, 1975-77:

U.S. Geological Survey Open-File Report 78-721, 58 p.

— 1979, Selected water-level records for Oklahoma, 1976-78: U.S. Geological Survey Open-File Report 79-1580, 48 p.

Goemaat, R.L., and Willard, C.C., 1983, Ground-water records for the area surrounding the Chickasaw National Recreation Area, Murray County, Oklahoma: U.S. Geological Survey Open-File Report 83-27, 13 p.

Gould, C.N., and Schoff, S.L., 1939, Geological report on water conditions at Platt National Park, Oklahoma: National Park Service Report 249, 38 p., 3 plates. (Also cataloged as U.S. Geological Survey Open-File Report 39-14)

Gutentag, E.D., and Weeks, J.B., 1980, Water table in the High Plains aquifer in 1978 in parts of Colorado, Kansas, Nebraska, New Mexico, Oklahoma, South Dakota, and Wyoming: U.S. Geological Survey Open-File Report 80-50, scale 1:2,500,000, 1 sheet.

Hanson, R.L., 1984, Droughts: U.S. Geological Survey Open-File Report 84-724, p. 773-811 , in Carla Kitzmiller, compiler, 1984, Proceeding of the geologic and hydrologic hazards training program: U.S. Geological Survey Open-File Report 84-760, 1,112 p.

Hanson, R.L., Scott, J.C., and Kurklin, J.K., 1983, Oklahoma: A summary of activities of the U.S. Geological Survey, Water Resources Division for 1983: U.S. Geological Survey Open-File Report 83-767, 104 p.

Hart, D.L., Jr., 1961, Ground water in the alluvium of Beaver Creek basin, Oklahoma: U.S. Geological Survey Open-File Report 61-59, 13 p. 1963, Ground-water levels in observation wells in Oklahoma, 1956-60: U.S. Geological Survey Open-File Report 63-150, 196 p.

1967, Ground-water levels in observation wells in Oklahoma, 1965-66: U.S. Geological Survey Open-File Report 67-285, 61 p.

Hart, D.L., Jr., and Davis, R.E., 1978, Geohydrology of the Antlers area, southeastern Oklahoma: U.S. Geological Survey open-file report, 35 p. [Released as Oklahoma Geological Survey Circular 81.]

Hart, D.L., Jr., Hoffman, G.L., and Goemaat, R.L., 1972, Records of water-level measurements in the Oklahoma Panhandle, 1971-72: U.S. Geological Survey Open-File Report $72-464,39 \mathrm{p}$. 
Hart, D.L., Jr., and others, 1971, Records of water-level measurements in wells in the Oklahoma Panhandle, 1966-70: U.S. Geological Survey Open-File Report 71-344, 66 p.

Hauth, L.D., 1985, Floods in central, southwest Oklahoma, October 17-23, 1983: U.S. Geological Survey Open-File Report 85-494, 17 p.

Havens, J.S., 1978a, Ground-water records for eastern Oklahoma, Part 2, water-quality records for wells, test-holes, and springs: U.S. Geological Survey Open-File Report 78-357, 139 p.

$1978 \mathrm{~b}$, Reconnaissance of ground water in the vicinity of the Wichita Mountains, southwestern Oklahoma: U.S. Geological Survey Open-File Report 78-857, 27 p.

- 1985, Hydrologic data: North Canadian River from Lake Overholser to Lake Eufaula, central Oklahoma: U.S. Geological Survey Open-File Report 84-808, 52 p.

1988a, Oklahoma, a summary of activities of the U.S. Geological Survey, Water Resources Division, in fiscal years 1986-87: U.S. Geological Survey Open-File Report $88-172,141$ p.

1988b, U.S. Geological Survey ground-water studies in Oklahoma: U.S. Geological Survey Open-File Report 88-140, 2 p.

- 1989, Bibliography of Oklahoma hydrology-Reports prepared by the U.S. Geological Survey and principal cooperating agencies, 1901-88: U.S. Geological Survey Open-File Report 89-33, $59 \mathrm{p}$.

Havens, J.S., and Bergman, D.L., 1976a, Ground-water records for southeastern Oklahoma-Part 1, Records of wells, test holes, and springs: U.S. Geological Survey Open-File Report 76-889, $59 \mathrm{p}$.

— 1976b, Ground-water records for northeastern Oklahoma-Part 1, Records of wells, test holes, and springs: U.S. Geological Survey Open-File Report 76-890, 100 p.

Hoffman, G.L., and Hart, D.L., Jr., 1973, Records of selected water wells and test holes in the Oklahoma Panhandle: U.S. Geological Survey Open-File Report 73-376, 59 p.

Hollowell, J.R., 1961a, Ground water in the alluvium of Elk Creek basin, Oklahoma: U.S. Geological Survey Open-File Report 61-65, 20 p. [Also published as Oklahoma Water Resources Board Bulletin 28, 15 p.]

- 1961b, Ground water in the vicinity of Roosevelt, Oklahoma: U.S. Geological Survey Open-File Report 61-67, 8 p.

Horak, W.F., and Stoner, J.D., 1988, Oklahoma ground-water quality: U.S. Geological Survey Open-File Report 87-746, 9 p. 
Huntzinger, T.L., 1978a, High-flow frequencies for selected streams in Oklahoma: U.S. Geological Survey Open-File Report 78-161, 30 p.

1978b, Low-flow characteristics of Oklahoma streams: U.S. Geological Survey OpenFile Report 78-166, 93 p.

- 1978c, Application of hydraulic and hydrologic data in urban storm water management: U.S. Geological Survey Open-File Report 78-414, 33 p.

Jacobsen, C.L., 1951, Memorandum on ground water from Mississippian rocks in the vicinity of Miami, Okla.: U.S. Geological Survey Open-File Report 51-120, 9 p., 1 fig.

Jacobsen, C.L., and Reed, E.W., 1951, Memorandum on results of pumping tests at Goodrich plant site, Miami, Okla.: U.S. Geological Survey Open-File Report 51-121, 11 p., 13 graphs, 3 figs.

Kurklin, J.K., 1979, Statistical summaries of surface-water-quality data for selected sites in Oklahoma, through the 1975 water year: U.S. Geological Survey Open-File Report 79-219, 185 p.

Laine, L.L., 1956, Surface-water resources of Polecat Creek basin, Oklahoma: U.S. Geological Survey Open-File Report 56-75, 20 p., 2 figs.

- 1958a, Surface-water resources of the Washita River basin in Oklahoma-magnitude, distribution, and quality of streamflow: U.S. Geological Survey Open-File Report 58$58,34 \mathrm{p}$.

1958b, Surface waters of North Boggy Creek basin in the Muddy Boggy Creek basin in Oklahoma, with a section on Chemical character of surface water, by T.B. Dover: U.S. Geological Survey Open-File Report 58-59, 34 p.

1959a, Surface waters of Little River basin in central Oklahoma, with a section on Chemical character of surface waters, by T.B. Dover: U.S. Geological Survey OpenFile Report 59-75, 47 p.

1959b, Surface waters of Illinois River basin in Arkansas and Oklahoma, with a section on Chemical character of surface waters, by T.B. Dover: U.S. Geological Survey OpenFile Report 59-76, 65 p.

1959c, Correlative estimates of discharge for Verdigris River (tributary to Arkansas River) near Tenapah, Oklahoma, for year ending September 30, 1938: U.S. Geological Survey Open-File Report 59-77, 2 p.

1962, Surface waters of Cottonwood Creek in the Cimarron River basin in central Oklahoma, with a section on Chemical quality of surface waters, by R.P. Orth: U.S. Geological Survey Open-File Report 62-75, 41 p. 
— 1963, Surface water of Kiamichi River basin in southeastern Oklahoma, with a section on Quality of water, by T.R. Cummings: U.S. Geological Survey open-file report, 39 p.

Laine, L.L., and Murphy, J.J., 1962, Surface water of Beaver Creek basin in south-central Oklahoma: U.S. Geological Survey Open-File Report 62-162, 28 p.

Laine, L.L., Schoff, S.L., and Dover, T.B., 1951, Public water supplies in Oklahoma: U.S. Geological Survey Open-File Report 51-201, 110 p.

Leonard, A.R., 1960, Ground water in Oklahoma: U.S. Geological Survey Open-File Report 60-166, $12 \mathrm{p}$.

Leonard, A.R., Davis, L.V., and Stacy, B.L., 1958, Ground water in the alluvial deposits of the Washita River and its tributaries in Oklahoma: U.S. Geological Survey Open-File Report 58-63, 13 p.

MacLachlan, M.E., 1964, The Anadarko Basin (of parts of Oklahoma, Texas, Kansas, and Colorado): U.S. Geological Survey Open-File Report 64-112, 75 p.

Mize, L.D., 1975, Statistical summaries of streamflow records, Oklahoma, through 1974: U.S. Geological Survey Open-File Report 75-684, 399 p.

Moore, R.L., 1972, Ground-water levels in observation wells in Oklahoma, 1969-70: U.S. Geological Survey Open-File Report 72-463, 85 p.

Morton, R.B., 1980, Digital-model projection of saturated thickness and recoverable water in the Ogallala aquifer, Texas County, Oklahoma: U.S. Geological Survey Open-File Report 79-565, 34 p.

Morton, R.B., and Fader, S.W., 1975, Ground water in the Grand (Neosho) River basin, Kansas and Oklahoma: U.S. Geological Survey Open-File Report 75-366, 35 p.

Mosier, E.L., and others, 1990, Analyses of subsurface Permian rock samples from the Central Oklahoma aquifer: U.S. Geological Survey Open-File Report 90-456, 65 p.

Parkhurst, D.L., 1987, Chemical analyses of water samples from the Picher mining area, northeast Oklahoma and southeast Kansas: U.S. Geological Survey Open-File Report $87-453,43 \mathrm{p}$.

Parkhurst, D.L., Christenson, S.C., and Schlottmann, J.L., 1989, Ground-water quality assessment of the central Oklahoma aquifer, Oklahoma-Analysis of available waterquality data through 1987: U.S. Geological Survey Open-File Report 88-728, 80 p.

Parkhurst, D.L., Doughten, Michael, and Hearn, P.P., 1988, Chemical analyses of stream sediment in the Tar Creek basin of the Picher mining area, northeast Oklahoma: U.S. Geological Survey Open-File Report 88-469, 13 p. 
Playton, S.J., and Davis, R.E., 1977, Preliminary report on the quality of water in abandoned zinc mines in northeastern Oklahoma and southeastern Kansas: U.S. Geological Survey Open-File Report 77-163, 36 p.

Playton, S.J., Davis, R.E., and McClaflin, R.G., 1980, Chemical quality of water in abandoned zinc mines in northeastern Oklahoma and southeastern Kansas: U.S. Geological Survey Open-File Report 78-294, 67 p. [Published as Oklahoma Geological Survey Circular 82.]

Schoff, S.L., 1948a, Ground-water conditions in the vicinity of Enid, Oklahoma: U.S. Geological Survey Open-File Report 48-81, $4 \mathrm{p}$.

— 1948b, Ground-water in the Beggs area, Okmulgee County, Oklahoma: U.S. Geological Survey Open-File Report 48-82, 7 p.

— 1948c, Ground-water available in the Davenport area [Lincoln County], Oklahoma: U.S. Geological Survey Open-File Report 48-83, 6 p.

— 1948d, Ground water in the Anadarko area [Caddo County], Oklahoma: U.S. Geological Survey Open-File Report 48-84, 7 p.

Schoff, S.L., and Davis, L.V., 1948, Ground water in the Blanchard area, McClain County, Oklahoma: U.S. Geological Survey open-file report.

Schoff, S.L., Dott, R.H., and Lalicker, D.G., 1941, Contamination of Lake Wewoka and freshwater sands by disposal of oil-well brines near Wewoka, Seminole County, Oklahoma: U.S. Geological Survey Open-File Report 41-32, 8 p.

Slack, L.J., and Blumer, S.P., 1984, Physical and chemical characteristics of water in coalmine ponds, eastern Oklahoma, June to November 1977-81: U.S. Geological Survey Open-File Report 84-446, 185 p. [Published as Oklahoma Geological Survey Special Publication 87-2.]

Stacy, B.L., 1960, Ground water in the alluvial deposits of Cottonwood Creek basin, Oklahoma: U.S. Geological Survey Open-File Report 60-130, 8 p.

- 1961, Ground-water resources of the alluvial deposits of the Canadian River valley near Norman, Oklahoma: U.S. Geological Survey Open-File Report 61-177, 61 p.

Stoner, J.D., 1977, Index of published surface-water-quality data for Oklahoma, 1946-1975: U.S. Geological Survey Open-File Report 77-204, 212 p.

- 1980, Reconnaissance of polychlorinated biphenyls in the Arkansas River between Muskogee and Webbers Falls Lock and Dam, Oklahoma: U.S. Geological Survey OpenFile Report 80-216, 6 p. 
Tanaka, H.H., 1960, Water-level and water-level change maps for the irrigation area in the Rush Springs sandstone in Caddo County and adjacent area: U.S. Geological Survey Open-File Report 60-138, 4 maps.

Tanaka, H.H., Hart, D.L., Jr., and Knott, R.K., 1965a, Ground-water data of selected test holes and wells along the Arkansas River in Muskogee County, Oklahoma: U.S. Geological Survey Open-File Report 65-155, 287 p.

— 1965b, Ground-water data of selected test holes and wells along the Verdigris River in Wagoner and Rogers Counties Oklahoma: U.S. Geological Survey Open-File Report 65-156, $411 \mathrm{p}$.

- 1965c, Ground-water data of selected test holes and wells along the Arkansas River in Sequoyah County, Oklahoma: U.S. Geological Survey Open-File Report 65-157, 238 p.

- 1965d, Ground-water data of selected test holes and wells along the Arkansas River in LeFlore and Haskell Counties, Oklahoma: U.S. Geological Survey Open-File Report 65-158, $236 \mathrm{p}$.

Theis, C.V., 1934, Preliminary geological report on the Salt Plains reservoir site [Alfalfa County], Oklahoma: U.S. Geological Survey Open-File Report 34-2, 15 p.

Thomas, W.O., Jr., and Corley, R.K., 1974, Floodflows from small drainage areas in Oklahoma: Progress report and data compilation: U.S. Geological Survey Open-File Report 74-1099, $50 \mathrm{p}$.

Tortorelli, R.L., Huntzinger, T.L., Bergman, D.L., and Patneaude, A.L., Jr., 1983, Urban flood analysis in Oklahoma City, Oklahoma: U.S. Geological Survey Open-File Report 83-26, $94 \mathrm{p}$.

Turner, S.F., 1931, Report on water supply for the proposed Southwestern Reformatory at . El Reno, Oklahoma: U.S. Geological Survey Open-File Report 31-1, 20 p.

U.S. Geological Survey, 1945a, Water facts for Oklahoma: U.S. Geological Survey Open-File Report 45-110, 35 p.

- 1945b, Chemical analyses of surface waters in Oklahoma, September-December 1944: U.S. Geological Survey Open-File Report 45-111, 51 p.

- 1953(?), Summary of annual records of chemical quality of the Arkansas River in Oklahoma and Arkansas, 1945-1952: U.S. Geological Survey Open-File Report 53-288, $38 \mathrm{p}$.

1966, Ground water in the Cimarron River basin, New Mexico, Colorado, Kansas, and Oklahoma: U.S. Geological Survey Open-File Report 66-159, 51 p. 
— 1985, Oklahoma: A summary of activities of the U.S. Geological Survey, Water Resources Division, for 1985: U.S. Geological Survey Open-File Report 85-328, 129 p.

Ward, P.E., 1961, Geology and ground-water features of salt springs, seeps, and plains in the Arkansas and Red River basins of western Oklahoma and adjacent parts of Kansas and Texas: U.S. Geological Survey Open-File Report 63-132, 94 p.

Weiss, D.L., and Sullivan, C.L., 1958(?), Floods of April-June 1957 in Oklahoma and western Arkansas: U.S. Geological Survey Open-File Report 57-127, 21 p.

Westfall, A.O., 1962a, Surface waters of Elk Creek basin in southwestern Oklahoma: U.S. Geological Survey Open-File Report 63-138, 18 p.

— 1962b, Surface waters of Otter Creek basin in southwestern Oklahoma, it with a section on Chemical quality of surface water, by J.J. Murphy: U.S. Geological Survey Open-File Report 62-155, 37 p.

1963a, Surface water of Muddy Boggy River basin in south-central Oklahoma, it with a section on Quality of water, by T.R. Cummings: U.S. Geological Survey Open-File Report 63-148, $71 \mathrm{p}$.

— 1963b, Surface water of Little River basin in southeastern Oklahoma, it with a section on Quality of water, by R.P. Orth: U.S. Geological Survey Open-File Report 63-151, $66 \mathrm{p}$.

Westfall, A.O., and Patterson, J.L., 1964, Floods in Oklahoma, magnitude and frequency: U.S. Geological Survey Open-File Report 64-170, 105 p.

Wood, P.R., 1965a, Records of ground-water levels and effects of pumping in the Ardmore well-field area, Carter County, Oklahoma: U.S. Geological Survey Open-File Report 65-176, $14 \mathrm{p}$.

— 1965b, Ground-water levels in observation wells in Oklahoma, 1963-64: U.S. Geological Survey Open-File Report 65-184, 82 p.

Wood, P.R., and Moeller, M.D., 1964, Ground-water levels in observation wells in Oklahoma, 1961-62: U.S. Geological Survey Open-File Report 64-169, 119 p.

\section{Water-Resources Investigations Reports}

Bingham, R.H., Bergman, D.L., and Thomas, W.O., Jr., 1974, Flood of October 1973 in Enid and vicinity, north-central Oklahoma: U.S. Geological Survey Water-Resources Investigations $27-74$, scale 1:250,000, 1:126,720, 2 sheets. 
Christenson, S.C., 1983, Numerical simulation of the alluvium and terrace aquifer along the North Canadian River from Canton Lake to Lake Overholser, central Oklahoma: U.S. Geological Survey Water Resources Investigations Report 83-4076, 36 p.

Feder, G.L., and Krothe, N.C., 1981, Results of a reconnaissance water-quality sampling program of the Ogallala aquifer in Colorado, Kansas, Nebraska, Oklahoma, South Dakota, and Texas: U.S. Geological Survey Water-Resources Investigations 81-65, $7 \mathrm{p}$.

Hart, D.L., Jr., Hoffman, G.L., and Goemaat, R.L., 1976, Geohydrology of the Oklahoma Panhandle, Beaver, Cimarron, and Texas Counties: U.S. Geological Survey WaterResources Investigation 25-75, $62 \mathrm{p}$.

Havens, J.S., 1982a, Altitude and configuration of the 1980 water table in the High Plains regional aquifer, northwestern Oklahoma: U.S. Geological Survey Water-Resources Investigations Open-File Report 81-100, scale 1:250,000, 2 sheets.

- 1982b, Altitude and configuration of the predevelopment water table in the High Plains regional aquifer, northwestern Oklahoma: U.S. Geological Survey Water-Resources Investigations Open-File Report $81-275$, scale 1:250,000, 2 sheets.

— 1982c, Saturated thickness of the High Plains regional aquifer in 1980, northwestern Oklahoma: U.S. Geological Survey Water-Resources Investigations Open-File Report $81-760$, scale $1: 250,000,2$ sheets.

1982d, Generalized altitude and configuration of the base of the High Plains regional aquifer, northwestern Oklahoma: U.S. Geological Survey Water-Resources Investigations Open-File Report 81-1117, scale 1:250,000, 2 sheets.

- 1983, Water-level changes in the High Plains regional aquifer, northwestern Oklahoma, predevelopment to 1980: U.S. Geological Survey Water-Resources Investigations Report 83-4073, scale $1: 500,000,1$ sheet. 1989, Geohydrology of the alluvial and terrace deposits of the North Canadian River from Oklahoma City to Eufaula Lake, central Oklahoma: U.S. Geological Survey WaterResources Investigations Report 88-4234, 32 p., 12 plates.

Havens, J.S., and Christenson, S.C., 1983, Numerical simulation of the High Plains regional aquifer, northwestern Oklahoma: U.S. Geological Survey Water-Resources Investigations Report 83-4269, $27 \mathrm{p}$.

Heimann, D.C., and Tortorelli, R.L., 1988, Statistical summaries of streamflow records in Oklahoma in parts of Arkansas, Kansas, Missouri, and Texas through 1984: U.S. Geological Survey Water-Resources Investigations Report 87-4205, 387 p.

Heimes, F.J., and Luckey, R.R., 1982, Method for estimating historical irrigation requirements from ground water in the High Plains in parts of Colorado, Kansas, Nebraska, 
New Mexico, Oklahoma, South Dakota, Texas, and Wyoming: U.S. Geological Survey Water-Resources Investigations Report, 82-40, 64 p.

Krothe, N.C., and Oliver, J.W., 1982, Sulfur isotopic composition and water chemistry in water from the High Plains aquifer, Oklahoma Panhandle and southwestern Kansas: U.S. Geological Survey Water-Resources Investigations 82-12, 27 p.

Kurklin, J.K., 1985, Water quality in the Blue Creek arm of Lake Eufaula and Blue Creek, Oklahoma, March-October 1978: U.S. Geological Survey Water-Resources Investigations Report 85-4039, 91 p. 1990, Water quality in Gaines Creek and Gaines Creek arm of Eufaula Lake, Oklahoma: U.S. Geological Survey Water-Resources Investigations Report 86-4169, 97 p.

Marcher, M.V., Bergman, D.L., Slack, L.J., and Blumer, S.P., 1984, Hydrology of Area 41, Western Region, Interior Coal Province, Oklahoma and Arkansas: U.S. Geological Survey Water-Resources Investigations Open-File Report 84-129, 86 p.

Marcher, M.V., Bergman, D.L., Stoner, J.D., and Blumer, S.P., 1981, Preliminary appraisal of the hydrology of the Blocker area, Pittsburg County, Oklahoma: U.S. Geological Survey Water-Resources Investigations Report 81-1187, 48 p.

1983a, Preliminary appraisal of the hydrology of the Rock Island area, Le Flore County, Oklahoma: U.S. Geological Survey Water-Resources Investigations Report 83-4013, $35 \mathrm{p}$.

1983b, Preliminary appraisal of the hydrology of the Red Oak area, Latimer County, Oklahoma: U.S. Geological Survey Water-Resources Investigations Report 83-4166. $44 \mathrm{p}$.

Marcher, M.V., Huntzinger, T.L., Stoner, J.D., and Blumer, S.P., 1983, Preliminary appraisal of the hydrology of the Stigler area, Haskell County, Oklahoma: U.S. Geological Survey Water-Resources Investigations Report 82-4099, 37 p.

Marcher, M.V., Kenny, J.F., and others, 1984, Hydrology of Area 40, Western Region, Interior Coal Province, Kansas, Oklahoma, and Missouri: U.S. Geological Survey WaterResources Investigations Open-File Report 83-266, 97 p.

Parkhurst, R.S., and Christenson, S.C., 1987, Selected chemical analyses of water from formations of Mesozoic and Paleozoic age in parts of Oklahoma, northern Texas, and Union County, New Mexico: U.S. Geological Survey Water-Resources Investigations Report 86-4355, 222 p. 
Rea, A.H., and Scott, J.C., 1990, A computer program to determine map coordinates from public land-survey coordinates [abs.]: in Balthrop, B.H, and Baker, E.G., 1990, U.S. Geological Survey national computer technology meeting: Program and abstracts, May 7-11, 1990: U.S. Geological Survey Open-File Report 90-161, p. 33.

Reed, J.E., 1982, Preliminary projections of the effects of chloride-control structures on the Quaternary aquifer at Great Salt Plains, Oklahoma: U.S. Geological Survey WaterResources Investigations Report 80-120, 45 p.

Sauer, V.B., 1974a, Flood characteristics of Oklahoma streams: U.S. Geological Survey Water-Resources Investigations 52-73, $301 \mathrm{p}$.

1974b, An approach to estimating flood frequency for urban areas in Oklahoma: U.S. Geological Survey Water-Resources Investigations 23-74, 10 p.

Scott, J.C., 1989, A computerized data-base system for land-use and land-cover data collected at ground-water sampling sites in the pilot National Water-Quality Assessment program: U.S. Geological Survey Water-Resources Investigations Report 89-4172, $139 \mathrm{p}$.

1990a, A statistical processor for analyzing simulations made using the modular finitedifference ground-water flow model: U.S. Geological Survey Water-Resources Investigations Report 89-4159, 218 p.

1 1990b, Computerized stratified random site-selection approaches for design of a groundwater-quality sampling network: U.S. Geological Survey Water-Resources Investigations Report 90-4101, 109 p.

Slack, L.J., 1983, Hydrology of an abandoned coal-mining area near McCurtain, Haskell County, Oklahoma: U.S. Geological Survey Water-Resources Investigations Report 83-4202, $117 \mathrm{p}$.

Stoner, J.D., 1981a, Water type and suitability of Oklahoma surface waters for public supply and irrigation, Part 1; Arkansas River mainstem and Verdigris, Neosho, and Illinois River basins through 1978: U.S. Geological Survey Water-Resources Investigations 81-33, 297 p.

1981b, Water type and suitability of Oklahoma surface waters for public supply and irrigation, Part 2; Salt Fork Arkansas and Cimarron River basins through 1978: U.S. Geological Survey Water-Resources Investigations 81-39, $150 \mathrm{p}$.

1981c, Water type and suitability of Oklahoma surface waters for public supply and irrigation, Part 3; Canadian, North Canadian, and Deep Fork River basins through 1979: U.S. Geological Survey Water-Resources Investigations 81-80, 210 p. 
1982a, Water type and suitability of Oklahoma surface waters for public supply and irrigation, Part 4; Red River mainstem and North Fork Red River through 1979: U.S. Geological Survey Water-Resources Investigations 82-9, $235 \mathrm{p}$.

1982b, Water type and suitability of Oklahoma surface waters for public supply and irrigation, Part 5; Washita River basin through 1979: U.S. Geological Survey WaterResources Investigations 82-29, $150 \mathrm{p}$.

- 1984, Estimate of self-supplied domestic water use in Oklahoma during 1980: U.S. Geological Survey Water-Resources Investigations Report 83-4223, 20 p.

- 1985, Reported withdrawals and estimated use of water in Oklahoma during 1982: U.S. Geological Survey Water-Resources Investigations Report 85-4084, 96 p.

Thomas, W.O., Jr., 1976, Techniques for estimating flood depths for Oklahoma streams: U.S. Geological Survey Water-Resources Investigations 2-76, $170 \mathrm{p}$.

Thomas, W.O., Jr., and Corley, R.K., 1973, 1971-72 Floods of Glover Creek and Little River in southeastern Oklahoma: U.S. Geological Survey Water-Resources Investigations $5-73$, scale $1: 24,000,2$ sheets.

_ 1977, Techniques for estimating flood discharges for Oklahoma streams: U.S. Geological Survey Water-Resources Investigations 77-54, $170 \mathrm{p}$.

Tortorelli, R.L., and Bergman, D.L., 1984, Techniques for estimating flood peak discharges for unregulated streams and streams regulated by small floodwater retarding structures in Oklahoma: U.S. Geological Survey Water-Resources Investigations Report 84-4358, $85 \mathrm{p}$.

Weeks, J.B., 1978, Plan of study for the High Plains regional aquifer systems analysis in parts of Colorado, Kansas, New Mexico, Oklahoma, South Dakota, Texas, and Wyoming: U.S. Geological Survey Water-Resources Investigations 78-70, 28 p.

\section{Federal Emergency Management Flood Insurance Studies}

Bergman, D.L., 1980a, City of Sallisaw, Oklahoma: Washington D.C., Federal Emergency Management Agency Flood Insurance Study, community number 400199, 23 p.

1980b, City of Edmond, Oklahoma: Washington D.C., Federal Emergency Management Agency Flood Insurance Study, community number 400252, 41 p.

— 1980c, City of the Village, Oklahoma: Washington D.C., Federal Emergency Management Agency Flood Insurance Study, community number 400420, 15 p. 
- 1982, City of Nichols Hills, Oklahoma: Washington D.C., Federal Emergency Management Agency Flood Insurance Study, community number 400423, 15 p.

Bergman, D.L., and Walton, C., 1979, City of Duncan, Oklahoma: Washington D.C., Federal Emergency Management Agency Flood Insurance Study, community number 400202, 24 p.

Corley, R.K., 1980, City of Ponca City, Oklahoma: Washington D.C., Federal Emergency Management Agency Flood Insurance Study, community number 400080, 23 p.

Huntzinger, T.L., 1979a, City of Enid, Oklahoma: Washington D.C., Federal Emergency Management Agency Flood Insurance Study, community number 400062, 31 p.

— 1979b, City of McAlester, Oklahoma: Washington D.C., Federal Emergency Management Agency Flood Insurance Study, community number 400170, 22 p.

- 1980a, City of Mustang, Oklahoma: Washington D.C., Federal Emergency Management Agency Flood Insurance Study, community number 400409, 15 p.

— 1980b, Town of Nicoma Park, Oklahoma: Washington D.C., Federal Emergency Management Agency Flood Insurance Study, community number 400424, 15 p.

- 1981a, Town of North Enid, Oklahoma: Washington D.C., Federal Emergency Management Agency Flood Insurance Study, community number 400425, 14 p.

1981b, City of Choctaw, Oklahoma: Washington D.C., Federal Emergency Management Agency Flood Insurance Study, community number 400357, 23 p.

- 1981c, City of Midwest City, Oklahoma: Washington D.C., Federal Emergency Management Agency Flood Insurance Study, community number 400405, 21 p.

Huntzinger, T.L., and Tortorelli, R.L., 1980a, City of Spencer, Oklahoma: Federal Emergency Management Agency Flood Insurance Study, community number 400412, 15 p.

— 1980b, City of Warr Acres, Oklahoma: Washington D.C., Federal Emergency Management Agency Flood Insurance Study, community number 400449, 13 p.

- 1981a, Town of Jones, Oklahoma: Washington D.C., Federal Emergency Management Agency Flood Insurance Study, community number 400141, 20 p.

— 1981b, Town of Valley Brook, Oklahoma: Washington D.C., Federal Emergency Management Agency Flood Insurance Study, community number 400445, 13 p.

Huntzinger, T.L., Tortorelli, R.L., and Bergman, D.L., 1982, City of Oklahoma City, Oklahoma: Washington D.C., Federal Emergency Management Agency Flood Insurance Study, community number 405378, 194 p. 
Tortorelli, R.L., 1982, Town of Piedmont, Oklahoma: Washington D.C., Federal Emergency Management Agency Flood Insurance Study, community number 400027, 17 p.

1988, Limited detail flood insurance study, City of Tishomingo, Johnston County, Oklahoma: Washington, D.C., Federal Emergency Management Agency Flood Insurance Study, community number 400077, 11p.

- 1989, Limited detail flood insurance study, Town of Pocola, Le Flore County, Oklahoma: Washington, D.C., Federal Emergency Management Agency Flood Insurance Study, community number 400432, 11p.

1990, Limited detail flood insurance study, Bryan County, and incorporated areas: Washington, D.C., Federal Emergency Management Agency Flood Insurance Study, community number 400482,22 p.

Tortorelli, R.L., Huntzinger, T.L., and Bergman, D.L., 1982, Oklahoma County, Oklahoma: Washington D.C., Federal Emergency Management Agency Flood Insurance Study, community number $400466,21 \mathrm{p}$.

\section{Water-Resources Data Reports}

Hauth, L.D., Kurklin, J.K., and Walters, D.M., 1985, Water resources data for Oklahoma, water year 1983: U.S. Geological Survey Water-Data Report OK-83-1, 286 p.

— 1986, Water resources data, Oklahoma, water year 1984: U.S. Geological Survey Water-Data Report OK-84-1, 302 p.

18 1988, Water resources data, Oklahoma, water year 1986: U.S. Geological Survey Water-Data Report OK-86-1, 316 p.

Hauth, L.D., Kurklin, J.K., Walters, D.M., and Coffey, T.E., 1987, Water resources data, Oklahoma, water year 1985: U.S. Geological Survey Water-Data Report OK-85-1, $302 \mathrm{p}$.

Hauth, L.D., Kurklin, J.K., Walters, D.M., and Ferree, D.M., 1984, Water resources data, Oklahoma, water year 1982: U.S. Geological Survey Water-Data Report OK-82-1, 336 p.

Hauth, L.D., Walters, D.M., Coffey, T.E., and White, D.K., 1989, Water resources data, Oklahoma, water year 1987: U.S. Geological Survey Water-Data Report OK-87-1, 324 p.

1990, Water resources data, Oklahoma, water year 1988: U.S. Geological Survey Water-Data Report OK-88-1, 326 p. 
U.S. Geological Survey, 1961-64, Surface-water records of Oklahoma. (One volume for each year).

— 1964, Quality-of-water records of Oklahoma, 62 p.

— 1965-74, Water resources data for Oklahoma-Part 1, Surface-water records; Part 2, Water-quality records. (One volume of each for each year).

- 1976, Water resources data for Oklahoma, water year 1975: U.S. Geological Survey Water-Data Report OK-75-1, 528 p.

_ 1977a, Water resources data for Oklahoma, water year 1976, Volume 1, Arkansas River basin: U.S. Geological Survey Water-Data Report OK-76-1, 513 p.

— 1977b, Water resources data for Oklahoma, water year 1976, Volume 2, Red River basin: U.S. Geological Survey Water-Data Report OK-76-2, 216 p.

— 1978a, Water resources data for Oklahoma, water year 1977, Volume 1, Arkansas River basin: U.S. Geological Survey Water-Data Report OK-77-1, 542 p.

— 1978b, Water resources data for Oklahoma, water year 1977, Volume 2, Red River basin: U.S. Geological Survey Water-Data Report OK-77-2, 235 p.

— 1979a, Water resources data for Oklahoma, water year 1978, Volume 1, Arkansas River basin: U.S. Geological Survey Water-Data Report OK-78-1, 523 p.

- 1979b, Water resources data for Oklahoma, water year 1978, Volume 2, Red River basin: U.S. Geological Survey Water-Data Report OK-78-2, 249 p.

- 1981a, Water resources data for Oklahoma, water year 1979, Volume 1, Arkansas River basin: U.S. Geological Survey Water-Data Report OK-79-1, 629 p.

— 1981b, Water resources data for Oklahoma, water year 1979, Volume 2, Red River basin: U.S. Geological Survey Water-Data Report OK-79-2, 249 p.

— 1982, Water resources data for Oklahoma, water year 1980, Volume 1: U.S. Geological Survey Water-Data Report OK-80-1, 613 p.

- 1983, Water resources data-Oklahoma, water year 1981: U.S. Geological Survey Water-Data Report OK-81-1, 546 p.

1984, Water resources data-Oklahoma, water year 1982: U.S. Geological Survey Water-Data Report OK-82-1, 336 p. 


\section{Circulars}

Irwin, J.H., and Morton, R.B., 1969, Hydrogeologic information on the Glorieta Sandstone and Ogallala Formation in the Oklahoma Panhandle and adjoining areas as related to underground waste disposal: U.S. Geological Survey Circular 630, 26 p.

\section{Annual Reports}

Johnson, W.D., 1901, The High Plains and their utilization: U.S. Geological Survey Twentyfirst Annual Report, IV, p. 601-741.

1902, The High Plains and their utilization: U.S. Geological Survey Twenty-second Annual Report, IV, p. 631-639.

\section{Miscellaneous Reports}

Miser, H.D., 1954, Geologic map of Oklahoma: Oklahoma Geological Survey and U.S. Geological Survey, scale 1:500,000.

U.S. Geological Survey, 1976, Hydrologic Unit Map of Oklahoma-1974: Scale 1:500,000, 1 sheet.

— 1977, Water-resources investigations in Oklahoma, 1976: U.S. Geological Survey miscellenous report, $6 \mathrm{p}$.

\section{OKLAHOMA WATER RESOURCES BOARD}

\section{Bulletins}

Barclay, J.E., and Burton, L.C., 1953, Ground-water resources of the terrace deposits and alluvium of western Tillman County, Oklahoma: Oklahoma Planning and Resources Board Division of Water Resources Bulletin 12, $71 \mathrm{p}$.

Burton, L.C., 1965, Ground water in terrace deposits of central Beckham County, Oklahoma: Oklahoma Water Resources Board Bulletin 25, 30 p.

Cummings, T.R., 1963, Chemical character of surface waters in Oklahoma 1957-58: Oklahoma Water Resources Board Bulletin 19, 165 p. 
- 1964, Chemical character of surface waters in Oklahoma 1958-59: Oklahoma Water Resources Board Bulletin 20, 133 p.

1965a, Chemical character of surface waters in Oklahoma 1960-61: Oklahoma Water Resources Board Bulletin 23, 178 p.

— 1965b, Chemical character of surface waters in Oklahoma 1961-62: Oklahoma Water Resources Board Bulletin 24, 203 p.

- 1966a, Chemical character of surface waters in Oklahoma 1959-60: Oklahoma Water Resources Board Bulletin 22, 167 p.

- 1966b, Chemical character of surface waters in Oklahoma 1962-63: Oklahoma Water Resources Board Bulletin 30, 200 p.

Dover, T.B., 1953a, Chemical character of surface waters in Oklahoma 1950-51: Oklahoma Planning and Resources Board Division of Water Resources Bulletin 7, 88 p.

- 1953b, Chemical character of public water supplies of Oklahoma 1953: Oklahoma Planning and Resources Board Division of Water Resources Bulletin 8, 47 p.

- 1954, Chemical character of surface waters of Oklahoma 1951-52: Oklahoma Planning and Resources Board Division of Water Resources Bulletin 10, 115 p.

- 1956, Chemical character of surface waters of Oklahoma 1953-54: Oklahoma Planning and Resources Board Division of Water Resources Bulletin 14, 141 p.

- 1958, Chemical character of surface waters of Oklahoma 1954-55: Oklahoma Water Resources Board Bulletin 15, 117 p.

- 1959, Chemical character of surface waters of Oklahoma 1955-56: Oklahoma Water Resources Board Bulletin 16, 144 p.

Dover, T.B., and Murphy, J.J., 1955, A reconnaissance of the chemical and physical quality of Pryor Creek in the vicinity of Pryor, Oklahoma: Oklahoma Planning and Resources Board Division of Water Resources Bulletin 13, 32 p.

Gilbert, C.R., 1959, Hydrologic and physical data for Sandstone Creek watershed in western Oklahoma 1951-56: Oklahoma Water Resources Board Bulletin 17, 124 p.

Hart, D.L., Jr., 1965, Ground water in the alluvial deposits of the Washita River between Clinton and Anadarko, Oklahoma: Oklahoma Water Resources Board Bulletin 26, 23 p.

Hollowell, J.R., 1965a, Ground water in the alluvium of Otter Creek basin, Oklahoma: Oklahoma Water Resources Board Bulletin 27, 15 p. 
- 1965b, Ground water in the alluvium of Elk Creek basin, Oklahoma: Oklahoma Water Resources Board Bulletin 28, 12 p.

Murphy, J.J., 1955, Chemical character of surface waters of Oklahoma 1952-53: Oklahoma Planning and Resources Board Division of Water Resources Bulletin 11, 128 p.

Pate, C.O., Murphy, J.J., and Orth, R.P., 1961, Chemical character of surface waters of Oklahoma 1956-57: Oklahoma Water Resources Board Bulletin 18, 138 p.

Reed, E.W., Mogg, J.L., Barclay, J.E., and Peden, G.H., 1952, Ground-water resources of the terrace deposits along the northeast side of the Cimarron River in Alfalfa, Garfield, Kingfisher, and Major Counties, Oklahoma: Oklahoma Planning and Resources Board Division of Water Resources Bulletin 9, $101 \mathrm{p}$.

Steele, C.E., and Barclay, J.E., 1965, Ground-water resources of Harmon County and adjacent parts of Greer and Jackson Counties, Oklahoma: Oklahoma Water Resources Board Bulletin 29, 96 p.

Walling, I.W., 1949, Chemical character of surface waters in the Washita River basin of Oklahoma, 1946-47: Oklahoma Planning and Resources Board Division of Water Resources Bulletin 4, 31 p.

- 1952, Chemical character of surface waters in Oklahoma 1949-50: Oklahoma Planning and Resources Board Division of Water Resources Bulletin 6, 70 p.

Walling, I.W., Schoff, S.L., and Dover, T.B., 1951, Chemical character of surface waters in Oklahoma 1946-49: Oklahoma Planning and Resources Board Division of Water Resources Bulletin 5, 180 p.

Wood, P.R., and Stacy, B.L., 1965, Geology and ground-water resources of Woodward County, Oklahoma: Oklahoma Water Resources Board Bulletin 21, 114 p.

\section{Hydrologic Investigation}

Wickersham, Ginia, 1979, Ground water resources of the southern part of the GarberWellington ground water basin, in Cleveland and southern Oklahoma Counties and parts of Pottawatomie County, Oklahoma: Oklahoma Water Resources Board Hydrologic Investigations Publication 86, 3 sheets. 


\section{Miscellaneous Reports}

Laine, L.L., 1940(?), Provisional report on flood of September 1940, and miscellaneous discharge measurements, in Dam failure at Cleveland caused by storm of September 4, 1940: Oklahoma Planning and Resources Board Division of Water Resources, p. 7-18.

Reed, E.W., Oakland, G.L., and Jacobsen, C.L., 1945, Oklahoma water: Oklahoma Planning and Resources Board Division of Water Resources, 145 p.

U.S. Geological Survey, 1945, Oklahoma water-Quantity, occurrence, and quality of surface and ground water: Oklahoma Planning and Resources Board, 145 p.

\section{OKLAHOMA GEOLOGICAL SURVEY}

\section{Bulletins}

Bingham, R.H., 1979, Water Resources [of Noble County, Oklahoma], in Shelton, J.W., 1979, Geology and mineral resources of Noble County, Oklahoma: Oklahoma Geological Survey Bulletin 128, $66 \mathrm{p}$.

Davis, L.V., 1955, Geology and water resources of the Grady and northern Stephens Counties, Oklahoma: Oklahoma Geological Survey Bulletin 73, 184 p.

- 1960, Geology and ground-water resources of southern McCurtain County, Oklahoma: Oklahoma Geological Survey Bulletin 86, 108 p.

Hart, D.L., Jr., 1978, Ground water in Custer County, in Fay, R.O., 1978, Geology and mineral resources (exclusive of petroleum) of Custer County, Oklahoma: Oklahoma Geological Survey Bulletin 114, 88 p.

Marine, I.W., and Schoff, S.L., 1962, Ground-water resources of Beaver County, Oklahoma: Oklahoma Geological Survey Bulletin 97, 74 p.

Mogg, J.L., Schoff, S.L., and Reed, E.W., 1960, Ground water resources of Canadian County, Oklahoma: Oklahoma Geological Survey Bulletin 7, 112 p.

Motts, W.S., 1963, Water resources of Okmulgee County, part 2 of Oklahoma Geological Survey, Geology and water resources of Okmulgee County, Oklahoma: Oklahoma Geological Survey Bulletin 91, p. 5-6, 81-123.

Schoff, S.L., 1939, Geology and ground-water resources of Texas County, Oklahoma: Oklahoma Geological Survey Bulletin 59, 248 p. 
— 1943, Geology and ground-water resources of Cimarron County, Oklahoma, with a section on Mesozoic stratigraphy by J.W. Stovall: Oklahoma Geological Survey Bulletin $64,317 \mathrm{p}$.

Schoff, S.L., Reed, E.W., and Branson, C.C., 1955, Geology and ground-water resources of Ottawa County, Oklahoma: Oklahoma Geological Survey Bulletin 72, 203 p.

Warren, J.H., 1952, Water resources of Tulsa County, in Oakes, M.C., Geology and mineral resources of Tulsa County, Oklahoma: Oklahoma Geological Survey Bulletin 69, p. 140155.

\section{Circulars}

D'Lugosz, J.J., McClaflin, R.G., and Marcher, M.V., 1986, Geohydrology of the VamoosaAda aquifer, east-central Oklahoma: Oklahoma Geological Survey Circular 87, 42 p.

Fairchild, R.W., Hanson, R.L., and Davis, R.E., 1990, Hydrology of the Arbuckle Mountains area, south-central Oklahoma: Oklahoma Geological Survey Circular 91, 112 p., 2 plates, scale 1:100,000.

Hart, D.L., Jr., and Davis, R.E., 1981, Geohydrology of the Antlers aquifer (Cretaceous), southeastern Oklahoma: Oklahoma Geological Survey Circular 81, 33 p.

Havens, J.S., 1983, Reconnaissance of ground water in the vicinity of the Wichita Mountains, southwestern Oklahoma: Oklahoma Geological Survey Circular 85, 13 p.

Morton, R.B., 1986, Effects of brine on the chemical quality of water in parts of Creek, Lincoln, Okfuskee, Payne, Pottawatomie, and Seminole Counties, Oklahoma: Oklahoma Geological Survey Circular 89, 38 p.

Playton, S.J., Davis, R.E., and McClaflin, R.G., 1980, Chemical quality of water in abandoned zinc mines in northeastern Oklahoma and southeastern Kansas: Oklahoma Geological Survey Circular 82, 49 p. [Also released as USGS OFR 78-294.]

Schoff, S.L., and Reed, E.W., 1951a, Ground-water resources of the Arkansas River flood plain near Fort Gibson, Muskogee County, Oklahoma: Oklahoma Geological Survey Circular 28, 55 p.

Tanaka, H.H., and Davis, L.V., 1963, Ground-water resources of the Rush Springs Sandstone in the Caddo County area, Oklahoma: Oklahoma Geological Survey Circular 61, 63 p.

Wood, P.R., and Burton, L.C., 1968, Ground-water resources of Cleveland and Oklahoma Counties, Oklahoma: Oklahoma Geological Survey Circular 71, 75 p. 


\section{Mineral Reports}

Davis, L.V., 1950, Ground water in the Pond Creek basin, Caddo County, Oklahoma: Oklahoma Geological Survey Mineral Report 22, 23 p.

— 1953, Oil possibilities near Idabel, McCurtain County, Oklahoma: Oklahoma Geological Survey Mineral Report 23, 26 p.

Dott, R.H., 1942, Geology of Oklahoma ground-water supplies: Oklahoma Geological Survey Mineral Report 11, $26 \mathrm{p}$.

Jacobsen, C.L., and Reed, E.W., 1949, Ground-water supplies in the Oklahoma City area, Oklahoma: Oklahoma Geological Survey Mineral Report 20, 25 p.

Schoff, S.L., 1948, Ground-water irrigation in the Duke area, Jackson and Greer Counties, Oklahoma: Oklahoma Geological Survey Mineral Report 18, 8 p.

1949, Ground-water in Kingfisher County, Oklahoma: Oklahoma Geological Survey Mineral Report 19, 20 p.

1950, Ground-water in the Cherokee area, Alfalfa County, Oklahoma: Oklahoma Geological Survey Mineral Report 21, 17 p.

\section{Geologic Map}

Schoff, S.L., 1955, Map of ground-water reservoirs in Oklahoma: Oklahoma Geological Survey Geologic Map GM-2, scale 1:750,000,1 sheet.

\section{Educational Publication}

Marcher, M.V., 1972, Major sources of water in Oklahoma, in Johnson, K.S., and others, 1972, Geology and earth resources of Oklahoma, An atlas of maps and cross sections: Oklahoma Geological Survey Educational Publication 1, p. 8.

\section{Hydrologic Atlases}

Bingham, R.H., and Bergman, D.L., 1980, Reconnaissance of the water resources of the Enid quadrangle, north-central Oklahoma: Oklahoma Geological Survey Hydrologic Atlas HA-7, 4 sheets, scale 1:250,000.

Bingham, R.H., and Moore, R.L., 1975, Reconnaissance of the water resources of the Oklahoma City quadrangle, central Oklahoma: Oklahoma Geological Survey Hydrologic Atlas 4, scale 1:250,000, 4 sheets. 
Carr, J.E., and Bergman, D.L., 1976, Reconnaissance of the water resources of the Clinton quadrangle, west-central Oklahoma: Oklahoma Geological Survey Hydrologic Atlas 5, scale $1: 250,000,4$ sheets.

Hart, D.L., Jr., 1974, Reconnaissance of the water resources of the Ardmore and Sherman quadrangles, southern Oklahoma: Oklahoma Geological Survey Hydrologic Atlas 3, scale $1: 250,000,4$ sheets.

Havens, J.S., 1977, Reconnaissance of the water resources of the Lawton quadrangle, southwestern Oklahoma: Oklahoma Geological Survey Hydrologic Atlas 6, scale 1:250,000, 4 sheets.

Marcher, M.V., 1969, Reconnaissance of the water resources of the Fort Smith quadrangle, east-central Oklahoma: Oklahoma Geological Survey Hydrologic Atlas 1, scale $1: 250,000,4$ sheets.

Marcher, M.V., and Bergman, D.L., 1983, Reconnaissance of the water resources of the McAlester and Texarkana quadrangles, southeastern Oklahoma: Oklahoma Geological Survey Hydrologic Atlas 9, scale 1:250,000, 4 sheets.

Marcher, M.V., and Bingham, R.H., 1971, Reconnaissance of the water resources of the Tulsa quadrangle, northeastern Oklahoma: Oklahoma Geological Survey Hydrologic Atlas 2, scale 1:250,000, 4 sheets.

Morton, R.B., 1980, Reconnaissance of the water resources of the Woodward quadrangle, northwest Oklahoma: Oklahoma Geological Survey Hydrologic Atlas 8, scale 1:250,000, 4 sheets.

\section{The Hopper and Geology Notes}

Bingham, R.H., 1969a, Springs in northeastern Oklahoma [abs.]: Oklahoma Geological Survey Oklahoma Geology Notes, v. 29, no.1, p. 19.

- 1969b, Springs in the Ozark Region, northeastern Oklahoma: Oklahoma Geological Survey Oklahoma Geology Notes, v. 29, no. 6, p. 135-145.

Blumer, S.P., and Slack, L.J., 1986, Physical and chemical characteristics of water in coalmine ponds, eastern Oklahoma: Oklahoma Geological Survey Oklahoma Geology Notes, v. 46 , no. 4 , p. $128-134$.

Davis, L.V., 1958a, Ground water in the Arbuckle and Simpson Groups in the Arbuckle Mountains, Oklahoma: Oklahoma Geological Survey Oklahoma Geology Notes, v. 18, no. 10 , p. $152-157$.

1958b, Oklahoma's underground water: Oklahoma Geological Survey Oklahoma Geology Notes, v. 18, no. 12, p. 189-202. 
Dott, R.H., 1948, Ground-water supplies in Oklahoma and their development: Oklahoma Geological Survey, The Hopper, v. 8, part 1, July, p. 63-68, part 2, August, p. 71-74, part 3, September, p. 81-89.

Fairchild, R.W., 1984, Springs in the Arbuckle Mountain area, south-central Oklahoma: Oklahoma Geological Survey Oklahoma Geology Notes, v. 44, no. 1, p. 4-11.

Hart, D.L., Jr., 1961, Fluctuations of water levels in wells: Oklahoma Geological Survey Oklahoma Geology Notes, v. 21, no. 2, p. 41-47.

Hauth, L.D., 1985, An overview of hydrologic-data collection by the U.S. Geological Survey in Oklahoma: Oklahoma Geological Survey Oklahoma Geology Notes, v. 45, no. 4, p. 149-161.

Havens, J.S., 1985, Water-level changes in the Ogallala aquifer, northwestern Oklahoma: Oklahoma Geological Survey Oklahoma Geology Notes, v. 45, no. 5, p. 205-210.

Reed, E.W., 1949, Unusual fluctuations in Rush Springs wells: Oklahoma Geological Survey, The Hopper, v. 9, no. 7, p. 69-70.

- 1950, Increased use of ground water for irrigation in the Duke area, Oklahoma: Oklahoma Geological Survey, The Hopper, v. 10, p. 86-90.

Reed, E.W., and Schoff, S.L., 1947, Ground-water storage increases in Tillman County, Oklahoma: Oklahoma Geological Survey, The Hopper, v. 7, p. 77-80.

Schoff, S.L., 1942, Geology and ground-water resources of Beaver County, Oklahoma: Oklahoma Geological Survey, The Hopper, v. 2, no. 10, p. 94-97.

- 1948, Ground-water at high stage in Oklahoma Panhandle: Oklahoma Geological Survey, The Hopper, v. 8, no. 8, p. 74-76.

- 1950, Deep well irrigation in Oklahoma Panhandle: Oklahoma Geological Survey, The Hopper, v. 10 , no. 8 , p. 76 .

- 1953, Ground-water pumpage and water levels in Oklahoma: Oklahoma Geological Survey, The Hopper, v. 13, no. 9-12, p. 51-57.

- 1956, Laverne formation: Oklahoma Geological Survey Oklahoma Geology Notes, v. 16 , no. 1, p. $3-5$.

Scott, J.C., 1984, Use of minicomputers in water-resources investigations: Oklahoma Geological Survey Oklahoma Geology Notes, v. 44, no. 6, p. 188-89.

Tanaka, H.H., 1958, Changes in ground-water levels in Oklahoma during 1957: Oklahoma Geological Survey Oklahoma Geology Notes, v. 18, no. 3, p. 57. 
U.S. Geological Survey, 1974, Summary of October 1973 rainstorm, Enid and vicinity, northcentral Oklahoma: Oklahoma Geological Survey Oklahoma Geology Notes, v. 34, no. 6, p. 209-212.

Ward, P.E., 1961a, Salt springs in Oklahoma: Oklahoma Geological Survey Oklahoma Geology Notes, v. 21, no. 3, p. 81-84.

- 1961b, Shallow halite deposits in northern Woodward and southern Woods Counties, Oklahoma: Oklahoma Geological Survey Oklahoma Geology Notes, v. 21, no. 10, p. 275-277.

\section{Special Publication}

Slack, L.J., and Blumer, S.P., 1987, Physical and chemical characteristics of water in coalmine ponds, eastern Oklahoma: Oklahoma Geological Survey Special Publication 87-2, $116 \mathrm{p}$.

\section{PROFESSIONAL SOCIETIES' ABSTRACTS AND JOURNAL ARTICLES}

Christenson, S.C., 1982, Numerical simulation of the alluvium and terrace aquifer along the North Canadian River from Canton Lake to Lake Overholser, central Oklahoma [abs.]: in Geological Society of America, Annual Meeting, South-central section, Norman, Oklahoma, March 29-30, 1982, p. 107.

Christenson, S.C., and Adams, G.P., 1987, Geohydrology of the freshwater/brine transition zone that surrounds the Ozark Plateaus, Oklahoma, Kansas, Missouri, and Arkansas [abs.]: in Abstracts, Oklahoma Water Resources Conference, 1987, Stillwater, Oklahoma, September 29-30,1987, p. 6, it and in Geological Society of America Annual Meeting, South-central section, Lawrence, Kansas, March 14-15, 1988, p. 114. it and in American Water Resources Assoc., 24th Annual Conference, Milwaukee, Wisconsin, November 6-8, 1988, p. 48.

Clark, W.E., 1956, Forecasting the dry-weather flow of Pond Creek, Oklahoma-A progress report: American Geophysical Union Transactions, v. 37, no. 4, p. 442-450.

Davis, R.E., and Christenson, S.C., 1979, Methods for digital-model evaluation of alluvial deposits of the North Canadian River, northwest Oklahoma [abs.]: in Geological Society of America Annual Meeting, South-central Section, Mountain View, Arkansas, April 910, 1979, p. 146 .

Dover, T.B., Horton, John, and Leonard, A.R., 1957, A look at the water resources of Oklahoma: Oklahoma City Geological Society Shale Shaker, v. 7, no. 10, p. 18-22, 24-32. 
Fairchild, R.W., and Christenson, S.C., 1982, Potential contamination of the Roubidoux aquifer by water from abandoned zinc mines, northeastern Oklahoma [abs.]: Geological Society of America Abstracts with Programs, v. 13, no. 3.

Fairchild, R.W., and Davis, R.E., 1978, Structural control of ground-water flow in the Arbuckle Mountain area, south-central Oklahoma [abs.]: Geological Society of America Abstracts with Programs, v. 10, no. 1, p. 5.

Fairchild, R.W., Davis, R.E., and Hanson, R.L., 1979, Aquifer characteristics of the Arbuckle aquifer, south-central Oklahoma [abs.]: in Geological Society of America, SouthCentral Section, Mountain View, Ark., 1979: Proceedings, Geological Society of America, South-Central Section, v. 11, no. 2, p. 147.

Frye, J.C., and Schoff, S.L., 1942, Deep-seated solution in the Meade basin and vicinity, Kansas and Oklahoma: American Geophysical Union Transactions, v. 24, pt. 1, p. 3539.

Hanson, R.L., 1988, Use of base-flow data to manage water use during a drought: in Marvin Whetstone and R. John Burt, editors, Proceedings of the symposium on Water-use data for water resources management, American Water Resources Association, 1988: Tucson, Arizona, p. 487-498.

Hart, D.L., Jr., and Davis, R.E., 1979, Geohydrology of the Antlers aquifer, southeastern Oklahoma [abs.]: in Geological Society of America, South-Central Section, Mountain View, Ark., 1979: Proceedings, Geological Society of America, South-Central Section, v. 11 , no. 2 , p. 148 .

Havens, J.S., 1982, Generalized altitude and configuration of the base of the High Plains aquifer, northwestern Oklahoma [abs.]: in Geological Society of America, Annual Meeting, South-central section, Norman, Oklahoma, March 29-30, 1982, p. 113.

Irwin, J.H., 1971, Ground-water investigations in Oklahoma, in Rose, W.D., ed., Environmental aspects of geology and engineering in Oklahoma, Annals of the Oklahoma Academy of Science Publication no. 2: Oklahoma Geological Survey, p. 58.

— 1977, Water resources of Oklahoma, in Morris, J.W., ed., Geography of Oklahoma: Oklahoma City, Oklahoma Historical Society, p. 25-39.

Irwin, J.H., and Morton, R.B., 1970, Hydrogeologic information on the Ogallala Formation in the Oklahoma Panhandle and adjoining areas as related to underground waste disposal [abs.]: in Symposium on the Ogallala Aquifer, Lubbock, Tex., 1970: Texas Technological University, p. 30. 
Johnson, K.S., Runkle, D.L., and Becker, M.F., 1990, Hydrogeology of the Rush SpringsMarlow aquifer in the Anadarko Basin, west-central Oklahoma, U.S.A.: Proceedings of the International Association of Hydrologists, Conference on Groundwater in Large Sedimentary Basins, Perth, Western Australia, July 9-10, 1990.

Leonard, A.R., 1960?, Ground water studies in Oklahoma: Midwestern States Flood Control and Water Resources Conference, 14th, Oklahoma City, 1959, 4 p. [Follows p. 52]

1961?, Problems in protecting and developing underground waters in Oklahoma, in Industrial Wastes Conference, 11th, Oklahoma City , 1961?, Proceedings, part 1: Oklahoma City, Oklahoma Water, Sewage, and Industrial Wastes Association, p. 51-55.

Moench, A.F., Sauer, V.B., and Jennings, M.E., 1974, Modification of routed streamflow by channel loss and base flow: Water Resources Research, v. 10, p. 963-968.

Mosier, E.L., Breit, G.N., Schlottmann, J.L., and Papp, C.S.E., 1990, Processes responsible for large concentrations of arsenic, chromium, selenium, uranium, and vanadium in water from the Central Oklahoma aquifer: Geological Society of America Annual Meeting, Program with abstracts, Dallas, Texas, October 29-November 1, 1990, v. 22, no. 7 , p. A61.

Muller, A.B., Parkhurst, D.L., and Tasker, P.W., 1986, Use of the PHREEQE code in modelling environmental geochemical problems encountered in performance assessment modelling, in U.S. Department of Energy, 1985, Symposium on ground-water flow and transport modelling for performance assessment of deep geologic disposal of radioactive waste-A critical evaluation of the state of the art: Albuquerque, N.Mex.

Playton, S.J., Davis, R.E., and McClaflin, R.G., 1978, Water quality in abandoned zinc mines in the Picher field, Tri-State mining district [abs.]: in Geological Society of America Abstracts with Programs, v. 10, no. 1, p. 24.

Rea, A.H., and Scott, J.C., 1990, A computer program to determine map coordinates from public land-survey coordinates [abs.]: in Balthrop, B.H, and Baker, E.G., 1990, U.S. Geological Survey national computer technology meeting: Program and abstracts, May 7-11, 1990: U.S. Geological Survey Open-File Report 90-161, p. 33.

Reed, E.W., and Schoff, S.L., 1952, Aquifers in Ottawa County, Oklahoma: Oklahoma Academy of Science Proceedings, v. 33, p. 194-195.

Runkle, D.L., and Johnson, K.S., 1988, Hydrologic study of a gypsum-dolomite karst aquifer in southwestern Oklahoma and adjacent parts of Texas, U.S.A.: Proceedings of the International Association of Hydrogeologists 21st Congress, Karst hydrogeology and karst environmental protection, October 10-15, 1988, Guilin City, Peoples Republic of China, v. 21, part 1, p. 400-405. 
Sauer, V.B., 1973, Unit response method of open-channel flow routing: American Society of Civil Engineers Proceedings, Journal of the Hydraulics Division, v. 99, p. 179-193.

Schoff, S.L., 1940, Ground Water in the Oklahoma Panhandle: Economic Geology, v. 35, no. 4 , p. $534-545$.

- 1948, Ground-water supplies and uses in Oklahoma, in Oklahoma Conservation Conferences, 3d, 1948, Report of Proceedings: Stillwater, Okla., Oklahoma Research Foundation, Oklahoma Agricultural and Mechanical College, p. 24-36.

— 1955, Triassic rocks on Goff Creek, Texas County, Oklahoma: Oklahoma Academy of Science, v. XXXIV, p. 149-152.

— 1956, Pliocene and Pleistocene fossils from Beaver County, Oklahoma: Oklahoma Academy Science Proceedings, v. 35, p. 94.

Schoff, S.L., and Reed, E.W., 1951, Ground water in alluvial deposits in Oklahoma: Economic Geology, v. 46, no. 1, p. 76-83.

Smith, O.M., 1942, The chemical analysis of the waters of Oklahoma, with contributions by R.H. Dott and E.C. Warkentin: Oklahoma Agricultural and Mechanical College, Engineering Experiment Station Publication 52, 474 p.

\section{OTHER MISCELLANEOUS REPORTS}

Gould, C.N., and Schoff, S.L., 1939, Geological report on water conditions at Platt National Park, Oklahoma: National Park Service Report 249, 38 p., 3 plates. (Also cataloged as U.S. Geological Survey Open-File Report 39-14)

Irwin, J.H., 1971, The Glorieta Sandstone and the Ogallala Formation as related to underground disposal in the High Plains: Tulsa, Arkansas-White-Red River Basins Interagency Committee, January 1971, Minutes, appendix X, p. 2-15.

Oklahoma Water Resources Board, 1975, Salt water detection in the Cimarron terrace, Oklahoma: U.S. Environmental Protection Agency Ecological Research Series EPA660/3-74-033, $166 \mathrm{p}$. 


\title{
SOURCES OF U.S. GEOLOGICAL SURVEY PUBLICATIONS AND BOOKS
}

\section{BOOKS, MAPS, AND PERIODICALS}

Since 1879, the U.S. Geological Survey has served the public, and Federal, State, and local governments by collecting, analyzing, and publishing detailed information about the Nation's mineral, land, and water resources. This information is in a variety of map, book, and other formats, and is available from several sources within the Geological Survey.

\section{Text Products-Books and Open-File Reports}

To order USGS book publications, catalogs, and pamphlets, and for information on the availability of microfiche or paper duplicate copies of selected open-file reports, write:

Books and Open-File Reports Section

U.S. Geological Survey

Federal Center, Box 25425

Denver, CO 80225

(303)236-7476

MAPS

To order geologic, hydrologic, topographic, and land-use and land-cover maps published by the USGS, write:

USGS Map Sales

U.S. Geological Survey

Federal Center, Box 25286

Denver, CO 80225

(303) 236-7477

New Publications

To get on the mailing list for the free monthly catalog "New Publications of the Geological Survey" write:

\author{
U.S. Geological Survey \\ 582 National Center \\ Reston, VA 22092
}




\section{INFORMATION}

\section{Public Inquiries Office}

USGS Public Inquiries Offices provide general information about the Geological Survey's programs and its publications, and they sell, over the counter, maps of local areas and books of local and general interest. The nearest Public Inquiries Office to the Oklahoma City area is:

Public Inquiries Office

U.S. Geological Survey

169 Federal Building

1961 Stout Street

Denver, CO 80294

(303) $844-4169$

\section{Data Information Services:}

The Oklahoma District also manages the following data information services that provide water-resources data in an easy-to-use and readily available from:

NAWDEX (NAtional Water Data EXchange) provides information on the location and types of data available on water and related subjects. (District contact for this information is Lionel D. Mize.)

Watstore (WATer Data STOrage and REtrieval System) provides the following types of information:

1. Well depth, depth to water, well yield, name of aquifer, and well-construction data for nearly 20,000 ground-water wells in Oklahoma.

2. Current discharge and quality-of-water data from about 150 streams, lakes, and springs in Oklahoma.

3. Current peak-flow data from about 40 partial-record stations in Oklahoma.

(District contacts for this information are Joanne K. Kurklin and Jayne May.)

General information on OKlahoma water resources and publications:

For general information on water resources and availability of publications dealing with Oklahoma, contact:

Kathy D. Peter, District Chief

U.S. Geological Survey, Water Resources Division

Bldg. 7, 202 NW 66th Street

Oklahoma City, OK 73116

(405) 231-4256 
Table 1.-Ground-water sites included in the mass measurement network [Aquifer codes are listed inside back cover.]

\begin{tabular}{|c|c|c|c|c|c|c|c|}
\hline Site-ID & Local well number & County & $\begin{array}{l}\text { Aquifer } \\
\text { code }\end{array}$ & $\begin{array}{c}\text { Diameter } \\
\text { of } \\
\text { casing } \\
\text { (in.) }\end{array}$ & $\begin{array}{c}\text { Depth } \\
\text { of well } \\
(\mathrm{ft})\end{array}$ & $\begin{array}{c}\text { OWRB } \\
\text { identifier }\end{array}$ & $\begin{array}{c}\text { Period } \\
\text { of } \\
\text { record }\end{array}$ \\
\hline 355914094340001 & $17 \mathrm{~N}-26 \mathrm{E}-05 \mathrm{BAA} 1$ & Adair & $331 \mathrm{BOON}$ & - & - & 9001 & $1979-$ \\
\hline 355742094331201 & $17 \mathrm{~N}-26 \mathrm{~W}-09 \mathrm{CCA} 1$ & Adair & 331PTKN & - & 140 & 9000 & $1979-$ \\
\hline 360000094353501 & $18 \mathrm{~N}-25 \mathrm{E}-36$ ADD 1 & Adair & $331 \mathrm{BOON}$ & - & 42.0 & 9002 & $1977-$ \\
\hline 360006094340001 & $18 \mathrm{~N}-26 \mathrm{E}-32 \mathrm{BAA} 1$ & Adair & $331 \mathrm{BOON}$ & - & 100 & 9003 & $1982-$ \\
\hline 362953098245401 & $23 \mathrm{~N}-11 \mathrm{~W}-06$ BBB 1 & Alfalfa & 110CMTA & 6 & 25.8 & 9004 & $1950-$ \\
\hline 363823098233701 & $25 \mathrm{~N}-11 \mathrm{~W}-16 \mathrm{CCD} 1$ & Alfalfa & 110CMTA & - & 86.0 & 9005 & $1975-$ \\
\hline 365028098104001 & $27 \mathrm{~N}-09 \mathrm{~W}-09$ BBA 1 & Alfalfa & 112TRRCH & - & 31.0 & 9008 & $1975-$ \\
\hline 364909098210301 & $27 N-11 W-14$ DBB 1 & Alfalfa & 112TRRCH & - & 37.0 & 9007 & $1975-$ \\
\hline 364837098205501 & $27 \mathrm{~N}-11 \mathrm{~W}-23$ ABD 1 & Alfalfa & 112TRRCH & - & 41.0 & 9006 & $1975-$ \\
\hline 365916098125001 & $29 \mathrm{~N}-09 \mathrm{~W}-18 \mathrm{CDD} 1$ & Alfalfa & $112 \mathrm{TRRCH}$ & - & 35 & 9009 & $1975^{-}$ \\
\hline 341938096090001 & 03S- $11 \mathrm{E}-04$ ACA 1 & Atoka & 218ALRS & - & 73.0 & 9010 & $1976-$ \\
\hline 363035100490201 & $01 \mathrm{~N}-21 \mathrm{E}-32$ ABC 1 & Beaver & 121OGLL & - & 430 & 9015 & $1964-$ \\
\hline 363411100384701 & $01 \mathrm{~N}-22 \mathrm{E}-12$ BCB 1 & Beaver & 121OGLL & - & - & 9024 & $1967-$ \\
\hline 363136100430001 & $01 \mathrm{~N}-22 \mathrm{E}-29 \mathrm{BBD} 1$ & Beaver & 121OGLL & 6.6 & 245 & 9017 & $1980-$ \\
\hline 363011100410601 & $01 \mathrm{~N}-22 \mathrm{E}-33$ DDD 1 & Beaver & 121OGLL & 2 & 365 & 9012 & $1970-$ \\
\hline 363006100404201 & $01 \mathrm{~N}-22 \mathrm{E}-34 \mathrm{CDC} 1$ & Beaver & 121OGLL & 16 & 343 & 9011 & $1967-$ \\
\hline 363342100360801 & $01 \mathrm{~N}-23 \mathrm{E}-08 \mathrm{DCB} 1$ & Beaver & 121OGLL & 2 & 512 & 9022 & $1970-$ \\
\hline 363233100324001 & $01 \mathrm{~N}-23 \mathrm{E}-23 \mathrm{AAB} 1$ & Beaver & 121OGLL & - & 176 & 9019 & $1968-$ \\
\hline 363138100332701 & $01 \mathrm{~N}-23 \mathrm{E}-26$ BBB 1 & Beaver & 121OGLL & 6 & 440 & 9018 & $1967-$ \\
\hline 363136100363701 & $01 \mathrm{~N}-23 \mathrm{E}-29 \mathrm{BBC} 1$ & Beaver & $1210 G L L$ & 16 & 560 & 9016 & $1967-$ \\
\hline 363514100251801 & $01 \mathrm{~N}-24 \mathrm{E}-01$ ABB 1 & Beaver & 121OGLL & 16 & 330 & 107 & $1967-$ \\
\hline 363017100250501 & $01 \mathrm{~N}-24 \mathrm{E}-36 \mathrm{DAC} 1$ & Beaver & 121OGLL & 6.6 & 250 & 9013 & $1980-$ \\
\hline 363424100192501 & $01 \mathrm{~N}-25 \mathrm{E}-01 \mathrm{CCC} 1$ & Beaver & 121OGLL & 5 & 240 & 9025 & $1980-$ \\
\hline 363356100241801 & $01 \mathrm{~N}-25 \mathrm{E}-07 \mathrm{CAA} 1$ & Beaver & 121OGLL & 4 & 111 & 9023 & $1968-$ \\
\hline 363319100142401 & $01 \mathrm{~N}-26 \mathrm{E}-15$ ABD 2 & Beaver & 121 OGLL & 16 & 120 & 9021 & $1980-$ \\
\hline 363028100124101 & $01 \mathrm{~N}-26 \mathrm{E}-36 \mathrm{BDC} 1$ & Beaver & 121OGLL & - & - & 9014 & $1967-$ \\
\hline 363451100111801 & $01 \mathrm{~N}-27 \mathrm{E}-06$ ACB 1 & Beaver & 121OGLL & 2 & 122 & 9026 & $1970-$ \\
\hline 363235100093301 & $01 \mathrm{~N}-27 \mathrm{E}-21 \mathrm{BBA} 1$ & Beaver & 121OGLL & - & 186 & 9020 & $1967-$ \\
\hline 363600100144701 & $01 \mathrm{~N}-27 \mathrm{E}-35$ DAC 1 & Beaver & 121OGLL & - & 168 & 9031 & $1967-$ \\
\hline 363503100010001 & $01 \mathrm{~N}-28 \mathrm{E}-02 \mathrm{BCA} 1$ & Beaver & 121OGLL & 16 & 256 & 9027 & $1968-$ \\
\hline 364015100505401 & $02 \mathrm{~N}-20 \mathrm{E}-01$ AAA 1 & Beaver & 121OGLL & 6 & 81.0 & 9043 & $1968-$ \\
\hline 363847100460601 & $02 \mathrm{~N}-21 \mathrm{E}-11 \mathrm{CDD} 1$ & Beaver & 121OGLL & 16 & 301 & 9039 & $1967-$ \\
\hline 363759100391901 & $02 \mathrm{~N}-22 \mathrm{E}-14$ DCC 1 & Beaver & 121OGLL & - & 379 & 9036 & $1967-$ \\
\hline 363816100321901 & $02 \mathrm{~N}-23 \mathrm{E}-13 \mathrm{BCC} 1$ & Beaver & 121OGLL & 14 & 53.0 & 9037 & $1967-$ \\
\hline 364018100283001 & $02 \mathrm{~N}-24 \mathrm{E}-04 \mathrm{ABD} 1$ & Beaver & 121OGLL & 5 & 40.0 & 9044 & $1980-$ \\
\hline 363853100311001 & $02 \mathrm{~N}-24 \mathrm{E}-07 \mathrm{CCD} 1$ & Beaver & 121OGLL & 6 & 95 & 9040 & $1946-$ \\
\hline 364036100240301 & $02 \mathrm{~N}-25 \mathrm{E}-06$ AAB 1 & Beaver & 121OGLL & 5 & 234 & 9047 & $1980-$ \\
\hline 363925100202501 & $02 \mathrm{~N}-25 \mathrm{E}-11 \mathrm{BBD} 1$ & Beaver & 121OGLL & 5 & 160 & 9041 & $1980-$ \\
\hline 363740100235001 & $02 \mathrm{~N}-25 \mathrm{E}-19$ ADD 2 & Beaver & 121OGLL & 16 & 205 & 9035 & $1967-$ \\
\hline 363720100185301 & $02 \mathrm{~N}-25 \mathrm{E}-24 \mathrm{DBB} 1$ & Beaver & 121OGLL & 5 & 245 & 9034 & $1980-$ \\
\hline
\end{tabular}


Table 1.-Ground-water sites included in the mass measurement network-Continued

\begin{tabular}{|c|c|c|c|c|c|c|c|}
\hline Site-ID & Local well number & County & $\begin{array}{c}\text { Aquifer } \\
\text { code }\end{array}$ & $\begin{array}{l}\text { Diameter } \\
\text { of } \\
\text { casing } \\
\text { (in.) } \\
\end{array}$ & $\begin{array}{c}\text { Depth } \\
\text { of well } \\
\text { (ft) }\end{array}$ & $\begin{array}{c}\text { OWRB } \\
\text { identifier }\end{array}$ & $\begin{array}{c}\text { Period } \\
\text { of } \\
\text { record }\end{array}$ \\
\hline 363558100221001 & $02 \mathrm{~N}-25 \mathrm{E}-33$ ACA 1 & Beaver & 121OGLL & 2 & 353 & 9030 & $1971-$ \\
\hline 364026100134901 & $02 \mathrm{~N}-26 \mathrm{E}-02$ BBA 1 & Beaver & 121OGLL & - & 154 & 9045 & $1967-$ \\
\hline 364008100063901 & $02 \mathrm{~N}-27 \mathrm{E}-02$ AAD 2 & Beaver & $110 \mathrm{ALVM}$ & 16 & 82.0 & 9042 & $1967-$ \\
\hline 363831100082301 & $02 \mathrm{~N}-27 \mathrm{E}-15$ BCB 1 & Beaver & 110ALVM & 18 & 70.0 & 9038 & $1967-$ \\
\hline 363705100093101 & $02 \mathrm{~N}-27 \mathrm{E}-21 \mathrm{CDB} 2$ & Beaver & 110ALVM & 16 & 87.5 & 9033 & $1968-$ \\
\hline 363613100100601 & $02 \mathrm{~N}-27 \mathrm{E}-29$ DCD 3 & Beaver & 110ALVM & 18 & 57 & 9032 & $1967-$ \\
\hline 363527100105501 & $02 \mathrm{~N}-27 \mathrm{E}-31 \mathrm{DDA} 1$ & Beaver & 110ALVM & - & 87.0 & 338 & $1967-$ \\
\hline 364228100341701 & $03 \mathrm{~N}-23 \mathrm{E}-22 \mathrm{CAC} 1$ & Beaver & 121OGLL & 5 & 180 & 9051 & $1980-$ \\
\hline 364110100374501 & $03 \mathrm{~N}-23 \mathrm{E}-31$ BBC 1 & Beaver & 121OGLL & 5 & 280 & 9048 & $1980-$ \\
\hline 364348100305101 & $03 \mathrm{~N}-24 \mathrm{E}-18$ BAA 1 & Beaver & 121OGLL & 6 & - & 9052 & $1968-$ \\
\hline 364036100202601 & $03 \mathrm{~N}-25 \mathrm{E}-35 \mathrm{CCA} 1$ & Beaver & 121OGLL & 6 & 220 & 9046 & $1980-$ \\
\hline 364500100181201 & $03 \mathrm{~N}-26 \mathrm{E}-06 \mathrm{CCC} 1$ & Beaver & 121OGLL & 6 & 96.0 & 9054 & $1968-$ \\
\hline 364445100142401 & $03 \mathrm{~N}-26 \mathrm{E}-10$ AAB 1 & Beaver & 121OGLL & 6 & 44.0 & 9053 & $1967-$ \\
\hline 364226100085901 & $03 \mathrm{~N}-27 \mathrm{E}-21 \mathrm{DBD}$ & Beaver & 121OGLL & 5 & 138 & 9050 & 1980- \\
\hline 364206100030901 & $03 \mathrm{~N}-28 \mathrm{E}-28 \mathrm{BAB} 1$ & Beaver & 112TRRCH & 5 & 59.0 & 9049 & $1978-$ \\
\hline 364728100533101 & $04 \mathrm{~N}-20 \mathrm{E}-22 \mathrm{CAD} 1$ & Beaver & 121OGLL & 16 & 330 & 9058 & $1967-$ \\
\hline 364901100381901 & $04 \mathrm{~N}-22 \mathrm{E}-13 \mathrm{ABB} 1$ & Beaver & $110 \mathrm{ALVM}$ & 16 & 60.0 & 9062 & $1967-$ \\
\hline 364807100400601 & $04 \mathrm{~N}-22 \mathrm{E}-22$ AAD 1 & Beaver & 121OGLL & 5 & 300 & 9061 & $1980-$ \\
\hline 364734100254501 & $04 \mathrm{~N}-24 \mathrm{E}-24 \mathrm{CCC} 1$ & Beaver & 110ALVM & 4 & 34.0 & 9059 & $1967-$ \\
\hline 364719100223501 & $04 \mathrm{~N}-25 \mathrm{E}-28 \mathrm{BBB} 1$ & Beaver & 121OGLL & 6 & 63.0 & 9057 & $1968-$ \\
\hline 364626100242601 & $04 \mathrm{~N}-25 \mathrm{E}-31$ ABC 1 & Beaver & 121OGLL & 5 & 132 & 9056 & $1968-$ \\
\hline 365014100070901 & $04 \mathrm{~N}-27 \mathrm{E}-02 \mathrm{CDC} 1$ & Beaver & 121OGLL & 5 & 140 & 9063 & $1980-$ \\
\hline 364551100064401 & $04 \mathrm{~N}-27 \mathrm{E}-35$ DDB 1 & Beaver & 121OGLL & 5 & 40.0 & 9055 & $1980-$ \\
\hline 365045100002501 & $04 \mathrm{~N}-28 \mathrm{E}-02$ AAC 1 & Beaver & 121OGLL & 5 & 160 & 9065 & 1981- \\
\hline 365038100043301 & $04 \mathrm{~N}-28 \mathrm{E}-06$ ADA 1 & Beaver & 121OGLL & - & 77.0 & 9064 & $1967-$ \\
\hline 365507100515301 & $05 \mathrm{~N}-20 \mathrm{E}-02$ DCC 1 & Beaver & 121OGLL & 16 & 575 & 9079 & $1968-$ \\
\hline 365141100542101 & $05 \mathrm{~N}-20 \mathrm{E}-28 \mathrm{CCC} 1$ & Beaver & 121OGLL & 16 & 503 & 572 & $1968-$ \\
\hline 365450100475501 & $05 \mathrm{~N}-21 \mathrm{E}-09 \mathrm{BBC} 1$ & Beaver & 121OGLL & 2 & 438 & 9078 & $1970-$ \\
\hline 365419100472001 & $05 \mathrm{~N}-21 \mathrm{E}-09$ DCD 1 & Beaver & 121OGLL & 16 & 525 & 9077 & $1967-$ \\
\hline 365418100465001 & $05 \mathrm{~N}-21 \mathrm{E}-10 \mathrm{CAA} 1$ & Beaver & 121OGLL & 16 & 560 & 9076 & $1967-$ \\
\hline 365343100483001 & $05 \mathrm{~N}-21 \mathrm{E}-17 \mathrm{DBB} 1$ & Beav & 121OGLL & 16 & 458 & 613 & $1967-$ \\
\hline 365206100422901 & $05 \mathrm{~N}-22 \mathrm{E}-29 \mathrm{CBA} 1$ & Beaver & 121OGLL & - & 180 & 9069 & $1967-$ \\
\hline 365316100335201 & $05 \mathrm{~N}-23 \mathrm{E}-22 \mathrm{BBB} 1$ & Beaver & 121OGLL & 6 & 135 & 9071 & $1967-$ \\
\hline 365323100303101 & $05 \mathrm{~N}-24 \mathrm{E}-19$ BBD 1 & Beaver & 121OGLL & - & 102 & 9073 & $1980-$ \\
\hline 365553100214301 & 05N-25E-04 BAC 1 & Beaver & 1210GLL & - & 200 & 9081 & $1967-$ \\
\hline 365138100203201 & 05N-25E-34 BAD 1 & Beaver & 121OGLL & 5 & 191 & 9066 & $1980-$ \\
\hline 365331100135801 & 05N-26E-15 CDD 1 & Beaver & 121OGLL & 2 & 465 & 9074 & $1970-$ \\
\hline 365524100063401 & 05N-27E-02 CDB 1 & Beaver & 121OGLL & 5 & 180 & 9080 & $1980-$ \\
\hline 365321100013201 & $05 \mathrm{~N}-28 \mathrm{E}-22 \mathrm{ABA} 1$ & Beaver & 121OGLL & -- & 250 & 9072 & $1968-$ \\
\hline 365214100021201 & $05 \mathrm{~N}-28 \mathrm{E}-27 \mathrm{BCD} 1$ & Beaver & 1210GLL & 16 & 91.0 & 9070 & $1967-$ \\
\hline
\end{tabular}


Table 1.-Ground-water sites included in the mass measurement network-Continued

\begin{tabular}{|c|c|c|c|c|c|c|c|}
\hline Site-ID & Local well number & County & $\begin{array}{l}\text { Aquifer } \\
\text { code }\end{array}$ & $\begin{array}{c}\text { Diameter } \\
\text { of } \\
\text { casing } \\
\text { (in.) }\end{array}$ & $\begin{array}{c}\text { Depth } \\
\text { of well } \\
\text { (ft) }\end{array}$ & $\begin{array}{c}\text { OWRB } \\
\text { identifier }\end{array}$ & $\begin{array}{l}\text { Period } \\
\text { of } \\
\text { record }\end{array}$ \\
\hline 365600100515101 & $06 N-20 E-35$ DCC 1 & Beaver & 121OGLL & 16 & 560 & 710 & $1967-$ \\
\hline 365748100371901 & $06 \mathrm{~N}-22 \mathrm{E}-24 \mathrm{DDD} 1$ & Beaver & 121OGLL & 5 & 128 & 9085 & $1967-$ \\
\hline 365632100423701 & $06 N-22 E-32$ CBB 1 & Beaver & 121OGLL & 16 & 500 & 9083 & $1980-$ \\
\hline 365701100272001 & $06 \mathrm{~N}-24 \mathrm{E}-27 \mathrm{CCC} 1$ & Beaver & 121OGLL & 5 & 192 & 9084 & $1967-$ \\
\hline 365947100241101 & $06 \mathrm{~N}-25 \mathrm{E}-07 \mathrm{CCB} 1$ & Beaver & 121OGLL & 5 & 88.0 & 9087 & $1980-$ \\
\hline 365757100221001 & $06 \mathrm{~N}-25 \mathrm{E}-20$ DDD 1 & Beaver & 110ALVM & - & 164 & 9086 & $1980-$ \\
\hline 350727099274901 & $08 \mathrm{~N}-21 \mathrm{~W}-31 \mathrm{CBB} 1$ & Beckham & 112TRRCH & - & 76.0 & 9088 & $1980-$ \\
\hline 351215099292401 & $08 \mathrm{~N}-22 \mathrm{~W}-02$ ABB 1 & Beckham & 313RSPG & - & 210 & 9094 & $1981-$ \\
\hline 350839099303001 & $08 \mathrm{~N}-22 \mathrm{~W}-27 \mathrm{AAD} 1$ & Beckham & - & - & 50.0 & 9089 & $1980-$ \\
\hline 351030099385401 & $08 \mathrm{~N}-23 \mathrm{~W}-17$ AAB 1 & Beckham & 313RSPG & - & 80.0 & 9090 & $1980-$ \\
\hline 351129099415601 & $08 \mathrm{~N}-24 \mathrm{~W}-02 \mathrm{DCD} 1$ & Beckham & - & - & - & 9093 & 1986- \\
\hline 351122099435501 & $08 \mathrm{~N}-24 \mathrm{~W}-09$ AAB 1 & Beckham & 112TRRCH & - & 142 & 9092 & $1980-$ \\
\hline 351119099494101 & $08 \mathrm{~N}-25 \mathrm{~W}-10 \mathrm{BAA} 1$ & Beckham & 313DGCK & 14 & 82.0 & 9091 & $1980-$ \\
\hline 351347099324101 & $09 \mathrm{~N}-22 \mathrm{~W}-29$ AAD 1 & Beckham & 112TRRCH & - & 64.0 & 9103 & $1980-$ \\
\hline 351334099344001 & $09 \mathrm{~N}-22 \mathrm{~W}-30 \mathrm{BCC} 1$ & Beckham & 112TRRCH & - & 67.0 & 9102 & $1980-$ \\
\hline 351301099323301 & $09 \mathrm{~N}-22 \mathrm{~W}-33$ BBB 1 & Beckham & 112TRRCH & - & 74.0 & 9098 & $1980-$ \\
\hline 351518099375901 & $09 \mathrm{~N}-23 \mathrm{~W}-16$ ADD 1 & Beckham & 112TRRCH & - & - & 9115 & $1981-$ \\
\hline 351426099372701 & $09 \mathrm{~N}-23 \mathrm{~W}-22$ BDD 1 & Beckham & 112TRRCH & - & - & 9109 & $1980-$ \\
\hline 351446099362401 & $09 \mathrm{~N}-23 \mathrm{~W}-23$ BAA 1 & Beckham & 112TRRCH & - & 113 & 9111 & $1980-$ \\
\hline 351308099353601 & $09 \mathrm{~N}-23 \mathrm{~W}-25 \mathrm{CCD} 1$ & Beckham & 112TRRCH & - & - & 9100 & $1980-$ \\
\hline 351353099383101 & $09 \mathrm{~N}-23 \mathrm{~W}-28 \mathrm{BAA} 1$ & Beckham & 112TRRCH & - & 80.0 & 9104 & $1980-$ \\
\hline 351222099395801 & $09 \mathrm{~N}-23 \mathrm{~W}-32 \mathrm{CCB} 1$ & Beckham & 112TRRCH & 一 & - & 9096 & $1980-$ \\
\hline 351512099411001 & $09 N-24 W-13$ DAA 1 & Beckham & - & - & 30.0 & 9113 & $1980-$ \\
\hline 351512099472401 & $09 \mathrm{~N}-24 \mathrm{~W}-18 \mathrm{CBB} 1$ & Beckham & 112TRRCH & - & 120 & 9114 & $1980-$ \\
\hline 351413099451601 & $09 \mathrm{~N}-24 \mathrm{~W}-21 \mathrm{CBC} 1$ & Beckham & 112TRRCH & - & 59.0 & 9108 & $1980-$ \\
\hline 351242099420601 & $09 \mathrm{~N}-24 \mathrm{~W}-36 \mathrm{BCC} 1$ & Beckham & 112TRRCH & - & 123 & 9097 & $1980-$ \\
\hline 351637099521001 & $09 \mathrm{~N}-25 \mathrm{~W}-05$ DCC 1 & Beckham & 112TRRCH & - & $\ldots$ & 9120 & 1980 \\
\hline 351557099522601 & $09 \mathrm{~N}-25 \mathrm{~W}-08 \mathrm{CAC} 1$ & Beckham & 112TRRCH & - & 160 & 9117 & $1980-$ \\
\hline 351617099482701 & $09 \mathrm{~N}-25 \mathrm{~W}-12 \mathrm{BCB} 1$ & Beckham & 112TRRCH & - & 130 & 9118 & $1980-$ \\
\hline 351452099494701 & $09 \mathrm{~N}-25 \mathrm{~W}-15$ DDC 1 & Beckham & 112TRRCH & - & 73.0 & 9112 & $1980-$ \\
\hline 351402099533501 & $09 \mathrm{~N}-25 \mathrm{~W}-19 \mathrm{CCC} 1$ & Beckham & 112DUNE & 6 & 36.0 & 9107 & $1980-$ \\
\hline 351353099482701 & $09 \mathrm{~N}-25 \mathrm{~W}-25 \mathrm{BBB} 1$ & Beckham & 112TRRCH & - & 100 & 9105 & $1980-$ \\
\hline 351400099533501 & $09 \mathrm{~N}-25 \mathrm{~W}-31$ BCB 1 & Beckham & 112TRRCH & 6 & 34.8 & 9106 & $1980-$ \\
\hline 351216099483501 & $09 \mathrm{~N}-25 \mathrm{~W}-35$ DDD 1 & Beckham & 112TRRCH & - & 86.0 & 9095 & $1980-$ \\
\hline 351617099590301 & $09 \mathrm{~N}-26 \mathrm{~W}-08 \mathrm{BCB} 1$ & Beckham & 112TRRCH & - & 63.0 & 9119 & $1980-$ \\
\hline 351525099560801 & $09 \mathrm{~N}-26 \mathrm{~W}-15$ ADB 1 & Beckham & 112TRRCH & - & 150 & 9116 & $1980-$ \\
\hline 351433099544101 & $09 \mathrm{~N}-26 \mathrm{~W}-24$ BCA 1 & Beckham & 112TRRCH & - & 219 & 9110 & $1980-$ \\
\hline 351327099595901 & $09 \mathrm{~N}-26 \mathrm{~W}-30 \mathrm{CBA} 1$ & Beckham & 112TRRCH & 一 & 70.0 & 9101 & $1980-$ \\
\hline 351306099515501 & $09 \mathrm{~N}-26 \mathrm{~W}-33$ BBB 1 & Beckham & 112TRRCH & 6 & 32.8 & 9099 & $1980-$ \\
\hline 351755099563201 & $10 \mathrm{~N}-26 \mathrm{~W}-34 \mathrm{BDD} 1$ & Beckham & 112TRRCH & - & - & 9121 & $1980-$ \\
\hline
\end{tabular}


Table 1.-Ground-water sites included in the mass measurement network-Continued

\begin{tabular}{|c|c|c|c|c|c|c|c|}
\hline Site-ID & Local well number & County & $\begin{array}{c}\text { Aquifer } \\
\text { code }\end{array}$ & $\begin{array}{c}\text { Diameter } \\
\text { of } \\
\text { casing } \\
\text { (in.) }\end{array}$ & $\begin{array}{c}\text { Depth } \\
\text { of well } \\
(\mathrm{ft})\end{array}$ & $\begin{array}{c}\text { OWRB } \\
\text { identifier }\end{array}$ & $\begin{array}{l}\text { Period } \\
\text { of } \\
\text { record }\end{array}$ \\
\hline 352426099572801 & $11 \mathrm{~N}-26 \mathrm{~W}-21 \mathrm{DCC} 1$ & Beckham & $1210 G L L$ & - & 90.0 & 9123 & $1980-$ \\
\hline 352328099560001 & $11 \mathrm{~N}-26 \mathrm{~W}-34$ AAA 1 & Beckham & 112TRRCH & - & 32.0 & 9122 & $1980-$ \\
\hline 353616098334601 & $13 \mathrm{~N}-13 \mathrm{~W}-15$ ADA 1 & Blaine & 313RSPG & 6 & 275 & 9204 & $1982-$ \\
\hline 355151098215101 & $16 \mathrm{~N}-11 \mathrm{~W}-15 \mathrm{BCC} 1$ & Blaine & 112TRRCH & - & 76.0 & 9125 & $1981-$ \\
\hline 355045098243101 & $16 \mathrm{~N}-11 \mathrm{~W}-19 \mathrm{DBC} 1$ & Blaine & 112TRRCH & - & 50.0 & 5131 & $1976-$ \\
\hline 355724098283501 & 17N-12W-09 DDD 1 & Blaine & 112TRRCH & - & 80.0 & 9127 & $1977-$ \\
\hline 360927098354701 & $19 \mathrm{~N}-13 \mathrm{~W}-04 \mathrm{BBA} 1$ & Blaine & 112TRRCH & - & 48.0 & 9130 & $1976-$ \\
\hline 360631098331501 & $19 \mathrm{~N}-13 \mathrm{~W}-23$ ACC 1 & Blaine & 112TRRCH & - & 72.0 & 9129 & $1976-$ \\
\hline 360600098324701 & $19 \mathrm{~N}-13 \mathrm{~W}-25 \mathrm{BBB} 1$ & Blaine & 112TRRCH & 12 & 54.0 & 9128 & $1978-$ \\
\hline 340135096013601 & 06S- $12 \mathrm{E}-23 \mathrm{BBB} 1$ & Bryan & - & - & - & 9131 & $1977-$ \\
\hline 350902098235501 & $08 \mathrm{~N}-11 \mathrm{~W}-19 \mathrm{CAC}$ & Caddo & 313RSPG & 14 & 287 & 9133 & $1955-$ \\
\hline 350832098282101 & $08 \mathrm{~N}-12 \mathrm{~W}-28 \mathrm{BDB} 1$ & Caddo & 313RSPG & 16 & 245 & 9132 & $1955-$ \\
\hline 350930098352501 & $08 \mathrm{~N}-13 \mathrm{~W}-20$ ABA 1 & Caddo & 313RSPG & 16 & 300 & 9134 & $1974-$ \\
\hline 351459098260201 & $09 \mathrm{~N}-12 \mathrm{~W}-14 \mathrm{DDB} 1$ & Caddo & 313RSPG & - & 294 & 9138 & 1974- \\
\hline 351439098263401 & $09 \mathrm{~N}-12 \mathrm{~W}-23 \mathrm{BAC} 1$ & Caddo & 313RSPG & - & 235 & 9137 & $1974-$ \\
\hline 351623098312001 & $09 \mathrm{~N}-13 \mathrm{~W}-12$ AAC 1 & Caddo & 313RSPG & - & 285 & 3899 & $1974-$ \\
\hline 351302098351501 & $09 \mathrm{~N}-13 \mathrm{~W}-33 \mathrm{BBB} 1$ & Caddo & 313RSPG & - & - & 9135 & 1974- \\
\hline 352225098274001 & $10 \mathrm{~N}-12 \mathrm{~W}-03 \mathrm{BBD} 1$ & Caddo & 313RSPG & 16 & 335 & 9151 & $1974-$ \\
\hline 352229098300901 & $10 \mathrm{~N}-12 \mathrm{~W}-06 \mathrm{AAD} 1$ & Caddo & 313RSPG & - & 306 & 9152 & 1974- \\
\hline 352107098273801 & $10 \mathrm{~N}-12 \mathrm{~W}-10 \mathrm{CCA} 1$ & Caddo & 313RSPG & 21 & 340 & 4017 & 1974- \\
\hline 352015098253001 & $10 \mathrm{~N}-12 \mathrm{~W}-13 \mathrm{CCA} 1$ & Caddo & 313RSPG & 16 & 355 & 9147 & $1956-$ \\
\hline 352017098263301 & $10 \mathrm{~N}-12 \mathrm{~W}-14 \mathrm{CBD} 1$ & Caddo & 313RSPG & 18 & 320 & 9148 & $1974-$ \\
\hline 352046098285901 & $10 \mathrm{~N}-12 \mathrm{~W}-17$ AAD 1 & Caddo & 313RSPG & 14 & 328 & 4039 & $1977-$ \\
\hline 351923098291301 & $10 \mathrm{~N}-12 \mathrm{~W}-20 \mathrm{DAC} 1$ & Caddo & 313RSPG & 16 & 340 & 9144 & $1974-$ \\
\hline 351950098263601 & $10 \mathrm{~N}-12 \mathrm{~W}-23$ BBD 1 & Caddo & 313RSPG & 16 & 288 & 9145 & $1955-$ \\
\hline 351730098300301 & $10 \mathrm{~N}-12 \mathrm{~W}-31$ DDB 2 & Caddo & 313RSPG & 16 & 307 & 9140 & $1982-$ \\
\hline 351805098281201 & $10 \mathrm{~N}-12 \mathrm{~W}-33$ ABD 1 & Caddo & 313RSPG & - & 290 & 4093 & $1975^{-}$ \\
\hline 351755098265801 & $10 \mathrm{~N}-12 \mathrm{~W}-34$ ADD 1 & Caddo & 313RSPG & - & 268 & 9142 & $1973-$ \\
\hline 351748098264201 & $10 \mathrm{~N}-12 \mathrm{~W}-35 \mathrm{CBA} 1$ & Caddo & 313RSPG & - & 230 & 9141 & 1974- \\
\hline 351952098332801 & $10 \mathrm{~N}-13 \mathrm{~W}-22$ AAC 1 & Caddo & 313RSPG & 16 & 328 & 9146 & 1975 \\
\hline 352715098234901 & $11 \mathrm{~N}-11 \mathrm{~W}-06 \mathrm{DAC} 1$ & Caddo & 313RSPG & 14 & 285 & 9158 & $1983-$ \\
\hline 352514098223501 & $11 \mathrm{~N}-11 \mathrm{~W}-21 \mathrm{BBB} 1$ & Caddo & 313RSPG & 18 & 120 & 9075 & $1988-$ \\
\hline 352316098284101 & $11 \mathrm{~N}-12 \mathrm{~W}-04 \mathrm{CAC} 1$ & Caddo & 313RSPG & 16 & 309 & 9154 & $1956-$ \\
\hline 352515098263001 & $11 \mathrm{~N}-12 \mathrm{~W}-14 \mathrm{CDC} 1$ & Caddo & 313RSPG & 18 & 320 & 9156 & $1974-$ \\
\hline 352306098282401 & $11 \mathrm{~N}-12 \mathrm{~W}-33$ ACC 1 & Caddo & 313RSPG & 6 & 275 & 9067 & $1988-$ \\
\hline 352551098343901 & $11 \mathrm{~N}-13 \mathrm{~W}-16$ ACA 1 & Caddo & 313RSPG & 16 & 353 & 9157 & $1956-$ \\
\hline 352922098225801 & $12 \mathrm{~N}-11 \mathrm{~W}-29 \mathrm{ACA} 1$ & Caddo & 313RSPG & 14 & 260 & 9159 & 1981- \\
\hline 353137098265801 & $12 \mathrm{~N}-12 \mathrm{~W}-10 \mathrm{DAD} 1$ & Caddo & 313RSPG & - & - & 9162 & $1974-$ \\
\hline 353119098273501 & $12 \mathrm{~N}-12 \mathrm{~W}-15 \mathrm{BAB} 1$ & Caddo & 313RSPG & 6 & 238 & 9029 & $1989-$ \\
\hline 352924098335601 & $12 \mathrm{~N}-13 \mathrm{~W}-27 \mathrm{BAC} 1$ & Caddo & 313RSPG & 18 & 300 & 9160 & $1974-$ \\
\hline
\end{tabular}


Table 1.-Ground-water sites included in the mass measurement network-Continued

\begin{tabular}{|c|c|c|c|c|c|c|c|}
\hline Site-ID & Local well number & County & $\begin{array}{c}\text { Aquifer } \\
\text { code }\end{array}$ & $\begin{array}{c}\text { Diameter } \\
\text { of } \\
\text { casing } \\
\text { (in.) } \\
\end{array}$ & $\begin{array}{c}\text { Depth } \\
\text { of well } \\
(\mathrm{ft})\end{array}$ & $\begin{array}{c}\text { OWRB } \\
\text { identifier }\end{array}$ & $\begin{array}{c}\text { Period } \\
\text { of } \\
\text { record }\end{array}$ \\
\hline 353130097415501 & $12 \mathrm{~N}-05 \mathrm{~W}-11 \mathrm{CDA} 1$ & Canadian & 110ALVM & - & 43.0 & 9164 & $1977-$ \\
\hline 353105097454001 & $12 \mathrm{~N}-05 \mathrm{~W}-18$ ADA 1 & Canadian & 110ALVM & 12 & 45.0 & 9163 & $1977-$ \\
\hline 353210097485601 & $12 \mathrm{~N}-06 \mathrm{~W}-10$ AAB 1 & Canadian & 110ALVM & - & 55.0 & 9165 & $1978-$ \\
\hline 353236097551801 & $12 \mathrm{~N}-07 \mathrm{~W}-03 \mathrm{DAB} 1$ & Canadian & 110ALVM & - & 50.0 & 9166 & $1978-$ \\
\hline 353315097521001 & $13 N-06 \mathrm{~W}-31$ DDA 1 & Canadian & 110ALVM & - & 45.0 & 9167 & $1977-$ \\
\hline 353446098033701 & $13 \mathrm{~N}-08 \mathrm{~W}-28 \mathrm{BBA} 1$ & Canadian & 110ALVM & - & - & 9168 & $1977-$ \\
\hline 354058098101601 & $14 \mathrm{~N}-09 \mathrm{~W}-17 \mathrm{DDD} 1$ & Canadian & 110TRRCL & - & 77.0 & 9169 & $1977-$ \\
\hline 341526097165101 & 03S-01W-35 BBC 1 & Carter & $318 \mathrm{WCHT}$ & - & - & 9170 & $1976-$ \\
\hline 355407094593701 & $17 \mathrm{~N}-22 \mathrm{E}-32 \mathrm{CDC} 1$ & Cherokee & - & - & 54.00 & 9171 & $1985-$ \\
\hline 355920095111001 & $18 \mathrm{~N}-20 \mathrm{E}-33 \mathrm{CDD} 1$ & Cherokee & $325 \mathrm{SVNN}$ & - & 65.0 & 9172 & $1979-$ \\
\hline 360151094594501 & $18 \mathrm{~N}-22 \mathrm{E}-17 \mathrm{CCA} 1$ & Cherokee & - & - & 155 & 9173 & $1981-$ \\
\hline 340201095531501 & 06S- $14 \mathrm{E}-18 \mathrm{CBB} 1$ & Choctaw & - & - & - & 9174 & $1976-$ \\
\hline 340326095171901 & 06S- 19E-02 CDD 1 & Choctaw & - & - & - & 9175 & $1981-$ \\
\hline 340326095175101 & 06S- 19E-03 DDD 2 & Choctaw & 218ALRS & - & 320 & 9176 & $1981-$ \\
\hline 363410102560001 & $01 \mathrm{~N}-01 \mathrm{E}-10 \mathrm{AAD} 1$ & Cimarron & 221EXTR & 2 & 662 & 9205 & $1970-$ \\
\hline 363240102560001 & $01 \mathrm{~N}-01 \mathrm{E}-15 \mathrm{BBB} 1$ & Cimarron & 121OGLL & 18 & 412 & 1988 & $1967-$ \\
\hline 363120102545001 & $01 \mathrm{~N}-01 \mathrm{E}-25 \mathrm{CBB} 1$ & Cimarron & $217 \mathrm{CYNN}$ & 16 & 400 & 1996 & $1967-$ \\
\hline 363030102571001 & $01 \mathrm{~N}-01 \mathrm{E}-33$ ACD 1 & Cimarron & 121OGLL & 16 & 316 & 9181 & $1966-$ \\
\hline 363050102551001 & $01 \mathrm{~N}-01 \mathrm{E}-35$ ABC 1 & Cimarron & 121OGLL & 18 & 243 & 2001 & $1967-$ \\
\hline 363410102513001 & $01 \mathrm{~N}-02 \mathrm{E}-09$ BCB 1 & Cimarron & 121OGLL & 16 & 170 & 2008 & $1967-$ \\
\hline 363430102474001 & $01 \mathrm{~N}-02 \mathrm{E}-12 \mathrm{ABB} 1$ & Cimarron & $121 \mathrm{OGLL}$ & 16 & 290 & 9206 & $1967-$ \\
\hline 363330102482001 & $01 \mathrm{~N}-02 \mathrm{E}-13 \mathrm{BBC} 1$ & Cimarron & 121OGLL & 16 & 340 & 9200 & $1967-$ \\
\hline 363310102511001 & $01 \mathrm{~N}-02 \mathrm{E}-16 \mathrm{BDC} 1$ & Cimarron & $217 \mathrm{CYNN}$ & 16 & 448 & 9199 & $1967-$ \\
\hline 363220102482001 & $01 \mathrm{~N}-02 \mathrm{E}-24 \mathrm{CBB} 1$ & Cimarron & $217 \mathrm{CYNN}$ & 16 & 401 & 2019 & $1967-$ \\
\hline 363120102502001 & $01 \mathrm{~N}-02 \mathrm{E}-27 \mathrm{BCC} 1$ & Cimarron & 121OGLL & - & 102 & 9190 & $1966-$ \\
\hline 363150102522001 & $01 \mathrm{~N}-02 \mathrm{E}-29 \mathrm{BBA} 1$ & Cimarron & 1210GLL & 2 & 454 & 9195 & $1970-$ \\
\hline 363130102534001 & $01 \mathrm{~N}-02 \mathrm{E}-30 \mathrm{BCC} 1$ & Cimarron & $217 \mathrm{CYNN}$ & 16 & 227 & 2022 & $1967-$ \\
\hline 363410102452001 & $01 \mathrm{~N}-03 \mathrm{E}-08$ ADB 1 & Cimarron & - & 16 & 703 & 9203 & $1967-$ \\
\hline 363254102460701 & $01 \mathrm{~N}-03 \mathrm{E}-17 \mathrm{CBC} 1$ & Cimarron & $217 \mathrm{CYNN}$ & - & 252 & 9198 & $1968-$ \\
\hline 363150102414001 & $01 N-03 E-25$ BBB 1 & Cimarron & $217 \mathrm{CYNN}$ & - & 425 & 2038 & $1966-$ \\
\hline 363110102461001 & $01 \mathrm{~N}-03 \mathrm{E}-29 \mathrm{CCB} 1$ & Cimarron & 221MRSN & 16 & 444 & 2041 & $1967-$ \\
\hline 363014102443001 & $01 \mathrm{~N}-03 \mathrm{E}-33$ DCC 1 & Cimarron & 121OGLL & - & 62.0 & 9178 & $1938-$ \\
\hline 363030102423001 & $01 \mathrm{~N}-03 \mathrm{E}-35 \mathrm{CCA} 1$ & Cimarron & 121OGLL & 16 & 120 & 9180 & $1967-$ \\
\hline 363120102354001 & $01 \mathrm{~N}-04 \mathrm{E}-26 \mathrm{ADC} 1$ & Cimarron & $1210 \mathrm{GLL}$ & 16 & 295 & 9189 & $1967-$ \\
\hline 363120102301001 & $01 \mathrm{~N}-05 \mathrm{E}-27$ DBD 1 & Cimarron & 121OGLL & 16 & 190 & 9188 & $1967-$ \\
\hline 363100102330001 & $01 \mathrm{~N}-05 \mathrm{E}-32 \mathrm{BBA} 1$ & Cimarron & 121OGLL & 16 & 223 & 9183 & $1966-$ \\
\hline 363010102303001 & $01 \mathrm{~N}-05 \mathrm{E}-34 \mathrm{CDD} 1$ & Cimarron & 121OGLL & - & 250 & 9177 & $1967-$ \\
\hline 363030102292001 & $01 N-05 E-35$ DBC 1 & Cimarron & 121OGLL & 16 & 210 & 2052 & $1967-$ \\
\hline 363517102262701 & $01 \mathrm{~N}-06 \mathrm{E}-05 \mathrm{BBA} 1$ & Cimarron & 121OGLL & 5 & 126 & 9208 & $1967-$ \\
\hline 363110102230001 & $01 N-06 E-26 \mathrm{CCC} 1$ & Cimarron & 121OGLL & 16 & 172 & 9186 & $1967-$ \\
\hline
\end{tabular}


Table 1.-Ground-water sites included in the mass measurement network-Continued

\begin{tabular}{|c|c|c|c|c|c|c|c|}
\hline Site-ID & Local well number & County & $\begin{array}{c}\text { Aquifer } \\
\text { code }\end{array}$ & $\begin{array}{c}\text { Diameter } \\
\text { of } \\
\text { casing } \\
\text { (in.) }\end{array}$ & $\begin{array}{l}\text { Depth } \\
\text { of well } \\
\text { (ft) }\end{array}$ & $\begin{array}{c}\text { OWRB } \\
\text { identifier }\end{array}$ & $\begin{array}{l}\text { Period } \\
\text { of } \\
\text { record }\end{array}$ \\
\hline 363130102184001 & $01 \mathrm{~N}-07 \mathrm{E}-28$ BAD 1 & Cimarron & 121OGLL & - & 221 & 9192 & 1968 \\
\hline 363440102115001 & $01 \mathrm{~N}-08 \mathrm{E}-04 \mathrm{DDB} 1$ & Cimarron & 121OGLL & 16 & 465 & 9207 & $1967-$ \\
\hline 363351102050701 & $01 \mathrm{~N}-09 \mathrm{E}-10 \mathrm{CBC} 1$ & Cimarron & 121OGLL & 2 & 423 & 9202 & 1970 \\
\hline 363348102035201 & $01 \mathrm{~N}-09 \mathrm{E}-11 \mathrm{CBD} 1$ & Cimarron & 121OGLL & 16 & 415 & 9201 & $1969-$ \\
\hline 363110102040001 & $01 \mathrm{~N}-09 \mathrm{E}-27$ DDA 1 & Cimarron & 121OGLL & - & 401 & 9184 & $1967-$ \\
\hline 363110102064001 & $01 \mathrm{~N}-09 \mathrm{E}-29 \mathrm{DCB} 1$ & Cimarron & 1210GLL & 16 & 420 & 2074 & $1967-$ \\
\hline 363620102541001 & $02 \mathrm{~N}-01 \mathrm{E}-27 \mathrm{CAD} 1$ & Cimarron & - & - & - & 9210 & $1966-$ \\
\hline 364020102473001 & $02 \mathrm{~N}-02 \mathrm{E}-01$ ADB 1 & Cimarron & $211 \mathrm{DKCN}$ & 16 & 243 & 9222 & $1966-$ \\
\hline 363820102510001 & $02 \mathrm{~N}-02 \mathrm{E}-16 \mathrm{CAA} 1$ & Cimarron & - & 16 & 515 & 2081 & $1967-$ \\
\hline 363660102476001 & $02 \mathrm{~N}-02 \mathrm{E}-25 \mathrm{BAD} 1$ & Cimarron & $217 \mathrm{CYNN}$ & 16 & 249 & 9213 & $1967-$ \\
\hline 364030102253001 & $02 \mathrm{~N}-06 \mathrm{E}-04 \mathrm{BBB} 1$ & Cimarron & 1210GLL & - & - & 9223 & $1967-$ \\
\hline 363920102184001 & 02N-07E-09 ACC 1 & Cimarron & 121OGLL & 16 & 220 & 2117 & $1967-$ \\
\hline 363800102150001 & $02 \mathrm{~N}-07 \mathrm{E}-13$ DDD 1 & Cimarron & 121OGLL & 16 & 393 & 5600 & $1967-$ \\
\hline 363650102161001 & $02 \mathrm{~N}-07 \mathrm{E}-26$ AAC 1 & Cimarron & 121OGLL & 16 & 375 & 2127 & $1967-$ \\
\hline 363850102134001 & $02 \mathrm{~N}-08 \mathrm{E}-17 \mathrm{BBA} 1$ & Cimarron & 121OGLL & 16 & 407 & 9219 & $1967-$ \\
\hline 363730102142001 & $02 \mathrm{~N}-08 \mathrm{E}-19$ DBB 1 & Cimarron & 121OGLL & 16 & 320 & 2137 & $1967-$ \\
\hline 363750102110001 & $02 \mathrm{~N}-08 \mathrm{E}-22$ ABC 1 & Cimarron & 121OGLL & 16 & 400 & 9215 & $1967-$ \\
\hline 363700102100001 & $02 \mathrm{~N}-08 \mathrm{E}-26$ ABB 1 & Cimarron & 121OGLL & 16 & 373 & 2146 & $1967-$ \\
\hline 364008102032601 & $02 \mathrm{~N}-09 \mathrm{E}-02$ ACC 1 & Cimarron & 121OGLL & 5 & 135 & 9221 & $1938-$ \\
\hline 363844102060101 & $02 \mathrm{~N}-09 \mathrm{E}-16 \mathrm{BBA} 1$ & Cimarron & - & 5 & 240 & 9218 & $1981-$ \\
\hline 363610102054001 & $02 \mathrm{~N}-09 \mathrm{E}-33 \mathrm{ABB} 1$ & Cimarron & 121OGLL & $\ldots$ & 382 & 2158 & $1967-$ \\
\hline 364130102512001 & $03 \mathrm{~N}-02 \mathrm{E}-28 \mathrm{CCC} 1$ & Cimarron & 121OGLL & 5 & 149 & 9227 & $1967-$ \\
\hline 364420102361001 & $03 \mathrm{~N}-04 \mathrm{E}-11 \mathrm{CAC} 1$ & Cimarron & 121OGLL & 16 & 261 & 2172 & $1978-$ \\
\hline 364150102401001 & $03 \mathrm{~N}-04 \mathrm{E}-30 \mathrm{BDD} 1$ & Cimarron & 121OGLL & 16 & 365 & 2183 & $1967-$ \\
\hline 364100102383001 & $03 N-04 \mathrm{E}-33$ BCC 1 & Cimarron & 121OGLL & 16 & 415 & 2186 & $1967-$ \\
\hline 364520102321001 & $03 \mathrm{~N}-05 \mathrm{E}-05$ DAA 1 & Cimarron & 1210GLL & 16 & 277 & 9237 & $1962-$ \\
\hline 364440102282001 & $03 \mathrm{~N}-05 \mathrm{E}-12$ ACC 1 & Cimarron & 121OGLL & 16 & 250 & 2208 & $1967-$ \\
\hline 364340102231301 & $03 N-05 E-16$ DBA 1 & Cimarron & - & - & - & 9231 & $1967-$ \\
\hline 364539102214601 & $03 \mathrm{~N}-06 \mathrm{E}-01$ ABC 1 & Cimarron & 121OGLL & 16 & 152 & 2231 & $1967-$ \\
\hline 364440102253001 & 03N-06E-09 BCC 1 & Cimarron & 121OGLL & - & 260 & 2243 & $1967-$ \\
\hline 364400102225001 & $03 \mathrm{~N}-06 \mathrm{E}-14$ ABB 1 & Cimarron & 1210GLL & $\ldots$ & 255 & 9233 & $1967-$ \\
\hline 364320102235001 & $03 \mathrm{~N}-06 \mathrm{E}-15$ DCA 1 & Cimarron & 121OGLL & 16 & 278 & 9349 & $1968-$ \\
\hline 364330102253001 & $03 \mathrm{~N}-06 \mathrm{E}-16 \mathrm{CBB} 1$ & Cimarron & 1210GLL & 16 & 216 & 9230 & $1967-$ \\
\hline 364130102195001 & $03 \mathrm{~N}-07 \mathrm{E}-32 \mathrm{BBA} 1$ & Cimarron & 121OGLL & 16 & 189 & 2275 & $1967-$ \\
\hline 364040102182001 & $03 \mathrm{~N}-07 \mathrm{E}-33 \mathrm{DDC} 1$ & Cimarron & 121OGLL & 16 & 190 & 9224 & $1967-$ \\
\hline 364400102022001 & $03 \mathrm{~N}-09 \mathrm{E}-13$ ABB 1 & Cimarron & 231DCKM & 16 & 375 & 9232 & $1967-$ \\
\hline 364918102415201 & $04 \mathrm{~N}-03 \mathrm{E}-11$ DDD 1 & Cimarron & 1210GLL & 16 & 247 & 2285 & $1980-$ \\
\hline 364720102362001 & $04 \mathrm{~N}-04 \mathrm{E}-26 \mathrm{BCB} 1$ & Cimarron & $221 \mathrm{MRSN}$ & 16 & - & 9245 & $1967-$ \\
\hline 364630102343001 & $04 \mathrm{~N}-04 \mathrm{E}-36$ AAC 1 & Cimarron & 1210GLL & 16 & 220 & 2288 & $1967-$ \\
\hline 364910102305501 & $04 \mathrm{~N}-05 \mathrm{E}-15 \mathrm{BBB} 1$ & Cimarron & $217 \mathrm{CYNN}$ & - & 215 & 9251 & $1967-$ \\
\hline
\end{tabular}


Table 1.-Ground-water sites included in the mass measurement network-Continued

\begin{tabular}{|c|c|c|c|c|c|c|c|}
\hline Site-ID & Local well number & County & $\begin{array}{c}\text { Aquifer } \\
\text { code } \\
\end{array}$ & $\begin{array}{c}\text { Diameter } \\
\text { of } \\
\text { casing } \\
\text { (in.) } \\
\end{array}$ & $\begin{array}{c}\text { Depth } \\
\text { of well } \\
(\mathrm{ft})\end{array}$ & $\begin{array}{c}\text { OWRB } \\
\text { identifier }\end{array}$ & $\begin{array}{l}\text { Period } \\
\text { of } \\
\text { record }\end{array}$ \\
\hline 364550102340001 & $04 \mathrm{~N}-05 \mathrm{E}-31 \mathrm{CCD} 1$ & Cimarron & 121OGLL & 16 & 242 & 9239 & $1967-$ \\
\hline 364640102321001 & $04 \mathrm{~N}-05 \mathrm{E}-32$ AAA 1 & Cimarron & 121OGLL & 12 & 228 & 9242 & $1967-$ \\
\hline 364620102282001 & $04 \mathrm{~N}-05 \mathrm{E}-36$ ACB 1 & Cimarron & 121OGLL & 16 & 285 & 2300 & $1967-$ \\
\hline 364950102250001 & 04N-06E-09 ACB 1 & Cimarron & 121OGLL & 8 & 288 & 2305 & $1967-$ \\
\hline 364830102262001 & $04 \mathrm{~N}-06 \mathrm{E}-17 \mathrm{CDC} 1$ & Cimarron & 121OGLL & 16 & 282 & 2313 & $1967-$ \\
\hline 364800102243001 & 04N-06E-22 CBB 1 & Cimarron & 121OGLL & 16 & 283 & 2319 & $1967-$ \\
\hline 364820102231001 & $04 \mathrm{~N}-06 \mathrm{E}-23 \mathrm{BAB} 1$ & Cimarron & 121OGLL & 16 & 227 & 9247 & 1966- \\
\hline 364720102222001 & $04 \mathrm{~N}-06 \mathrm{E}-25 \mathrm{BBC} 1$ & Cimarron & 121OGLL & 12 & 193 & 2325 & $1967-$ \\
\hline 364650102232001 & $04 \mathrm{~N}-06 \mathrm{E}-26 \mathrm{CBC} 1$ & Cimarron & 121OGLL & 16 & 207 & 2326 & $1966-$ \\
\hline 365030102175001 & 04N-07E-03 CBA 1 & Cimarron & 121OGLL & - & 265 & 9256 & $1967-$ \\
\hline 365010102204001 & 04N-07E-07 ABB 1 & Cimarron & 121OGLL & 18 & 253 & 9255 & $1967-$ \\
\hline 364850102184001 & $04 \mathrm{~N}-07 \mathrm{E}-16$ ACC 1 & Cimarron & 121OGLL & 16 & 204 & 2353 & $1967-$ \\
\hline 364850102212001 & $04 \mathrm{~N}-07 \mathrm{E}-18 \mathrm{CBB} 1$ & Cimarron & 121OGLL & 16 & 229 & 2354 & $1967-$ \\
\hline 365100102125001 & 04N-08E-05 AAB 1 & Cimarron & 1210GLL & 16 & 334 & 2358 & $1967-$ \\
\hline 364950102031001 & $04 \mathrm{~N}-09 \mathrm{E}-11$ ADD 1 & Cimarron & 231DCKM & - & 268 & 9253 & $1967-$ \\
\hline 365110102024001 & $05 N-09 E-36$ CBC 1 & Cimarron & 231DCKM & 16 & 316 & 9258 & $1967-$ \\
\hline 365730102132001 & $06 \mathrm{~N}-08 \mathrm{E}-29 \mathrm{BDC} 1$ & Cimarron & 1210GLL & 16 & 325 & 9348 & $1967-$ \\
\hline 365740102054901 & $06 \mathrm{~N}-09 \mathrm{E}-28 \mathrm{BCA} 1$ & Cimarron & 121OGLL & 5 & 300 & 9259 & $1980-$ \\
\hline 365934102014401 & $06 \mathrm{~N}-10 \mathrm{E}-18 \mathrm{BBB} 1$ & Cimarron & 121OGLL & 2 & 272 & 9800 & $1970_{-}^{-}$ \\
\hline 365710102013901 & $06 \mathrm{~N}-10 \mathrm{E}-30 \mathrm{CCC} 1$ & Cimarron & 121OGLL & 16 & 365 & 9789 & $1966-$ \\
\hline 350430097175501 & $07 \mathrm{~N}-01 \mathrm{~W}-15 \mathrm{CCC} 1$ & Cleveland & $317 \mathrm{GBWG}$ & - & 220 & 9262 & $1981-$ \\
\hline 350338097180301 & $07 \mathrm{~N}-01 \mathrm{~W}-21$ DDD 1 & Cleveland & $317 \mathrm{GBWG}$ & - & 585 & 9260 & $1984-$ \\
\hline 350351097165201 & $07 \mathrm{~N}-01 \mathrm{~W}-23 \mathrm{CBC} 1$ & Cleveland & - & - & 166 & 9261 & $1981-$ \\
\hline 350812097180301 & $07 \mathrm{~N}-01 \mathrm{~W}-28$ ADD 1 & Cleveland & - & - & 220 & 9264 & $1981-$ \\
\hline 350628097230401 & 07N-02W-02 CBD 1 & Cleveland & - & - & 84.0 & 9263 & $1981-$ \\
\hline 351149097210501 & 08N-01W-06 CBB 1 & Cleveland & - & - & - & 9267 & $1983-$ \\
\hline 350845097181101 & $08 \mathrm{~N}-01 \mathrm{~W}-28$ AAB 1 & Cleveland & - & 5 & 260 & 9265 & $1984-$ \\
\hline 350845097214501 & $08 \mathrm{~N}-02 \mathrm{~W}-25 \mathrm{BAA} 1$ & Cleveland & $317 \mathrm{GBWG}$ & - & 480 & 9266 & $1979-$ \\
\hline 351512097292801 & $09 \mathrm{~N}-03 \mathrm{~W}-14 \mathrm{CBA} 1$ & Cleveland & - & 6 & 700 & 9268 & $1984-$ \\
\hline 351531097331801 & $09 \mathrm{~N}-03 \mathrm{~W}-18$ ABC 1 & Cleveland & - & - & 141 & 9269 & $1984-$ \\
\hline 352137097165201 & $10 \mathrm{~N}-01 \mathrm{~W}-11 \mathrm{BBC} 1$ & Cleveland & - & - & 100 & 9271 & $1979-$ \\
\hline 351913097262501 & $10 \mathrm{~N}-02 \mathrm{~W}-20 \mathrm{CCC} 1$ & Cleveland & - & - & 210 & 9270 & $1980-$ \\
\hline 343634096204901 & $02 \mathrm{~N}-09 \mathrm{E}-27 \mathrm{CDD} 1$ & Coal & $325 \mathrm{SVNN}$ & - & 23.0 & 9272 & $1981-$ \\
\hline 342911098374701 & $01 \mathrm{~S}-14 \mathrm{~W}-12 \mathrm{BCC} 1$ & Comanche & - & - & - & 9273 & $1981-$ \\
\hline 344630098095901 & 04N-09W-32 DBB 1 & Comanche & - & - & - & 9275 & $1983-$ \\
\hline 344630098083201 & $04 \mathrm{~N}-09 \mathrm{~W}-33$ DAA 1 & Comanche & - & - & - & 9274 & $1983-$ \\
\hline 342232098281901 & 02S-12W-21 BBB 1 & Cotton & - & - & 一 & 9277 & $1983-$ \\
\hline 341625098170201 & 03S-10W-30 AAB 1 & Cotton & - & - & - & 9276 & $1979-$ \\
\hline 363220095132701 & $24 \mathrm{~N}-20 \mathrm{E}-30 \mathrm{BCA} 1$ & Craig & $331 \mathrm{BOON}$ & - & - & 9278 & $1979-$ \\
\hline 364438095043501 & $26 \mathrm{~N}-21 \mathrm{E}-08 \mathrm{DDD} 1$ & Craig & $325 \mathrm{SVNN}$ & - & - & 9279 & $1977-$ \\
\hline
\end{tabular}


Table 1.-Ground-water sites included in the mass measurement network-Continued

\begin{tabular}{|c|c|c|c|c|c|c|c|c|}
\hline Site-ID & Local well number & & County & $\begin{array}{c}\text { Aquifer } \\
\text { code }\end{array}$ & $\begin{array}{c}\text { Diameter } \\
\text { of } \\
\text { casing } \\
\text { (in.) } \\
\end{array}$ & $\begin{array}{c}\text { Depth } \\
\text { of well } \\
(\mathrm{ft})\end{array}$ & $\begin{array}{c}\text { OWRB } \\
\text { identifier }\end{array}$ & $\begin{array}{c}\text { Period } \\
\text { of } \\
\text { record }\end{array}$ \\
\hline 360717096202801 & $19 \mathrm{~N}-09 \mathrm{E}-15 \mathrm{CCA}$ & 1 & Creek & - & - & - & 9281 & $1980-$ \\
\hline 352749098422001 & $11 \mathrm{~N}-14 \mathrm{~W}-05 \mathrm{BAA}$ & 1 & Custer & 313RSPG & - & - & 9847 & $1979-$ \\
\hline 352834098415201 & $12 \mathrm{~N}-14 \mathrm{~W}-32 \mathrm{AAC}$ & 1 & Custer & 313RSPG & 6 & 320 & 9246 & $1989-$ \\
\hline 352804098401801 & $12 \mathrm{~N}-14 \mathrm{~W}-34 \mathrm{CCA}$ & 1 & Custer & 313RSPG & 6.63 & 440 & 9244 & $1989-$ \\
\hline 353241098500201 & $12 \mathrm{~N}-15 \mathrm{~W}-06 \mathrm{BCC}$ & 1 & Custer & 313RSPG & 6 & 340 & 9243 & $1989-$ \\
\hline 352948098443101 & $12 \mathrm{~N}-15 \mathrm{~W}-24 \mathrm{CDB}$ & 1 & Custer & 313RSPG & 6 & 400 & 9241 & $1989-$ \\
\hline 353019098501801 & $12 \mathrm{~N}-16 \mathrm{~W}-24 \mathrm{AAB}$ & 1 & Custer & 313RSPG & 6 & 300 & 9240 & $1989-$ \\
\hline 353033099014801 & $12 \mathrm{~N}-17 \mathrm{~W}-18$ DDD & 1 & Custer & 313RSPG & 7 & 520 & 9238 & $1989-$ \\
\hline 353645098440401 & $13 \mathrm{~N}-14 \mathrm{~W}-07 \mathrm{CCA}$ & 1 & Custer & 313RSPG & 6 & 300 & 9235 & $1989-$ \\
\hline 353319098393401 & $13 N-14 W-35$ CAD & 1 & Custer & 313RSPG & 6.63 & 285 & 9234 & $1989-$ \\
\hline 353436098464201 & $13 \mathrm{~N}-15 \mathrm{~W}-27 \mathrm{ACA}$ & 1 & Custer & 313RSPG & 9.875 & 360 & 9225 & $1990_{-}$ \\
\hline 353504099003201 & $13 N-17 W-21$ DBD & 1 & Custer & 313RSPG & 6.625 & 362 & 9220 & $1989-$ \\
\hline 353346098582301 & $13 \mathrm{~N}-17 \mathrm{~W}-35 \mathrm{AAC}$ & 1 & Custer & 313RSPG & 6 & 470 & 9217 & $1989-$ \\
\hline 353613099065601 & $13 N-18 W-16$ ACD & 1 & Custer & 313RSPG & 6.625 & 500 & 9216 & $1989-$ \\
\hline 354109098431501 & $14 \mathrm{~N}-14 \mathrm{~W}-18 \mathrm{DADD}$ & 1 & Custer & 313RSPG & 4 & 148 & 9214 & $1990-$ \\
\hline 354015098423001 & $14 \mathrm{~N}-14 \mathrm{~W}-20 \mathrm{DCA}$ & 1 & Custer & 313RSPG & 6 & 225 & 9212 & $1989-$ \\
\hline 353926098505801 & $14 N-16 W-25$ DBD & 1 & Custer & 313RSPG & 6 & 400 & 9211 & $1990-$ \\
\hline 354238099094801 & $14 \mathrm{~N}-18 \mathrm{~W}-07 \mathrm{BBBB}$ & 1 & Custer & 313RSPG & 4 & 186 & 9209 & $1990^{-}$ \\
\hline 354545098514101 & $15 \mathrm{~N}-16 \mathrm{~W}-24 \mathrm{BCC}$ & 1 & Custer & 313RSPG & 6.625 & 305 & 9248 & $1989-$ \\
\hline 354555098593001 & $15 \mathrm{~N}-17 \mathrm{~W}-22 \mathrm{ACA}$ & 1 & Custer & 313RSPG & 6 & 360 & 9249 & $1990-$ \\
\hline 362554094580201 & $23 \mathrm{~N}-22 \mathrm{E}-33 \mathrm{ACC}$ & 1 & Delaware & - & - & - & 9287 & $1979-$ \\
\hline 355352098391401 & $16 \mathrm{~N}-14 \mathrm{~W}-02 \mathrm{ABA}$ & 1 & Dewey & - & 4 & 253.00 & 9310 & $1988-$ \\
\hline 355114099011101 & $16 \mathrm{~N}-17 \mathrm{~W}-21 \mathrm{BBD}$ & 1 & Dewey & 313RSPG & 6 & 400 & 9309 & $1989-$ \\
\hline 354949099062101 & $16 \mathrm{~N}-18 \mathrm{~W}-27 \mathrm{CDB}$ & 1 & Dewey & 313RSPG & 6 & 405 & 9308 & $1990-$ \\
\hline 355816098432401 & $17 \mathrm{~N}-14 \mathrm{~W}-05 \mathrm{CCC}$ & 1 & Dewey & 313RSPG & 一 & 350 & 9288 & $1976-$ \\
\hline 360316098442001 & $18 \mathrm{~N}-14 \mathrm{~W}-07 \mathrm{BBD}$ & 1 & Dewey & 313RSPG & - & 400 & 9289 & 1979 \\
\hline 360015098573601 & $18 \mathrm{~N}-17 \mathrm{~W}-25 \mathrm{DBD}$ & 1 & Dewey & 313RSPG & - & - & 9252 & $1989-$ \\
\hline 360539098402001 & $19 \mathrm{~N}-14 \mathrm{~W}-27 \mathrm{ADD}$ & 1 & Dewey & 313RSPG & - & 190 & 9291 & $1979-$ \\
\hline 360850099141001 & $19 \mathrm{~N}-19 \mathrm{~W}-04 \mathrm{CCA}$ & 1 & Dewey & 121OGLL & - & 85 & 9294 & $1981-$ \\
\hline 360759099195601 & $19 \mathrm{~N}-20 \mathrm{~W}-09 \mathrm{DDB}$ & 1 & Dewey & 121OGLL & 5 & - & 9293 & $1980-$ \\
\hline 360113099501601 & $18 \mathrm{~N}-25 \mathrm{~W}-23 \mathrm{CAA}$ & 1 & Ellis & 121OGLL & 14 & 91 & 2923 & $1980-$ \\
\hline 360137099490801 & $18 \mathrm{~N}-25 \mathrm{~W}-24 \mathrm{BAA}$ & 1 & Ellis & 121OGLL & - & - & 9297 & $1980-$ \\
\hline 360916099391001 & $19 \mathrm{~N}-23 \mathrm{~W}-04 \mathrm{ADB}$ & 1 & Ellis & - & - & - & 2964 & $1980-$ \\
\hline 360922099413401 & $19 \mathrm{~N}-23 \mathrm{~W}-06 \mathrm{ABC}$ & 1 & Ellis & 121OGLL & 16 & 380 & 9317 & $1980-$ \\
\hline 360756099401901 & $19 N-23 W-08$ DDD & 1 & Ellis & 121OGLL & - & - & 9383 & $1980-$ \\
\hline 360758099382201 & $19 \mathrm{~N}-23 \mathrm{~W}-10 \mathrm{DCB}$ & 1 & Ellis & 121OGLL & 16 & 480 & 2970 & $1980-$ \\
\hline 360929099455901 & $19 \mathrm{~N}-24 \mathrm{~W}-04 \mathrm{BAA}$ & 1 & Ellis & 121OGLL & 16 & 273 & 2989 & $1980-$ \\
\hline 360804099475001 & $19 \mathrm{~N}-24 \mathrm{~W}-07 \mathrm{DBC}$ & 1 & Ellis & 121OGLL & 6.52 & 170 & 9311 & $1980-$ \\
\hline 360753099460901 & $19 \mathrm{~N}-24 \mathrm{~W}-09 \mathrm{CBD}$ & 4 & Ellis & 121OGLL & - & 280 & 2990 & $1980-$ \\
\hline 360758099451001 & $19 \mathrm{~N}-24 \mathrm{~W}-10 \mathrm{CCA}$ & 1 & Ellis & 121OGLL & 16 & 366 & 2997 & $1975-$ \\
\hline
\end{tabular}


Table 1.-Ground-water sites included in the mass measurement network-Continued

\begin{tabular}{|c|c|c|c|c|c|c|c|}
\hline Site-ID & Local well number & County & $\begin{array}{c}\text { Aquifer } \\
\text { code }\end{array}$ & $\begin{array}{c}\text { Diameter } \\
\text { of } \\
\text { casing } \\
\text { (in.) }\end{array}$ & $\begin{array}{c}\text { Depth } \\
\text { of well } \\
(\mathrm{ft})\end{array}$ & $\begin{array}{c}\text { OWRB } \\
\text { identifier }\end{array}$ & $\begin{array}{l}\text { Period } \\
\text { of } \\
\text { record }\end{array}$ \\
\hline 360604099483101 & $19 \mathrm{~N}-24 \mathrm{~W}-19 \mathrm{CCC} 1$ & Ellis & 121OGLL & 16 & 174 & 9303 & $1980-$ \\
\hline 360613099422801 & $19 \mathrm{~N}-24 \mathrm{~W}-23 \mathrm{DCA} 1$ & Ellis & 121OGLL & 5 & 325 & 9306 & $1980-$ \\
\hline 360827099485001 & $19 \mathrm{~N}-25 \mathrm{~W}-12$ AAC 1 & Ellis & 121OGLL & - & - & 9315 & $1980-$ \\
\hline 360736099483901 & $19 \mathrm{~N}-25 \mathrm{~W}-13 \mathrm{AAD} 1$ & Ellis & 121OGLL & 16 & 203 & 9307 & $1980-$ \\
\hline 360606099514501 & $19 \mathrm{~N}-25 \mathrm{~W}-22 \mathrm{CCC} 2$ & Ellis & 121OGLL & - & - & 9304 & $1980-$ \\
\hline 360612099500101 & $19 \mathrm{~N}-25 \mathrm{~W}-23$ DCA 1 & Ellis & 121OGLL & 5 & 125 & 3012 & $1980-$ \\
\hline 360558099522601 & $19 \mathrm{~N}-25 \mathrm{~W}-28$ ABB 1 & Ellis & 121OGLL & - & - & 9302 & $1980-$ \\
\hline 360825099582701 & $19 \mathrm{~N}-26 \mathrm{~W}-04$ DAC 1 & Ellis & 121OGLL & - & - & 9314 & 1980 \\
\hline 360822099552201 & $19 \mathrm{~N}-26 \mathrm{~W}-12$ ACA 1 & Ellis & 121OGLL & - & 520 & 9313 & $1980-$ \\
\hline 360520099562601 & $19 \mathrm{~N}-26 \mathrm{~W}-26 \mathrm{DCA} 1$ & Ellis & 121OGLL & 6.63 & 65.0 & 9300 & $1980-$ \\
\hline 360520099583401 & $19 \mathrm{~N}-26 \mathrm{~W}-28$ DCA 1 & Ellis & $1210 G L L$ & 6.63 & 455 & 9301 & $1980-$ \\
\hline 360427099572801 & $19 \mathrm{~N}-26 \mathrm{~W}-34$ DCA 1 & Ellis & 121OGLL & 6.63 & 215 & 9299 & $1980-$ \\
\hline 360420099560001 & $19 \mathrm{~N}-26 \mathrm{~W}-36 \mathrm{CCC} 1$ & Ellis & 121 OGLL & - & - & 9298 & $1980-$ \\
\hline 360936099332901 & $20 \mathrm{~N}-22 \mathrm{~W}-32 \mathrm{DCA} 1$ & Ellis & 121OGLL & 16 & 420 & 3025 & $1980-$ \\
\hline 361420099411001 & $20 \mathrm{~N}-23 \mathrm{~W}-06 \mathrm{ADD} 1$ & Ellis & 121OGLL & - & - & 9329 & $1980-$ \\
\hline 361154099415801 & $20 \mathrm{~N}-23 \mathrm{~W}-19 \mathrm{BCA} 1$ & Ellis & 121OGLL & - & - & 9323 & $1980-$ \\
\hline 361127099374301 & $20 \mathrm{~N}-23 \mathrm{~W}-23 \mathrm{CCA} 1$ & Ellis & 121OGLL & - & - & 9322 & $1980-$ \\
\hline 361405099443301 & $20 \mathrm{~N}-24 \mathrm{~W}-03$ DDB 1 & Ellis & 121OGLL & 6.63 & 180 & 4315 & $1980-$ \\
\hline 361335099475301 & $20 \mathrm{~N}-24 \mathrm{~W}-07$ ACA 1 & Ellis & 121OGLL & 6.63 & 240 & 3043 & $1980-$ \\
\hline 361300099453801 & $20 \mathrm{~N}-24 \mathrm{~W}-16$ BAA 2 & Ellis & 121OGLL & - & - & 9382 & $1980-$ \\
\hline 360958099432901 & $20 \mathrm{~N}-24 \mathrm{~W}-35$ ADC 1 & Ellis & 121OGLL & 16 & 283 & 3054 & $1975-$ \\
\hline 361429099503501 & $20 \mathrm{~N}-25 \mathrm{~W}-02 \mathrm{BCA} 1$ & Ellis & 121OGLL & 6 & 300 & 9330 & 1980 \\
\hline 361431099523801 & $20 \mathrm{~N}-25 \mathrm{~W}-04 \mathrm{BCA} 1$ & Ellis & 121OGLL & 10 & - & 9332 & $1980-$ \\
\hline 361403099533301 & $20 \mathrm{~N}-25 \mathrm{~W}-05 \mathrm{CAC} 1$ & Ellis & 121OGLL & 12 & - & 9327 & 1980 \\
\hline 361429099544001 & $20 \mathrm{~N}-25 \mathrm{~W}-06 \mathrm{BDB} 1$ & Ellis & 121OGLL & 12 & 232 & 9331 & $1981-$ \\
\hline 361256099534501 & $20 \mathrm{~N}-25 \mathrm{~W}-17 \mathrm{BBA} 1$ & Ellis & 121OGLL & - & 75.0 & 9376 & $1981-$ \\
\hline 361156099504001 & $20 \mathrm{~N}-25 \mathrm{~W}-23 \mathrm{BBC} 1$ & Ellis & 121OGLL & - & - & 9324 & $1981-$ \\
\hline 361211099573801 & $20 \mathrm{~N}-26 \mathrm{~W}-15 \mathrm{DCC} 1$ & Ellis & 121OGLL & 16 & 380 & 3071 & $1976-$ \\
\hline 361007099572201 & $20 \mathrm{~N}-26 \mathrm{~W}-34$ ADB 1 & Ellis & 121OGLL & 5 & 325 & 9321 & $1981-$ \\
\hline 360822099551301 & $20 \mathrm{~N}-26 \mathrm{~W}-36$ DDB 1 & Ellis & 121OGLL & - & - & 9312 & $1981-$ \\
\hline 361852099412801 & $21 \mathrm{~N}-23 \mathrm{~W}-08 \mathrm{BCA} 1$ & Ellis & 121OGLL & - & 193 & 9353 & $1980-$ \\
\hline 361545099361601 & $21 N-23 W-25$ DDA 1 & Ellis & 121OGLL & - & 230 & 9367 & $1980-$ \\
\hline 361629099424301 & $21 \mathrm{~N}-23 \mathrm{~W}-30 \mathrm{BBB} 1$ & Ellis & 121OGLL & 5 & 170 & 3097 & $1980-$ \\
\hline 361924099430701 & $21 \mathrm{~N}-24 \mathrm{~W}-01 \mathrm{DBD} 2$ & Ellis & 121OGLL & 6 & 180 & 9356 & $1980-$ \\
\hline 362017099455101 & $21 \mathrm{~N}-24 \mathrm{~W}-03 \mathrm{BBB} 2$ & Ellis & 121OGLL & 8 & 78.0 & 9359 & $1980-$ \\
\hline 361911099481901 & $21 \mathrm{~N}-24 \mathrm{~W}-06$ DCD 2 & Ellis & 121OGLL & 8 & 167 & 9355 & $1980-$ \\
\hline 361817099461301 & $21 \mathrm{~N}-24 \mathrm{~W}-09 \mathrm{DDC} 1$ & Ellis & 121OGLL & 16 & 217 & 9351 & $1980-$ \\
\hline 361905099455801 & $21 \mathrm{~N}-24 \mathrm{~W}-10 \mathrm{BBB} 1$ & Ellis & $1210 G L L$ & 10 & 60.0 & 3109 & $1980-$ \\
\hline 361815099444201 & $21 \mathrm{~N}-24 \mathrm{~W}-11 \mathrm{CCC} 1$ & Ellis & 112TRRCH & - & - & 9366 & $1979-$ \\
\hline 361648099442601 & $21 \mathrm{~N}-24 \mathrm{~W}-23 \mathrm{CAD} 1$ & Ellis & 110TRRCL & - & $\ldots$ & 9347 & 1980 \\
\hline
\end{tabular}


Table 1.-Ground-water sites included in the mass measurement network-Continued

\begin{tabular}{|c|c|c|c|c|c|c|c|}
\hline Site-ID & Local well number & County & $\begin{array}{c}\text { Aquifer } \\
\text { code }\end{array}$ & $\begin{array}{c}\text { Diameter } \\
\text { of } \\
\text { casing } \\
\text { (in.) } \\
\end{array}$ & $\begin{array}{c}\text { Depth } \\
\text { of well } \\
(\mathrm{ft})\end{array}$ & $\begin{array}{c}\text { OWRB } \\
\text { identifier }\end{array}$ & $\begin{array}{c}\text { Period } \\
\text { of } \\
\text { record }\end{array}$ \\
\hline 361646099434301 & $21 \mathrm{~N}-24 \mathrm{~W}-24 \mathrm{CBC} 1$ & Ellis & 121OGLL & 6.62 & 202 & 9345 & $1980-$ \\
\hline 361552099475201 & $21 \mathrm{~N}-24 \mathrm{~W}-29 \mathrm{CAC} 1$ & Ellis & 121OGLL & 6.62 & 210 & 9338 & $1980-$ \\
\hline 361455099490201 & $21 N-24 W-31$ CCA 1 & Ellis & 121OGLL & 5 & 230 & 9333 & $1980-$ \\
\hline 361735099513501 & $21 \mathrm{~N}-25 \mathrm{~W}-15$ DDB 1 & Ellis & 110ALVM & 16 & 225 & 3134 & $1980-$ \\
\hline 361737099531301 & $21 \mathrm{~N}-25 \mathrm{~W}-16 \mathrm{CCA} 1$ & Ellis & 110ALVM & - & 240 & 3136 & $1980-$ \\
\hline 361635099543101 & $21 \mathrm{~N}-25 \mathrm{~W}-20 \mathrm{CCC} 1$ & Ellis & 110TRRCL & 一 & - & 9343 & $1980-$ \\
\hline 361641099513801 & $21 \mathrm{~N}-25 \mathrm{~W}-22$ DDB 1 & Ellis & $1210 \mathrm{OGL}$ & 16 & 215 & 3141 & $1970-$ \\
\hline 361634099501301 & $21 \mathrm{~N}-25 \mathrm{~W}-24 \mathrm{CCC} 1$ & Ellis & 121OGLL & 16 & 240 & 3143 & $1976-$ \\
\hline 361550099530801 & $21 \mathrm{~N}-25 \mathrm{~W}-28 \mathrm{CDB} 1$ & Ellis & 121OGLL & 一 & - & 9337 & $1980-$ \\
\hline 361558099524101 & $21 \mathrm{~N}-25 \mathrm{~W}-28$ DBD 1 & Ellis & 121OGLL & - & 318 & 9339 & $1979-$ \\
\hline 361622099552601 & $21 \mathrm{~N}-25 \mathrm{~W}-30$ BBD 4 & Ellis & 121OGLL & 16 & 297 & 9340 & $1980-$ \\
\hline 361456099542401 & $21 \mathrm{~N}-25 \mathrm{~W}-32 \mathrm{CCA} 1$ & Ellis & 121OGLL & 16 & 200 & 9334 & $1980-$ \\
\hline 361501099521201 & $21 \mathrm{~N}-25 \mathrm{~W}-34 \mathrm{CBD} 1$ & Ellis & 121OGLL & 16 & 238 & 3153 & $1980-$ \\
\hline 361534099501401 & $21 \mathrm{~N}-25 \mathrm{~W}-36 \mathrm{BBB} 1$ & Ellis & 121OGLL & - & 105 & 9336 & $1980-$ \\
\hline 361831099590901 & $21 \mathrm{~N}-26 \mathrm{~W}-09 \mathrm{DAC} 3$ & Ellis & 121OGLL & - & 380 & 3161 & $1980-$ \\
\hline 361720099590201 & $21 \mathrm{~N}-26 \mathrm{~W}-21$ AAA 1 & Ellis & 1210GLL & - & 324 & 3171 & $1980-$ \\
\hline 361647099554901 & $21 \mathrm{~N}-26 \mathrm{~W}-24 \mathrm{DDB} 1$ & Ellis & 110ALVM & 14 & 50.0 & 9346 & $1980-$ \\
\hline 362451099372701 & $22 \mathrm{~N}-23 \mathrm{~W}-02$ ADD 1 & Ellis & 121OGLL & - & 112 & 9379 & $1980-$ \\
\hline 362450099383101 & $22 \mathrm{~N}-23 \mathrm{~W}-03$ ADD 1 & Ellis & 121OGLL & - & 115 & 9378 & $1980-$ \\
\hline 362415099393901 & $22 \mathrm{~N}-23 \mathrm{~W}-09$ AAB 1 & Ellis & 121OGLL & - & 210 & 9377 & $1980-$ \\
\hline 362340099373501 & $22 \mathrm{~N}-23 \mathrm{~W}-11$ DDB 1 & Ellis & 1210GLL & - & 140 & 9374 & $1980-$ \\
\hline 362254099364001 & $22 \mathrm{~N}-23 \mathrm{~W}-13$ DBD 1 & Ellis & 1210GLL & 16 & 123 & 9373 & $1980-$ \\
\hline 362249099405701 & $22 \mathrm{~N}-23 \mathrm{~W}-17$ DBD 1 & Ellis & 121OGLL & - & - & 9357 & $1980-$ \\
\hline 362201099415501 & $22 \mathrm{~N}-23 \mathrm{~W}-19$ DAC 3 & Ellis & $1210 \mathrm{OGL}$ & 16 & 175 & 9368 & $1980-$ \\
\hline 362221099383801 & $22 \mathrm{~N}-23 \mathrm{~W}-22$ ADB 1 & Ellis & 110ALVM & - & 123 & 9369 & $1980-$ \\
\hline 362150099370401 & $22 \mathrm{~N}-23 \mathrm{~W}-24 \mathrm{CCA} 3$ & Ellis & 121OGLL & - & 110 & 9354 & $1980-$ \\
\hline 362056099382001 & $22 \mathrm{~N}-23 \mathrm{~W}-26$ DCC 1 & Ellis & 121OGLL & - & - & 9364 & $1980_{-}^{-}$ \\
\hline 362052099410901 & $22 \mathrm{~N}-23 \mathrm{~W}-32$ ABB 1 & Ellis & 121OGLL & - & - & 9363 & $1980-$ \\
\hline 362003099365501 & $22 \mathrm{~N}-23 \mathrm{~W}-36 \mathrm{CDD} 2$ & Ellis & 121OGLL & 5 & 200 & 3214 & $1980-$ \\
\hline 362349099443501 & $22 \mathrm{~N}-24 \mathrm{~W}-11 \mathrm{CBB} 1$ & Ellis & 121OGLL & 5 & 295 & 9375 & $1980-$ \\
\hline 362225099470601 & $22 \mathrm{~N}-24 \mathrm{~W}-20$ ADA 1 & Ellis & 112TRRCH - & - & - & 9370 & $1980-$ \\
\hline 362129099424901 & $22 \mathrm{~N}-24 \mathrm{~W}-25$ ADA 8 & Ellis & $1210 \mathrm{OLL}$ & - & - & 9365 & $1980_{-}^{-}$ \\
\hline 362143099473501 & $22 \mathrm{~N}-24 \mathrm{~W}-29$ ABB 1 & Ellis & 121OGLL & 16 & 239 & 3221 & $1980-$ \\
\hline 362050099475601 & $22 \mathrm{~N}-24 \mathrm{~W}-32 \mathrm{BBA} 1$ & Ellis & 121OGLL & 16 & 310 & 9362 & $1980-$ \\
\hline 362017099450801 & $22 \mathrm{~N}-24 \mathrm{~W}-34 \mathrm{DAC} 1$ & Ellis & 121OGLL & 4 & 139 & 9358 & $1980_{-}^{-}$ \\
\hline 362226099544201 & $22 \mathrm{~N}-25 \mathrm{~W}-19$ AAC 1 & Ellis & 121OGLL & 4.5 & 470 & 9371 & $1980-$ \\
\hline 362236099494001 & $22 \mathrm{~N}-25 \mathrm{~W}-24 \mathrm{ABB} 1$ & Ellis & 121OGLL & - & - & 9372 & $1980-$ \\
\hline 362049099524601 & $22 \mathrm{~N}-25 \mathrm{~W}-33 \mathrm{ABB} 1$ & Ellis & 121OGLL & 6 & 500 & 3244 & $1980^{-}$ \\
\hline 362042099495901 & $22 \mathrm{~N}-25 \mathrm{~W}-36$ BBD 1 & Ellis & 121OGLL & 6.62 & 320 & 9360 & $1980-$ \\
\hline 362410099594601 & $22 \mathrm{~N}-26 \mathrm{~W}-09$ BBD 1 & Ellis & 121OGLL & - & 400 & 3251 & $1980-$ \\
\hline
\end{tabular}


Table 1.-Ground-water sites included in the mass measurement network-Continued

\begin{tabular}{|c|c|c|c|c|c|c|c|}
\hline Site-ID & Local well number & County & $\begin{array}{c}\text { Aquifer } \\
\text { code }\end{array}$ & $\begin{array}{c}\text { Diameter } \\
\text { of } \\
\text { casing } \\
\text { (in.) }\end{array}$ & $\begin{array}{c}\text { Depth } \\
\text { of well } \\
(\mathrm{ft})\end{array}$ & $\begin{array}{c}\text { OWRB } \\
\text { identifier }\end{array}$ & $\begin{array}{l}\text { Period } \\
\text { of } \\
\text { record }\end{array}$ \\
\hline 362148099594301 & $22 \mathrm{~N}-26 \mathrm{~W}-21 \mathrm{CCD} 1$ & Ellis & 121OGLL & 16 & 383 & 3257 & $1980-$ \\
\hline 362847099410401 & $23 \mathrm{~N}-23 \mathrm{~W}-08$ DCC 1 & Ellis & 121OGLL & 16 & 207 & 3266 & $1980-$ \\
\hline 362750099392701 & $23 \mathrm{~N}-23 \mathrm{~W}-22 \mathrm{BBB}$ & Ellis & $1210 \mathrm{GLL}$ & 5 & 260 & 3270 & $1980-$ \\
\hline 362518099421801 & $23 \mathrm{~N}-23 \mathrm{~W}-31 \mathrm{CDD} 1$ & Ellis & $1210 \mathrm{OLL}$ & 16 & 280 & 9380 & $1980-$ \\
\hline 362536099400901 & $23 \mathrm{~N}-23 \mathrm{~W}-33 \mathrm{CAA} 1$ & Ellis & $1210 \mathrm{OLL}$ & - & 184 & 9381 & $1980-$ \\
\hline 363020099432901 & $23 \mathrm{~N}-24 \mathrm{~W}-01 \mathrm{BAC} 1$ & Ellis & 121OGLL & - & 342 & 9352 & $1980-$ \\
\hline 362912099461801 & $23 \mathrm{~N}-24 \mathrm{~W}-09$ ACD 1 & Ellis & $1210 \mathrm{GLL}$ & - & - & 9392 & $1980-$ \\
\hline 362906099450601 & $23 \mathrm{~N}-24 \mathrm{~W}-10 \mathrm{DAB} 1$ & Ellis & 121OGLL & - & - & 9391 & $1980-$ \\
\hline 362933099440101 & $23 \mathrm{~N}-24 \mathrm{~W}-11$ AAB 1 & Ellis & 121OGLL & - & - & 9393 & $1980-$ \\
\hline 362800099434001 & $23 \mathrm{~N}-24 \mathrm{~W}-13 \mathrm{CCA} 1$ & Ellis & 121OGLL & - & - & 9387 & $1980-$ \\
\hline 362833099485901 & $23 \mathrm{~N}-24 \mathrm{~W}-18 \mathrm{BBD} 1$ & Ellis & 121OGLL & - & - & 9389 & $1980-$ \\
\hline 362957099514501 & $23 \mathrm{~N}-25 \mathrm{~W}-03 \mathrm{DDA} 1$ & Ellis & 121OGLL & 5 & 320 & 9395 & $1980-$ \\
\hline 362939099525401 & $23 \mathrm{~N}-25 \mathrm{~W}-04 \mathrm{DCC} 1$ & Ellis & 121OGLL & 5 & 345 & 3296 & $1980-$ \\
\hline 362800099524601 & $23 \mathrm{~N}-25 \mathrm{~W}-16$ DCA 1 & Ellis & 1210GLL & - & 359 & 9388 & $1980-$ \\
\hline 362736099510801 & $23 \mathrm{~N}-25 \mathrm{~W}-23 \mathrm{BCA} 1$ & Ellis & 121OGLL & 6 & 335 & 9384 & $1980-$ \\
\hline 362654099544601 & $23 \mathrm{~N}-25 \mathrm{~W}-30$ AAB 1 & Ellis & 121OGLL & 16 & 480 & 3302 & $1980-$ \\
\hline 362740099563001 & $23 \mathrm{~N}-26 \mathrm{~W}-24 \mathrm{BBD}$ & Ellis & 121OGLL & - & 280 & 3307 & $1980^{-}$ \\
\hline 362647099554901 & $23 \mathrm{~N}-26 \mathrm{~W}-25 \mathrm{AAC} 1$ & Ellis & 121OGLL & 6.62 & 290 & 9350 & $1980-$ \\
\hline 362621099574601 & $23 \mathrm{~N}-26 \mathrm{~W}-26 \mathrm{CBC} 1$ & Ellis & - & - & - & 3309 & $1980-$ \\
\hline 363203099381401 & $24 \mathrm{~N}-23 \mathrm{~W}-26 \mathrm{BBD} 1$ & Ellis & 121OGLL & - & - & 9401 & 1980 \\
\hline 363124099403201 & $24 \mathrm{~N}-23 \mathrm{~W}-28 \mathrm{CCC} 1$ & Ellis & 121OGLL & - & - & 9398 & $1980-$ \\
\hline 363325099481101 & $24 \mathrm{~N}-24 \mathrm{~W}-18$ DAA 1 & Ellis & 121OGLL & - & - & 9407 & $1980-$ \\
\hline 363215099471301 & $24 \mathrm{~N}-24 \mathrm{~W}-20 \mathrm{DDC} 1$ & Ellis & 121OGLL & - & - & 9404 & $1980-$ \\
\hline 363159099471801 & $24 \mathrm{~N}-24 \mathrm{~W}-29$ ACA 1 & Ellis & 121OGLL & 5 & 180 & 9400 & $1981-$ \\
\hline 363448099521801 & $24 \mathrm{~N}-25 \mathrm{~W}-03 \mathrm{CCC} 1$ & Ellis & 121OGLL & - & - & 9409 & 1980 \\
\hline 363511099532601 & $24 \mathrm{~N}-25 \mathrm{~W}-04 \mathrm{CBB} 1$ & Ellis & 121OGLL & 一 & 216 & 9411 & $1980-$ \\
\hline 363316099552501 & $24 \mathrm{~N}-25 \mathrm{~W}-18 \mathrm{CCA} 1$ & Ellis & 121OGLL & 12 & 180 & 3327 & $1981-$ \\
\hline 363254099513201 & $24 \mathrm{~N}-25 \mathrm{~W}-22$ AAC 1 & Ellis & 121OGLL & - & - & 9405 & $1980-$ \\
\hline 363145099515201 & $24 \mathrm{~N}-25 \mathrm{~W}-27 \mathrm{DBB} 1$ & Ellis & 121OGLL & 5 & 260 & 9399 & $1981-$ \\
\hline 363036099510801 & $24 \mathrm{~N}-25 \mathrm{~W}-35 \mathrm{CCA} 1$ & Ellis & 121OGLL & - & - & 9396 & $1980-$ \\
\hline 363501099594201 & $24 \mathrm{~N}-26 \mathrm{~W}-04 \mathrm{CCA} 1$ & Ellis & 121OGLL & 5 & 180 & 9410 & $1980-$ \\
\hline 363407099580101 & $24 \mathrm{~N}-26 \mathrm{~W}-10$ DDB 2 & Ellis & 121OGLL & - & 200 & 3339 & $1980_{-}^{-}$ \\
\hline 363211099573401 & $24 \mathrm{~N}-26 \mathrm{~W}-26 \mathrm{BBA} 1$ & Ellis & 121OGLL & - & 147 & 9402 & $1980-$ \\
\hline 363211099580201 & $24 \mathrm{~N}-26 \mathrm{~W}-27$ AAB 1 & Ellis & 121OGLL & 16 & 160 & 3346 & $1980-$ \\
\hline 363118099595701 & $24 \mathrm{~N}-26 \mathrm{~W}-33$ BBB 1 & Ellis & 121OGLL & 6 & 240 & 3348 & $1980-$ \\
\hline 361907097573601 & $21 \mathrm{~N}-07 \mathrm{~W}-04 \mathrm{CCC} 1$ & Garfield & $318 \mathrm{CDHL}$ & - & 165 & 9414 & $1977-$ \\
\hline 361725098052001 & $21 \mathrm{~N}-08 \mathrm{~W}-18$ DCD 1 & Garfield & 110CMTA & 36 & 12.9 & 9413 & $1950-$ \\
\hline 361651098061001 & $21 \mathrm{~N}-08 \mathrm{~W}-19 \mathrm{CBB} 1$ & Garfield & 110CMTA & 12 & 56 & 9412 & $1954^{-}$ \\
\hline 362736097563901 & $23 \mathrm{~N}-07 \mathrm{~W}-21$ AAD 1 & Garfield & 112TRRCH & - & - & 9422 & $1975-$ \\
\hline 362736097573601 & $23 \mathrm{~N}-07 \mathrm{~W}-21 \mathrm{BBC} 1$ & Garfield & 112TRRCH & - & - & 9423 & $1975-$ \\
\hline
\end{tabular}


Table 1.-Ground-water sites included in the mass measurement network--Continued

\begin{tabular}{|c|c|c|c|c|c|c|c|}
\hline Site-ID & Local well number & County & $\begin{array}{c}\text { Aquifer } \\
\text { code }\end{array}$ & $\begin{array}{c}\text { Diameter } \\
\text { of } \\
\text { casing } \\
\text { (in.) }\end{array}$ & $\begin{array}{c}\text { Depth } \\
\text { of well } \\
\text { (ft) }\end{array}$ & $\begin{array}{c}\text { OWRB } \\
\text { identifier }\end{array}$ & $\begin{array}{l}\text { Period } \\
\text { of } \\
\text { record }\end{array}$ \\
\hline 362650097543901 & $23 \mathrm{~N}-07 \mathrm{~W}-26$ AAB 1 & Garfield & - & - & - & 9416 & $1975-$ \\
\hline 362650097551901 & $23 \mathrm{~N}-07 \mathrm{~W}-26$ BBA 1 & Garfield & 112TRRCH & - & - & 9417 & $1975-$ \\
\hline 362650097555101 & $23 \mathrm{~N}-07 \mathrm{~W}-27$ ABA 1 & Garfield & 112TRRCH & - & 70.0 & 9418 & $1950-$ \\
\hline 362650097562301 & $23 \mathrm{~N}-07 \mathrm{~W}-27$ BBA 1 & Garfield & 112TRRCH & - & - & 9419 & $1975-$ \\
\hline 362637097563101 & $23 \mathrm{~N}-07 \mathrm{~W}-27$ BCB 2 & Garfield & 112TRRCH & - & 60.0 & 9415 & $1950-$ \\
\hline 362650097565501 & $23 \mathrm{~N}-07 \mathrm{~W}-28$ ABA 1 & Garfield & 112TRRCH & - & - & 9420 & $1975-$ \\
\hline 362655097572101 & $23 \mathrm{~N}-07 \mathrm{~W}-28$ BAB 2 & Garfield & 112TRRCH & - & 66.8 & 9421 & $1975-$ \\
\hline 345054096580501 & $04 \mathrm{~N}-03 \mathrm{E}-03 \mathrm{ADD} 1$ & Garvin & - & - & - & 9425 & $1975-$ \\
\hline 344844096575701 & $04 \mathrm{~N}-03 \mathrm{E}-14 \mathrm{CCC} 1$ & Garvin & - & - & - & 9424 & $1975-$ \\
\hline 344222098030101 & $03 \mathrm{~N}-08 \mathrm{~W}-28 \mathrm{BCA} 1$ & Grady & - & - & - & 4686 & $1979-$ \\
\hline 345409097445101 & $05 \mathrm{~N}-05 \mathrm{~W}-17 \mathrm{DCB} 1$ & Grady & - & - & 65.0 & 9429 & $1983-$ \\
\hline 345304097421301 & $05 \mathrm{~N}-05 \mathrm{~W}-26 \mathrm{BBB} 1$ & Grady & - & - & - & 9428 & $1983-$ \\
\hline 351907097510401 & $10 \mathrm{~N}-06 \mathrm{~W}-29$ AAB 1 & Grady & - & - & - & 9430 & $1979-$ \\
\hline 364133097460901 & $26 \mathrm{~N}-05 \mathrm{~W}-31$ ADA 1 & Grant & 112TRRCH & - & 51.0 & 9431 & $1975-$ \\
\hline 364244097471401 & $26 \mathrm{~N}-06 \mathrm{~W}-24$ DDD 1 & Grant & 112TRRCH & - & 53.0 & 9433 & $1975-$ \\
\hline 364514097592101 & $26 \mathrm{~N}-07 \mathrm{~W}-07$ ABA 1 & Grant & 112TRRCH & - & 48.0 & 9434 & $1975-$ \\
\hline 364238098025201 & $26 \mathrm{~N}-08 \mathrm{~W}-27 \mathrm{BAA} 1$ & Grant & 112TRRCH & - & 26.0 & 9432 & 1975 \\
\hline 364935097594601 & $27 \mathrm{~N}-07 \mathrm{~W}-18$ BAB 1 & Grant & 112TRRCH & - & 67.0 & 9435 & $1975-$ \\
\hline 344630099370201 & $04 \mathrm{~N}-23 \mathrm{~W}-33 \mathrm{DAB} 1$ & Greer & 313VVCR & 16 & 155 & 9436 & $1949-$ \\
\hline 345541099193001 & $05 \mathrm{~N}-20 \mathrm{~W}-08$ AAA 1 & Greer & 112TRRCH & - & 57.0 & 9445 & $1980-$ \\
\hline 345403099202501 & $05 \mathrm{~N}-20 \mathrm{~W}-17 \mathrm{CCC} 1$ & Greer & 112TRRCH & - & 58.0 & 9440 & $1980-$ \\
\hline 345356099212801 & $05 \mathrm{~N}-20 \mathrm{~W}-19 \mathrm{BBB} 1$ & Greer & 112TRRCH & - & 49.0 & 9438 & $1980-$ \\
\hline 345528099255801 & $05 \mathrm{~N}-21 \mathrm{~W}-08$ ADB 1 & Greer & 112TRRCH & - & 52.0 & 9444 & $1980-$ \\
\hline 345514099240701 & $05 \mathrm{~N}-21 \mathrm{~W}-10 \mathrm{DBB} 1$ & Greer & 313BLIN & - & 66.0 & 9443 & $1983-$ \\
\hline 345409099220801 & $05 \mathrm{~N}-21 \mathrm{~W}-13 \mathrm{CDA} 1$ & Greer & 112TRRCH & - & 50.0 & 9441 & $1980-$ \\
\hline 345356099224001 & $05 \mathrm{~N}-21 \mathrm{~W}-23$ AAA 1 & Greer & 112TRRCH & - & 50.0 & 9439 & $1980-$ \\
\hline 345547099302701 & $05 \mathrm{~N}-22 \mathrm{~W}-03 \mathrm{DCC} 1$ & Greer & 110ALVM & - & 28.0 & 9446 & $1980-$ \\
\hline 345554099313001 & $05 \mathrm{~N}-22 \mathrm{~W}-04 \mathrm{DCB} 1$ & Greer & 110ALVM & - & 24.0 & 9447 & $1980-$ \\
\hline 345554099281201 & $05 \mathrm{~N}-22 \mathrm{~W}-12$ DCD 1 & Greer & 110EFRT & - & 46 & 9442 & $1980-$ \\
\hline 345251099363101 & $05 \mathrm{~N}-23 \mathrm{~W}-27$ ACA 1 & Greer & 313BLIN & 16 & 109 & 9437 & $1956-$ \\
\hline 350055099204901 & $06 \mathrm{~N}-20 \mathrm{~W}-07$ ABA 1 & Greer & 112TRRCH & - & 52.0 & 9450 & $1980-$ \\
\hline 350121099232701 & $06 \mathrm{~N}-21 \mathrm{~W}-02 \mathrm{CBA} 1$ & Greer & 112TRRCH & - & 75.0 & 9451 & $1980-$ \\
\hline 345758099345601 & $06 \mathrm{~N}-23 \mathrm{~W}-25 \mathrm{BDC} 1$ & Greer & $110 \mathrm{ALVM}$ & - & 47.0 & 9448 & $1980-$ \\
\hline 345818099413701 & $06 \mathrm{~N}-24 \mathrm{~W}-25 \mathrm{BBB} 1$ & Greer & - & - & 24.0 & 9449 & $1980-$ \\
\hline 350615099242301 & $07 \mathrm{~N}-21 \mathrm{~W}-03 \mathrm{CDC} 1$ & Greer & $110 \mathrm{ALVM}$ & - & 49.0 & 9460 & $1980-$ \\
\hline 350641099274901 & $07 \mathrm{~N}-21 \mathrm{~W}-06 \mathrm{BCC} 1$ & Greer & 112TRRCH & - & - & 9461 & $1980-$ \\
\hline 350529099255801 & $07 \mathrm{~N}-21 \mathrm{~W}-08 \mathrm{DDB} 1$ & Greer & 112TRRCH & - & 70.0 & 9459 & $1980-$ \\
\hline 350516099243901 & $07 \mathrm{~N}-21 \mathrm{~W}-15 \mathrm{BBB} 1$ & Greer & 112TRRCH & - & - & 9456 & $1980-$ \\
\hline 350457099254201 & $07 \mathrm{~N}-21 \mathrm{~W}-16 \mathrm{CCB} 1$ & Greer & - & - & 71.0 & 9454 & $1980-$ \\
\hline 350457099271701 & $07 \mathrm{~N}-21 \mathrm{~W}-18$ ACC 1 & Greer & 313BLIN & - & 102 & 9455 & $1980-$ \\
\hline
\end{tabular}


Table 1.-Ground-water sites included in the mass measurement network-Continued

\begin{tabular}{|c|c|c|c|c|c|c|c|c|}
\hline Site-ID & Local well number & & County & $\begin{array}{c}\text { Aquifer } \\
\text { code }\end{array}$ & $\begin{array}{c}\text { Diameter } \\
\text { of } \\
\text { casing } \\
\text { (in.) } \\
\end{array}$ & $\begin{array}{c}\text { Depth } \\
\text { of well } \\
(\mathrm{ft})\end{array}$ & $\begin{array}{c}\text { OWRB } \\
\text { identifier }\end{array}$ & $\begin{array}{c}\text { Period } \\
\text { of } \\
\text { record }\end{array}$ \\
\hline 350411099274101 & $07 N-21 W-19$ BCA & 1 & Greer & 112TRRCH & - & 67.0 & 9453 & $1981-$ \\
\hline 350239099265301 & $07 \mathrm{~N}-21 \mathrm{~W}-31$ AAA & 1 & Greer & 112TRRCH & - & 68.0 & 9452 & $1980-$ \\
\hline 350701099302701 & $07 \mathrm{~N}-22 \mathrm{~W}-03 \mathrm{ABB}$ & 1 & Greer & 112TRRCH & - & 113 & 9462 & $1980-$ \\
\hline 350516099282801 & $07 \mathrm{~N}-22 \mathrm{~W}-13 \mathrm{BAA}$ & 1 & Greer & 112TRRCH & - & 78.0 & 9457 & $1980-$ \\
\hline 343020099422001 & $01 \mathrm{~N}-24 \mathrm{~W}-34 \mathrm{DCC}$ & 1 & Harmon & 313VVCR & 16 & 94 & 9463 & $1956-$ \\
\hline 343419099462201 & $01 N-25 W-12$ DABA & & Harmon & 313BLIN & - & 212 & 9465 & $1976-$ \\
\hline 343042099474701 & $01 \mathrm{~N}-25 \mathrm{~W}-35 \mathrm{DDBA}$ & & Harmon & 313VVCR & 16 & 72 & 9464 & $1976-$ \\
\hline 343820099593001 & 02N-17W-16 DCC & 1 & Harmon & - & - & 55.5 & 9533 & $1989-$ \\
\hline 343814099481501 & $02 \mathrm{~N}-25 \mathrm{~W}-23 \mathrm{ABB}$ & 1 & Harmon & 313DGCK & 12 & 130 & 9467 & $1956-$ \\
\hline 343512099574701 & $02 \mathrm{~N}-26 \mathrm{~W}-05 \mathrm{BCCC}$ & & Harmon & 313BLIN & 16 & 149 & 9470 & $1950-$ \\
\hline 343855099544501 & 02N-26W-15 AADD & & Harmon & 313BLIN & 16 & 130 & 9468 & $1956-$ \\
\hline 343559099534901 & $02 \mathrm{~N}-26 \mathrm{~W}-31 \mathrm{CBCD}$ & & Harmon & 313BLIN & 16 & 150 & 9466 & $1950-$ \\
\hline 344015099594501 & $02 \mathrm{~N}-27 \mathrm{~W}-01 \mathrm{CCBB}$ & 1 & Harmon & 313BLIN & 16 & 150 & 9469 & $1952-$ \\
\hline 344220099441601 & $03 \mathrm{~N}-24 \mathrm{~W}-29$ AAA & 2 & Harmon & 313BLIN & - & 169 & 9472 & $1954-$ \\
\hline 344145099512501 & $03 N-25 W-32$ BBBD & 1 & Harmon & 313BLIN & 16 & 160 & 9471 & $1956-$ \\
\hline 363749099364301 & $25 \mathrm{~N}-22 \mathrm{~W}-19 \mathrm{BDD}$ & 1 & Harper & 110ALVM & 6 & 130 & 9476 & $1978-$ \\
\hline 363844099442301 & $25 \mathrm{~N}-24 \mathrm{~W}-13 \mathrm{BDC}$ & 1 & Harper & 110ALVM & 6 & 52.0 & 9478 & $1978-$ \\
\hline 363827099485001 & $25 \mathrm{~N}-24 \mathrm{~W}-17 \mathrm{CC}$ & 1 & Harper & 112TRRCH & 18 & 40.0 & 9477 & $1977-$ \\
\hline 363957099540201 & $25 \mathrm{~N}-25 \mathrm{~W}-09 \mathrm{BAA}$ & 1 & Harper & 110ALVM & - & - & 9480 & $1977-$ \\
\hline 363602099550601 & $25 N-25 W-32$ BDD & 1 & Harper & 110ALVM & 16 & 175 & 9474 & $1981-$ \\
\hline 363714099564301 & $25 \mathrm{~N}-26 \mathrm{~W}-25 \mathrm{AAD}$ & 1 & Harper & 121OGLL & 5 & 135 & 9475 & $1975-$ \\
\hline 363538099575301 & $25 \mathrm{~N}-26 \mathrm{~W}-35 \mathrm{DDD}$ & 1 & Harper & 121OGLL & - & 270 & 9473 & $1980-$ \\
\hline 364118099444701 & $26 \mathrm{~N}-24 \mathrm{~W}-35$ ADD & 1 & Harper & 110ALVM & 4 & 27.0 & 9482 & $1978-$ \\
\hline 364336099542001 & $26 \mathrm{~N}-25 \mathrm{~W}-17 \mathrm{DC}$ & 1 & Harper & 112TRRCH & 16 & - & 9484 & $1972-$ \\
\hline 364102099554601 & $26 \mathrm{~N}-25 \mathrm{~W}-31 \mathrm{DDA}$ & 1 & Harper & 112TRRCH & 4 & 46.0 & 9481 & $1978-$ \\
\hline 364255099581301 & $26 \mathrm{~N}-26 \mathrm{~W}-23 \mathrm{DBC}$ & 1 & Harper & 121OGLL & - & 110 & 9483 & $1980-$ \\
\hline 364825099494701 & $27 \mathrm{~N}-24 \mathrm{~W}-19 \mathrm{BDB}$ & 1 & Harper & 110ALVM & 4 & 119 & 9485 & $1978-$ \\
\hline 364842099554001 & $27 \mathrm{~N}-25 \mathrm{~W}-19$ AAA & 1 & Harper & 121OGLL & - & 50.0 & 9486 & $1979-$ \\
\hline 364953099564001 & $27 \mathrm{~N}-26 \mathrm{~W}-12 \mathrm{DAD}$ & 1 & Harper & 121OGLL & - & 85 & 9488 & $1980-$ \\
\hline 364923099570301 & $27 N-26 W-13$ ABD & 1 & Harper & 110ALVM & 6 & 33.0 & 9487 & $1978-$ \\
\hline 344929096053501 & $04 \mathrm{~N}-11 \mathrm{E}-13 \mathrm{AAA}$ & 1 & Hughes & 325 TRMN & - & -- & 9490 & $1976-$ \\
\hline 350945096240401 & $08 \mathrm{~N}-09 \mathrm{E}-18 \mathrm{CDA}$ & 1 & Hughes & - & 3 & 29.7 & 9491 & $1982-$ \\
\hline 351029096162701 & $08 \mathrm{~N}-19 \mathrm{E}-11 \mathrm{CDC}$ & 1 & Hughes & 325BGGY & - & 66.0 & 9489 & $1978-$ \\
\hline 351538096113401 & $09 \mathrm{~N}-11 \mathrm{E}-18 \mathrm{BBB}$ & 1 & Hughes & - & 3 & 15.0 & 9493 & $1982-$ \\
\hline 343020099404501 & $01 \mathrm{~S}-24 \mathrm{~W}-02 \mathrm{ABB}$ & 1 & Jackson & 313BLIN & 6 & 55.5 & 9495 & $1957-$ \\
\hline 342744099460701 & $01 \mathrm{~S}-25 \mathrm{~W}-13 \mathrm{CCCA}$ & 1 & Jackson & 313BLIN & 16 & 130 & 9494 & $1953-$ \\
\hline 343913099313901 & $02 \mathrm{~N}-22 \mathrm{~W}-08 \mathrm{DDA}$ & 1 & Jackson & 313BLIN & - & 75 & 9497 & $1953-$ \\
\hline 343945099342501 & $02 \mathrm{~N}-23 \mathrm{~W}-12 \mathrm{BBDD}$ & 1 & Jackson & 313BLIN & 16 & 200 & 9498 & 1948 \\
\hline 343810099365701 & $02 \mathrm{~N}-23 \mathrm{~W}-21 \mathrm{AAA}$ & 1 & Jackson & 313BLIN & - & 89 & 9496 & $1953-$ \\
\hline 344114099323701 & $03 \mathrm{~N}-22 \mathrm{~W}-32 \mathrm{CBB}$ & 2 & Jackson & 313BLIN & 14 & 182 & 9500 & $1949-$ \\
\hline
\end{tabular}


Table 1.-Ground-water sites included in the mass measurement network-Continued

\begin{tabular}{|c|c|c|c|c|c|c|c|c|}
\hline Site-ID & Local well number & & County & $\begin{array}{l}\text { Aquifer } \\
\text { code }\end{array}$ & $\begin{array}{l}\text { Diameter } \\
\text { of } \\
\text { casing } \\
\text { (in.) }\end{array}$ & $\begin{array}{l}\text { Depth } \\
\text { of well } \\
\text { (ft) }\end{array}$ & $\begin{array}{c}\text { OWRB } \\
\text { identifier }\end{array}$ & $\begin{array}{l}\text { Period } \\
\text { of } \\
\text { record }\end{array}$ \\
\hline 344220099355501 & $03 \mathrm{~N}-23 \mathrm{~W}-27$ ADAA & & Jackson & 313BLIN & 16 & 127 & 9501 & $1948-$ \\
\hline 344032098390201 & $03 \mathrm{~N}-23 \mathrm{~W}-30 \mathrm{DAA}$ & 1 & Jackson & 313BLIN & 16 & 90 & 9499 & $1952-$ \\
\hline 344637099152801 & $04 \mathrm{~N}-20 \mathrm{~W}-36 \mathrm{BDC}$ & 1 & Jackson & 110ALVM & - & 97.0 & 9502 & $1977-$ \\
\hline 340827097593301 & 05S-08W-12 BAD & 1 & Jefferson & - & - & - & 9503 & $1979-$ \\
\hline 342236096262701 & 02S- 08E-14 CCC & 1 & Johnston & - & - & - & 9505 & $1979-$ \\
\hline 341243096534501 & $04 \mathrm{~S}-04 \mathrm{E}-16 \mathrm{BBC}$ & 1 & Johnston & 218ALRS & - & - & 9504 & $1977-$ \\
\hline 364001097200001 & $25 \mathrm{~N}-01 \mathrm{~W}-08 \mathrm{BBA}$ & 1 & Kay & - & - & - & 9506 & $1976-$ \\
\hline 364222097025601 & $26 \mathrm{~N}-02 \mathrm{E}-25 \mathrm{BBC}$ & 1 & Kay & - & - & - & 9508 & $1975-$ \\
\hline 364210097025401 & $26 \mathrm{~N}-02 \mathrm{E}-26 \mathrm{BDD}$ & 1 & Kay & 110ALVM & - & 38.0 & 9507 & $1977-$ \\
\hline 365824097272901 & $29 \mathrm{~N}-02 \mathrm{~W}-19 \mathrm{CDC}$ & 1 & Kay & - & - & - & 9509 & $1975-$ \\
\hline 355724097430301 & $17 \mathrm{~N}-05 \mathrm{~W}-10 \mathrm{DCC}$ & 1 & Kingfisher & $110 \mathrm{CMTA}$ & - & 45 & 9512 & $1974-$ \\
\hline 355632097464801 & $17 \mathrm{~N}-05 \mathrm{~W}-18 \mathrm{CCC}$ & 1 & Kingfisher & 110CMTA & - & 30 & 9510 & $1974-$ \\
\hline 355724097480001 & $17 \mathrm{~N}-06 \mathrm{~W}-11 \mathrm{DDD}$ & 1 & Kingfisher & $110 \mathrm{CMTA}$ & - & 60 & 9513 & 1974-- \\
\hline 355810097465601 & $17 \mathrm{~N}-06 \mathrm{~W}-12$ AAA & 1 & Kingfisher & 110CMTA & - & 80 & 9517 & $1974-$ \\
\hline 355658097531201 & $17 \mathrm{~N}-06 \mathrm{~W}-18 \mathrm{BCC}$ & 1 & Kingfisher & $110 \mathrm{CMTA}$ & - & 30 & 9511 & $1974-$ \\
\hline 355743097544001 & $17 \mathrm{~N}-07 \mathrm{~W}-11 \mathrm{DBA}$ & 1 & Kingfisher & 110CMTA & 4.5 & 40 & 9516 & $1973-$ \\
\hline 355724097544001 & $17 \mathrm{~N}-07 \mathrm{~W}-11 \mathrm{DCD}$ & 2 & Kingfisher & $110 \mathrm{CMTA}$ & 4.5 & 33 & 9514 & $1974-$ \\
\hline 355743097532001 & $17 \mathrm{~N}-07 \mathrm{~W}-12 \mathrm{DAA}$ & 1 & Kingfisher & 110CMTA & - & 30 & 9515 & $1975-$ \\
\hline 355823097020901 & $17 \mathrm{~N}-08 \mathrm{~W}-03 \mathrm{DCA}$ & 1 & Kingfisher & $112 \mathrm{TRRCH}$ & - & - & 9518 & $1981-$ \\
\hline 360342097495201 & $18 \mathrm{~N}-06 \mathrm{~W}-03 \mathrm{CBD}$ & 1 & Kingfisher & $110 \mathrm{CMTA}$ & - & 45 & 9527 & $1974-$ \\
\hline 360316097522401 & $18 \mathrm{~N}-06 \mathrm{~W}-07$ AAC & 1 & Kingfisher & 110CMTA & - & 34 & 9526 & 1974- \\
\hline 360230097512001 & $18 \mathrm{~N}-06 \mathrm{~W}-17 \mathrm{AAB}$ & 1 & Kingfisher & $110 \mathrm{CMTA}$ & - & 58 & 9524 & $1974-$ \\
\hline 355954097524801 & $18 \mathrm{~N}-06 \mathrm{~W}-31 \mathrm{BAA}$ & 1 & Kingfisher & $110 \mathrm{CMTA}$ & - & 56 & 9521 & $1974-$ \\
\hline 355908097521601 & $18 \mathrm{~N}-06 \mathrm{~W}-31 \mathrm{DDD}$ & 2 & Kingfisher & 110CMTA & - & 36 & 9519 & $1974-$ \\
\hline 355954097514401 & $18 \mathrm{~N}-06 \mathrm{~W}-32 \mathrm{BAA}$ & 1 & Kingfisher & $110 \mathrm{CMTA}$ & - & 70 & 9520 & 1974- \\
\hline 360052097564801 & $18 \mathrm{~N}-07 \mathrm{~W}-21 \mathrm{DCD}$ & 1 & Kingfisher & $110 \mathrm{CMTA}$ & 5 & 63 & 9522 & $1950-$ \\
\hline 360230098004101 & $18 \mathrm{~N}-08 \mathrm{~W}-13 \mathrm{BBB}$ & 1 & Kingfisher & 110CMTA & - & - & 9525 & $1975-$ \\
\hline 361045097590501 & 19N-07W-30 DCD & 1 & Kingfisher & 110CMTA & 16 & 92 & 9528 & $1950-$ \\
\hline 360922098021401 & $19 \mathrm{~N}-08 \mathrm{~W}-03 \mathrm{AAB}$ & 1 & Kingfisher & 110CMTA & 5 & 48 & 9532 & $1950-$ \\
\hline 360657098041701 & $19 \mathrm{~N}-08 \mathrm{~W}-17$ DCD & 1 & Kingfisher & $110 \mathrm{CMTA}$ & - & 74 & 9530 & $1974-$ \\
\hline 360526098020101 & $19 \mathrm{~N}-08 \mathrm{~W}-27 \mathrm{DAC}$ & 1 & Kingfisher & 110CMTA & 16 & 67 & 9529 & $1950-$ \\
\hline 360750098084901 & $19 \mathrm{~N}-09 \mathrm{~W}-10 \mathrm{CDD}$ & 1 & Kingfisher & 110CMTA & - & 32 & 9531 & $1974-$ \\
\hline 344005098591001 & $02 \mathrm{~N}-17 \mathrm{~W}-04 \mathrm{DDC}$ & 1 & Kiowa & 112TRRCH & - & 44.0 & 9538 & $1981-$ \\
\hline 343913098592601 & $02 \mathrm{~N}-17 \mathrm{~W}-09 \mathrm{DCC}$ & 1 & Kiowa & 112TRRCH & - & 49.0 & 9537 & $1981-$ \\
\hline 343913098564801 & $02 \mathrm{~N}-17 \mathrm{~W}-12 \mathrm{CCC}$ & 1 & Kiowa & 112TRRCH & - & 48.0 & 9536 & $1978-$ \\
\hline 343903098580001 & $02 \mathrm{~N}-17 \mathrm{~W}-15$ AAA & 1 & Kiowa & 112TRRCH & - & 45.0 & 9535 & $1985-$ \\
\hline 343846099000501 & $02 \mathrm{~N}-17 \mathrm{~W}-17$ ADD & 1 & Kiowa & 112TRRCH & - & 40.0 & 9534 & 1979- \\
\hline 344235098541801 & $03 \mathrm{~N}-16 \mathrm{~W}-29 \mathrm{BAA}$ & 1 & Kiowa & 112TRRCH & - & 35.0 & 9541 & $1978-$ \\
\hline 344149098582301 & $03 \mathrm{~N}-17 \mathrm{~W}-27$ DCC & 1 & Kiowa & 112TRRCH & - & 60.0 & 9539 & $1978^{-}$ \\
\hline 344210098593501 & $03 \mathrm{~N}-17 \mathrm{~W}-28 \mathrm{CA}$ & 1 & Kiowa & 112TRRCH & - & 40.0 & 9540 & $1976-$ \\
\hline
\end{tabular}


Table 1.-Ground-water sites included in the mass measurement network-Continued

\begin{tabular}{|c|c|c|c|c|c|c|c|}
\hline Site-ID & Local well number & County & $\begin{array}{c}\text { Aquifer } \\
\text { code }\end{array}$ & $\begin{array}{c}\text { Diameter } \\
\text { of } \\
\text { casing } \\
\text { (in.) }\end{array}$ & $\begin{array}{l}\text { Depth } \\
\text { of well } \\
\text { (ft) }\end{array}$ & $\begin{array}{c}\text { OWRB } \\
\text { identifier }\end{array}$ & $\begin{array}{c}\text { Period } \\
\text { of } \\
\text { record }\end{array}$ \\
\hline 344821099082201 & $04 \mathrm{~N}-18 \mathrm{~W}-19$ BCC 1 & Kiowa & 112TRRCH & - & 23.0 & 9544 & $1979-$ \\
\hline 344745099083001 & $04 \mathrm{~N}-19 \mathrm{~W}-25$ AAA 1 & Kiowa & $110 \mathrm{ALVM}$ & - & 33.0 & 9543 & $1978-$ \\
\hline 344637099085401 & $04 \mathrm{~N}-19 \mathrm{~W}-36$ ACC 1 & Kiowa & 112TRRCH & - & 19.0 & 9542 & 1981- \\
\hline 345857099193001 & $06 \mathrm{~N}-20 \mathrm{~W}-20$ ADA 2 & Kiowa & $112 \mathrm{TRRCH}$ & - & 68.0 & 9553 & $1976-$ \\
\hline 345844099193001 & $06 \mathrm{~N}-20 \mathrm{~W}-20$ DAA 1 & Kiowa & 112TRRCH & - & 64.0 & 9552 & $1976-$ \\
\hline 345831099191401 & $06 \mathrm{~N}-20 \mathrm{~W}-21 \mathrm{CCA} 1$ & Kiowa & 112TRRCH & - & 66.0 & 9551 & $1976-$ \\
\hline 345824099185001 & $06 \mathrm{~N}-20 \mathrm{~W}-21$ DCC 2 & Kiowa & 112TRRCH & - & 42.0 & 9550 & $1976-$ \\
\hline 345824099165901 & $06 \mathrm{~N}-20 \mathrm{~W}-23 \mathrm{CDC} 1$ & Kiowa & 112TRRCH & - & 38.0 & 9549 & $1976-$ \\
\hline 345732099181801 & $06 \mathrm{~N}-20 \mathrm{~W}-27 \mathrm{CCC} 1$ & Kiowa & 112TRRCH & - & 38.0 & 9546 & $1976-$ \\
\hline 345751099185801 & $06 \mathrm{~N}-20 \mathrm{~W}-28 \mathrm{CAA} 1$ & Kiowa & 112TRRCH & - & 57.0 & 9547 & $1979-$ \\
\hline 345818099193001 & $061^{\circ}-20 \mathrm{~W}-29$ AAA 1 & Kiowa & 112TRRCH & - & 51.0 & 9548 & $1979-$ \\
\hline 345659099162001 & $06 \mathrm{~N}-20 \mathrm{~W}-35$ DAA 1 & Kiowa & 112TRRCH & - & - & 9545 & $1976-$ \\
\hline 350457098453401 & $07 \mathrm{~N}-15 \mathrm{~W}-14 \mathrm{BCC} 1$ & Kiowa & 112TRRCH & - & 46 & 9555 & $1956-$ \\
\hline 350226099074501 & $07 \mathrm{~N}-18 \mathrm{~W}-32$ BCB 1 & Kiowa & 313DGCK & - & - & 9554 & $1976-$ \\
\hline 345509095184901 & $05 \mathrm{~N}-19 \mathrm{E}-09 \mathrm{CBB} 1$ & Latimer & - & - & - & 9556 & $1976-$ \\
\hline 345021094320801 & $04 \mathrm{~N}-26 \mathrm{E}-11$ AAA 1 & Le Flore & - & - & - & 9557 & $1980-$ \\
\hline 352907096411001 & $12 \mathrm{~N}-06 \mathrm{E}-29 \mathrm{DAB} 1$ & Lincoln & - & - & - & 9558 & $1980-$ \\
\hline 354205096530801 & $14 \mathrm{~N}-04 \mathrm{E}-09 \mathrm{CAB} 1$ & Lincoln & - & - & - & 9559 & $1980-$ \\
\hline 355540097054901 & $17 \mathrm{~N}-02 \mathrm{E}-21 \mathrm{CDD} 1$ & Lincoln & $322 \mathrm{VMOS}$ & - & 80.0 & 9560 & $1977-$ \\
\hline 354328097234801 & $14 \mathrm{~N}-02 \mathrm{~W}-03 \mathrm{ABB} 1$ & Logan & - & - & 110 & 9624 & $1976-$ \\
\hline 355315097390701 & $16 \mathrm{~N}-04 \mathrm{~W}-05 \mathrm{CCA} 1$ & Logan & $110 \mathrm{CMTA}$ & - & 75 & 9561 & $1983-$ \\
\hline 355717097252601 & $17 \mathrm{~N}-02 \mathrm{~W}-16$ BBB 1 & Logan & - & - & 34.0 & 9568 & $1984-$ \\
\hline 355632097365501 & $17 \mathrm{~N}-04 \mathrm{~W}-15 \mathrm{CDC} 1$ & Logan & 110CMTA & - & - & 9567 & 1974- \\
\hline 355606097392701 & $17 \mathrm{~N}-04 \mathrm{~W}-19$ ADD 1 & Logan & $110 \mathrm{CMTA}$ & - & - & 9566 & $1974-$ \\
\hline 355447097365501 & $17 \mathrm{~N}-04 \mathrm{~W}-27 \mathrm{CDC} 1$ & Logan & 110CMTA & - & - & 9565 & $1975-$ \\
\hline 355355097402301 & $17 \mathrm{~N}-04 \mathrm{~W}-31$ CCC 1 & Logan & $110 \mathrm{CMTA}$ & 4 & 52.20 & 9562 & $1974-$ \\
\hline 355441097363901 & $17 \mathrm{~N}-04 \mathrm{~W}-34$ ABB 1 & Logan & 110CMTA & - & - & 9564 & $1974-$ \\
\hline 355402097371101 & $17 \mathrm{~N}-04 \mathrm{~W}-34 \mathrm{CCB} 1$ & Logan & $110 \mathrm{CMTA}$ & - & 57 & 9563 & $1974-$ \\
\hline 335106097244901 & $08 \mathrm{~S}-02 \mathrm{~W}-21$ BAA 1 & Love & 112TRRCH & - & 51.0 & 9569 & $1980-$ \\
\hline 345646097160401 & 06N-01W-35 DDB 1 & McClain & 110ALVM & - & - & 9591 & $1976-$ \\
\hline 351043097294001 & $08 \mathrm{~N}-03 \mathrm{~W}-10$ DDA 1 & McClain & 323 IOLA & - & - & 9.593 & $1976-$ \\
\hline 350957097274901 & $08 \mathrm{~N}-03 \mathrm{~W}-13 \mathrm{CBC} 1$ & McClain & - & - & - & 9592 & $1980-$ \\
\hline 342812094382601 & 01S- $25 \mathrm{E}-14$ DAA 1 & McCurtain & - & - & 300 & 9596 & $1984-$ \\
\hline 340042095051801 & $06 \mathrm{~S}-21 \mathrm{E}-27$ AAA 1 & McCurtain & 218ALRS & - & - & 9595 & $1956-$ \\
\hline 335904094444001 & $06 \mathrm{~S}-24 \mathrm{E}-36 \mathrm{DCD} 1$ & McCurtain & - & - & 62.0 & 9594 & $1984-$ \\
\hline 351206095504201 & $08 \mathrm{~N}-14 \mathrm{E}-05 \mathrm{AAB} 1$ & McIntosh & 112TRRCH & - & - & 9597 & $1981-$ \\
\hline 352420095472601 & $11 \mathrm{~N}-14 \mathrm{E}-26 \mathrm{ABB} 1$ & McIntosh & - & 3 & 32.2 & 9598 & $1982-$ \\
\hline 361442098092801 & $20 \mathrm{~N}-09 \mathrm{~W}-04$ AAA 1 & Major & 110CMTA & 6 & 60 & 9575 & $1965-$ \\
\hline 361355098112101 & $20 \mathrm{~N}-09 \mathrm{~W}-05 \mathrm{CCC} 1$ & Major & 110CMTA & - & 53 & 9574 & $1949-$ \\
\hline 361302098130601 & $20 \mathrm{~N}-10 \mathrm{~W}-12 \mathrm{CDD} 1$ & Major & $110 \mathrm{CMTA}$ & - & 54 & 9573 & $1978-$ \\
\hline
\end{tabular}


Table 1,-Ground-water sites included in the mass measurement network--Continued

\begin{tabular}{|c|c|c|c|c|c|c|c|}
\hline Site-ID & Local well number & County & $\begin{array}{l}\text { Aquifer } \\
\text { code }\end{array}$ & $\begin{array}{l}\text { Diameter } \\
\text { of } \\
\text { casing } \\
\text { (in.) }\end{array}$ & $\begin{array}{c}\text { Depth } \\
\text { of well } \\
\text { (ft) }\end{array}$ & $\begin{array}{c}\text { OWRB } \\
\text { identifier }\end{array}$ & $\begin{array}{l}\text { Period } \\
\text { of } \\
\text { record }\end{array}$ \\
\hline 361155098360801 & $20 \mathrm{~N}-13 \mathrm{~W}-20$ ADA 1 & Major & 112TRRCH & 5 & 61.0 & 9571 & $1978-$ \\
\hline 361117098543101 & $20 N-16 \mathrm{~W}-21$ DCD 1 & Major & 110TRRCL & 6 & 41.0 & 9570 & $1978-$ \\
\hline 361907098123501 & $21 \mathrm{~N}-09 \mathrm{~W}-06 \mathrm{CCC} 1$ & Major & 110CMTA & - & 40.0 & 9580 & $1976-$ \\
\hline 361631098103501 & $21 \mathrm{~N}-09 \mathrm{~W}-20 \mathrm{DDD} 1$ & Major & 110CMTA & 24 & 49.5 & 9577 & $1950-$ \\
\hline 361624098120301 & $21 \mathrm{~N}-09 \mathrm{~W}-30 \mathrm{AB} \quad 1$ & Major & 110CMTA & 1.25 & 21 & 9576 & $1950-$ \\
\hline 361723098164401 & $21 \mathrm{~N}-10 \mathrm{~W}-16 \mathrm{CC} \quad 1$ & Major & 110CMTA & 10 & 39 & 9579 & $1951-$ \\
\hline 361631098155601 & $21 \mathrm{~N}-10 \mathrm{~W}-21$ DDD 1 & Major & 110CMTA & 24 & 40 & 9578 & $1950-$ \\
\hline 362045098183101 & $22 \mathrm{~N}-10 \mathrm{~W}-31$ BAA 1 & Major & 110CMTA & - & 51 & 9581 & $1974-$ \\
\hline 362506098210101 & $22 \mathrm{~N}-11 \mathrm{~W}-02$ BBA 1 & Major & 110CMTA & 一 & 75 & 9585 & $1983-$ \\
\hline 362427098211701 & $22 \mathrm{~N}-11 \mathrm{~W}-03$ DDA 1 & Major & 110CMTA & - & - & 9584 & 1983- \\
\hline 362210098201301 & $22 \mathrm{~N}-11 \mathrm{~W}-23$ ADD 1 & Major & 110CMTA & - & 75 & 9583 & $1974-$ \\
\hline 362716098243001 & $23 \mathrm{~N}-11 \mathrm{~W}-19$ DAA 1 & Major & 110CMTA & - & 55 & 9587 & $1974-$ \\
\hline 362650098191701 & $23 \mathrm{~N}-11 \mathrm{~W}-25$ AAB 1 & Major & 110CMTA & 一 & - & 9586 & $1983-$ \\
\hline 335621096380301 & 07S- 06E-24 BBA 1 & 095 & - & - & - & 9588 & $1978-$ \\
\hline 361132095130901 & $20 N-20 E-19$ CCD 1 & Mayes & - & 一 & - & 9589 & $1979-$ \\
\hline 361547095151901 & $21 \mathrm{~N}-19 \mathrm{E}-35 \mathrm{BAB} 1$ & Mayes & - & - & - & 9590 & $1977-$ \\
\hline 343208096494101 & $01 \mathrm{~N}-04 \mathrm{E}-25$ AAA 1 & Murray & - & 一 & - & 9599 & $1976-$ \\
\hline 352143095131301 & $10 \mathrm{~N}-20 \mathrm{E}-07$ AAA 1 & Muskogee & 110ALVM & 一 & - & 9600 & $1981-$ \\
\hline 365439095270101 & $28 \mathrm{~N}-17 \mathrm{E}-14$ ADD 1 & Nowata & 121OGLL & - & - & 9602 & $1979-$ \\
\hline 365321095282901 & $28 \mathrm{~N}-17 \mathrm{E}-22$ DCC 1 & Nowata & 121OGLL & 一 & - & 9601 & 1979 \\
\hline 365903095390001 & $29 \mathrm{~N}-15 \mathrm{E}-23$ ABB 1 & Nowata & - & - & - & 9603 & $1979-$ \\
\hline 352213096210801 & $10 \mathrm{~N}-09 \mathrm{E}-15 \mathrm{BBB} 1$ & Okfuskee & - & 3 & 20.8 & 9605 & $1982-$ \\
\hline 352000096110401 & $10 \mathrm{~N}-11 \mathrm{E}-18 \mathrm{DCC} 1$ & Okfuskee & - & 3 & 24.7 & 9604 & $1982-$ \\
\hline 352752096344701 & $11 N-07 E-33$ CCD 1 & Okfuskee & - & 3 & 37.2 & 9607 & $1982-$ \\
\hline 352659096252301 & $11 \mathrm{~N}-08 \mathrm{E}-12 \mathrm{BBB} 1$ & Okfuskee & - & 3 & 20.0 & 9606 & $1982-$ \\
\hline 352637097253701 & $11 \mathrm{~N}-02 \mathrm{~W}-08$ ADC 1 & Oklahoma & 318GRBR & - & 743 & 9608 & $1975-$ \\
\hline 352726097294301 & $11 N-03 W-03$ ADD 1 & Oklahoma & - & 3 & 19.5 & 9610 & $1982-$ \\
\hline 352700097384101 & $11 \mathrm{~N}-04 \mathrm{~W}-05 \mathrm{CDD} 1$ & Oklahoma & - & 3 & 17.5 & 9609 & $1982-$ \\
\hline 352940097225001 & $12 N-02 W-23$ CDD 1 & Oklahoma & - & - & 180 & 9611 & $1979-$ \\
\hline 353236097332601 & $12 \mathrm{~N}-03 \mathrm{~W}-06 \mathrm{CAA} 1$ & Oklahoma & - & - & 762 & 9612 & $1976-$ \\
\hline 353749097243601 & $13 \mathrm{~N}-02 \mathrm{~W}-04$ DAB 1 & Oklahoma & - & - & 130 & 9618 & $1981-$ \\
\hline 353729097253201 & $13 \mathrm{~N}-02 \mathrm{~W}-05 \mathrm{DDD} 1$ & Oklahoma & 318GRBR & 一 & 260.00 & 9617 & $1986-$ \\
\hline 353354097301201 & $13 N-03 W-34$ ABB 1 & Oklahoma & 318GRBR & - & 200 & 9614 & $1984-$ \\
\hline 354231097140501 & $14 \mathrm{~N}-01 \mathrm{E}-07$ ABA 1 & Oklahoma & 318GRBR & 6 & 87.0 & 9622 & $1974-$ \\
\hline 353948097112501 & $14 \mathrm{~N}-01 \mathrm{E}-27 \mathrm{BAB} 1$ & Oklahoma & 310WLNG & 8 & 200 & 9620 & 1973- \\
\hline 354025097200501 & $14 \mathrm{~N}-01 \mathrm{~W}-20 \mathrm{CBB} 1$ & Oklahoma & - & - & 43.0 & 9621 & $1956-$ \\
\hline 354243097300401 & $14 N-03 W-03$ DCD 1 & Oklahoma & - & - & 410 & 9623 & $1976-$ \\
\hline 353914097325901 & $14 N-03 W-30$ DDD 1 & Oklahoma & - & 6 & 134 & 9619 & $1973-$ \\
\hline 354302096102101 & $14 \mathrm{~N}-11 \mathrm{E}-06$ DAA 1 & Okmulgee & 323CFVL & 一 & - & 9625 & $1981-$ \\
\hline 361526096084201 & $21 \mathrm{~N}-11 \mathrm{E}-32 \mathrm{ABC} 1$ & Osage & 323IOLA & 一 & - & 9626 & $1979-$ \\
\hline
\end{tabular}


Table 1.-Ground-water sites included in the mass measurement network-Continued

\begin{tabular}{|c|c|c|c|c|c|c|c|}
\hline Site-ID & Local well number & County & $\begin{array}{l}\text { Aquifer } \\
\text { code }\end{array}$ & $\begin{array}{l}\text { Diameter } \\
\text { of } \\
\text { casing } \\
\text { (in.) }\end{array}$ & $\begin{array}{c}\text { Depth } \\
\text { of well } \\
\text { (ft) }\end{array}$ & $\begin{array}{l}\text { OWRB } \\
\text { identifier }\end{array}$ & $\begin{array}{c}\text { Period } \\
\text { of } \\
\text { record }\end{array}$ \\
\hline 365745094580101 & $29 \mathrm{~N}-22 \mathrm{E}-30$ AAC 1 & Ottawa & $331 \mathrm{BOON}$ & - & - & 9627 & $1979-$ \\
\hline 361631096301901 & $21 \mathrm{~N}-07 \mathrm{E}-24 \mathrm{CDD} 1$ & Pawnee & 323IOLA & - & 一 & 9628 & $1979-$ \\
\hline 363058096440101 & $24 \mathrm{~N}-05 \mathrm{E}-35$ ACA 1 & Pawnee & 112TRRCH & - & - & 9629 & $1978-$ \\
\hline 355810097134101 & $17 \mathrm{~N}-01 \mathrm{E}-08 \mathrm{BBB} 1$ & Payne & - & - & 65.0 & 9630 & $1983-$ \\
\hline 355908097030101 & $18 \mathrm{~N}-02 \mathrm{E}-36 \mathrm{CCC} 1$ & Payne & 112TRRCH & - & - & 9633 & $1979-$ \\
\hline 355908096554101 & $18 \mathrm{~N}-03 \mathrm{E}-36$ DDD 1 & Payne & - & - & 56.0 & 9632 & $1983-$ \\
\hline 360329096450101 & $18 \mathrm{~N}-05 \mathrm{E}-03$ DDD 1 & Payne & - & - & 42.0 & 9634 & $1983-$ \\
\hline 355908096442101 & $18 \mathrm{~N}-05 \mathrm{E}-35 \mathrm{DCC} 1$ & Payne & 322 VMOS & - & - & 9631 & $1977-$ \\
\hline 360927097211001 & $19 \mathrm{~N}-01 \mathrm{~W}-06 \mathrm{BBB} 1$ & Payne & 310WLNG & - & - & 9636 & $1977-$ \\
\hline 360725096521501 & $19 \mathrm{~N}-04 \mathrm{E}-15 \mathrm{CBB} 1$ & Payne & 310 PRMN & 6 & - & 9635 & $1977-$ \\
\hline 345128095441501 & $05 \mathrm{~N}-15 \mathrm{E}-32 \mathrm{DDA} 1$ & Pittsburg & $325 \mathrm{SVNN}$ & - & - & 9637 & $1976-$ \\
\hline 343523096410901 & $01 \mathrm{~N}-06 \mathrm{E}-04 \mathrm{BCB} 1$ & Pontotoc & $371 \mathrm{ABCKL}$ & - & - & 9638 & $1977-$ \\
\hline 350035097031801 & $06 \mathrm{~N}-02 \mathrm{E}-11$ ADA 1 & Pottawatomie & 112TRRCH & - & - & 9639 & $1978-$ \\
\hline 352748097055201 & $11 \mathrm{~N}-02 \mathrm{E}-04 \mathrm{BAA} 1$ & Pottawatomie & - & 3 & 21.5 & 9643 & $1982-$ \\
\hline 352519096545501 & $11 \mathrm{~N}-04 \mathrm{E}-18$ DDC 1 & Pottawatomie & - & - & - & 9642 & $1981-$ \\
\hline 352519096544701 & $11 \mathrm{~N}-04 \mathrm{E}-18$ DDD 1 & Pottawatomie & 112TRRCH & - & - & 9641 & $1981-$ \\
\hline 352420096463601 & $11 \mathrm{~N}-05 \mathrm{E}-21 \mathrm{DCD} 1$ & Pottawatomie & - & 3 & 16.7 & 9670 & $1982_{-}^{-}$ \\
\hline 352509096420601 & $11 \mathrm{~N}-06 \mathrm{E}-19$ AAA 1 & Pottawatomie & - & 3 & 17.1 & 9640 & $1982-$ \\
\hline 341435095350801 & 04S- $16 \mathrm{E}-02$ AAA 1 & Pushmataha & 218ALRS & - & - & 9645 & $1976-$ \\
\hline 341344095373801 & 04S- $16 \mathrm{E}-09$ ABB 1 & Pushmataha & - & - & - & 9644 & $1980-$ \\
\hline 352750099530001 & $11 \mathrm{~N}-25 \mathrm{~W}-06$ ABB 1 & Roger Mills & 121OGLL & 14 & 130 & 2447 & $1979-$ \\
\hline 353206099422201 & $12 \mathrm{~N}-24 \mathrm{~W}-11$ ABC 1 & Roger Mills & 121OGLL & - & - & 9649 & $1980-$ \\
\hline 353100099460801 & $12 \mathrm{~N}-24 \mathrm{~W}-17$ BCC 1 & Roger Mills & 121OGLL & - & 90.0 & 9648 & $1980-$ \\
\hline 353242099471801 & $12 \mathrm{~N}-25 \mathrm{~W}-01$ ADD 1 & Roger Mills & 1210GLL & - & 105 & 9650 & $1980-$ \\
\hline 353044099492601 & $12 \mathrm{~N}-25 \mathrm{~W}-15$ DDA 1 & Roger Mills & 121OGLL & - & 46.0 & 9647 & $1980-$ \\
\hline 352834099533701 & $12 \mathrm{~N}-25 \mathrm{~W}-31 \mathrm{BBD} 1$ & Roger Mills & 1210GLL & - & - & 9335 & $1979-$ \\
\hline 353722099400801 & $13 N-23 W-08$ ABB 1 & Roger Mills & - & - & - & 9328 & $1976-$ \\
\hline 353648099521601 & $13 N-25 W-09$ CBC 1 & Roger Mills & 121OGLL & - & 125 & 9653 & $1981-$ \\
\hline 353440099534001 & $13 \mathrm{~N}-25 \mathrm{~W}-30$ AAC 1 & Roger Mills & 121OGLL & - & 80 & 9651 & $1980-$ \\
\hline 353338099533401 & $13 \mathrm{~N}-25 \mathrm{~W}-31$ ADA 1 & Roger Mills & 110ALVM & 5 & 50.0 & 9326 & 1979 \\
\hline 353712099582001 & $13 \mathrm{~N}-26 \mathrm{~W}-09 \mathrm{BDB} 1$ & Roger Mills & $1210 \mathrm{GLL}$ & 6.62 & 156 & 2632 & $1980-$ \\
\hline 353440099575601 & $13 \mathrm{~N}-26 \mathrm{~W}-28$ AAC 1 & Roger Mills & $1210 \mathrm{GLL}$ & 6.62 & 205 & 2644 & $1980-$ \\
\hline 353854099402401 & $14 N-23 W-32$ BDD 1 & Roger Mills & 110ALVM & 12 & 86.0 & 2687 & $1976-$ \\
\hline 353924099492801 & $14 \mathrm{~N}-25 \mathrm{~W}-26 \mathrm{DCA} 1$ & Roger Mills & $1210 \mathrm{GLL}$ & 5 & 120 & 9657 & 1980 \\
\hline 353904099542201 & $14 \mathrm{~N}-25 \mathrm{~W}-31 \mathrm{BBC} 1$ & Roger Mills & 1210GLL & 6.62 & 80.0 & 9656 & $1980-$ \\
\hline 354702099465501 & $15 \mathrm{~N}-24 \mathrm{~W}-08 \mathrm{CCC} 1$ & Roger Mills & 121OGLL & - & 111 & 9663 & $1980-$ \\
\hline 354651099434101 & $15 \mathrm{~N}-24 \mathrm{~W}-14 \mathrm{BBC} 1$ & Roger Mills & 121OGLL & - & - & 9661 & $1980-$ \\
\hline 354519099465901 & $15 \mathrm{~N}-24 \mathrm{~W}-19$ DDD 1 & Roger Mills & 1210GLL & - & 68 & 9660 & $1980-$ \\
\hline 354340099422501 & $15 \mathrm{~N}-24 \mathrm{~W}-36 \mathrm{CAC} 1$ & Roger Mills & - & - & - & 9658 & $1976-$ \\
\hline 354704099563201 & $15 \mathrm{~N}-26 \mathrm{~W}-11 \mathrm{CCC} 1$ & Roger Mills & 121OGLL & - & 45.7 & 9664 & $1980-$ \\
\hline
\end{tabular}


Table 1.-Ground-water sites included in the mass measurement network-Continued

\begin{tabular}{|c|c|c|c|c|c|c|c|}
\hline Site-ID & Local well number & County & $\begin{array}{c}\text { Aquifer } \\
\text { code }\end{array}$ & $\begin{array}{c}\text { Diameter } \\
\text { of } \\
\text { casing } \\
\text { (in.) } \\
\end{array}$ & $\begin{array}{c}\text { Depth } \\
\text { of well } \\
(\mathrm{ft})\end{array}$ & $\begin{array}{c}\text { OWRB } \\
\text { identifier }\end{array}$ & $\begin{array}{c}\text { Period } \\
\text { of } \\
\text { record }\end{array}$ \\
\hline 354700099552901 & $15 \mathrm{~N}-26 \mathrm{~W}-13$ BBB 1 & Roger Mills & 121OGLL & - & 81.0 & 9662 & $1980-$ \\
\hline 354344099593601 & $15 \mathrm{~N}-26 \mathrm{~W}-32 \mathrm{CCA} 1$ & Roger Mills & 121OGLL & - & 167 & 9659 & 1981- \\
\hline 355047099540501 & $16 \mathrm{~N}-25 \mathrm{~W}-19 \mathrm{CAC} 1$ & Roger Mills & 121OGLL & - & 220 & 9665 & $1980-$ \\
\hline 355219099574501 & $16 \mathrm{~N}-26 \mathrm{~W}-09$ DDD 1 & Roger Mills & 121OGLL & - & - & 9666 & $1980-$ \\
\hline 355122099551601 & $16 \mathrm{~N}-26 \mathrm{~W}-24$ BBA 1 & Roger Mills & 121OGLL & - & 80.0 & 9341 & $1985-$ \\
\hline 355429099502801 & $17 \mathrm{~N}-25 \mathrm{~W}-35 \mathrm{BCA} 1$ & Roger Mills & 121OGLL & - & 一 & 9667 & $1981-$ \\
\hline 362305095420301 & $22 \mathrm{~N}-15 \mathrm{E}-15 \mathrm{CBD} 1$ & Rogers & 121OGLL & - & - & 9668 & 1979 \\
\hline 363306095242201 & $24 \mathrm{~N}-18 \mathrm{E}-20$ AAC 1 & Rogers & 325SNOR & - & - & 9669 & 1979 \\
\hline 352558096271701 & $11 \mathrm{~N}-08 \mathrm{E}-16$ AAD 1 & Seminole & 322 VMOS & - & - & 9671 & 1976- \\
\hline 353117095065201 & $12 \mathrm{~N}-21 \mathrm{E}-18$ AAA 1 & Sequoyah & 110ALVM & - & - & 9672 & $1977-$ \\
\hline 353624094585601 & $13 \mathrm{~N}-22 \mathrm{E}-16 \mathrm{BAD} 1$ & Sequoyah & 326ATCK & - & - & 9673 & 1979 \\
\hline 344050097553101 & $02 \mathrm{~N}-07 \mathrm{~W}-03$ BAB 1 & Stephens & 313RSPG & - & 186 & 9674 & $1976-$ \\
\hline 363346101594001 & $01 N-10 E-09$ CBC 1 & Texas & 121OGLL & 16 & 360 & 800 & $1966-$ \\
\hline 363336101554701 & $01 \mathrm{~N}-10 \mathrm{E}-12 \mathrm{DCD} 1$ & Texas & 121OGLL & 16 & 352 & 9691 & $1966-$ \\
\hline 363318101583801 & $01 \mathrm{~N}-10 \mathrm{E}-15$ BCB 1 & Texas & 121OGLL & 16 & 382 & 803 & $1965-$ \\
\hline 363037102004100 & $01 \mathrm{~N}-10 \mathrm{E}-32 \mathrm{CBA} 1$ & Texas & 1210GLL & - & 414 & 9676 & $1966-$ \\
\hline 363451101542001 & $01 \mathrm{~N}-11 \mathrm{E}-05 \mathrm{CBB} 1$ & Texas & 121OGLL & 16 & 309 & 812 & $1966-$ \\
\hline 363118101511001 & $01 \mathrm{~N}-11 \mathrm{E}-22 \mathrm{DDC} 1$ & Texas & 121OGLL & 4 & 122 & 9682 & $1966-$ \\
\hline 363118101510001 & $01 \mathrm{~N}-11 \mathrm{E}-26 \mathrm{CBB} 1$ & Texas & 121OGLL & - & 316 & 818 & 1963- \\
\hline 363336101470901 & $01 \mathrm{~N}-12 \mathrm{E}-08$ DCD 1 & Texas & 121OGLL & 5 & 104 & 9690 & $1966-$ \\
\hline 363459101370001 & $01 \mathrm{~N}-13 \mathrm{E}-01$ BCB 2 & Texas & 121OGLL & 16 & 310 & 840 & $1964-$ \\
\hline 363405101390401 & $01 N-13 E-10$ BCB 1 & Texas & 121OGLL & 16 & 402 & 9695 & 1964- \\
\hline 363118101373101 & $01 N-13 E-26$ DBB 1 & Texas & 121OGLL & 5 & 324 & 9680 & $1966-$ \\
\hline 363359101321201 & $01 \mathrm{~N}-14 \mathrm{E}-10$ BDD 1 & Texas & 121OGLL & 5 & 211 & 9694 & $1966-$ \\
\hline 363032101355101 & $01 N-14 E-31$ CBB 1 & Texas & 121OGLL & - & - & 9385 & $1966-$ \\
\hline 363314101242901 & $01 \mathrm{~N}-15 \mathrm{E}-14$ ACA 1 & Texas & 121OGLL & 6.63 & 181 & 868 & $1980-$ \\
\hline 363238101292801 & $01 \mathrm{~N}-15 \mathrm{E}-19 \mathrm{BBB} 1$ & Texas & 121OGLL & 16 & 321 & 871 & $1965-$ \\
\hline 363209101283201 & $01 \mathrm{~N}-15 \mathrm{E}-19$ DAA 1 & Texas & 121OGLL & 16 & 365 & 9684 & $1964-$ \\
\hline 363107101261501 & $01 \mathrm{~N}-15 \mathrm{E}-27 \mathrm{CCB} 1$ & Texas & 121OGLL & 6 & 133 & 9678 & $1966-$ \\
\hline 363027101282301 & $01 \mathrm{~N}-15 \mathrm{E}-32 \mathrm{CBB} 1$ & Texas & 121 OGLL & 16 & 333 & 9675 & $1966-$ \\
\hline 363512101203801 & $01 \mathrm{~N}-16 \mathrm{E}-04 \mathrm{BAB} 1$ & Texas & 121OGLL & 16 & 260 & 9699 & $1980-$ \\
\hline 363202101213301 & $01 \mathrm{~N}-16 \mathrm{E}-20 \mathrm{CAD} 1$ & Texas & 121OGLL & 16 & 400 & 9683 & 1980 \\
\hline 363439101110701 & $01 \mathrm{~N}-17 \mathrm{E}-01 \mathrm{CBC} 1$ & Texas & 121OGLL & 16 & 475 & 911 & $1966-$ \\
\hline 363338101131801 & $01 N-17 E-10$ CCC 1 & Texas & 121OGLL & 4 & 180 & 9692 & $1966-$ \\
\hline 363211101161101 & $01 \mathrm{~N}-17 \mathrm{E}-19 \mathrm{CCC} 1$ & Texas & 121OGLL & 16 & 365 & 9685 & $1966-$ \\
\hline 363115101160001 & $01 \mathrm{~N}-17 \mathrm{E}-30 \mathrm{DBB} 1$ & Texas & 121OGLL & 2 & 363 & 9679 & $1970-$ \\
\hline 363242101042301 & $01 \mathrm{~N}-18 \mathrm{E}-13 \mathrm{CDC} 1$ & Texas & 110ALVM & 20 & 27.0 & 9687 & $1966-$ \\
\hline 363048101064601 & $01 \mathrm{~N}-18 \mathrm{E}-34 \mathrm{BBA} 1$ & Texas & 121OGLL & 5 & 80.0 & 9677 & $1966-$ \\
\hline 362958101220201 & 01S-16E-06 AAA 1 & Texas & 121OGLL & - & - & 9386 & $1966-$ \\
\hline 363742102002301 & $02 N-10 E-20$ BBD 1 & Texas & 121OGLL & 16 & 300 & 9710 & $1967-$ \\
\hline
\end{tabular}


Table 1.-Ground-water sites included in the mass measurement network-Continued

\begin{tabular}{|c|c|c|c|c|c|c|c|}
\hline Site-ID & Local well number & County & $\begin{array}{c}\text { Aquifer } \\
\text { code }\end{array}$ & $\begin{array}{c}\text { Diameter } \\
\text { of } \\
\text { casing } \\
\text { (in.) } \\
\end{array}$ & $\begin{array}{l}\text { Depth } \\
\text { of well } \\
\text { (ft) }\end{array}$ & $\begin{array}{c}\text { OWRB } \\
\text { identifier }\end{array}$ & $\begin{array}{c}\text { Period } \\
\text { of } \\
\text { record }\end{array}$ \\
\hline 363648101584901 & $02 \mathrm{~N}-10 \mathrm{E}-28 \mathrm{BCB} 1$ & Texas & 121OGLL & 6 & 204 & 9706 & $1966-$ \\
\hline 363534101521001 & $02 \mathrm{~N}-11 \mathrm{E}-34 \mathrm{CCB} 1$ & Texas & $121 \mathrm{OGLL}$ & 16 & 300 & 949 & $1966-$ \\
\hline 363632101423901 & $02 \mathrm{~N}-12 \mathrm{E}-25 \mathrm{DBB} 1$ & Texas & $1210 G L L$ & 16 & 332 & 953 & $1955-$ \\
\hline 363604101462601 & $02 \mathrm{~N}-12 \mathrm{E}-33 \mathrm{BAB} 1$ & Texas & 110ALVM & 16 & 60.0 & 9702 & $1955-$ \\
\hline 363819101363001 & $02 \mathrm{~N}-13 \mathrm{E}-13 \mathrm{CAA} 1$ & Texas & 121OGLL & 16 & 300 & 9713 & $1966-$ \\
\hline 363843101401201 & $02 \mathrm{~N}-13 \mathrm{E}-16 \mathrm{BBB} 1$ & Texas & 121OGLL & 16 & 320 & 9715 & $1958-$ \\
\hline 363520101411701 & $02 \mathrm{~N}-13 \mathrm{E}-32 \mathrm{CCC} 1$ & Texas & 121OGLL & 16 & 384 & 988 & $1963-$ \\
\hline 363909101312301 & $02 \mathrm{~N}-14 \mathrm{E}-11 \mathrm{CBA} 1$ & Texas & 121OGLL & 16 & 342 & 9719 & $1966-$ \\
\hline 363718101313001 & $02 \mathrm{~N}-14 \mathrm{E}-23 \mathrm{CBB} 2$ & Texas & 121OGLL & 2 & 287 & 9708 & $1970-$ \\
\hline 363716101303101 & $02 \mathrm{~N}-14 \mathrm{E}-24 \mathrm{CBC} 1$ & Texas & 1210GLL & 16 & 360 & 9707 & $1980-$ \\
\hline 363911101271401 & 02N-15E-09 BCB 1 & Texas & $1210 \mathrm{OLL}$ & 16 & 408 & 9720 & 1955- \\
\hline 363843101254501 & $02 \mathrm{~N}-15 \mathrm{E}-15 \mathrm{BAA} 1$ & Texas & 121OGLL & 2 & 410 & 9714 & $1970-$ \\
\hline 364003101201901 & $02 \mathrm{~N}-16 \mathrm{E}-04 \mathrm{DBA} 1$ & Texas & 121OGLL & 16 & 435 & 9725 & $1964-$ \\
\hline 363927101225701 & $02 \mathrm{~N}-16 \mathrm{E}-07 \mathrm{BBB} 1$ & Texas & 121OGLL & 16 & 480 & 1106 & $1964-$ \\
\hline 363929101210701 & $02 \mathrm{~N}-16 \mathrm{E}-08$ AAA 1 & Texas & $1210 G L L$ & - & - & 1111 & $1966-$ \\
\hline 363816101184201 & $02 \mathrm{~N}-16 \mathrm{E}-14 \mathrm{CBB} 1$ & Texas & 1210GLL & 16 & 455 & 1120 & $1964-$ \\
\hline 363848101163101 & $02 \mathrm{~N}-17 \mathrm{E}-07 \mathrm{CCC} 1$ & Texas & 121OGLL & 16 & 473 & 1135 & $1965-$ \\
\hline 363932101064401 & $02 \mathrm{~N}-18 \mathrm{E}-03$ BDC 1 & Texas & 110ALVM & 6 & 33.0 & 9723 & $1967-$ \\
\hline 363938101090101 & $02 \mathrm{~N}-18 \mathrm{E}-08 \mathrm{BAD} 1$ & Texas & 121OGLL & 6 & 117 & 9724 & $1968-$ \\
\hline 363907101051001 & $02 \mathrm{~N}-18 \mathrm{E}-11$ DBB 1 & Texas & 121OGLL & - & 94.0 & 9718 & $1966-$ \\
\hline 363758101051301 & $02 \mathrm{~N}-18 \mathrm{E}-14$ DCD 1 & Texas & $1210 G L L$ & 16 & 312 & 9711 & $1960-$ \\
\hline 363727101044101 & $02 \mathrm{~N}-18 \mathrm{E}-24 \mathrm{BCC} 1$ & Texas & 121OGLL & 2 & 321 & 9709 & $1969-$ \\
\hline 363636101064801 & $02 \mathrm{~N}-18 \mathrm{E}-27 \mathrm{BCC} 1$ & Texas & 121OGLL & 16 & 293 & 1156 & 1959 \\
\hline 363629101100401 & $02 \mathrm{~N}-18 \mathrm{E}-30 \mathrm{CBB} 1$ & Texas & 121OGLL & 16 & 482 & 9703 & $1956-$ \\
\hline 363904101031501 & $02 N-19 \mathrm{E}-07 \mathrm{CAA} 1$ & Texas & 121OGLL & - & 88.0 & 9717 & $1966-$ \\
\hline 364447101573301 & $03 \mathrm{~N}-10 \mathrm{E}-11$ BBB 2 & Texas & 231DCKM & 6 & 194 & 9733 & $1966-$ \\
\hline 364220102014101 & $03 N-10 E-19$ CDC 1 & Texas & 231DCKM & 16 & 270 & 1175 & $1966-$ \\
\hline 364305101562401 & $03 \mathrm{~N}-10 \mathrm{E}-24 \mathrm{BBB} 1$ & Texas & $1210 G L L$ & 16 & 220 & 1178 & $1956-$ \\
\hline 364325101552501 & $03 \mathrm{~N}-11 \mathrm{E}-18 \mathrm{CBC} 1$ & Texas & 121OGLL & 16 & 200 & 9730 & $1956-$ \\
\hline 364459101373601 & 03N-13E-02 CDD 1 & Texas & 121OGLL & 3 & 73.0 & 9734 & 1966-- \\
\hline 364301101175401 & $03 \mathrm{~N}-16 \mathrm{E}-23$ AAB 1 & Texas & 121OGLL & 6 & 122 & 9728 & $1966-$ \\
\hline 364202101195501 & $03 \mathrm{~N}-16 \mathrm{E}-28$ AAD 1 & Texas & 121OGLL & 4 & 148 & 9726 & $1966-$ \\
\hline 364334101111101 & $03 \mathrm{~N}-17 \mathrm{E}-13 \mathrm{CBB} 1$ & Texas & 1210GLL & 6 & - & 9732 & $1966-$ \\
\hline 365033101524702 & 04N-11E-04 DBD 1 & Texas & 231DCKM & - & 386 & 9754 & $1982-$ \\
\hline 365006101520801 & $04 \mathrm{~N}-11 \mathrm{E}-10 \mathrm{BBB} 1$ & Texas & 231DCKM & - & - & 9750 & $1966-$ \\
\hline 365026101321102 & 04N-14E-03 DBB 1 & Texas & 121OGLL & 16 & 350 & 1316 & $1980-$ \\
\hline 365046101345101 & $04 \mathrm{~N}-14 \mathrm{E}-05 \mathrm{BBC} 1$ & Texas & $1210 \mathrm{GLL}$ & 5 & 167.50 & 9755 & $1966-$ \\
\hline 364851101303901 & 04N-14E-14 ADD 1 & Texas & 121OGLL & 16 & 273 & 9746 & $1966-$ \\
\hline 364939101262101 & $04 \mathrm{~N}-15 \mathrm{E}-09$ ADD 1 & Texas & 121OGLL & 16 & 540 & 1335 & $1966-$ \\
\hline 364945101244101 & $04 \mathrm{~N}-15 \mathrm{E}-11 \mathrm{BDA} 1$ & Texas & 121 OGLL & 16 & 381 & 1337 & $1966-$ \\
\hline
\end{tabular}


Table 1.-Ground-water sites included in the mass measurement network-Continued

\begin{tabular}{|c|c|c|c|c|c|c|c|}
\hline Site-ID & Local well number & County & $\begin{array}{c}\text { Aquifer } \\
\text { code }\end{array}$ & $\begin{array}{c}\text { Diameter } \\
\text { of } \\
\text { casing } \\
\text { (in.) } \\
\end{array}$ & $\begin{array}{c}\text { Depth } \\
\text { of well } \\
(\mathrm{ft})\end{array}$ & $\begin{array}{c}\text { OWRB } \\
\text { identifier }\end{array}$ & $\begin{array}{c}\text { Period } \\
\text { of } \\
\text { record }\end{array}$ \\
\hline 364844101255801 & $04 \mathrm{~N}-15 \mathrm{E}-15 \mathrm{CAB} 1$ & Texas & 121OGLL & 16 & 440 & 1340 & $1966-$ \\
\hline 364703101233501 & $04 \mathrm{~N}-15 \mathrm{E}-25$ DBB 1 & Texas & 121OGLL & 16 & 468 & 1354 & $1966-$ \\
\hline 364705101264701 & $04 \mathrm{~N}-15 \mathrm{E}-28$ ACC 1 & Texas & 121OGLL & 16 & 510 & 1356 & $1966-$ \\
\hline 365028101215901 & $04 \mathrm{~N}-16 \mathrm{E}-05 \mathrm{CCB} 1$ & Texas & 121OGLL & 16 & 627 & 1362 & $1966-$ \\
\hline 364858101213301 & $04 \mathrm{~N}-16 \mathrm{E}-17$ BAD 1 & Texas & 121OGLL & 16 & 497 & 9747 & $1966-$ \\
\hline 364740101190501 & $04 \mathrm{~N}-16 \mathrm{E}-22 \mathrm{DCB} 1$ & Texas & 121OGLL & 16 & 264 & 1375 & $1966-$ \\
\hline 364724101215601 & $04 \mathrm{~N}-16 \mathrm{E}-29$ BBB 1 & Texas & 121OGLL & 16 & 495 & 1383 & $1966-$ \\
\hline 365015101132301 & 04N-17E-03 CBC 1 & Texas & 121OGLL & - & 486 & 1387 & $1966-$ \\
\hline 364822101121101 & $04 \mathrm{~N}-17 \mathrm{E}-14 \mathrm{CCD} 1$ & Texas & 121OGLL & 16 & 402 & 9744 & 1966- \\
\hline 364817101133101 & $04 \mathrm{~N}-17 \mathrm{E}-21$ AAA 1 & Texas & 121OGLL & 16 & 515 & 1408 & $1964-$ \\
\hline 364810101112501 & $04 \mathrm{~N}-17 \mathrm{E}-23$ AAA 1 & Texas & 121OGLL & 16 & 567 & 1412 & $1966-$ \\
\hline 364614101133001 & 04N-17E-33 ADD 1 & Texas & 121OGLL & 16 & 491 & 1421 & $1966-$ \\
\hline 364658101044301 & $04 \mathrm{~N}-18 \mathrm{E}-25 \mathrm{CBB} 1$ & Texas & 121OGLL & 16 & 355 & 9736 & $1966-$ \\
\hline 364716101053601 & $04 \mathrm{~N}-18 \mathrm{E}-26 \mathrm{BCA} 1$ & Texas & 121OGLL & 16 & 350 & 1434 & $1966-$ \\
\hline 364734100571301 & $04 \mathrm{~N}-20 \mathrm{E}-19 \mathrm{CBB} 1$ & Texas & 121OGLL & 5 & 120 & 9060 & $1968-$ \\
\hline 365407101530001 & $05 \mathrm{~N}-11 \mathrm{E}-16$ BCB 1 & Texas & 121OGLL & 16 & 334 & 9767 & $1966-$ \\
\hline 365607101481101 & 05N-12E-06 BAA 1 & Texas & 121OGLL & - & 320 & 1531 & 1968- \\
\hline 365422101462601 & $05 \mathrm{~N}-12 \mathrm{E}-16$ BBB 1 & Texas & 121OGLL & 16 & 350 & 1536 & $1966-$ \\
\hline 365325101454001 & $05 \mathrm{~N}-12 \mathrm{E}-21 \mathrm{AAB} 1$ & Texas & 121OGLL & 16 & 253 & 1540 & $1966-$ \\
\hline 365313101451801 & $05 \mathrm{~N}-12 \mathrm{E}-22 \mathrm{CBB} 1$ & Texas & 121OGLL & 16 & 272 & 1541 & $1982-$ \\
\hline 365546101363301 & 05N-13E-01 CBA 1 & Texas & 121OGLL & 16 & 380 & 9779 & $1966-$ \\
\hline 365509101405501 & $05 \mathrm{~N}-13 \mathrm{E}-08 \mathrm{BBB} 1$ & Texas & 121OGLL & 16 & 300 & 1554 & $1966-$ \\
\hline 365358101371201 & 05N-13E-14 DBB 1 & Texas & 121OGLL & 16 & 350 & 9766 & $1966-$ \\
\hline 365335101294001 & $05 \mathrm{~N}-14 \mathrm{E}-01$ ABB 1 & Texas & 121OGLL & - & - & 9762 & $1966-$ \\
\hline 365451101321901 & $05 \mathrm{~N}-14 \mathrm{E}-10 \mathrm{CBB} 1$ & Texas & 121OGLL & 16 & 485 & 1573 & $1966-$ \\
\hline 365130101350001 & $05 \mathrm{~N}-14 \mathrm{E}-31 \mathrm{ACC} 1$ & Texas & 121OGLL & 16 & 367 & 1584 & $1964-$ \\
\hline 365428101273901 & 05N-15E-08 CDD 1 & Texas & 121OGLL & 16 & 446 & 9771 & $1954-$ \\
\hline 365354101244401 & 05N-15E-14 CBA 1 & Texas & 121OGLL & 16 & 501 & 1604 & $1964-$ \\
\hline 365300101271001 & $05 \mathrm{~N}-15 \mathrm{E}-20$ DAB 1 & Texas & 121OGLL & - & 365 & 9759 & $1966-$ \\
\hline 365336101214701 & $05 \mathrm{~N}-16 \mathrm{E}-18$ DDC 2 & Texas & 121OGLL & 7 & 197 & 9763 & $1966-$ \\
\hline 365552101094901 & 05N-17E-01 ADA 1 & Texas & 121OGLL & - & 116 & 9780 & $1966-$ \\
\hline 365437101130301 & 05N-17E-09 DDA 1 & Texas & 121OGLL & 4 & 125 & 9772 & $1966-$ \\
\hline 365427101111501 & $05 \mathrm{~N}-17 \mathrm{E}-11$ DCC 1 & Texas & 121OGLL & 6 & 153 & 9770 & $1966-$ \\
\hline 365358101145301 & 05N-17E-17 CBA 1 & Texas & 121OGLL & 16 & 515 & 1675 & $1966-$ \\
\hline 365234101122001 & $05 \mathrm{~N}-17 \mathrm{E}-27$ ABC 1 & Texas & 121OGLL & 18 & 343 & 1679 & $1966-$ \\
\hline 365541101044901 & $05 \mathrm{~N}-18 \mathrm{E}-02 \mathrm{DBB} 1$ & Texas & 121OGLL & - & - & 9777 & $1966-$ \\
\hline 365539101002301 & 05N-19E-04 DBA 1 & Texas & 121OGLL & - & 510 & 1705 & $1966-$ \\
\hline 365513101023601 & $05 \mathrm{~N}-19 \mathrm{E}-07$ ABB 1 & Texas & - & 16 & 595 & 9774 & $1980-$ \\
\hline 365421100571201 & $05 N-19 E-13$ ABB 1 & Texas & - & 16 & 536 & 1713 & $1980-$ \\
\hline 365208101010601 & 05N-19E-29 DAA 1 & Texas & 121OGLL & 2 & 567 & 9757 & $1970-$ \\
\hline
\end{tabular}


Table 1.-Ground-water sites included in the mass measurement network-Continued

\begin{tabular}{|c|c|c|c|c|c|c|c|}
\hline Site-ID & Local well number & County & $\begin{array}{c}\text { Aquifer } \\
\text { code }\end{array}$ & $\begin{array}{c}\text { Diameter } \\
\text { of } \\
\text { casing } \\
\text { (in.) }\end{array}$ & $\begin{array}{l}\text { Depth } \\
\text { of well } \\
\text { (ft) }\end{array}$ & $\begin{array}{l}\text { OWRB } \\
\text { identifier }\end{array}$ & $\begin{array}{c}\text { Period } \\
\text { of } \\
\text { record }\end{array}$ \\
\hline 365636101554301 & $06 \mathrm{~N}-10 \mathrm{E}-36 \mathrm{DBB} 1$ & Texas & 121OGLL & 16 & 400 & 1745 & $1966-$ \\
\hline 365903101540201 & $06 \mathrm{~N}-11 \mathrm{E}-17 \mathrm{CBC} 1$ & Texas & 121OGLL & - & 357 & 9799 & $1967-$ \\
\hline 365739101504801 & $06 \mathrm{~N}-11 \mathrm{E}-26 \mathrm{BCB} 2$ & Texas & 121OGLL & 16 & 423 & 1771 & $1966-$ \\
\hline 365810101400201 & $06 \mathrm{~N}-13 \mathrm{E}-20 \mathrm{DDA} 1$ & Texas & 121OGLL & 16 & 440 & 1826 & $1966-$ \\
\hline 365730101420601 & $06 \mathrm{~N}-13 \mathrm{E}-30 \mathrm{CBB} 1$ & Texas & 121OGLL & 16 & 434 & 1838 & $1966-$ \\
\hline 365825101330001 & $06 \mathrm{~N}-14 \mathrm{E}-21 \mathrm{ACB} 1$ & Texas & 121OGLL & - & 542 & 1855 & $1966-$ \\
\hline 365633101311501 & $06 \mathrm{~N}-14 \mathrm{E}-35 \mathrm{CBB} 1$ & Texas & 121OGLL & 16 & 379 & 1874 & $1966-$ \\
\hline 365735101283501 & $06 \mathrm{~N}-15 \mathrm{E}-30$ ACB 1 & Texas & 121OGLL & - & - & 9792 & $1966-$ \\
\hline 365649101270001 & $06 \mathrm{~N}-15 \mathrm{E}-33 \mathrm{BBC} 1$ & Texas & 121OGLL & 16 & 395 & 9786 & $1980-$ \\
\hline 365750101195501 & $06 \mathrm{~N}-16 \mathrm{E}-27$ ACC 1 & Texas & 121OGLL & 2 & 605 & 9794 & $1970-$ \\
\hline 365606101112001 & $06 \mathrm{~N}-17 \mathrm{E}-14 \mathrm{DBB} 1$ & Texas & 121OGLL & 16 & 435 & 1895 & $1966-$ \\
\hline 365809101114701 & $06 \mathrm{~N}-17 \mathrm{E}-23 \mathrm{CBC} 1$ & Texas & 121OGLL & - & 145 & 9795 & $1966-$ \\
\hline 365706101134001 & $06 \mathrm{~N}-17 \mathrm{E}-28 \mathrm{CCD} 1$ & Texas & 121OGLL & 5 & 149 & 9788 & $1966-$ \\
\hline 365616101115701 & $06 \mathrm{~N}-17 \mathrm{E}-34 \mathrm{DDD} 1$ & Texas & 121OGLL & - & 118 & 9783 & $1966-$ \\
\hline 365704101070301 & $06 \mathrm{~N}-18 \mathrm{E}-28 \mathrm{CDD} 1$ & Texas & 121OGLL & 6 & 133 & 9787 & $1966-$ \\
\hline 365730101084101 & $06 \mathrm{~N}-18 \mathrm{E}-30$ ADD 1 & Texas & 121OGLL & - & 125 & 9790 & $1966-$ \\
\hline 365857100595601 & $06 \mathrm{~N}-19 \mathrm{E}-15 \mathrm{CCC} 1$ & Texas & 121OGLL & 16 & 437 & 9798 & $1966-$ \\
\hline 343122099013201 & $01 \mathrm{~N}-17 \mathrm{~W}-30$ DCC 1 & Tillman & 112TRRCH & - & 28.0 & 9829 & $1974-$ \\
\hline 343511099025101 & $01 \mathrm{~N}-18 \mathrm{~W}-01 \mathrm{CAB} 1$ & Tillman & 112TRRCH & - & 42.0 & 9834 & $1953-$ \\
\hline 343419099041001 & $01 \mathrm{~N}-18 \mathrm{~W}-11 \mathrm{CBB} 1$ & Tillman & - & - & - & 9833 & $1977-$ \\
\hline 343313099052901 & $01 \mathrm{~N}-18 \mathrm{~W}-16 \mathrm{DDB} 1$ & Tillman & 112TRRCH & - & - & 9832 & 1974- \\
\hline 343122099062401 & $01 \mathrm{~N}-18 \mathrm{~W}-29 \mathrm{DDD} 1$ & Tillman & - & - & - & 9830 & $1947-$ \\
\hline 343300099083801 & $01 \mathrm{~N}-19 \mathrm{~W}-24 \mathrm{AAB} 1$ & Tillman & 112TRRCH & - & 54.0 & 9831 & $1975-$ \\
\hline 342957099015701 & $01 \mathrm{~S}-17 \mathrm{~W}-06$ DBB 1 & Tillman & - & - & 58.0 & 9827 & $1984-$ \\
\hline 342938099053001 & 01S-18W-04 DCD 1 & Tillman & 112TRRCH & - & 46.0 & 9826 & $1970-$ \\
\hline 342845099043501 & $01 \mathrm{~S}-18 \mathrm{~W}-10$ DCC 1 & Tillman & 112TRRCH & - & 58.0 & 9824 & $1974-$ \\
\hline 342727099072101 & 01S-18W-19 ADD 1 & Tillman & 112TRRCH & - & 50.0 & 9822 & $1970-$ \\
\hline 342700099040301 & $01 \mathrm{~S}-18 \mathrm{~W}-23 \mathrm{CCC} 1$ & Tillman & 112TRRCH & - & 58.0 & 9821 & $1974-$ \\
\hline 342654099054601 & $01 \mathrm{~S}-18 \mathrm{~W}-28$ BAA 1 & Tillman & - & - & - & 9819 & $1977-$ \\
\hline 342615099072101 & 01S- $18 \mathrm{~W}-30 \mathrm{DDA} 1$ & Tillman & 112TRRCH & - & 50.0 & 9817 & $1981-$ \\
\hline 342601099051401 & $01 \mathrm{~S}-18 \mathrm{~W}-33$ AAA 1 & Tillman & 112TRRCH & - & 50.0 & 9816 & $1968-$ \\
\hline 342542099030001 & $01 \mathrm{~S}-18 \mathrm{~W}-36$ BCC 1 & Tillman & - & - & - & 9815 & $1974-$ \\
\hline 343017099103001 & $01 \mathrm{~S}-19 \mathrm{~W}-03$ AAD 1 & Tillman & 112TRRCH & $\ldots$ & 46.0 & 9828 & 1969 \\
\hline 342931099122001 & 01S-19W-09 BBA 1 & Tillman & 112TRRCH & - & 38.0 & 9825 & 1974- \\
\hline 342806099092701 & 01S-19W-14 DAD 1 & Tillman & 112TRRCH & - & 43.0 & 9823 & $1974-$ \\
\hline 342628099082401 & $01 \mathrm{~S}-19 \mathrm{~W}-25$ DAA 1 & Tillman & - & - & - & 9818 & $1944-$ \\
\hline 342654099105301 & $01 \mathrm{~S}-19 \mathrm{~W}-27$ ABB 1 & Tillman & 112TRRCH & $\ldots$ & 47.0 & 9820 & 1975- \\
\hline 342535099091901 & 01S-19W-36 CBB 1 & Tillman & 112TRRCH & - & 54.0 & 9814 & $1969-$ \\
\hline 343735099010801 & $02 \mathrm{~N}-17 \mathrm{~W}-19 \mathrm{DDA} 1$ & Tillman & 112TRRCH & - & 47.0 & 9835 & $1977-$ \\
\hline 342430099053801 & 02S-18W-04 DCB 2 & Tillman & 112TRRCH & - & 65.0 & 9812 & $1975-$ \\
\hline
\end{tabular}


Table 1.-Ground-water sites included in the mass measurement network-Continued

\begin{tabular}{|c|c|c|c|c|c|c|c|}
\hline Site-ID & Local well number & County & $\begin{array}{c}\text { Aquifer } \\
\text { code }\end{array}$ & $\begin{array}{c}\text { Diameter } \\
\text { of } \\
\text { casing } \\
\text { (in.) } \\
\end{array}$ & $\begin{array}{c}\text { Depth } \\
\text { of well } \\
\text { (ft) }\end{array}$ & $\begin{array}{c}\text { OWRB } \\
\text { identifier }\end{array}$ & $\begin{array}{c}\text { Period } \\
\text { of } \\
\text { record }\end{array}$ \\
\hline 342245099050701 & 02S-18W-15 CCB 1 & Tillman & 112TRRCH & - & 62.0 & 9810 & $1970-$ \\
\hline 342443099134701 & 02S-19W-06 DAB 1 & Tillman & 110ALVM & - & - & 9813 & 1974- \\
\hline 342309099085501 & 02S-19W-13 BC 1 & Tillman & 112TRRCH & 14 & 70.0 & 9811 & $1974-$ \\
\hline 341718099102201 & 02S-19W-23 ВBВ 1 & Tillman & - & - & $\ldots$ & 9806 & 1984- \\
\hline 342001099083201 & 02S-19W-36 DBC 1 & Tillman & - & - & - & 9809 & 1984- \\
\hline 341559099003901 & 03S-17W-29 CAB 1 & Tillman & - & - & 18.0 & 9805 & $1970-$ \\
\hline 341539099015701 & 03S-17W-30 CCC 1 & Tillman & - & - & 32.0 & 9804 & $1983-$ \\
\hline 341955099051401 & 03S-18W-04 AAA 1 & Tillman & - & - & - & 9808 & $1974-$ \\
\hline 341723099052401 & 03S-18W-21 BA 1 & Tillman & 112TRRCH & 16 & 46.0 & 9807 & 1974- \\
\hline 341447099062501 & 03S-18W-32 DDC 2 & Tillman & 112TRRCH & - & 70.0 & 9803 & $1969-$ \\
\hline 341342099030001 & $04 \mathrm{~S}-18 \mathrm{~W}-12$ BBC 1 & Tillman & 112TRRCH & - & 64.0 & 9801 & $1981-$ \\
\hline 341441099084701 & 04S-19W-01 ABB 1 & Tillman & 112TRRCH & - & - & 9802 & 1981- \\
\hline 355914095534701 & $17 \mathrm{~N}-13 \mathrm{E}-02 \mathrm{BAB} 1$ & Tulsa & 110TRRCL & - & 37.00 & 9837 & $1988-$ \\
\hline 355210095224401 & $16 \mathrm{~N}-18 \mathrm{E}-15$ AAA 1 & Wagoner & 110ALVM & - & - & 9838 & $1976-$ \\
\hline 363819095523901 & $25 \mathrm{~N}-13 \mathrm{E}-23$ DAA 1 & Washington & 110ALVM & - & - & 9839 & $1979-$ \\
\hline 364919095523101 & $27 \mathrm{~N}-13 \mathrm{E}-13 \mathrm{CBB} 1$ & Washington & 323DEWY & - & - & 9840 & $1977-$ \\
\hline 365557095521501 & $28 \mathrm{~N}-13 \mathrm{E}-01 \mathrm{CDC} 1$ & Washington & 323WANN & - & - & 9841 & $1979-$ \\
\hline 351630098432401 & 09N-14W-07 BAA 1 & Washita & - & 6 & 52.2 & 9843 & $1957-$ \\
\hline 351308098395701 & $09 \mathrm{~N}-14 \mathrm{~W}-27$ DCD 1 & Washita & 313RSPG & 14 & 312 & 9842 & $1955-$ \\
\hline 352238098384301 & $10 \mathrm{~N}-14 \mathrm{~W}-02 \mathrm{AAB}$ & Washita & 313RSPG & 18 & 395 & 9194 & $1989-$ \\
\hline 352229098384601 & $10 \mathrm{~N}-14 \mathrm{~W}-02$ AAC 1 & Washita & 313RSPG & - & 352 & 9846 & $1979-$ \\
\hline 351939098394101 & $10 \mathrm{~N}-14 \mathrm{~W}-22 \mathrm{ADD} 1$ & Washita & 313RSPG & - & - & 9844 & $1979-$ \\
\hline 352203098472201 & $10 \mathrm{~N}-15 \mathrm{~W}-04$ DBD 1 & Washita & - & - & - & 9845 & $1980-$ \\
\hline 362933098350501 & $23 N-13 W-03$ CCC 1 & Woods & 110CMTA & - & 73 & 9849 & $1983-$ \\
\hline 362755098371301 & $23 \mathrm{~N}-13 \mathrm{~W}-17 \mathrm{CCB} 1$ & Woods & 110CMTA & - & 70 & 9848 & $1975-$ \\
\hline 363446098334401 & $24 \mathrm{~N}-13 \mathrm{~W}-02 \mathrm{CDC} 1$ & Woods & 110CMTA & 6 & 55 & 9853 & 1983- \\
\hline 363446098352901 & $24 \mathrm{~N}-13 \mathrm{~W}-04$ DCD 1 & Woods & 110CMTA & 6 & 32 & 9854 & 1983-- \\
\hline 363209098402601 & $24 \mathrm{~N}-14 \mathrm{~W}-23 \mathrm{CCC} 1$ & Woods & 110CMTA & 4.5 & 60 & 9852 & 1974- \\
\hline 363150098444301 & $24 \mathrm{~N}-14 \mathrm{~W}-30$ BCB 1 & Woods & 110CMTA & 5 & 59 & 9851 & $1983-$ \\
\hline 363045098403401 & $24 \mathrm{~N}-14 \mathrm{~W}-34$ DAA 1 & Woods & 110CMTA & 5 & 75 & 9850 & $1979-$ \\
\hline 363446098514101 & $24 \mathrm{~N}-16 \mathrm{~W}-01$ DCC 1 & Woods & 110CMTA & - & 80 & 9855 & 1983- \\
\hline 363916098353601 & $25 \mathrm{~N}-13 \mathrm{~W}-10 \mathrm{CCC} 1$ & Woods & 110CMTA & - & 35 & 9859 & 1983- \\
\hline 363751098395501 & $25 \mathrm{~N}-14 \mathrm{~W}-24 \mathrm{CBB} 1$ & Woods & 110CMTA & - & 14 & 9858 & $1983-$ \\
\hline 363658098502601 & $25 \mathrm{~N}-15 \mathrm{~W}-29 \mathrm{CAB} 1$ & Woods & 110CMTA & - & 82 & 9857 & $1975-$ \\
\hline 363547098505001 & $25 \mathrm{~N}-15 \mathrm{~W}-31$ DDD 1 & Woods & 110CMTA & 5 & 68 & 9856 & $1983-$ \\
\hline 364422098374601 & $26 \mathrm{~N}-13 \mathrm{~W}-17$ BBB 1 & Woods & 110CMTA & - & 76 & 9861 & $1983-$ \\
\hline 364330098401901 & $26 \mathrm{~N}-14 \mathrm{~W}-23$ ABA 1 & Woods & 110CMTA & - & 44 & 9860 & $1983-$ \\
\hline 364613098391401 & $27 \mathrm{~N}-14 \mathrm{~W}-36$ DCD 1 & Woods & $110 \mathrm{CMTA}$ & - & 48 & 9862 & $1983-$ \\
\hline 361447099105501 & $20 \mathrm{~N}-19 \mathrm{~W}-01$ BAA 1 & Woodward & - & - & - & 9390 & $1977-$ \\
\hline 361221099182601 & $20 \mathrm{~N}-20 \mathrm{~W}-14 \mathrm{CCA} 1$ & Woodward & 1210GLL & 5 & 180 & 5275 & $1980-$ \\
\hline
\end{tabular}


Table 1.-Ground-water sites included in the mass measurement network-Continued

\begin{tabular}{|c|c|c|c|c|c|c|c|}
\hline Site-ID & Local well number & County & $\begin{array}{c}\text { Aquifer } \\
\text { code }\end{array}$ & $\begin{array}{c}\text { Diameter } \\
\text { of } \\
\text { casing } \\
\text { (in.) } \\
\end{array}$ & $\begin{array}{c}\text { Depth } \\
\text { of well } \\
\text { (ft) }\end{array}$ & $\begin{array}{c}\text { OWRB } \\
\text { identifier }\end{array}$ & $\begin{array}{c}\text { Period } \\
\text { of } \\
\text { record }\end{array}$ \\
\hline 361128099210601 & $20 \mathrm{~N}-20 \mathrm{~W}-20$ DCA 1 & Woodward & 121OGLL & 5 & 85 & 9864 & $1980-$ \\
\hline 361340099252201 & $20 \mathrm{~N}-21 \mathrm{~W}-10$ ACA 1 & Woodward & 121OGLL & 5 & 310 & 9867 & $1980-$ \\
\hline 361432099301001 & $20 \mathrm{~N}-22 \mathrm{~W}-01 \mathrm{BCA} 1$ & Woodward & 121OGLL & 5 & 285 & 9869 & $1980-$ \\
\hline 361146099395001 & $20 \mathrm{~N}-22 \mathrm{~W}-19$ ADD 1 & Wooodward & 121OGLL & - & 144 & 9865 & $1980-$ \\
\hline 361006099293201 & $20 \mathrm{~N}-22 \mathrm{~W}-36$ ADD 1 & Woodward & $121 \mathrm{PLCN}$ & 1 & 402 & 9863 & $1957-$ \\
\hline 361737099024301 & $21 \mathrm{~N}-17 \mathrm{~W}-17 \mathrm{CDB} 1$ & Woodward & 112TRRCH & 5 & 82.0 & 9872 & $1978-$ \\
\hline 361610099070901 & $21 \mathrm{~N}-18 \mathrm{~W}-27$ BCB 1 & Woodward & 110ALVM & 6 & 54.0 & 9871 & $1977-$ \\
\hline 361856099112401 & $21 \mathrm{~N}-19 \mathrm{~W}-12$ BBD 1 & Woodward & $110 \mathrm{ALVM}$ & 16 & 30.0 & 9876 & $1956-$ \\
\hline 361949099192601 & $21 \mathrm{~N}-20 \mathrm{~W}-03$ ABD 1 & Woodward & 121OGLL & - & 134 & 9877 & $1980-$ \\
\hline 361833099192201 & $21 \mathrm{~N}-20 \mathrm{~W}-10 \mathrm{DBD} 1$ & Woodward & 121OGLL & 5 & 58 & 5385 & $1980-$ \\
\hline 361605099253201 & $21 \mathrm{~N}-21 \mathrm{~W}-27 \mathrm{DAA} 1$ & Woodward & 121OGLL & - & - & 9870 & $1980-$ \\
\hline 361748099334101 & $21 \mathrm{~N}-22 \mathrm{~W}-16 \mathrm{CAA} 1$ & Woodward & 121OGLL & - & - & 9873 & $1980-$ \\
\hline 362325099091901 & $22 \mathrm{~N}-18 \mathrm{~W}-17$ BBB 1 & Woodward & 112TRRCH & 6 & 41.0 & 9884 & $1978-$ \\
\hline 362002099081801 & $22 \mathrm{~N}-18 \mathrm{~W}-33 \mathrm{CCC} 1$ & Woodward & - & .75 & 62 & 9878 & $1977-$ \\
\hline 362144099174101 & $22 \mathrm{~N}-20 \mathrm{~W}-25 \mathrm{BBA} 1$ & Woodward & 313RSPG & 5 & 10.0 & 9880 & $1952-$ \\
\hline 362147099224701 & $22 \mathrm{~N}-21 \mathrm{~W}-24 \mathrm{CCD} 1$ & Woodward & 121OGLL & 3 & 125 & 9881 & $1980-$ \\
\hline 362101099264701 & $22 \mathrm{~N}-21 \mathrm{~W}-28 \mathrm{DDB} 1$ & Woodward & 121OGLL & 5 & 240 & 5467 & $1980-$ \\
\hline 362429099301101 & $22 \mathrm{~N}-22 \mathrm{~W}-01 \mathrm{DCA} 1$ & Woodward & 121OGLL & - & 346 & 9886 & $1982-$ \\
\hline 362502099311401 & $22 \mathrm{~N}-22 \mathrm{~W}-02$ ABA 1 & Woodward & 121PLCN & 12 & 69.0 & 9887 & $1978-$ \\
\hline 362350099341501 & $22 \mathrm{~N}-22 \mathrm{~W}-08$ DAD 1 & Woodward & 121OGLL & 12 & 204 & 9885 & $1980-$ \\
\hline 362149099361501 & $22 \mathrm{~N}-22 \mathrm{~W}-19 \mathrm{CCC} 1$ & Woodward & - & - & 77.0 & 9882 & $1956-$ \\
\hline 362229099295801 & $22 \mathrm{~N}-22 \mathrm{~W}-24$ AAB 1 & Woodward & - & - & - & 9883 & $1983-$ \\
\hline 362818099103001 & $23 \mathrm{~N}-19 \mathrm{~W}-13 \mathrm{ADD} 1$ & Woodward & 112TRRCH & 12 & 100 & 5514 & $1978-$ \\
\hline 362748099134401 & $23 \mathrm{~N}-19 \mathrm{~W}-21$ AAA 1 & Woodward & 112TRRCH & 12 & 80.0 & 5523 & $1978-$ \\
\hline 362737099125101 & $23 \mathrm{~N}-19 \mathrm{~W}-22$ AAC 1 & Woodward & - & 16 & 80.0 & 5524 & $1977-$ \\
\hline 363020099220201 & $23 \mathrm{~N}-20 \mathrm{~W}-05 \mathrm{BBA} 1$ & Woodward & - & 6 & 40.0 & 9896 & $1977-$ \\
\hline 362728099220201 & $23 \mathrm{~N}-20 \mathrm{~W}-20 \mathrm{BCA} 1$ & Woodward & $112 \mathrm{TRRCH}$ & 5 & 39.0 & 9891 & $1978-$ \\
\hline 362650099254401 & $23 \mathrm{~N}-21 \mathrm{~W}-27$ AAB 1 & Woodward & 121OGLL & - & 62 & 9888 & $1980-$ \\
\hline 362942099320301 & $23 \mathrm{~N}-22 \mathrm{~W}-03$ DDA 1 & Woodward & 110ALVM & - & 45.9 & 9895 & $1980-$ \\
\hline 362659099322201 & $23 \mathrm{~N}-22 \mathrm{~W}-22$ DCD 1 & Woodward & 121OGLL & 12 & 41.0 & 9890 & $1978-$ \\
\hline 362658099321801 & $23 \mathrm{~N}-22 \mathrm{~W}-22$ DDB 1 & Woodward & 121OGLL & - & 51.0 & 5552 & $1980-$ \\
\hline 362534099344501 & $23 \mathrm{~N}-22 \mathrm{~W}-32$ DBD 1 & Woodward & 110ALVM & - & 76 & 5558 & $1981-$ \\
\hline 363300099232001 & $24 \mathrm{~N}-20 \mathrm{~W}-18 \mathrm{CCC} 1$ & Woodward & - & - & 51.2 & 9898 & $1978-$ \\
\hline 363023099231901 & $24 \mathrm{~N}-20 \mathrm{~W}-31 \mathrm{CCC} 1$ & Woodward & 112TRRCH & - & 70.0 & 9897 & $1978-$ \\
\hline 363308099245801 & $24 \mathrm{~N}-21 \mathrm{~W}-14 \mathrm{CDA} 1$ & Woodward & $112 \mathrm{TRRCH}$ & - & 44.0 & 9899 & $1978-$ \\
\hline 363534099331101 & $24 \mathrm{~N}-22 \mathrm{~W}-04$ AAA 1 & Woodward & 121OGLL & - & 72.0 & 9900 & $1980-$ \\
\hline
\end{tabular}




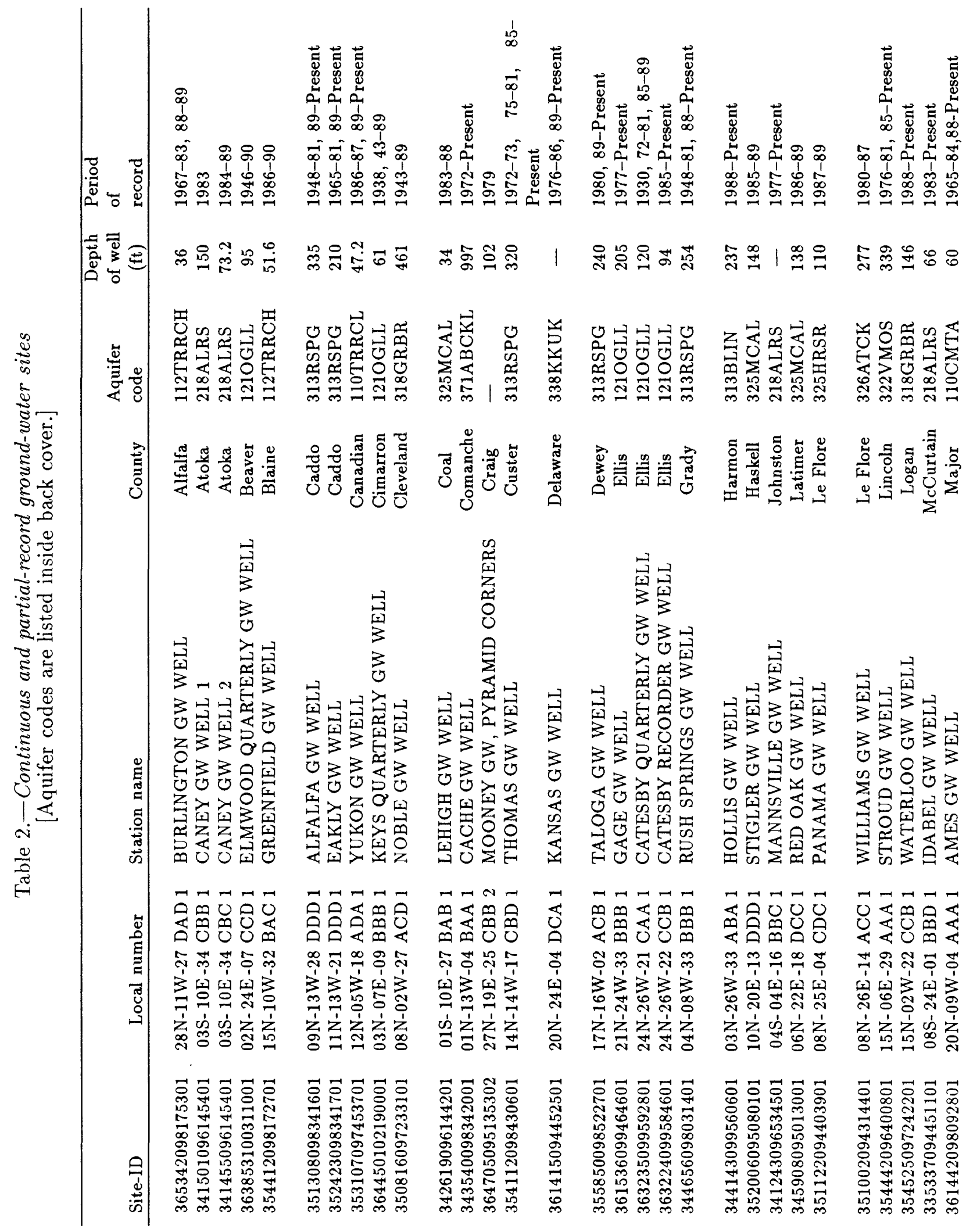




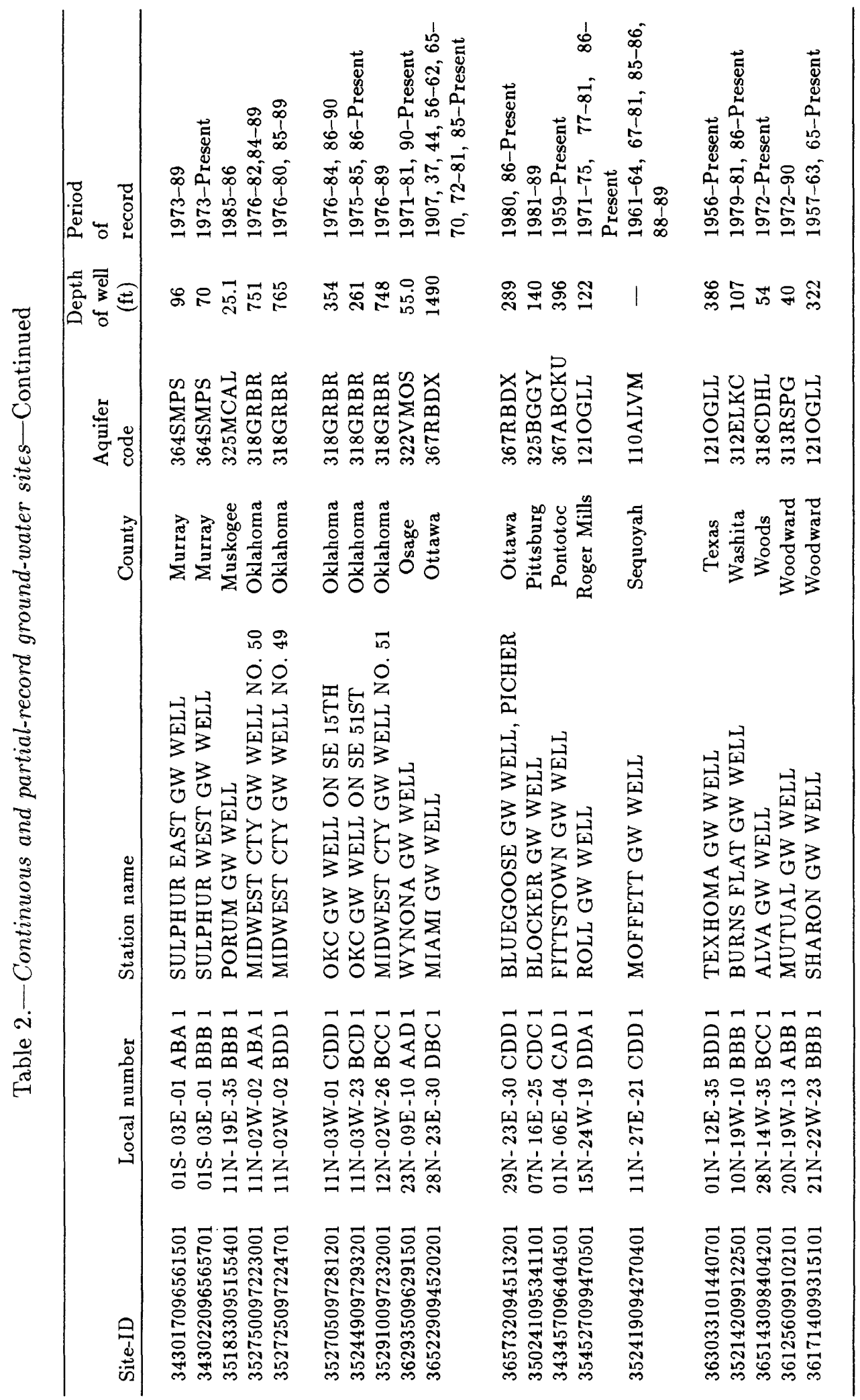




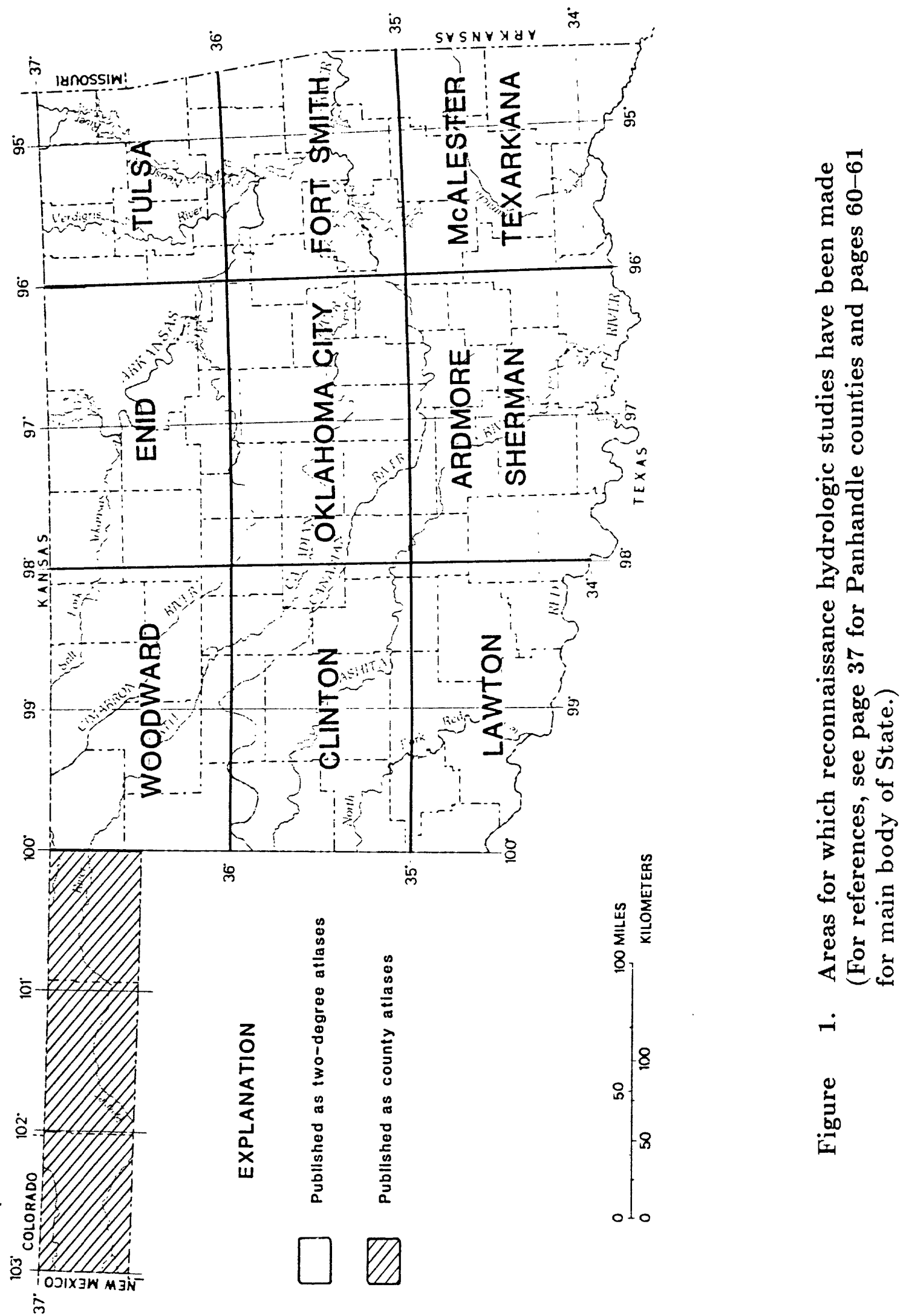




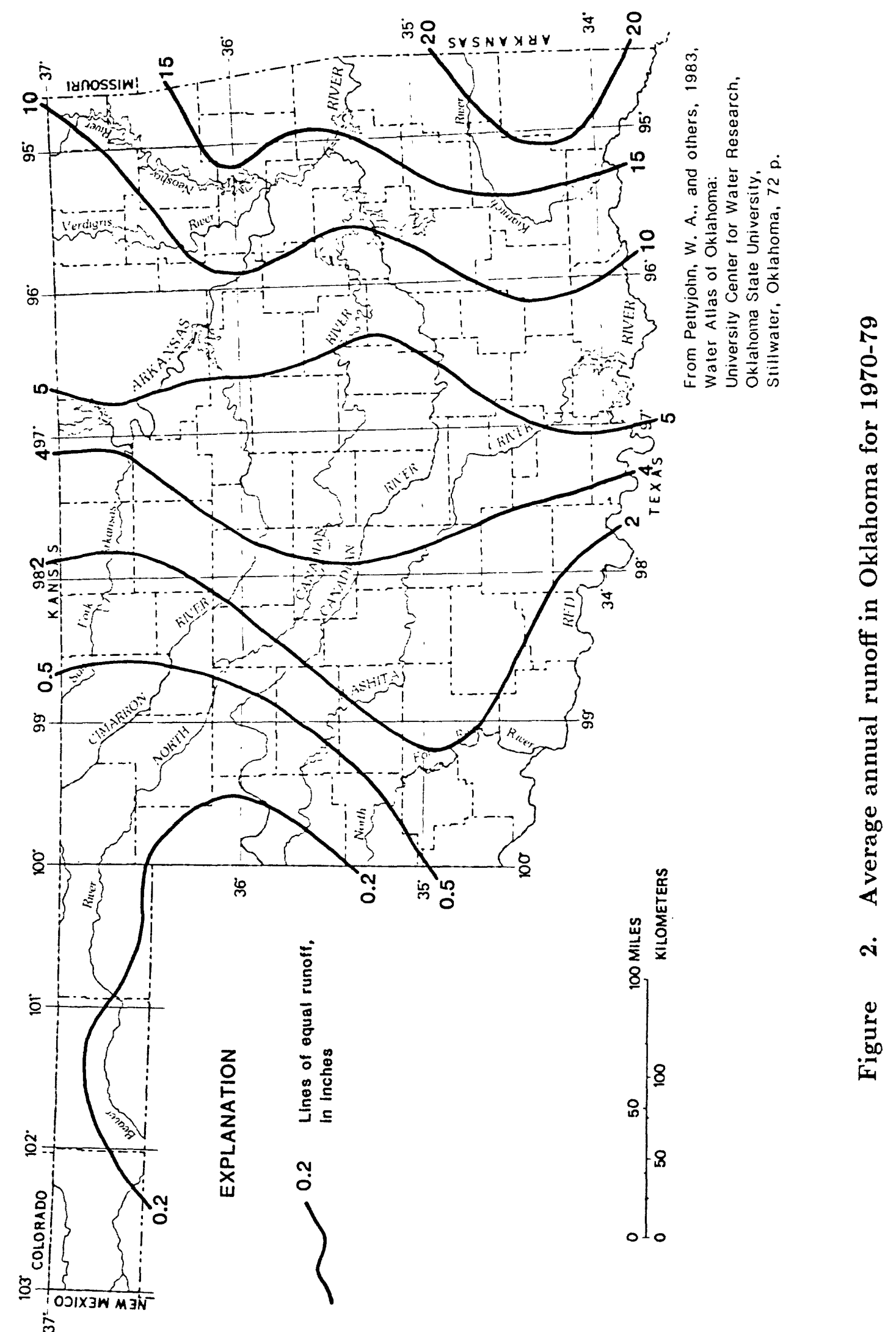




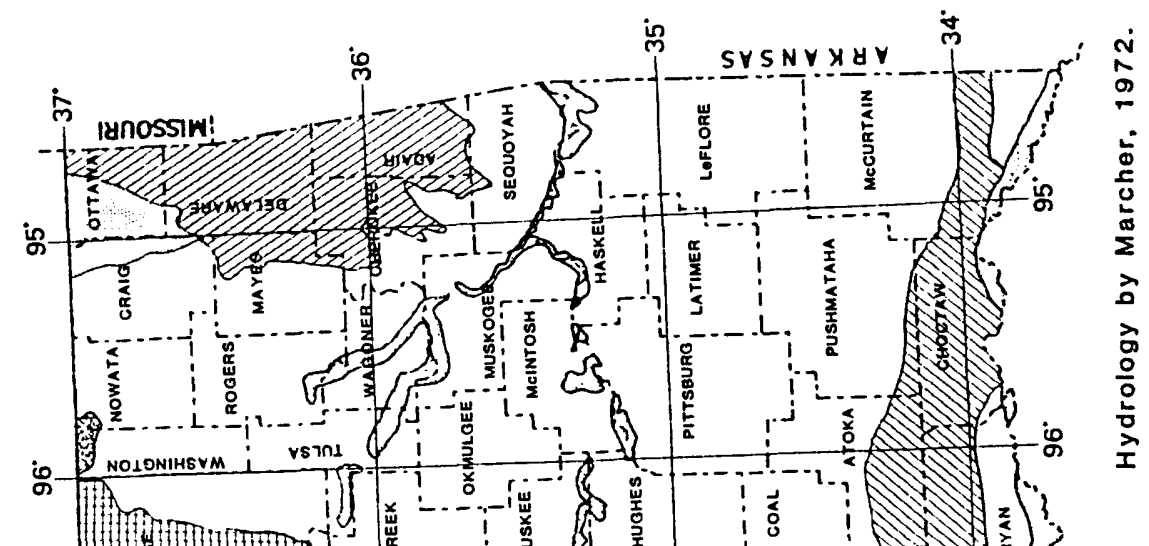

हี
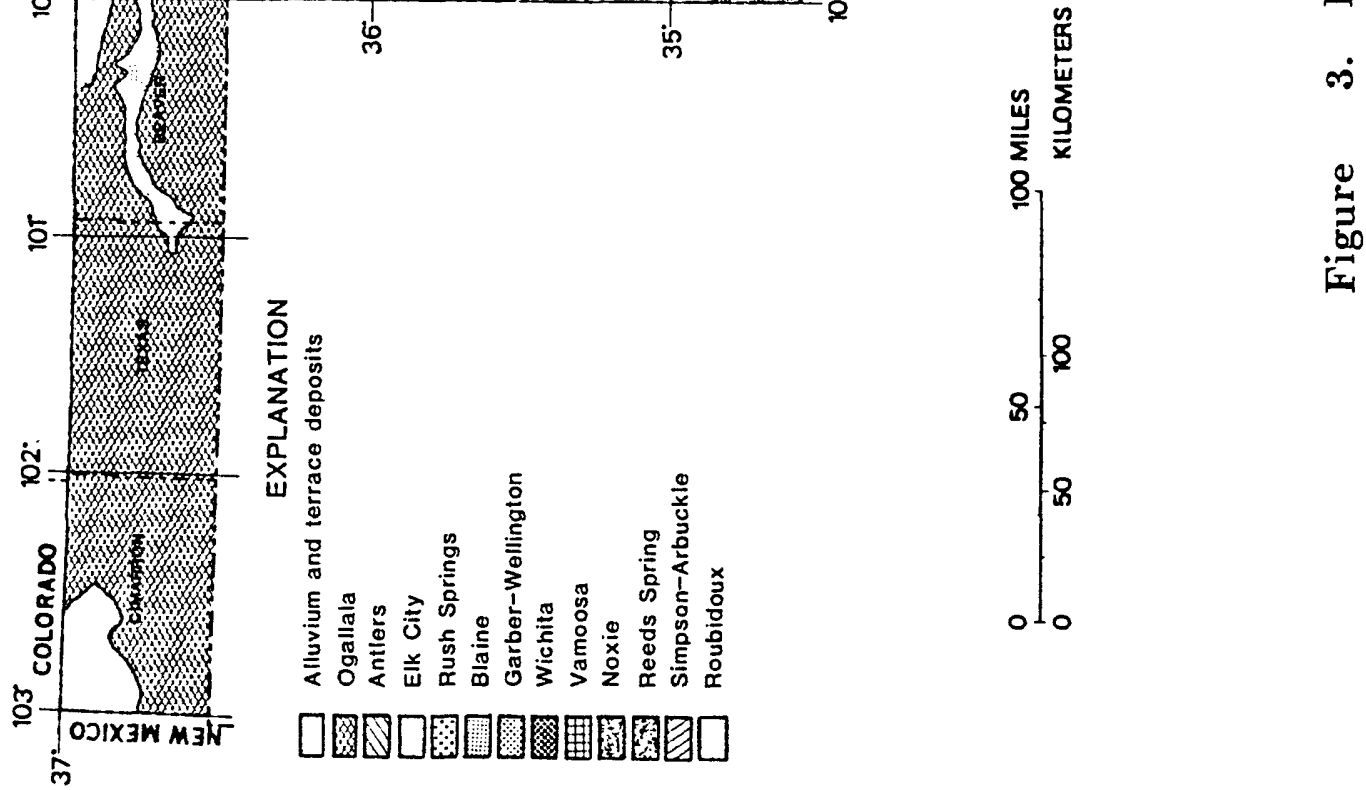


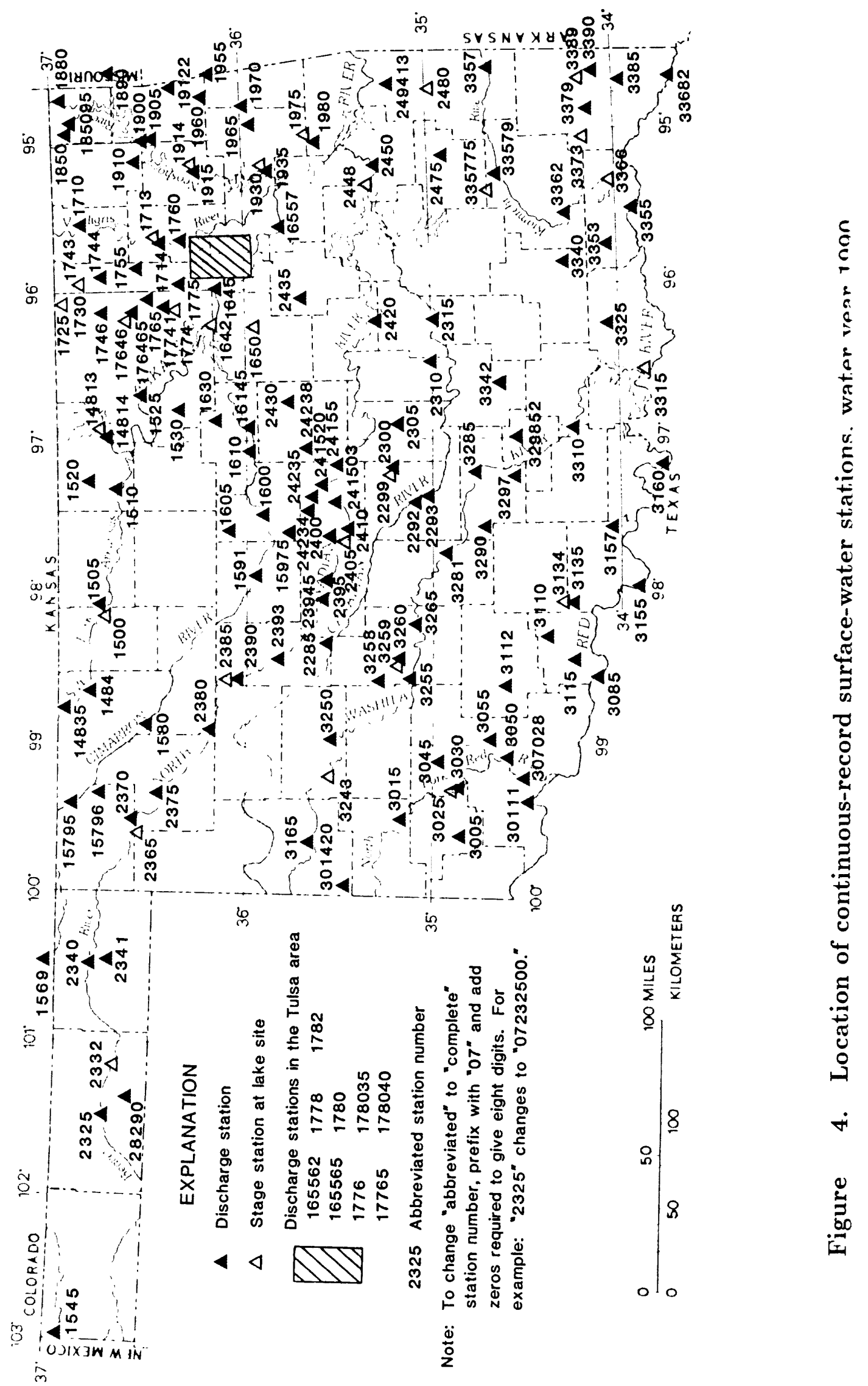




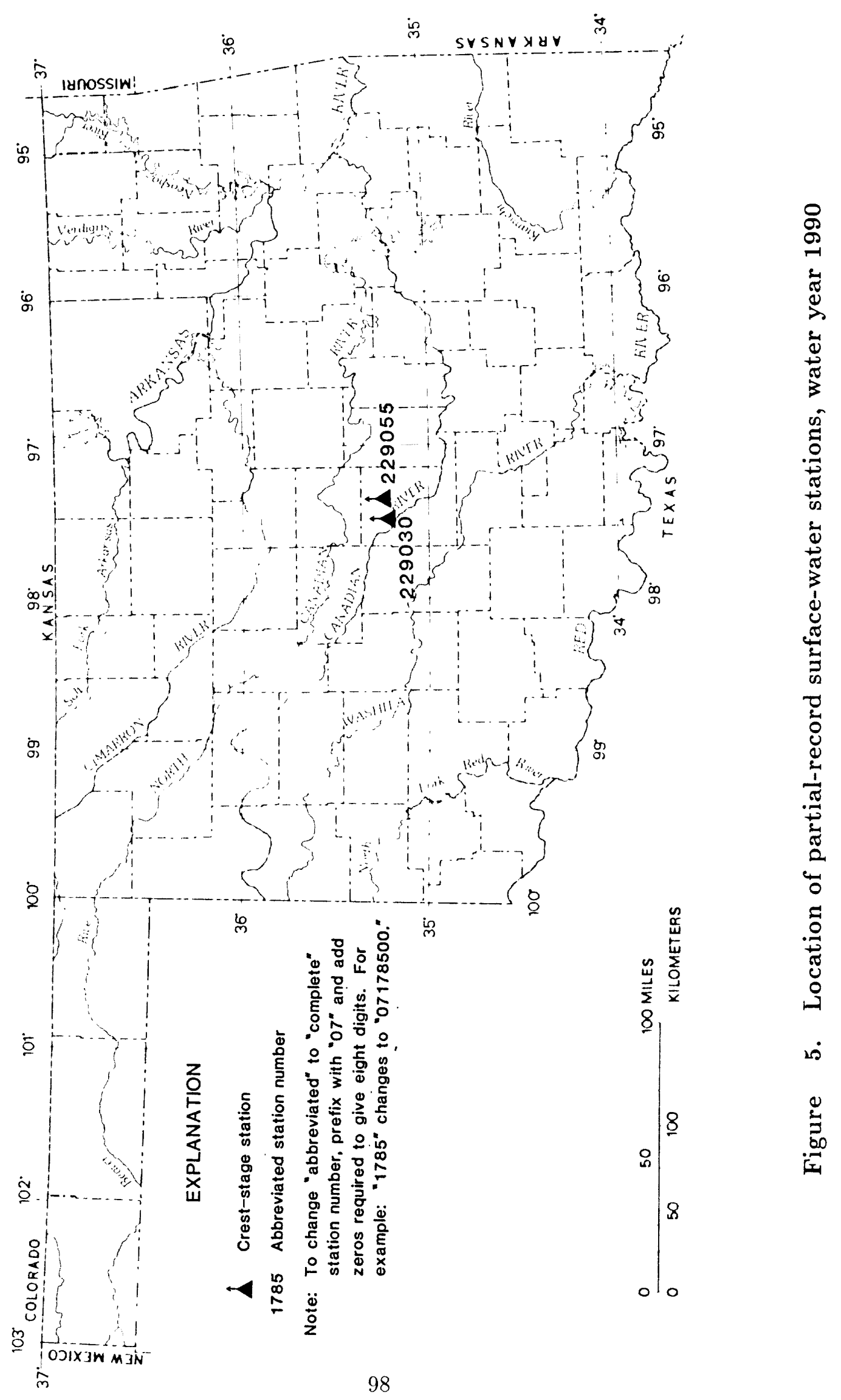




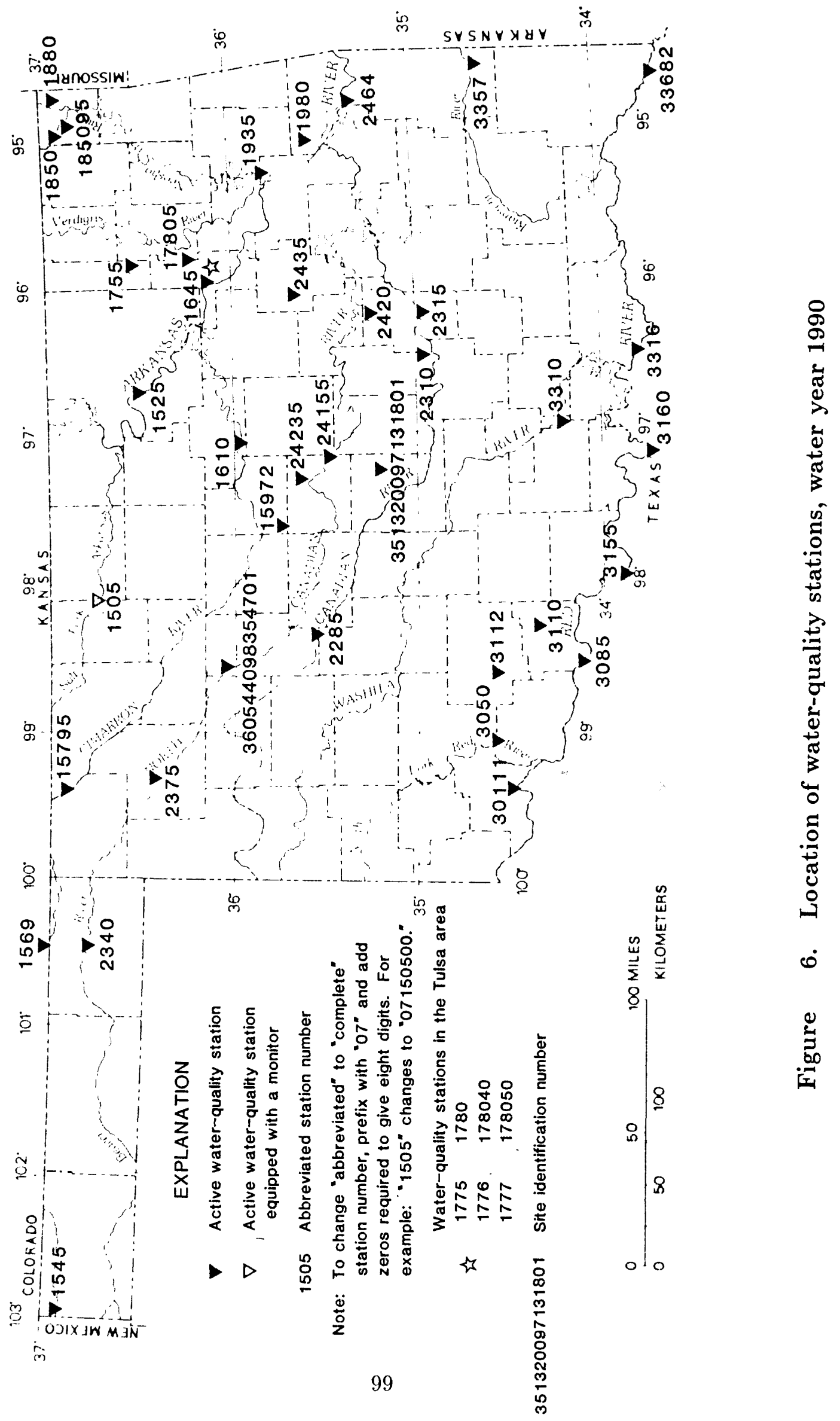




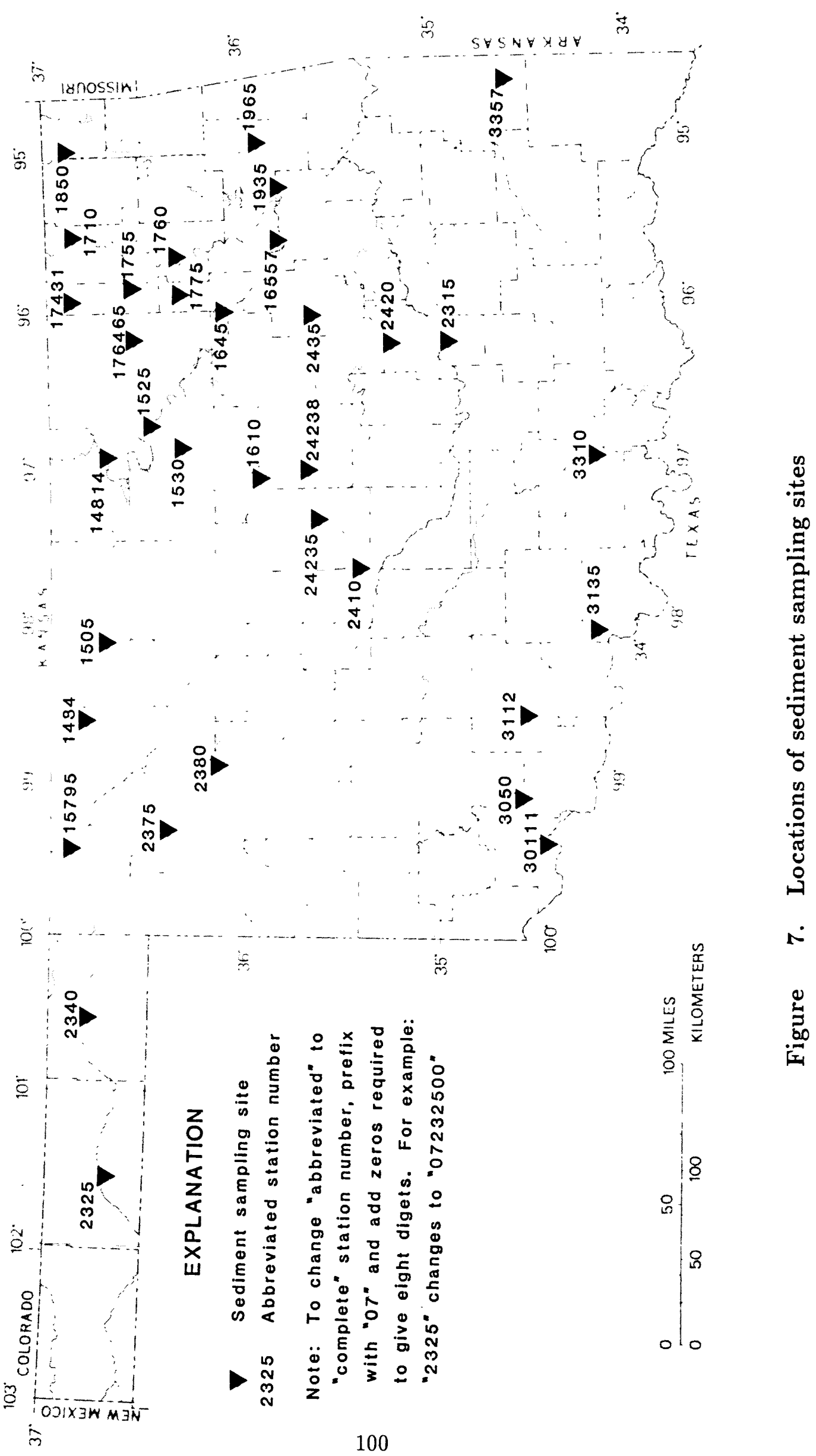




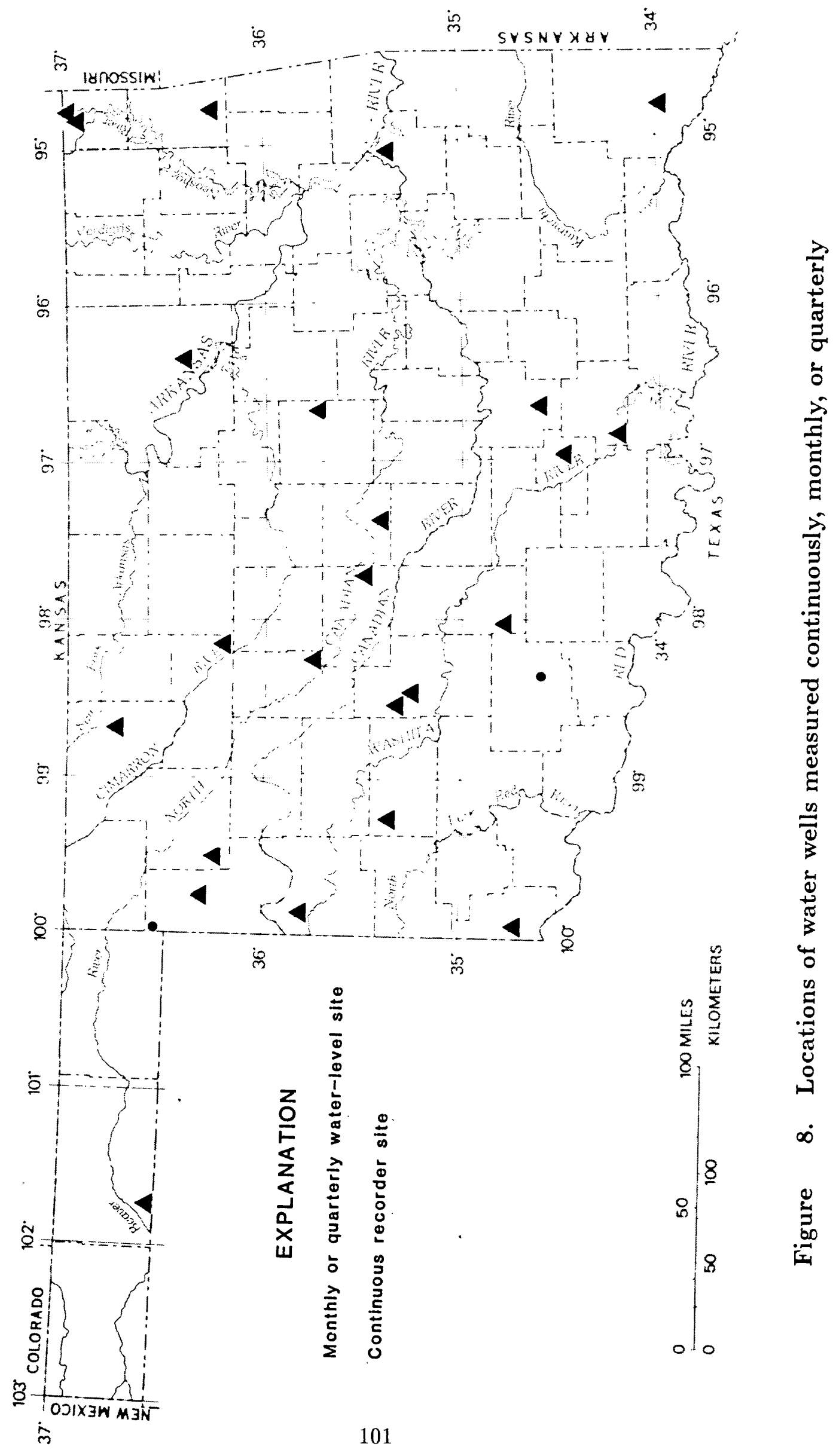




\section{OKLAHOMA AQUIFER CODES}

\begin{tabular}{|c|c|c|}
\hline 110ALVM & - & Quaternary alluvium \\
\hline 110CMTA & - & Cimarron terrace and alluvial aquifer \\
\hline 110EFRT & - & Elm Fork-Red River terrace aquifer \\
\hline 110TRRCL & 一 & Terrace deposits, low \\
\hline 112DUNE & - & Dune sand \\
\hline 112TRRCH & - & Terrace deposits, high \\
\hline 121OGLL & - & Ogallala Formation \\
\hline 121PLCN & - & Pliocene series \\
\hline $211 \mathrm{DKCN}$ & 一 & Dakota Formation-Cheyenne Sandstone \\
\hline $217 C Y N N$ & 一 & Cheyenne Sandstone \\
\hline 218ALRS & 一 & Antlers Sandstone \\
\hline 221EXTR & - & Exeter Sandstone \\
\hline $221 \mathrm{MRSN}$ & 一 & Morrison Formation \\
\hline 231DCKM & - & Dockum Group \\
\hline 310PRMN & - & Permian series \\
\hline 310WLNG & - & Wellington Formation \\
\hline $312 \mathrm{ELKC}$ & - & Elk City Member of Quartermaster Formation \\
\hline 313BLIN & - & Blaine Gypsum \\
\hline 313DGCK & - & Dog Creek Shale \\
\hline 313RSPG & - & Rush Springs Formation \\
\hline 313VVCR & - & Van Vactor Member of Blaine Formation \\
\hline $317 \mathrm{GBWG}$ & - & Garber-Wellington aquifer \\
\hline 318CDHL & - & Cedar Hills Sandstone Member \\
\hline 318GRBR & - & Garber Sandstone \\
\hline $318 \mathrm{WCHT}$ & - & Wichita Group \\
\hline $322 \mathrm{VMOS}$ & - & Vamoosa Formation \\
\hline 323CFVL & - & Coffeyville Formation \\
\hline 323DEWY & - & Dewey Limestone \\
\hline 323IOLA & - & Iola Limestone \\
\hline 323 WANN & - & Wann Formation \\
\hline 325BGGY & - & Boggy Shale \\
\hline 325HRSR & - & Hartshorne Sandstone \\
\hline $325 \mathrm{MCAL}$ & - & McAlester Shale \\
\hline 325SNOR & - & Senora Formation \\
\hline $325 \mathrm{SVNN}$ & - & Savanna Sandstone \\
\hline 325 TRMN & 一 & Thurman Sandstone \\
\hline 326ATCK & - & Atoka Formation \\
\hline $331 \mathrm{BOON}$ & - & Boone Formation \\
\hline 331PTKN & - & Pitkin Limestone \\
\hline $338 \mathrm{KKUK}$ & - & Keokuk Limestone \\
\hline 364SMPS & - & Simpson Group \\
\hline $367 \mathrm{ABCKU}$ & - & Arbuckle Limestone, upper \\
\hline 367RBDX & - & Roubidoux Formation \\
\hline 371ABCKL & - & Arbuckle Limestone, lower \\
\hline
\end{tabular}

